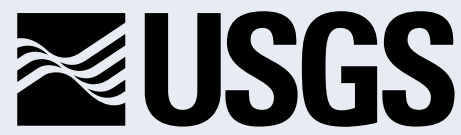

science for a changing world

Prepared in cooperation with the city of Aberdeen

\title{
Conceptual and Numerical Models of the Glacial Aquifer System North of Aberdeen, South Dakota
}

Scientific Investigations Report 2012-5183 
Front cover. Elm River north of Aberdeen, South Dakota. 


\section{Conceptual and Numerical Models of the Glacial Aquifer System North of Aberdeen, South Dakota}

By Katrina A. Marini, Galen K. Hoogestraat, Katherine R. Aurand, and

Larry D. Putnam

Prepared in cooperation with the city of Aberdeen

Scientific Investigations Report 2012-5183 


\section{U.S. Department of the Interior \\ KEN SALAZAR, Secretary \\ U.S. Geological Survey \\ Marcia K. McNutt, Director}

\section{U.S. Geological Survey, Reston, Virginia: 2012}

For more information on the USGS - the Federal source for science about the Earth, its natural and living resources, natural hazards, and the environment, visit http://www.usgs.gov or call 1-888-ASK-USGS.

For an overview of USGS information products, including maps, imagery, and publications, visit http://www.usgs.gov/pubprod

To order this and other USGS information products, visit http://store.usgs.gov

Any use of trade, firm, or product names is for descriptive purposes only and does not imply endorsement by the U.S. Government.

Although this information product, for the most part, is in the public domain, it also may contain copyrighted materials as noted in the text. Permission to reproduce copyrighted items must be secured from the copyright owner.

Suggested citation:

Marini, K.A., Hoogestraat, G.K., Aurand, K.R., and Putnam, L.D., 2012, Conceptual and numerical models of the glacial aquifer system north of Aberdeen, South Dakota: U.S. Geological Survey Scientific Investigations Report 2012-5183, 98 p. with appendixes. 


\section{Contents}

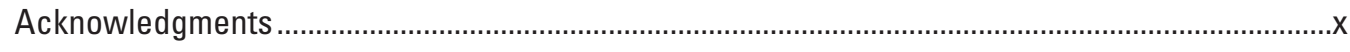

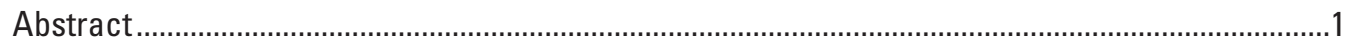

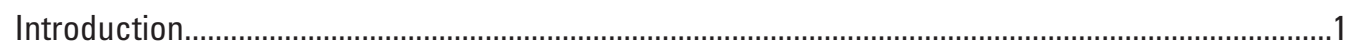

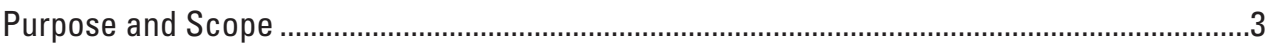

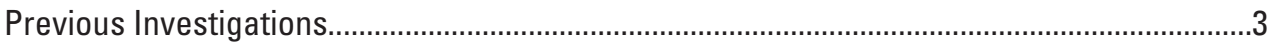

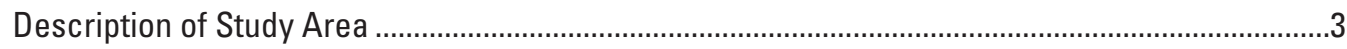

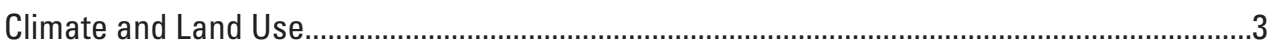

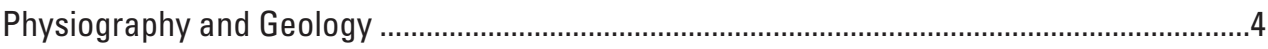

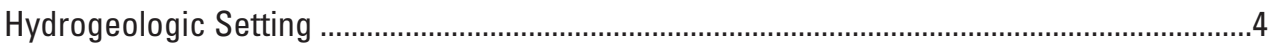

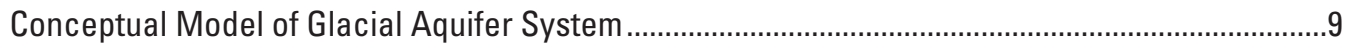

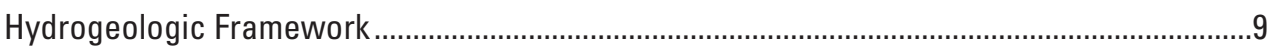

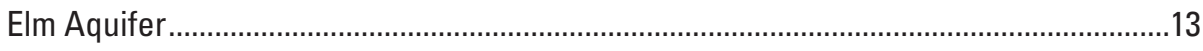

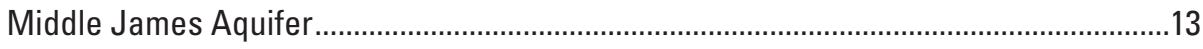

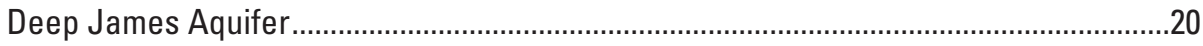

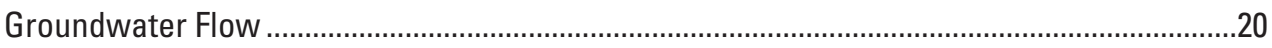

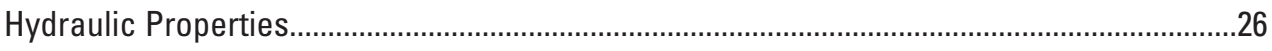

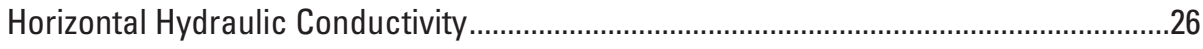

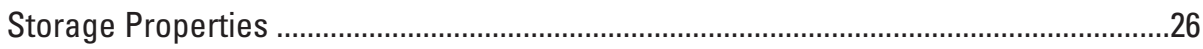

Vertical Hydraulic Conductivity .....................................................................................26

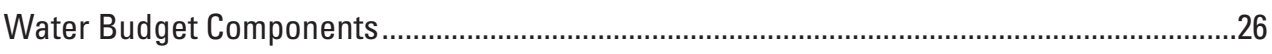

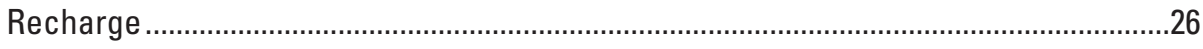

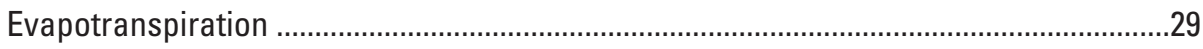

Interaction with Surface Water.....................................................................................32

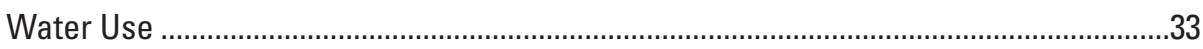

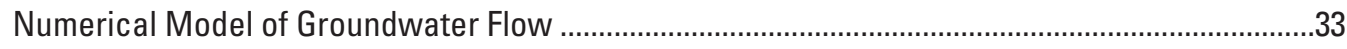

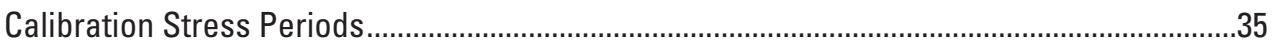

Finite-Difference Grid and Boundary Conditions ...................................................................35

Representation of Hydraulic Properties ...................................................................................36

Representation of Water Budget Components........................................................................46

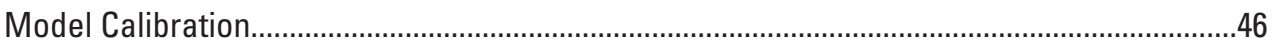

Calibrated Parameters .................................................................................................... 51

Simulated Water Budget Components ..................................................................................57

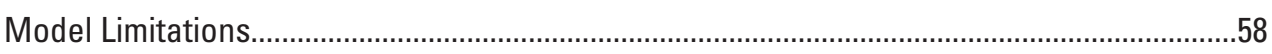

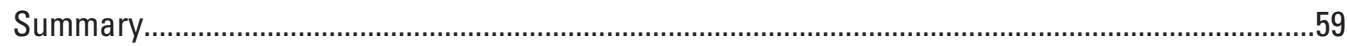

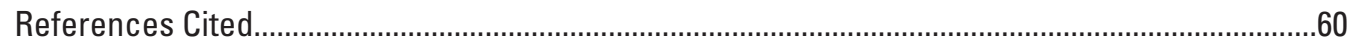

Supplement 1. Electromagnetic Geophysical Surveys.....................................................................64

Supplement 2. Direct-Current Electrical Resistivity Geophysical Surveys ......................................68

Supplement 3. Aquifer Test of Elm Aquifer at Eyestone Pit ...............................................................77

Supplement 4. Estimates of Hydraulic Conductivity from Specific Capacity Tests .........................80

Supplement 5. Estimating Vertical Hydraulic Conductivity of Sediments Separating the

Elm River and Elm Aquifer using Temperature ..................................................................81

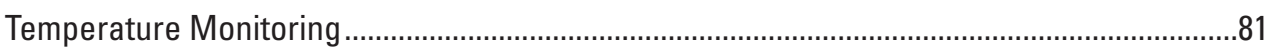

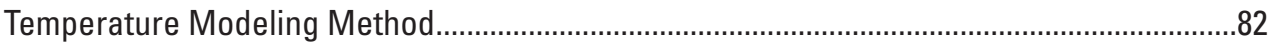

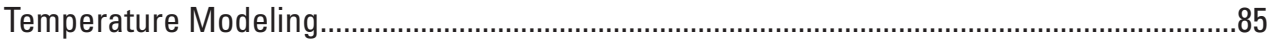


Supplement 6. Analysis of Recharge with a Soil-Water-Balance Method 92

Supplement 7. Water-Level Data for Generalized Potentiometric Surface of Elm Aquifer.. 96

\section{Figures}

1. Map showing location of study area and physiographic divisions in eastern South Dakota

2. Graph showing cumulative departure of precipitation from monthly averages for 1931-2009 at station 390020

3. Map showing major land-use categories in model area …...............................................

4. Map showing land-surface altitude in the model area ........................................................

5. Map showing geology, landforms, and approximate location of pre-glacial channels in the model area.

6. Map showing the extents of the Elm and Middle James aquifers in model area .............8

7. Map showing location of lithologic logs used in interpretation of hydrogeologic framework in study area and map of bedrock surface in model area..............................10

8. Map showing glacial aquifer boundaries in model area ...............................................11

9. Map showing thickness of glacial till overlying the Elm aquifer in model area...............12

10. Map showing thickness of the Elm aquifer in model area .............................................14

11. Map showing combined thickness of sand and gravel deposits within the

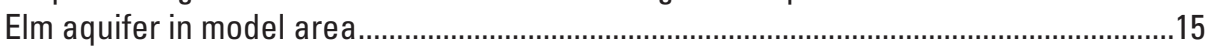

12. Map showing altitude of the top of the Elm aquifer in model area .................................16

13. Map showing thickness of the Middle James aquifer in model area .............................17

14. Map showing combined thickness of sand and gravel deposits within the Middle James aquifer ..................................................................................................

15. Map showing thickness of confining layer 1 in model area...........................................19

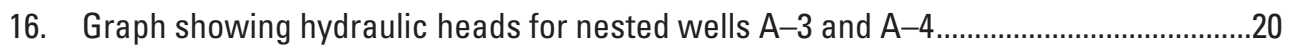

17. Map showing location of test holes in the Deep James aquifer and interpolated thickness in model area..................................................................................................21

18. Map showing generalized average potentiometric surface for the Elm aquifer in model area

19. Map showing distribution of confined and unconfined areas in the Elm aquifer in model area

20. Map showing simulated steady-state potentiometric surface of the Middle James aquifer

21. Map showing simulated steady-state potentiometric surface of the Deep James aquifer. .25

22. Map showing location of aquifer test sites and selected hydrologic features ..............27

23. Map showing location of temperature monitoring sites and piezometers in model area. Location of counties in which vertical hydraulic conductivity studies have been conducted.

24. Map showing spatial distribution of mean annual recharge to the Elm aquifer in water years 1975-2009, calculated with the soil-water-balance method, in model area.....

25. Map showing spatial distribution of average annual potential evapotranspiration in water years 1975-2009 in model area, calculated by using soil-water-balance derived potential evapotranspiration, which was modified with a till thickness multiplier array 
26. Graph showing comparison of precipitation, hydraulic head in Elm aquifer for wells $A-1$ and $A-2$, and stage in Elm River .....

27. Map showing location of production wells and South Dakota Department of Environment and Natural Resources observation wells in model area ...........................34

28. Map showing boundary conditions for model layer 1 ......................................................37

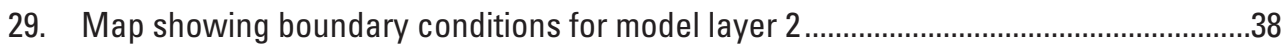

30. Map showing boundary conditions for model layer 3 ......................................................39

31. Graphs showing range in time-variant specified-head boundaries assigned for model layer 1 for all stress periods..................................................................................40

32. Graphs showing range in time-variant specified-head boundaries assigned for model layer 2 for all stress periods.

33. Graphs showing range in time-variant specified-head boundaries assigned for model layer 3 for all stress periods.

34. Map showing mean hydraulic head altitudes for wells completed in the Middle James aquifer.....

35. Map showing mean of hydraulic head altitudes for wells completed in the Deep James aquifer

36. Map showing horizontal hydraulic conductivity zones for model layer 1 and location of pilot points.

37. Map showing distribution of recharge parameters in model area as defined by glacial till thickness.

38. Map showing location of vertical conductance sites, river cell parameter groups for Elm River and Foot Creek, and drain cell parameter group for Moccasin Creek..

39. Map showing location of wells with water-level data used for model calibration and number of water-level measurements per well.

40. Graph showing linear regression between simulated and observed hydraulic heads for all aquifers .

41. Map showing simulated potentiometric surface for average conditions for water years 1975-2009 and mean difference between simulated and observed transient hydraulic heads for model layer 1

42. Graphs showing simulated and observed hydraulic heads for model layer 1 for long-term observation wells

43. Map showing simulated potentiometric surface of average conditions for water years 1975-2009 and mean difference between simulated and observed transient hydraulic heads for model layer 2 .

44. Map showing simulated potentiometric surface of average conditions for water years 1975-2009 and mean difference between simulated and observed transient hydraulic heads for model layer 3

45. Map showing calibrated horizontal hydraulic conductivity distribution for model layer 1

46. Graph showing simulated recharge and evapotranspiration rates by water year .........58

47. Graph showing simulated gain or loss of groundwater in the Elm aquifer along the Elm River 


\section{Supplement Figures}

S1-1. Map showing location of electromagnetic survey lines and wells

S1-2. Graph showing relation between percentage of sand and gravel deposits and apparent electrical resistivity at a frequency of 13,590 hertz

S1-3. Map showing apparent electrical resistivity distribution at a frequency of 13,590 hertz

S2-1. Map showing location of direct-current electrical resistivity surveys and glacial landforms.

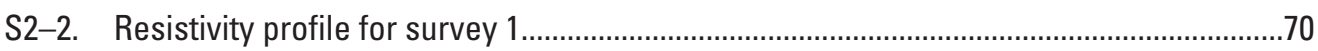

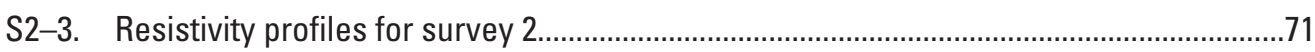

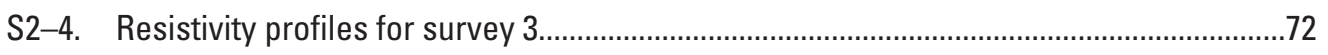

S2-5. Resistivity profile for survey 4.................................................................................

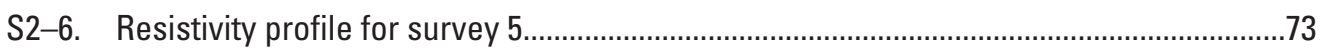

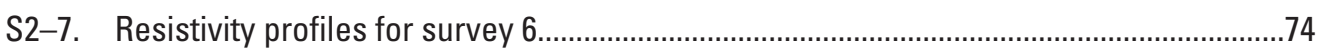

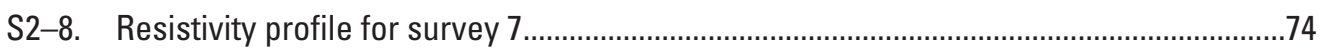

S2-9. Resistivity profile for survey 8

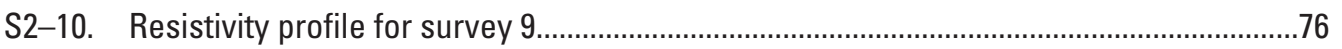

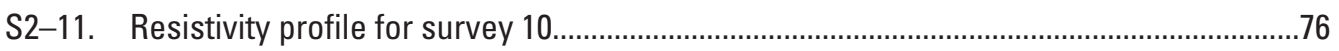

S3-1. Map showing location of Eyestone Pit, pumping well, and observation wells for

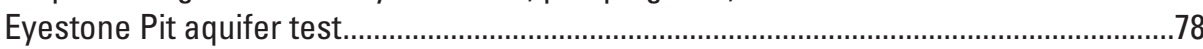

S3-2. Graph comparing hydraulic head for observation wells Pit1, PZ2, PZ3, and PZ5, and trends in hydraulic head ........................................................................................

S5-1. Photograph showing stainless steel casing and temperature logger.............................81

S5-2. Cross-section representation of relative temperature variation in gaining and losing stream reaches ..................................................................................................82

S5-3. Graph showing observed and simulated temperature for site T1 ..................................86

S5-4. Graph showing observed and simulated temperature for site T2, 2008 .........................86

S5-5. Graph showing observed and simulated temperature for site T2, 2009........................87

S5-6. Graph showing observed and simulated temperature for site T3 ..................................87

S5-7. Graph showing observed and simulated temperature for site T4 ..................................88

S5-8. Graph showing observed and simulated temperature for site T5 ...................................88

S5-9. Graph showing observed and simulated temperature for site T6 .................................89

S5-10. Graph showing observed and simulated temperature for site T7 ..................................89

S5-11. Graph showing observed and simulated temperature for site T8 .................................90

S5-12. Graph showing observed and simulated temperature for site T9 ...................................90

S5-13. Graph showing observed and simulated temperature for site T10 .................................91

S5-14. Graph showing observed and simulated temperature for site T11 .................................91

S6-1. Map showing soil type as defined for recharge calculations in soil-water-balance method. 


\section{Tables}

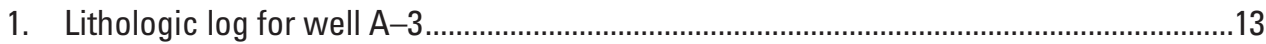

2. Vertical hydraulic conductivity of sediments separating the Elm River and

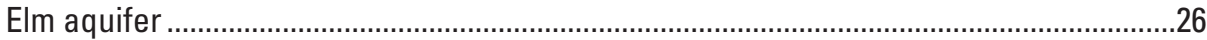

3. Vertical hydraulic conductivity of glacial till in eastern South Dakota.............................29

4. Comparison of selected streamflow measurements at U.S. Geological Survey streamgage 06471510 with mean daily streamflow at U.S. Geological Survey

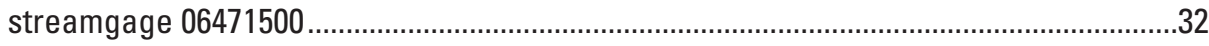

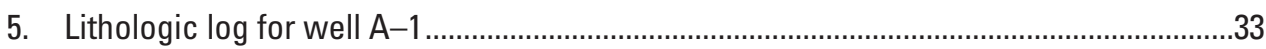

6. Lithologic log for well A-2 .............................................................................................33

7. Summary of seasonal mean daily streamflow at U.S. Geological Survey

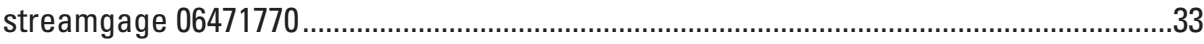

8. Estimated water-use rates, for water years 1975-2009 .................................................35

9. Simulated stress periods, water years 1975-2009 ......................................................36

10. Hydraulic conductivity parameter zones representing model layer 1 .............................46

11. Vertical conductance at selected sites near Elm River .................................................49

12. Streamflow measurements in the fall at Moccasin Creek at Aberdeen, South Dakota .............................................................................................................

13. Calibrated values for model parameters …………....................................................51

14. Simulated water budgets for water years 1975-2009, water year 1976, and water

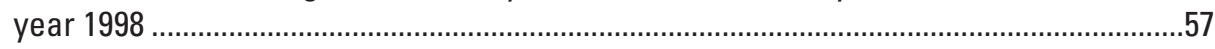

15. Recharge parameter boundaries and calibrated multiplier values ................................58

\section{Supplement Tables}

S1-1. Approximate values and typical ranges of selected properties of some common geologic materials ....................................................................................................64

S1-2. Station names and depths of lithologic logs that were compared with electromagnetic resistivity surveys................................................................................66

S2-1. Station names and depths of lithologic logs that were compared with direct-current electrical resistivity surveys .......................................................................68

S3-1. Pumping rate and time for each stress period ................................................................77

S3-2. Observed and simulated drawdown for the Eyestone Pit aquifer test..............................79

S4-1. Specific capacity data and estimated hydraulic conductivity for seven

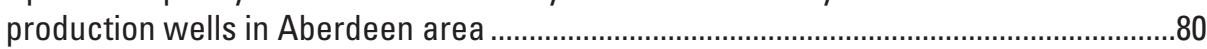

S5-1. Piezometers completed in the Elm aquifer near the Elm River .......................................83

S5-2. Darcy velocity, hydraulic gradient, and vertical hydraulic conductivity at temperature monitoring sites .

S5-3. Thermal and physical properties used in the finite-difference approximation of

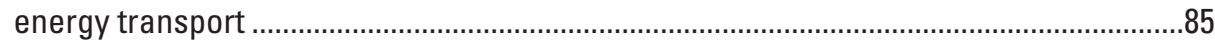

S6-1. Infiltration rates assigned by soil type and till thickness..............................................92

S6-2. Interception storage values and depth of root zone assigned by land-cover

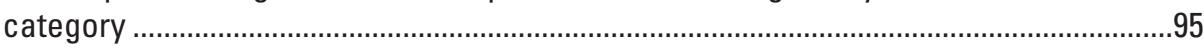

S7-1. Water-level data for generalized average potentiometric surface of Elm Aquifer ..........96 


\section{Conversion Factors}

Inch/Pound to SI

\begin{tabular}{|c|c|c|}
\hline Multiply & By & To obtain \\
\hline \multicolumn{3}{|c|}{ Length } \\
\hline inch (in.) & 2.54 & centimeter $(\mathrm{cm})$ \\
\hline foot $(\mathrm{ft})$ & 0.3048 & meter $(\mathrm{m})$ \\
\hline mile (mi) & 1.609 & kilometer $(\mathrm{km})$ \\
\hline \multicolumn{3}{|c|}{ Area } \\
\hline square mile $\left(\mathrm{mi}^{2}\right)$ & 259.0 & hectare (ha) \\
\hline square mile $\left(\mathrm{mi}^{2}\right)$ & 2.590 & square kilometer $\left(\mathrm{km}^{2}\right)$ \\
\hline square feet $\left(\mathrm{ft}^{2}\right)$ & 0.09290 & square meter $\left(\mathrm{m}^{2}\right)$ \\
\hline \multicolumn{3}{|c|}{ Volume } \\
\hline gallon (gal) & 3.785 & liter (L) \\
\hline gallon (gal) & 0.003785 & cubic meter $\left(\mathrm{m}^{3}\right)$ \\
\hline cubic foot $\left(\mathrm{ft}^{3}\right)$ & 0.02832 & cubic meter $\left(\mathrm{m}^{3}\right)$ \\
\hline \multicolumn{3}{|c|}{ Flow rate } \\
\hline cubic foot per second $\left(\mathrm{ft}^{3} / \mathrm{s}\right)$ & 0.02832 & cubic meter per second $\left(\mathrm{m}^{3} / \mathrm{s}\right)$ \\
\hline gallon per minute (gal/min) & 0.06309 & liter per second $(\mathrm{L} / \mathrm{s})$ \\
\hline inch per year (in/yr) & 25.4 & millimeter per year (mm/yr) \\
\hline foot per second (ft/s) & 0.3048 & meter per second $(\mathrm{m} / \mathrm{s})$ \\
\hline \multicolumn{3}{|c|}{ Hydraulic conductivity } \\
\hline foot per day (ft/d) & 0.3048 & meter per day $(\mathrm{m} / \mathrm{d})$ \\
\hline \multicolumn{3}{|c|}{ Transmissivity* } \\
\hline foot squared per day $\left(\mathrm{ft}^{2} / \mathrm{d}\right)$ & 0.09290 & meter squared per day $\left(\mathrm{m}^{2} / \mathrm{d}\right)$ \\
\hline \multicolumn{3}{|c|}{ Conductance } \\
\hline feet squared per day $\left(\mathrm{ft}^{2} / \mathrm{d}\right)$ & 0.0929 & meter squared per day $\left(\mathrm{m}^{2} / \mathrm{d}\right)$ \\
\hline
\end{tabular}

Temperature in degrees Fahrenheit $\left({ }^{\circ} \mathrm{F}\right)$ may be converted to degrees Celsius $\left({ }^{\circ} \mathrm{C}\right)$ as follows: ${ }^{\circ} \mathrm{C}=\left({ }^{\circ} \mathrm{F}-32\right) / 1.8$

Vertical coordinate information is referenced to the North American Vertical Datum of 1988 (NAVD 88).

Horizontal coordinate information is referenced to the North American Datum of 1983 (NAD 83).

Altitude, as used in this report, refers to distance above the vertical datum.

*Transmissivity: The standard unit for transmissivity is cubic foot per day per square foot times foot of aquifer thickness [(ft $\left./ \mathrm{d}) / \mathrm{ft}^{2}\right] \mathrm{ft}$. In this report, the mathematically reduced form, foot squared per day $\left(\mathrm{ft}^{2} / \mathrm{d}\right)$, is used for convenience.

Water year (WY) is the 12-month period, 0ctober 1 through September 30 , and is designated by the calendar year in which it ends. 


\section{Abbreviations and Acronyms}

$\begin{array}{ll}\text { EM } & \text { electromagnetic } \\ \text { GIS } & \text { geographic information system } \\ \mathrm{Hz} & \text { hertz } \\ \mathrm{H} / \mathrm{m} & \text { Henrys per meter } \\ \mathrm{kHz} & \text { kilohertz } \\ \mathrm{mS} / \mathrm{m} & \text { millisiemens per meter } \\ \text { NAVD88 } & \text { North American Vertical Datum of 1988 } \\ \text { NOAA } & \text { National Oceanic and Atmospheric Administration } \\ \text { ohm-m } & \text { ohm-meters } \\ \text { PEST } & \text { Parameter ESTimation code } \\ \text { R } & \text { coefficient of determination } \\ \text { SDDENR } & \text { South Dakota Department of Environment and Natural Resources } \\ \text { SDDENR-WR } & \text { South Dakota Department of Environment and Natural Resources Water Rights } \\ \text { SDGS } & \text { Program } \\ \text { S/m } & \text { South Dakota Geological Survey } \\ \text { SWB } & \text { siemens per meter } \\ \text { USGS } & \text { soil-water balance } \\ \text { WY } & \text { U.S. Geological Survey } \\ & \text { water year }\end{array}$




\section{Acknowledgments}

The authors thank the city of Aberdeen for support of numerous studies that provided valuable information for this work. The South Dakota Department of Environment and Natural Resources (SDDENR) Geological Survey (SDGS) drilled test holes and constructed observation wells for this study. The SDGS lithologic database was the primary source of data for interpretation of the hydrogeologic framework. The city of Aberdeen and the Water Rights Program of the South Dakota Department of Natural Resources (SDDENR-WR) provided permitting and water-use data. The SDDENR-WR provided long-term water-level data from their groundwater monitoring network in the study area. 


\title{
Conceptual and Numerical Models of the Glacial Aquifer System North of Aberdeen, South Dakota
}

\author{
By Katrina A. Marini', Galen K. Hoogestraat ${ }^{2}$, Katherine R. Aurand ${ }^{2}$, and Larry D. Putnam²
}

\section{Abstract}

This U.S. Geological Survey report documents a conceptual and numerical model of the glacial aquifer system north of Aberdeen, South Dakota, that can be used to evaluate and manage the city of Aberdeen's water resources. The glacial aquifer system in the model area includes the Elm, Middle James, and Deep James aquifers, with intervening confining units composed of glacial till.

The Elm aquifer ranged in thickness from less than 1 to about 95 feet (ft), with an average thickness of about $24 \mathrm{ft}$; the Middle James aquifer ranged in thickness from less than 1 to $91 \mathrm{ft}$, with an average thickness of $13 \mathrm{ft}$; and the Deep James aquifer ranged in thickness from less than 1 to $165 \mathrm{ft}$, with an average thickness of $23 \mathrm{ft}$. The confining units between the aquifers consisted of glacial till and ranged in thickness from 0 to $280 \mathrm{ft}$. The general direction of groundwater flow in the Elm aquifer in the model area was from northwest to southeast following the topography. Groundwater flow in the Middle James aquifer was to the southeast. Sparse data indicated a fairly flat potentiometric surface for the Deep James aquifer. Horizontal hydraulic conductivity for the Elm aquifer determined from aquifer tests ranged from 97 to 418 feet per day $(\mathrm{ft} / \mathrm{d})$, and a confined storage coefficient was determined to be $2.4 \times 10^{-5}$. Estimates of the vertical hydraulic conductivity of the sediments separating the Elm River from the Elm aquifer, determined from the analysis of temperature gradients, ranged from 0.14 to $2.48 \mathrm{ft} / \mathrm{d}$.

Average annual precipitation in the model area was 19.6 inches per year (in/yr), and agriculture was the primary land use. Recharge to the Elm aquifer was by infiltration of precipitation through overlying outwash, lake sediments, and glacial till. The annual recharge for the model area, calculated by using a soil-water-balance method for water year (WY) 1975-2009, ranged from 0.028 inch in WY 1980 to 4.52 inches in WY 1986, with a mean of 1.56 inches. The annual potential evapotranspiration, calculated in soil-waterbalance analysis, ranged from 21.8 inches in WY 1983 to 27.0 inches in WY 1985, with a mean of 24.6 inches. Water use from the glacial aquifer system primarily was from the

\footnotetext{
${ }^{1}$ South Dakota School of Mines and Technology.

${ }^{2}$ U.S. Geological Survey.
}

Elm aquifer for irrigation, municipal, and suburban water supplies, and the annual rate ranged from 1.0 to 2.4 cubic feet per second $\left(\mathrm{ft}^{3} / \mathrm{s}\right)$.

The MODFLOW-2005 numerical model represented the Elm aquifer, the Middle James aquifer, and the Deep James aquifer with model layers 1-3 respectively separated by confining layers 1-2 respectively. Groundwater flow was simulated with 75 stress periods beginning October 1, 1974, and ending September 30, 2009. Model grid spacing was 200 by $200 \mathrm{ft}$ and boundaries were represented by specified-head boundaries and no-flow boundaries. The model used parameter estimation that focused on minimizing the difference between 954 observed and simulated hydraulic heads for 135 wells. Calibrated mean horizontal hydraulic conductivity values for model layers 1-3 were 94, 41, and $30 \mathrm{ft} / \mathrm{d}$ respectively. Vertical hydraulic conductivity values for confining layers 1 and 2 were 0.0002 and $0.0003 \mathrm{ft} / \mathrm{d}$, respectively. Calibrated specific yield for model layer 1was 0.1 and specific storage ranged from 0.0003 to 0.0005 per foot. Calibrated mean recharge rates ranged from $2.5 \mathrm{in} / \mathrm{yr}$ where glacial till thickness was less than $10 \mathrm{ft}$ to $0.8 \mathrm{in} / \mathrm{yr}$ where glacial till thickness was greater than $30 \mathrm{ft}$. Calibrated mean annual evapotranspiration rate was $8.8 \mathrm{in} / \mathrm{yr}$. Simulated net streamflow gain from model layer 1 was $3.1 \mathrm{ft}^{3} / \mathrm{s}$.

\section{Introduction}

The city of Aberdeen in northeastern South Dakota (fig. 1) is developing plans and strategies for a sustainable water supply. Drought conditions during 2000-2004 and the prospect of economic expansion have heightened the need to identify additional water-supply alternatives.

The current (2012) primary source of water for the city is the Elm River (Janel Ellingson, City of Aberdeen, oral commun., 2012). Water is drawn into the water treatment plant from the river by an intake located about 6 miles (mi) northeast of the city. During low-flow conditions, Willow Creek and Elm Lake reservoirs are available to release water from storage about 15 and $25 \mathrm{mi}$ upstream, respectively. The natural channel of Elm River is used to deliver water to the intake at the water treatment plant. Streamflow records for the 

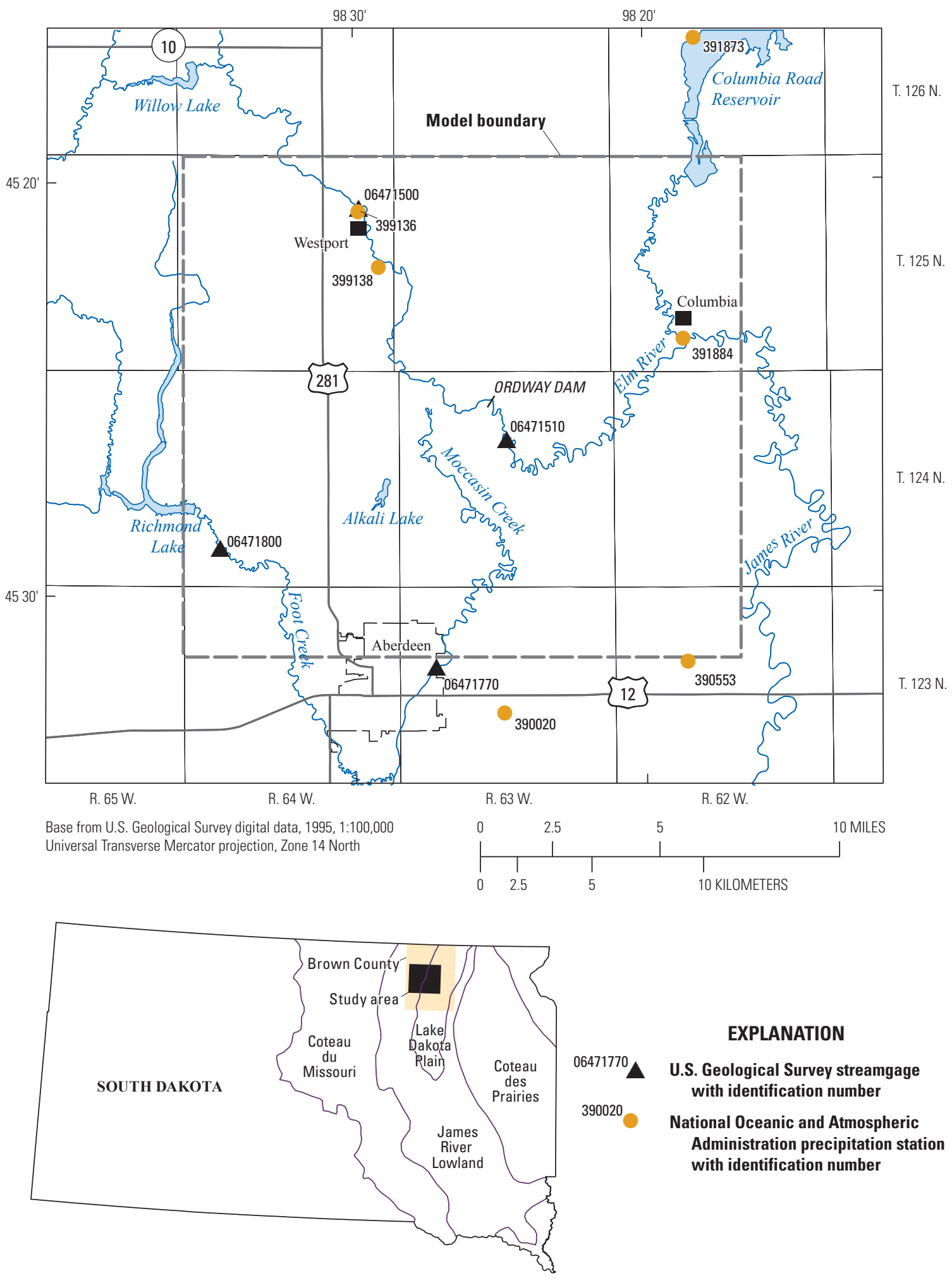

Figure 1. Location of study area and physiographic divisions in eastern South Dakota (from Flint, 1955). 
U.S. Geological Survey (USGS) streamgage on the Elm River at Westport (streamgage 06471500) for the period 1946-2009 indicate that flow in Elm River is less than 5.4 cubic feet per second $\left(\mathrm{ft}^{3} / \mathrm{s}\right)$ about 50 percent of the time (U.S. Geological Survey, 2011). Groundwater is used as a supplemental water source in the Aberdeen area. Groundwater is pumped from the Elm aquifer, a shallow glacial aquifer, from wells located about 7 mi north of Aberdeen. Several new production wells have been added in recent years with the future plan of utilizing groundwater and surface-water sources (Janel Ellingson, City of Aberdeen, oral commun., 2012).

Periodic drought and potential future increases in water use have raised concerns about declining flows in the Elm River and water-level declines in the small storage reservoirs, as well as in the Elm aquifer. To help address these concerns, the USGS, in cooperation with the city of Aberdeen, developed conceptual and numerical models of the glacial aquifer system north of Aberdeen to provide a scientific foundation for evaluating and managing the water resources near Aberdeen.

\section{Purpose and Scope}

The purposes of this report are to describe hydrologic field investigations to characterize the properties of the glacial aquifer system north of Aberdeen and to document conceptual and numerical models of groundwater flow in the glacial aquifer system. The construction and calibration of a numerical model of the glacial aquifer system is described.

\section{Previous Investigations}

Rothrock (1955) investigated possible sources of water for the city of Aberdeen in response to the drought of 1934, during which all forms of surface water were reduced to unusable flows. The geology and water resources of Brown County (where the city of Aberdeen is located) were documented by Koch and Bradford (1976). This investigation defined the spatial extent of three glacial aquifers - the Elm, Middle James, and Deep James aquifers — within the study area. Tipton (1977) completed a study of the groundwater system near Aberdeen to determine whether the Elm or Middle James aquifers could provide the city with sufficient water to increase or replace the water sources being used at that time. Leap (1986) described the geology of Brown County, from the surficial glacial deposits to the Precambrian igneous and metamorphic rocks, and produced a detailed map of the glacial landforms within the county. Emmons (1987) investigated the potential well yields of the Elm and Middle James aquifers as well as the potential for artificial recharge to the aquifers in the James River Basin as part of a study in cooperation with the Bureau of Reclamation. Emmons (1990) used a numerical model to characterize the glacial aquifer system in the northern three-fourths of Brown County. Three glacial aquifer layers (Elm, Middle James, and Deep James) were simulated, each separated by a confining layer. The maximum steady-state recharge rate was determined to be approximately 7.0 inches per year (in/yr), and the maximum potential evapotranspiration rate was $35.4 \mathrm{in} / \mathrm{yr}$. Recharge rates were calculated as a function of till depth overlying the Elm aquifer. Recharge from precipitation accounted for about 95 percent of the water entering the glacial aquifer system, and evapotranspiration accounted for about 95 percent of water leaving the system (Emmons, 1990). Schaap (2000) reported hydraulic properties of the Elm aquifer estimated by using a local aquifer test, resulting in a transmissivity of about 24,000 feet squared per day $\left(\mathrm{ft}^{2} / \mathrm{d}\right)$, hydraulic conductivity of about 600 feet per day $(\mathrm{ft} / \mathrm{d})$, and specific yield of about 0.42 .

\section{Description of Study Area}

The 490-square mile (mi²) study area (fig. 1), located in the west-central part of Brown County north of Aberdeen, includes a buffer about $3.5 \mathrm{mi}$ wide around the perimeter of the glacial aquifer system analyzed with the numerical model (model area). The purpose of this buffer area was to include selected precipitation stations and observation wells used in conceptual model development for the model area. The model area was centered on the part of the glacial aquifer system identified as most likely to be considered for future groundwater development by the city of Aberdeen. The boundaries of the model area were selected to take advantage of as many natural hydrologic boundaries for the numerical model as possible, and to be distant enough from the potential groundwater development area to minimize the effects of boundary conditions on simulations of hypothetical stress on the aquifer system.

\section{Climate and Land Use}

The climate in the study area is continental with cold winters and hot summers. Long-term precipitation and temperature records were available for two National Oceanic and Atmospheric Administration (NOAA) precipitation stations, 390020 and 391873 (fig. 1). Five additional stations in the study had records for shorter time periods. Cumulative departure from the long-term (1931-2009) average for monthly precipitation at station 390020 (fig. 2) shows periods of below average precipitation from 1958-1976 and above average precipitation from 1993-2001. Average annual precipitation for the 1931-2009 period was $19.6 \mathrm{in} / \mathrm{yr}$ (National Climate Data Center, 2011). The 1958-1976 period averaged $2.5 \mathrm{in} / \mathrm{yr}$ less than the long-term average, and the 1993-2001 period averaged $4.8 \mathrm{in} / \mathrm{yr}$ greater than the long-term average.

Normal average temperatures (1971-2000) for January were 8.2 degrees Fahrenheit $\left({ }^{\circ} \mathrm{F}\right)$ at station 391873 and $11.0^{\circ} \mathrm{F}$ at station 390020 . The normal average temperatures for July were $71.2^{\circ} \mathrm{F}$ at station 391973 and $72.2^{\circ} \mathrm{F}$ at station 390020 (National Climate Data Center, 2011). 


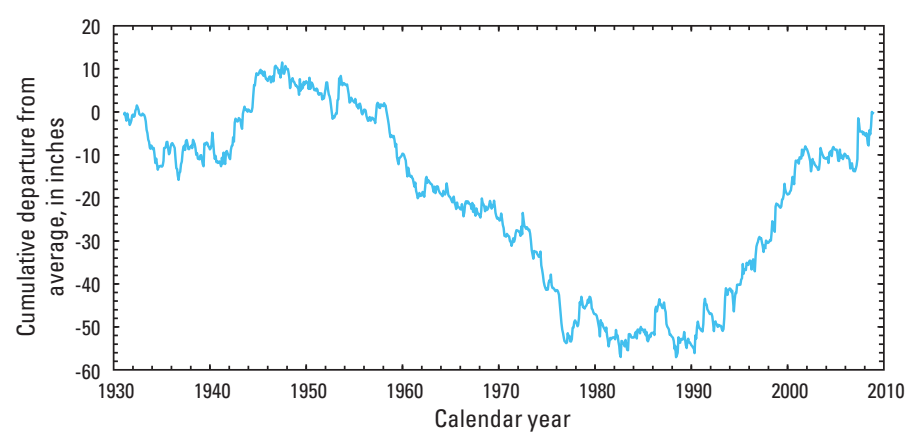

Figure 2. Cumulative departure of precipitation from monthly averages for 1931-2009 at station 390020. (Data from National Climate Data Center, 2011.)

The major land use in the model area is for agriculture (fig. 3). About 86 percent of the land in the model area is used for cultivated crops, pasture, and hay (Multi-Resolution Land Characteristics Consortium, 2011). Developed areas represent about 6 percent, wetlands about 5 percent, and other categories about 3 percent of the land in the model area.

\section{Physiography and Geology}

The study area is located within the James River Lowland physiographic division (fig. 1), which is a lowland about $200 \mathrm{mi}$ long and $50 \mathrm{mi}$ wide drained by the James River with local relief rarely exceeding 20 to 30 feet (ft) (Flint, 1955). The James River Lowland is located between two coteaus at higher altitude, the Coteau du Missouri and the Coteau des Prairies (fig. 1). The eastern part of the study area includes the Lake Dakota Plain, which is the floor of an abandoned glacial lake in the James River Lowland that is about $90 \mathrm{mi}$ long in South Dakota. The Lake Dakota Plain, which is the result of deposition of fine-grained lake deposits, is flat with local relief in many places no more than $10 \mathrm{ft}$ (Flint, 1955). Glaciation in Brown County resulted entirely from the southward advance of the James Lobe, of late Wisconsin age of the Pleistocene Epoch, through the James River Basin (Leap, 1986). As the glacial ice receded up the James River Basin, a broad complex of recessional moraines, which impounded meltwater from the ice sheet, formed ancient Lake Dakota (Leap, 1986). The part of the study area to the west of the Lake Dakota Plain consists of highlands within the James River Lowland that are mostly recessional and ground moraines.

The general extent of the Lake Dakota Plain and the highlands is evident on a map of the land-surface altitude (U.S. Geological Survey, 2006) in the model area (fig. 4). The land-surface altitude in the Lake Dakota Plain is less than 1,310 ft above the North American Vertical Datum of 1988 (NAVD 88). The land-surface altitude in the highlands area increases from about 1,310 ft adjacent to the Lake Dakota Plain to greater than $1,400 \mathrm{ft}$ in the northwest corner of the study area. The orientation of the relief in the highlands reflects the northeast to southwest orientation of the glacial moraine.
A map of the geology and landforms modified from Leap (1986) shows characteristic elements of the glacial aquifer system (fig. 5). Recessional moraine landforms are more hummocky and rugged than those of ground moraine (Leap, 1986). Ground moraine represents a period when the glacier retreated at a rapid and steady rate, leaving a smoother surface than recessional moraine. The recessional moraine was deposited when the ice sheet was at equilibrium, resulting in meltwater moving along the margins of the ice sheet forming ridges. As the glacier retreated, meltwater channels formed along what are now the Elm River and Foot Creek. The meltwater channels flowed toward ancient Lake Dakota creating deltas where the larger grained sediments were deposited along the channel or near the mouth and finer grained sediments were carried farther out into Lake Dakota. The meltwater channels (fig. 5) were larger than the current channel, in which flows are much smaller. The approximate widths of the meltwater channels are evident from the low land-surface altitude along present-day streams (fig. 4). After the ice had retreated from the James River Basin, Lake Dakota was still receiving water from melting stagnant ice on the Coteau du Missouri and Coteau des Prairies (fig. 1), located on the edges of James River Lowland (Leap, 1986). Eventually the morainal dam was breached, and Lake Dakota drained southward. As the melting ice diminished, flow in the meltwater channel decreased and new smaller channels were formed. New paths were established across the Lake Dakota Plain to connect to the James River, which was incising into the lacustrine sediments.

Before the Pleistocene Epoch, the Grand-Moreau-Cheyenne channel served as northward drainage in Brown County (Leap, 1986). The channel (fig. 5) in the bedrock surface was at an altitude of about 1,000 ft in the model area, with the highlands on the western side of the model area rising to about 1,400 ft and on the eastern side to about 1,200 ft. Minor channels might have been tributaries to the main channel; all of the channels were modified by the action of the ice and meltwater.

Glacial outwash consisting of sorted gravel, sand, and silt constitutes the most permeable deposits in the model area. Outwash deposited in depressions in the glacial ice has limited areal extent and can vary in thickness from a few inches to $10 \mathrm{ft}$ (Leap, 1986). Outwash from buried meltwater channels has a larger areal extent and forms a complex network of cut and fill sequences that may or may not be hydraulically connected. Lower permeability silt, fine sand, and clay deposited in ancient Lake Dakota had a combined average thickness of about $75 \mathrm{ft}$ in Brown County (Koch and Bradford, 1976).

\section{Hydrogeologic Setting}

Koch and Bradford (1976) defined the spatial extent of three glacial aquifers - the Elm, Middle James, and Deep James aquifers - that ranged in depth from 15-100, 40-250, 


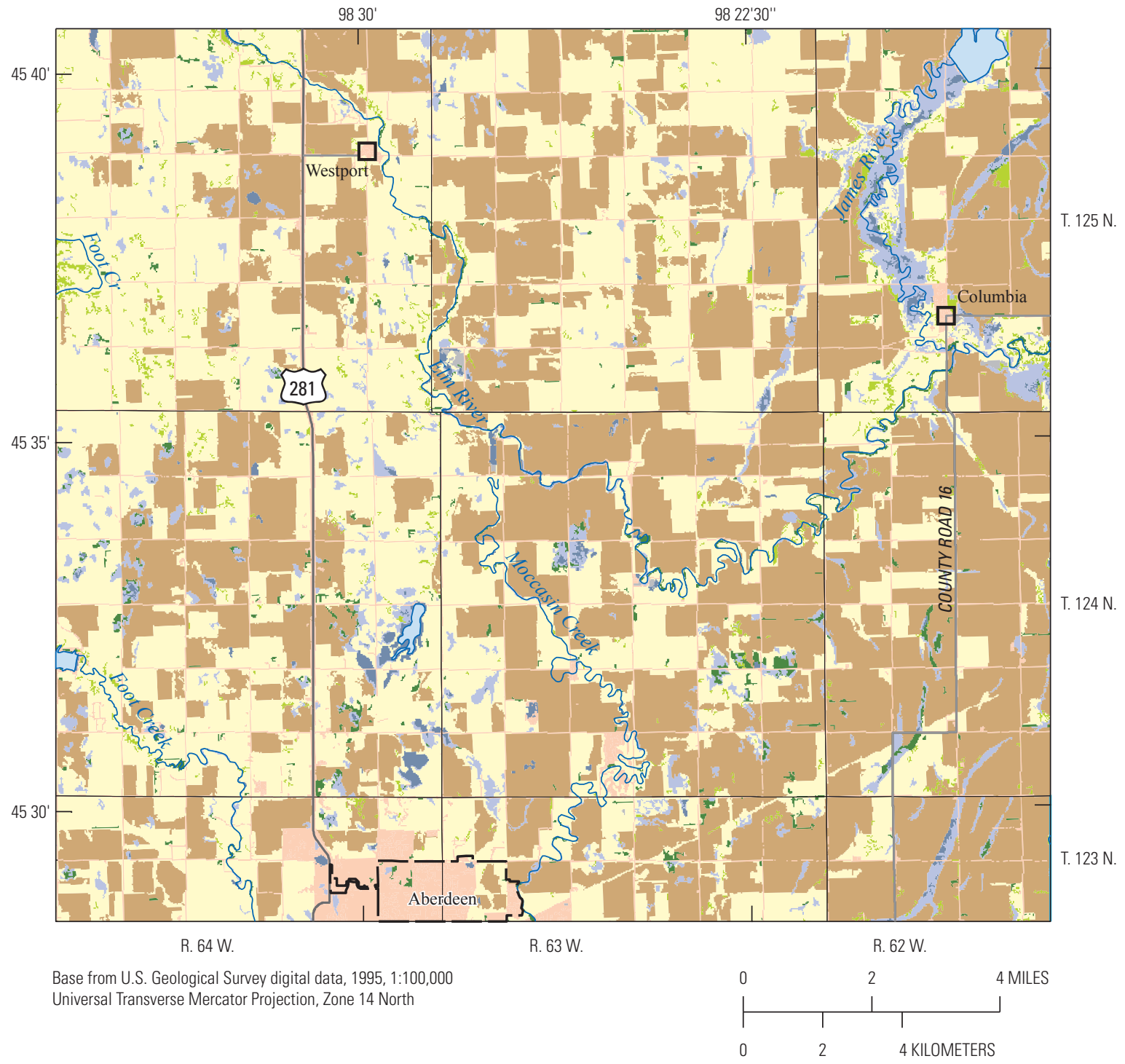

EXPLANATION

Land-use category (Multi-Resolution Land

Characteristics Consortium, 2011)

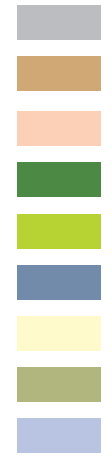

Barren land

Cultivated crops

Developed areas, various categories

Forest

Herbaceous grassland

Open water

Pasture or hay

Shrub / scrub

Woody or emergent herbaceous wetlands

Figure 3. Major land-use categories in model area. 


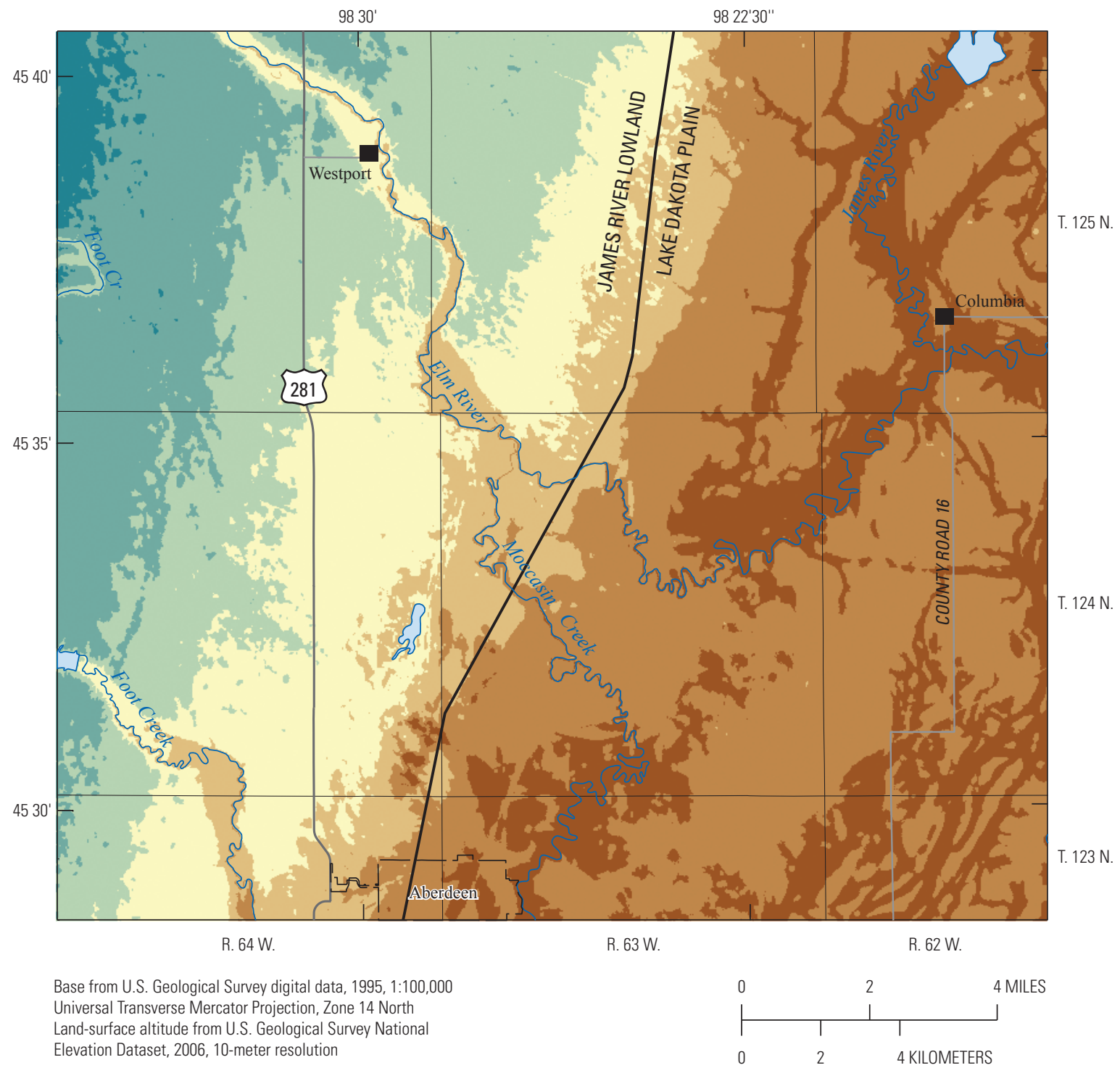

\section{EXPLANATION}

Land-surface altitude, in feet above North American Vertical Datum of 1988

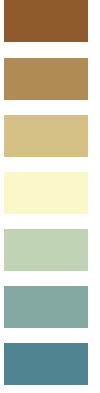

1,273 to less than 1,300

1,300 to less than 1,310

1,310 to less than 1,325

1,325 to less than 1,350

1,350 to less than 1,375

1,375 to less than 1,400

1,400 to less than 1,417

Boundary between physiographic divisions (from Flint, 1955)

Figure 4. Land-surface altitude in the model area. 


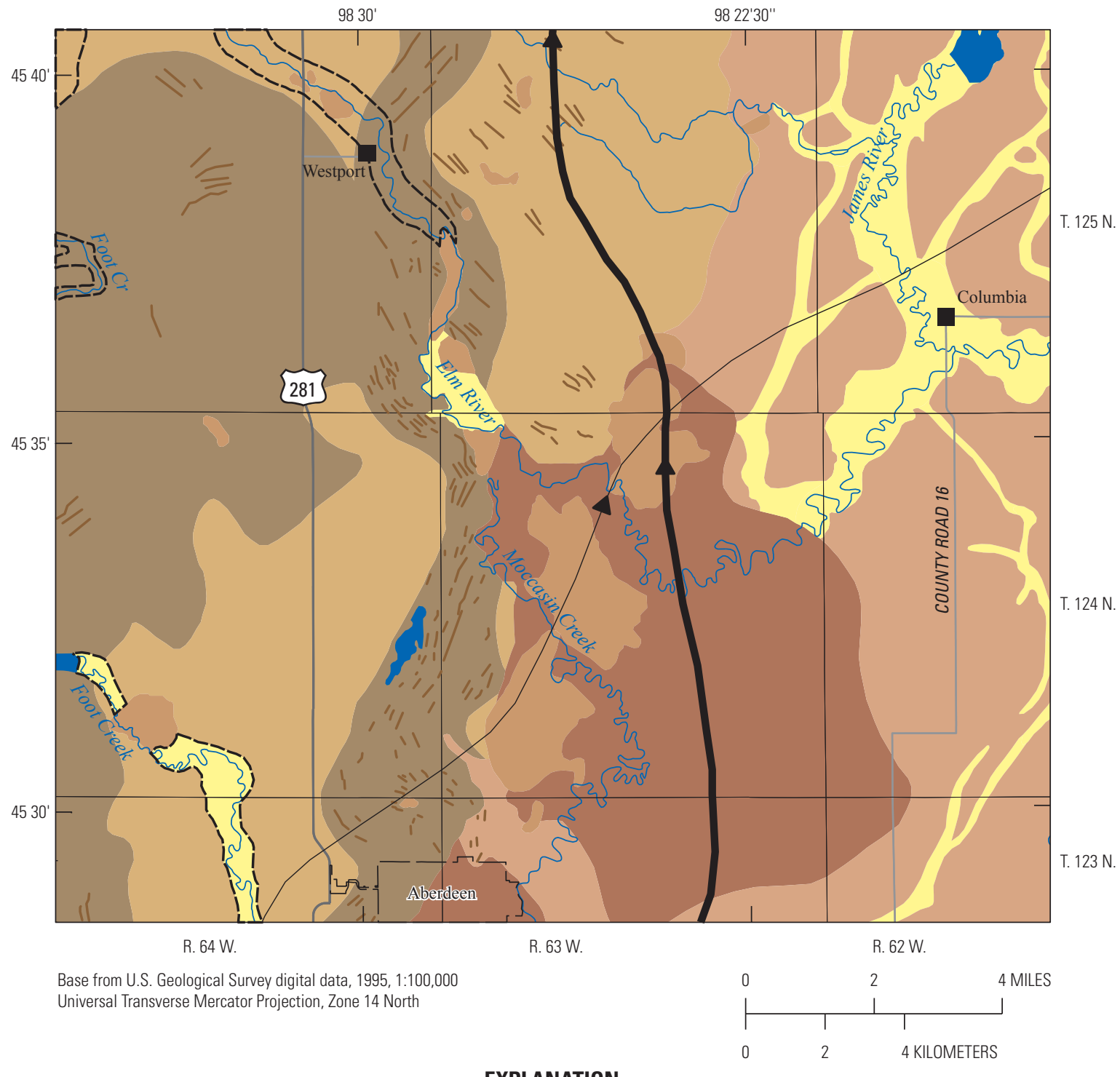

EXPLANATION

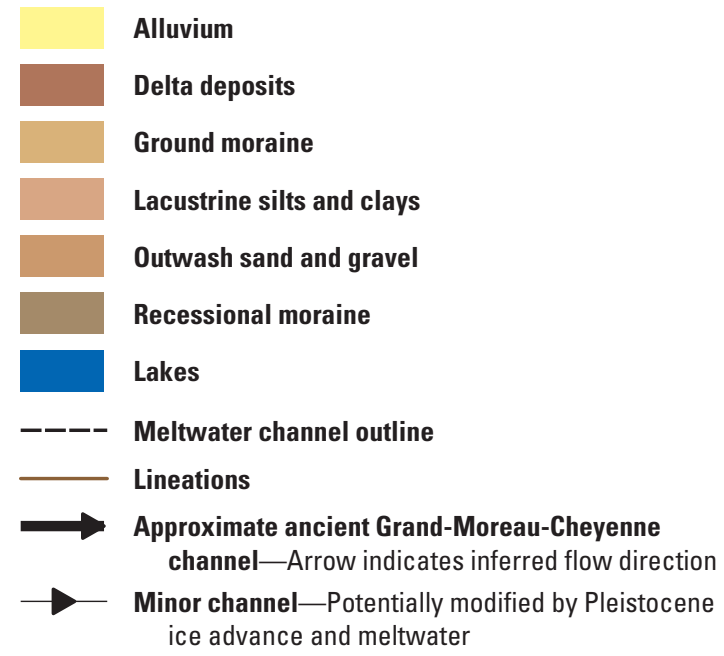

Figure 5. Geology, landforms, and approximate location of pre-glacial channels in the model area (modified from Leap, 1986). 
and 125-390 ft below land surface, respectively. Glacial aquifers in the model area consist primarily of outwash deposits composed of sorted gravel, sand, and silt. The outwash deposits were grouped as three aquifers by Koch and Bradford (1976) based on their altitude. The Elm aquifer exists between altitudes of about 1,225 and 1,400 ft, and is hydraulically connected to the lacustrine deposits underlying the Lake Dakota Plain (Koch and Bradford, 1976; Emmons, 1990). The areal extents of the Middle James and Elm aquifers as interpreted by Koch and Bradford (1976) are shown in figure 6 . The Middle James aquifer exists between altitudes of about 1,150 and 1,250 ft in the bedrock lowland and is lenticular with many clay layers. The Deep James aquifer (not shown in fig. 6) exists between altitudes of about 950 and 1,175 ft in the system of ancient river channels. Prior to glaciation in the model area, the Ancient GrandMoreau-Cheyenne Channel in Brown County drained north to the Arctic Ocean (Leap, 1986).

Recharge to the Elm aquifer is by infiltration of precipitation through overlying outwash, lake sediments, and till (Koch and Bradford, 1976). Recharge is substantially less in areas with greater thickness of overlying till (Emmons, 1990).

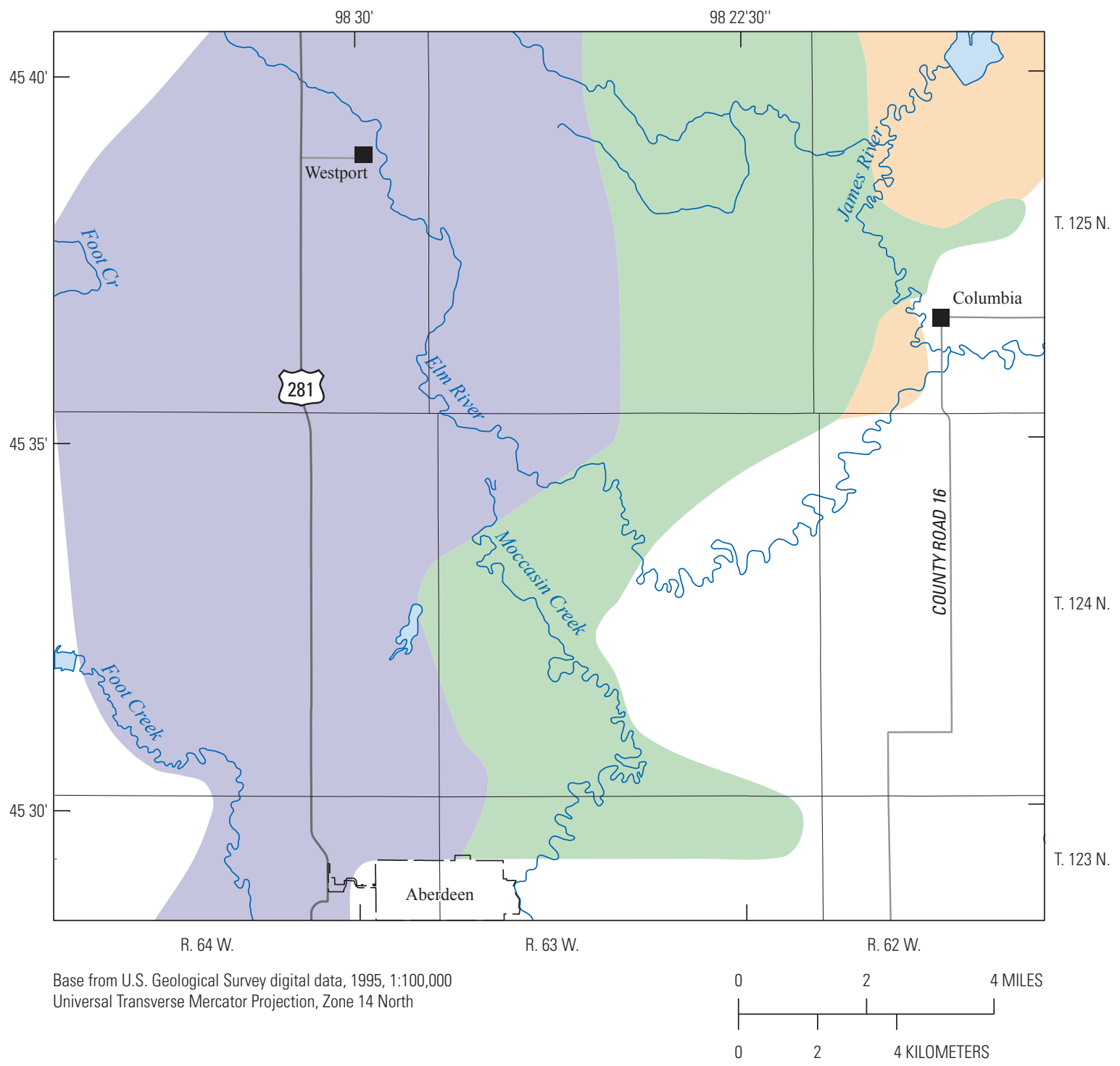

EXPLANATION

Elm aquifer

Elm aquifer overlies Middle James aquifer

Middle James aquifer

Figure 6. The extents of the Elm and Middle James aquifers in model area (modified from Koch and Bradford, 1976). 
Recharge to the Middle James aquifer is primarily from hydraulic connection with the Elm aquifer (Koch and Bradford, 1976). Most recharge to the Deep James aquifer is from overlying aquifers, where they are hydraulically connected (Emmons, 1990).

Natural discharge from the Elm aquifer is from evapotranspiration, seepage into the Elm River and Foot Creek, hydraulic connection to the Middle James aquifer, and flow into lacustrine deposits in the Lake Dakota Plain (Koch and Bradford, 1976). Discharge from the Middle James aquifer is by percolation to the Deep James aquifer and flow into Lake Dakota sediments and till. Discharge from the Deep James aquifer is by upward leakage through till to overlying aquifers.

The general direction of groundwater movement in the Elm aquifer in the model area is from northwest to southeast and toward the Elm River and Foot Creek (Koch and Bradford, 1976). Regional simulation of groundwater flow in the model area in the Middle James aquifer indicated flow from the northwest to the southeast (Emmons, 1990). Data describing groundwater flow in the Deep James aquifer were sparse; however, simulated hydraulic heads in the Deep James aquifer in northeastern Brown County (Emmons, 1990) indicated a fairly flat potentiometric surface in the model area.

\section{Conceptual Model of Glacial Aquifer System}

The conceptual model describes the overarching hydrogeologic framework, groundwater flow, hydraulic properties, and water budget components of the glacial aquifer system. The hydrogeologic framework describes the physical dimensions and location of the sand and gravel units that lie within the glacial deposits. The aquifer units are separated and overlain by glacial till, although windows (areas of missing confining material) may exist in some areas. Groundwater flow generally is to the southeast in the Elm and Middle James aquifers, but is not well known for the Deep James aquifer. The aquifers are relatively transmissive where glacial outwash sand and gravel is well sorted compared to the lower transmissivity in the glacial till and outwash with interbedded clay layers. Recharge and evapotranspiration are the major water budget components. Interaction with incised streams exists where intervening glacial till is relatively thin.

\section{Hydrogeologic Framework}

Lithologic information from the South Dakota Geological Survey (2008) was compiled in a geographic information system (GIS) database for the study area (fig. 7) to interpret the hydrogeologic framework. Electromagnetic (Supplement 1) and direct-current (Supplement 2) geophysical surveys were used as an aid in interpreting the hydrogeology. Direct-current electrical resistivity surveys provided information on the depth to the top of the Elm aquifer and the approximate thickness of the aquifer along the survey lines. Some surveys were correlated with lithologic logs, which provided hydrogeologic references for data from other surveys where no wells or test holes had been drilled. The approximate top and bottom altitudes of the Elm aquifer from the center of a geophysical survey were entered in the GIS database for areas where no other aquifer depth and thickness data were available. Surfaces and spatial datasets were interpolated from the GIS database that physically describe the altitudes of the land surface (fig. 4); thickness of the glacial till overlying the Elm aquifer; top and bottom of the Elm, Middle James, and Deep James aquifers; and thickness of confining layers. The interpolated files were compared with the electromagnetic and direct-current geophysical surveys, as well as lithologic logs through cross-sections, to ensure that the interpolated surfaces were reasonable.

The top of each aquifer was defined as the uppermost sand or gravel unit listed in the lithologic log that was within the altitude range of that aquifer. Koch and Bradford (1976) defined the altitude ranges as 1,400 to $1,225 \mathrm{ft}$ for the Elm aquifer; 1,250 to $1,150 \mathrm{ft}$ for the Middle James aquifer; and 1,175 to $950 \mathrm{ft}$ for the Deep James aquifer. The bottom of each aquifer was defined as the lowest extent of sand or gravel in the lithologic log that was within the altitude range of the aquifer. When sand and gravel units were absent within an aquifer range, the thickness within the aquifer range was included in the confining layers. This arbitrary datum for each aquifer allowed referencing of the lithologic logs necessary to provide information on the presence and absence of the aquifer during interpolation.

The interpreted boundaries for the Middle James and Deep James aquifer were constrained by the bedrock topography (figs. 7 and 8). The eastern boundary for the Elm aquifer was defined by the James River, which is at the lowest altitude (fig. 4) in the study area. Assumed groundwater flow pathways converged on the low area, with the primary discharge being to evapotranspiration and no flow across the boundary at the low area. In the southeastern part of the model area, the Elm aquifer boundary was set at low areas west of the James River (fig. 4) where flow across the boundary was assumed to be negligible. The boundary of the eastern extent of the Middle James aquifer was assumed to be similar to the Elm aquifer boundary because of the hydraulic connection to the Elm aquifer (fig. 8).

The thickness of glacial till overlying the Elm aquifer in the study area ranged from 0 to about $156 \mathrm{ft}$, with a mean thickness of about $30 \mathrm{ft}$ (fig. 9). Approximately 14 percent of the aquifer is overlain by till thicker than $50 \mathrm{ft}$ and about 4 percent is overlain by till thicker than $70 \mathrm{ft}$. The top of the Elm aquifer was interpreted to be the first substantial sand and gravel layer that was listed in the lithologic log and that was within the altitude range of that aquifer. 


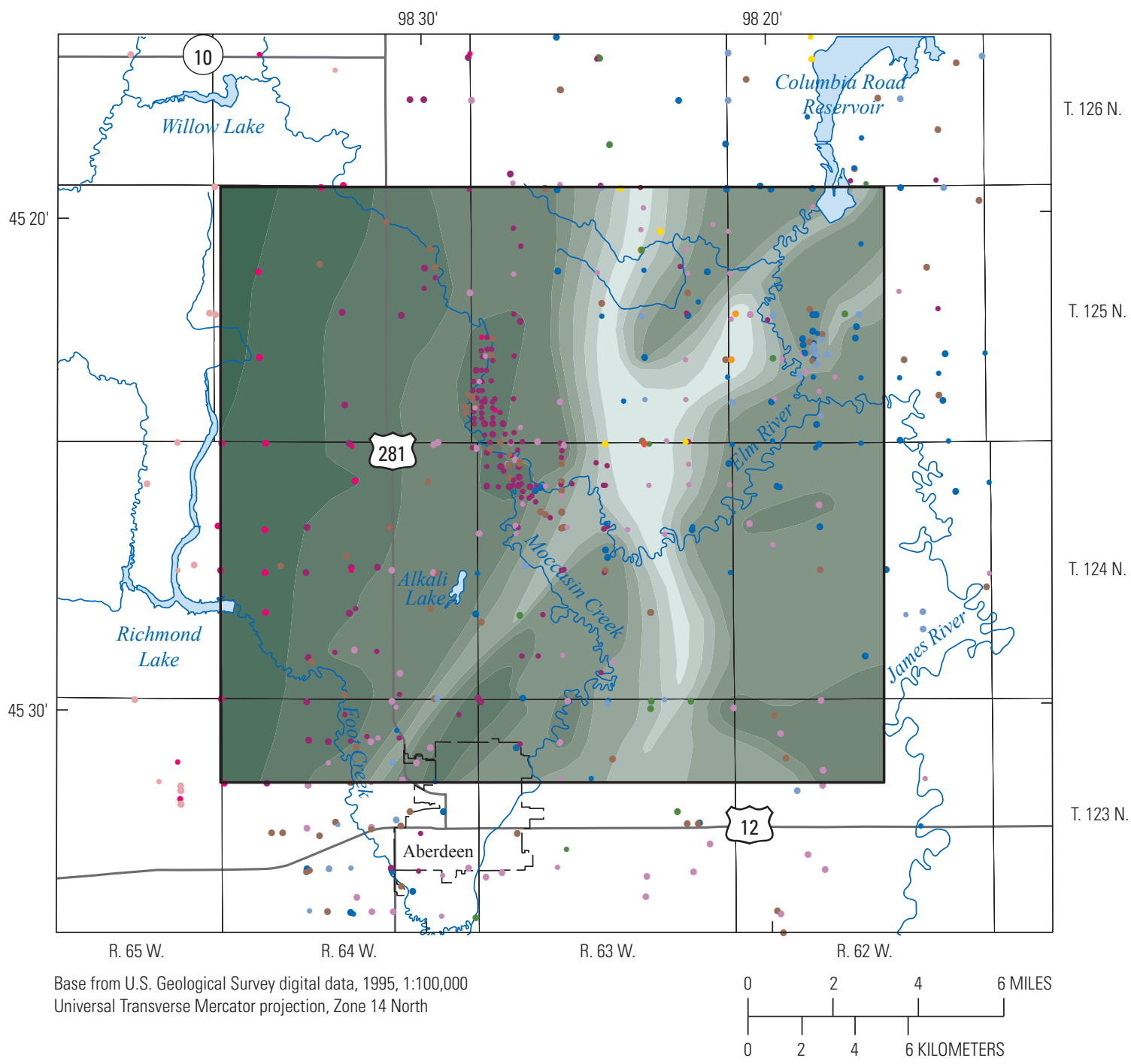

\section{EXPLANATION}

[Datum is North American Vertical Datum of 1988]

Altitude of bedrock, in feet

1,000

1,001 to 1,050

1,051 to 1,100

1,101 to 1,150

1,151 to 1,200

1,201 to 1,250

1,251 to 1,300

1,301 to 1,350

1,351 to 1,400

Extent of model area

\section{Lithologic log of bedrock altitude, in feet}

- Shallow well, bedrock not penetrated

- Less than 950

- $\quad 951$ to 1,000

- 1,001 to 1,050

- 1,051 to 1,100

- 1,101 to 1,150

- 1,151 to 1,200

- 1,201 to 1,250

- 1,251 to 1,300

- 1,301 to 1,350

- 1,351 to 1,400 in explanation.
NOTE: Smaller points indicate the maximum possible bedrock altitude based on the depth penetrated by the test hole or well. The color scheme is identical to that shown

Figure 7. Location of lithologic logs used in interpretation of hydrogeologic framework in study area and map of bedrock surface in model area. 


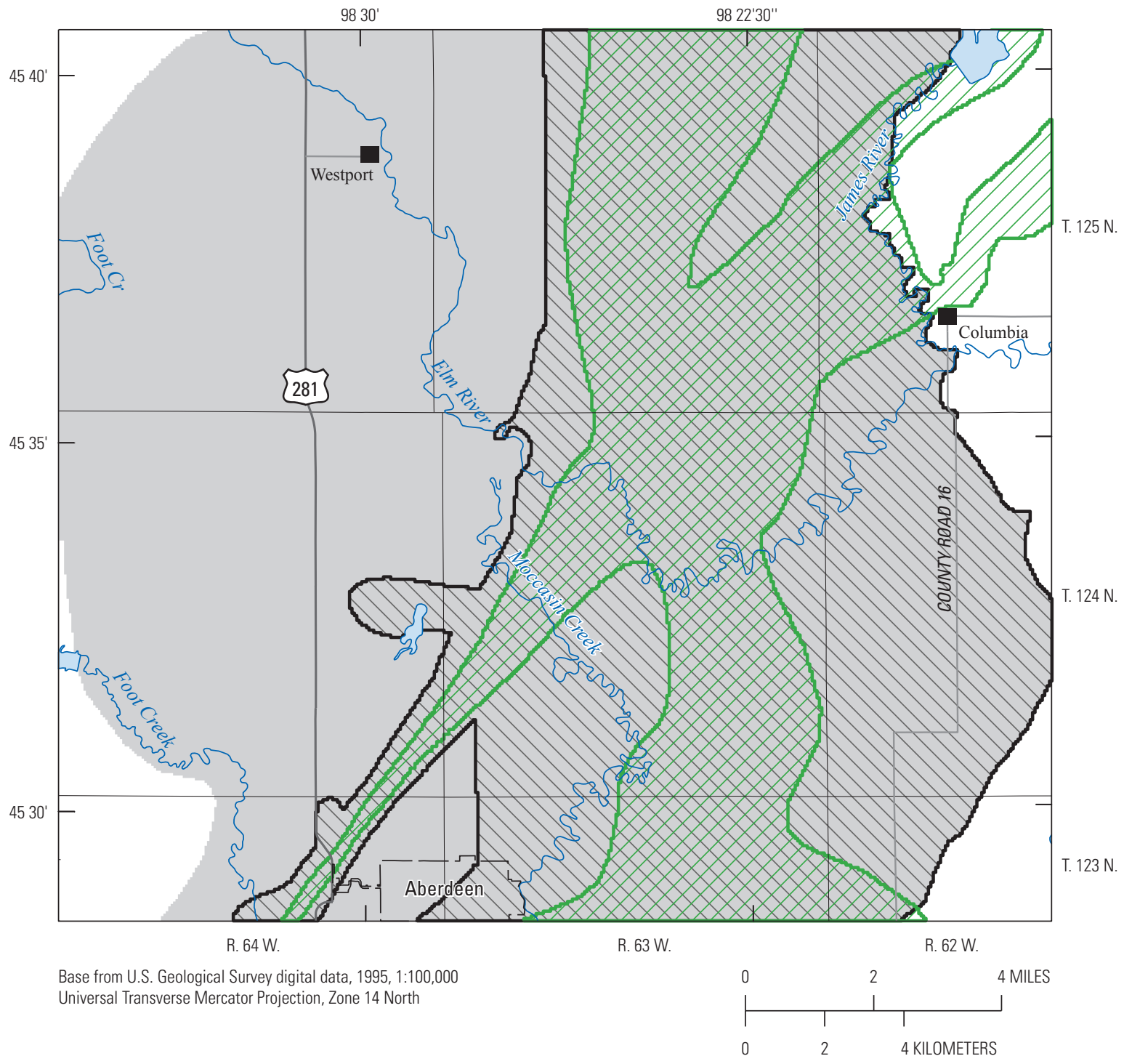

EXPLANATION

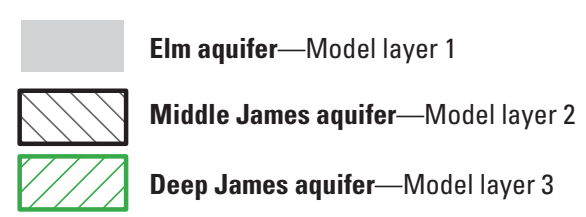

Figure 8. Glacial aquifer boundaries in model area. 


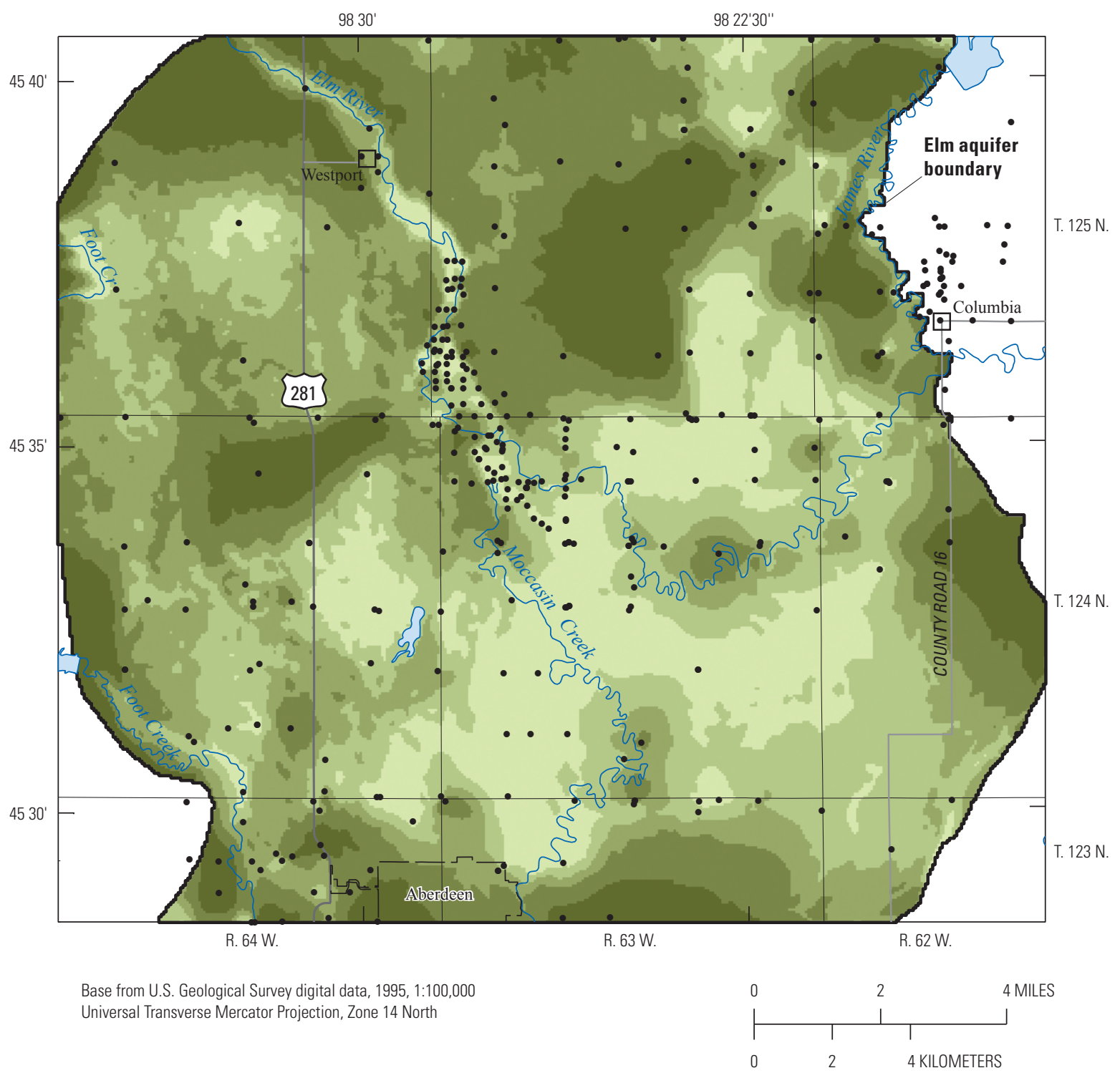

\section{EXPLANATION}

Thickness of glacial till overlying the Elm aquifer, in feet

\begin{tabular}{|l|l|}
\hline 0 to less than 10 \\
10 to less than 20 \\
20 to less than 30 \\
30 to less than 50 \\
50 to less than 156 \\
\hline
\end{tabular}

- L Lithologic log where top of Elm aquifer was identified

Figure 9. Thickness of glacial till overlying the Elm aquifer in model area. 


\section{Elm Aquifer}

The top of the Elm aquifer was identified in 319 lithologic logs from locations within the model area and was interpolated between the test hole and well locations. The saturated sandy units within the Lake Dakota Plain were included in the Elm aquifer for modeling purposes because of the hydraulic connection between the aquifer and the lacustrine deposits underlying the Lake Dakota Plain. The thickness of the Elm aquifer ranges from less than 1 to $95 \mathrm{ft}$, with an average thickness of about $24 \mathrm{ft}$ in the model area (fig. 10). The sand and gravel within the Elm aquifer has a maximum thickness of $93 \mathrm{ft}$ and an average thickness of about $20 \mathrm{ft}$ in the model area (fig. 11). About 80 percent of the material composing the Elm aquifer is sand and gravel. Most of the lithologic logs listed interbeds of finer material with thicknesses of 1 to $10 \mathrm{ft}$. In the northwestern part of the model area, the Elm aquifer has upper and lower sand and gravel deposits separated by a till zone about 20 to $40 \mathrm{ft}$ thick.

The combined thickness of sand and gravel in the Elm aquifer is large in areal extent along the Elm River in the central part of the model area. This area corresponds to the Elm River meltwater channel. The northwestern part of T. $125 \mathrm{~N}$. and R. $63 \mathrm{~W}$., and the center of T. $124 \mathrm{~N}$. and R. $64 \mathrm{~W}$. of figure 11, show areas with greater thickness of sand and gravel as well; however, relatively few lithologic logs were available for the interpolation in these locations. Thus, the extent may be overestimated in these areas.

The top of the Elm aquifer is highest in the northwestern part of the model area and generally decreases in altitude toward the southeast (fig. 12). The aquifer is thin or commonly absent where the altitude of the top of the aquifer is less than $1,240 \mathrm{ft}$. The aquifer is characterized as being relatively thin at the boundary near the eastern perimeter in the area near the James River, which is expected to preclude groundwater flow in this area. The Elm aquifer is confined in some areas by the overlying glacial till and is unconfined where the overlying glacial till is absent or the hydraulic head is below the altitude of the top of the Elm aquifer.

\section{Middle James Aquifer}

The top and bottom surfaces of the Middle James aquifer were interpolated from the lithologic data available for 192 wells and test holes (fig. 13). Additionally, the bedrock contour map of Leap (1986) was used to constrain the aquifer extent in areas not covered by lithologic data. The Middle James aquifer exists primarily in the eastern one-half of the model area and ranges in thickness from less than 1 to $91 \mathrm{ft}$, with an average thickness of $13 \mathrm{ft}$ in the model area (fig. 13). The areas where the Middle James aquifer is thickest are in southeastern T. $125 \mathrm{~N}$ and R. $63 \mathrm{~W}$ and directly east and west of Aberdeen (fig. 13). These areas become smaller in spatial extent when only the thickness of sand and gravel is considered (fig. 14). The maximum thickness of combined sand and gravel in the Middle James aquifer is $84 \mathrm{ft}$ and the average thickness is $9.5 \mathrm{ft}$. Sand and gravel make up an average of 68 percent of the thickness of the Middle James aquifer, and the remaining 32 percent is predominantly clay. The Middle James aquifer is confined by the overlying glacial till.

The hydraulic connection between the Elm aquifer and the Middle James aquifer is limited by glacial till separating the aquifers (fig. 15). The average thickness of till that makes up the confining layer between the aquifers was $56 \mathrm{ft}$ and the maximum thickness was $125 \mathrm{ft}$. Two lithologic logs near the western boundary of the Middle James aquifer indicated that no glacial till separated the Elm and Middle James aquifers. These windows in the confining layer can have a strong effect on groundwater flow and they could exist in areas that were not identified because of sparse lithologic logs. The lithologic $\log$ (table 1) for well site A-3 (fig. 15) shows a confining layer of about $3 \mathrm{ft}$. Hydrographs of continuous hydraulic head data for nested wells A-3 (screened 62-72 ft below land surface) and A-4 (screened 28-38 ft below land surface) show similar responses to aquifer inputs and stresses indicating a strong hydraulic connection between the aquifers at this location (fig. 16).

Table 1. Lithologic log for well A-3.

[Dashed lines separate hydrogeologic units. U.S. Geological Survey station number 453359098260101]

\begin{tabular}{cll}
\hline $\begin{array}{c}\text { Depth below } \\
\text { land surface } \\
\text { (feet) }\end{array}$ & \multicolumn{1}{c}{ Description } & Hydrogeologic unit \\
\hline $0-1$ & Topsoil, black & Topsoil \\
$1-15$ & Sand and gravel, brown & \\
$15-25$ & Clay, gray & \\
$25-39$ & Sand and gravel & \\
$39-41$ & Clay gray & \\
$41-54$ & Sand and gravel, some coal & \\
$54-57$ & Clay, gray & \\
$57-60$ & Sand and gravel, some coal & \\
$60-62$ & Clay, gray \\
$62-69$ & Sand and gravel; some layers & \\
& of clay and coal \\
$69-71$ & Clay, gray \\
$71-73$ & Gravel \\
$73-74$ & Clay, gray \\
$74-82$ & Gravel and sand \\
$82-85$ & Clay, gray \\
$85-107$ & Sand and gravel, clayey & \\
\hline
\end{tabular}




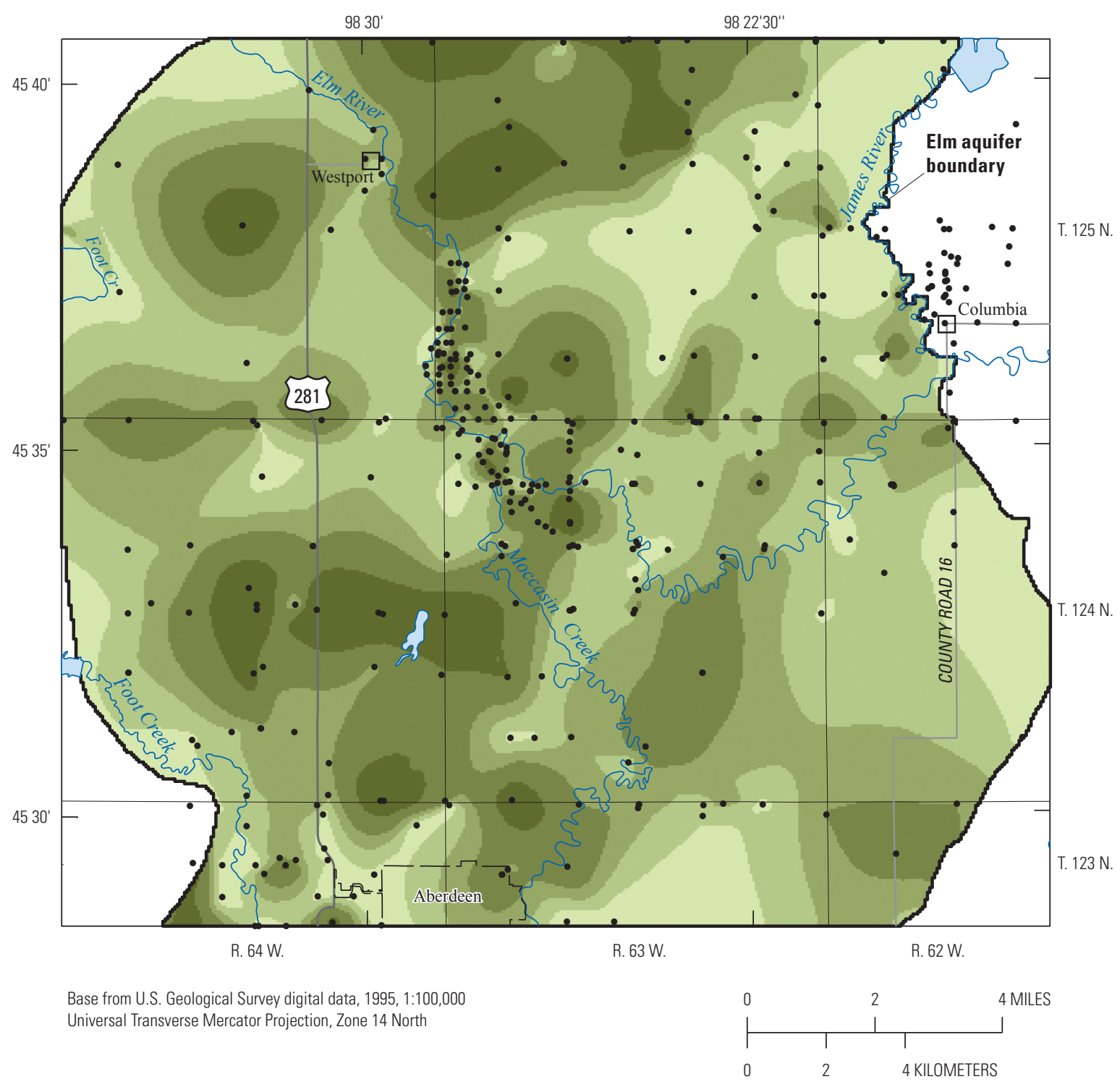

EXPLANATION

Thickness of Elm aquifer, in feet

Less than 10

10 to less than 20

20 to less than 30

30 to less than 50

50 to 95

Lithologic log where Elm aquifer is known to be present or absent

Figure 10. Thickness of the Elm aquifer in model area. 


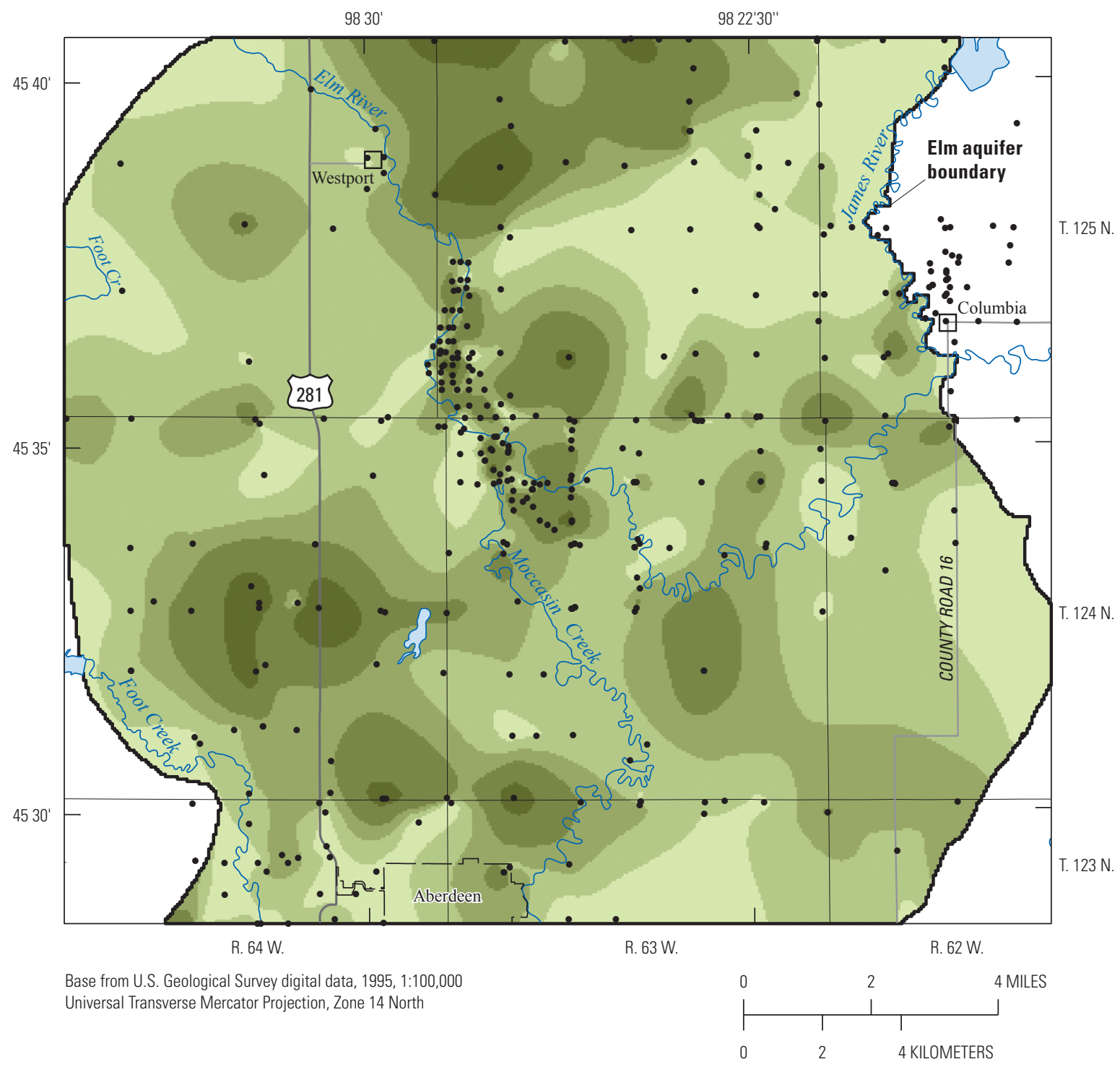

\section{EXPLANATION}

Thickness of sand and gravel deposits within the Elm aquifer, in feet

Less than 10

10 to less than 20

20 to less than 30

30 to less than 50

50 to 93

- Lithologic log where Elm aquifer is known to be present or absent

Figure 11. Combined thickness of sand and gravel deposits within the Elm aquifer in model area. 


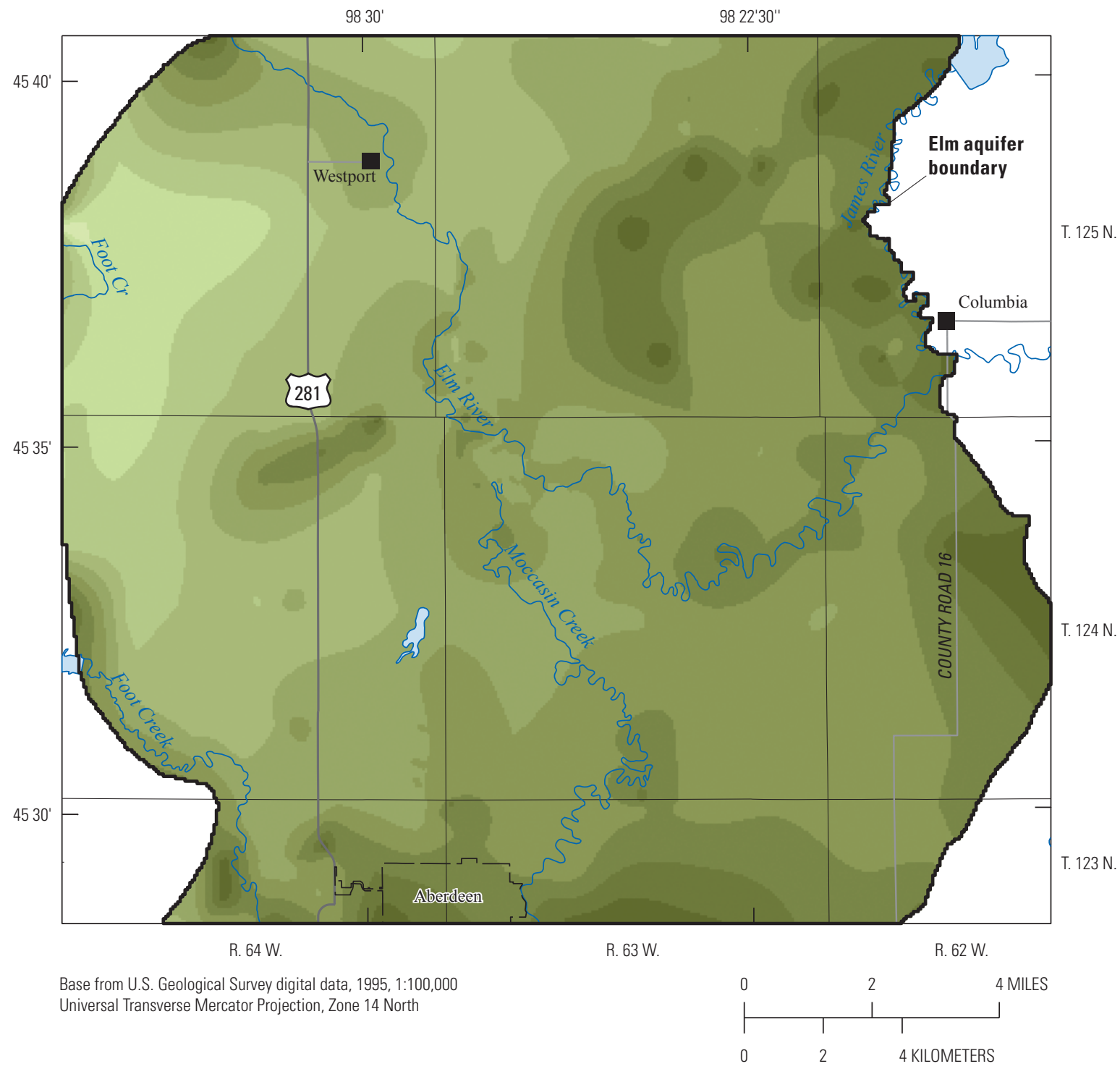

EXPLANATION

Altitude of Elm aquifer top, in feet

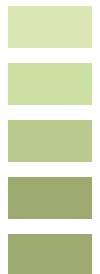

\begin{tabular}{l|l|l|}
\hline 1,381 to 1,400 & 1,281 to 1,300 \\
1,361 to 1,380 & 1,261 to 1,280 \\
1,341 to 1,360 & 1,241 to 1,260 \\
1,321 to 1,340 & 1,225 to 1,240 \\
1,301 to 1,320 &
\end{tabular}

Figure 12. Altitude of the top of the Elm aquifer in model area. 


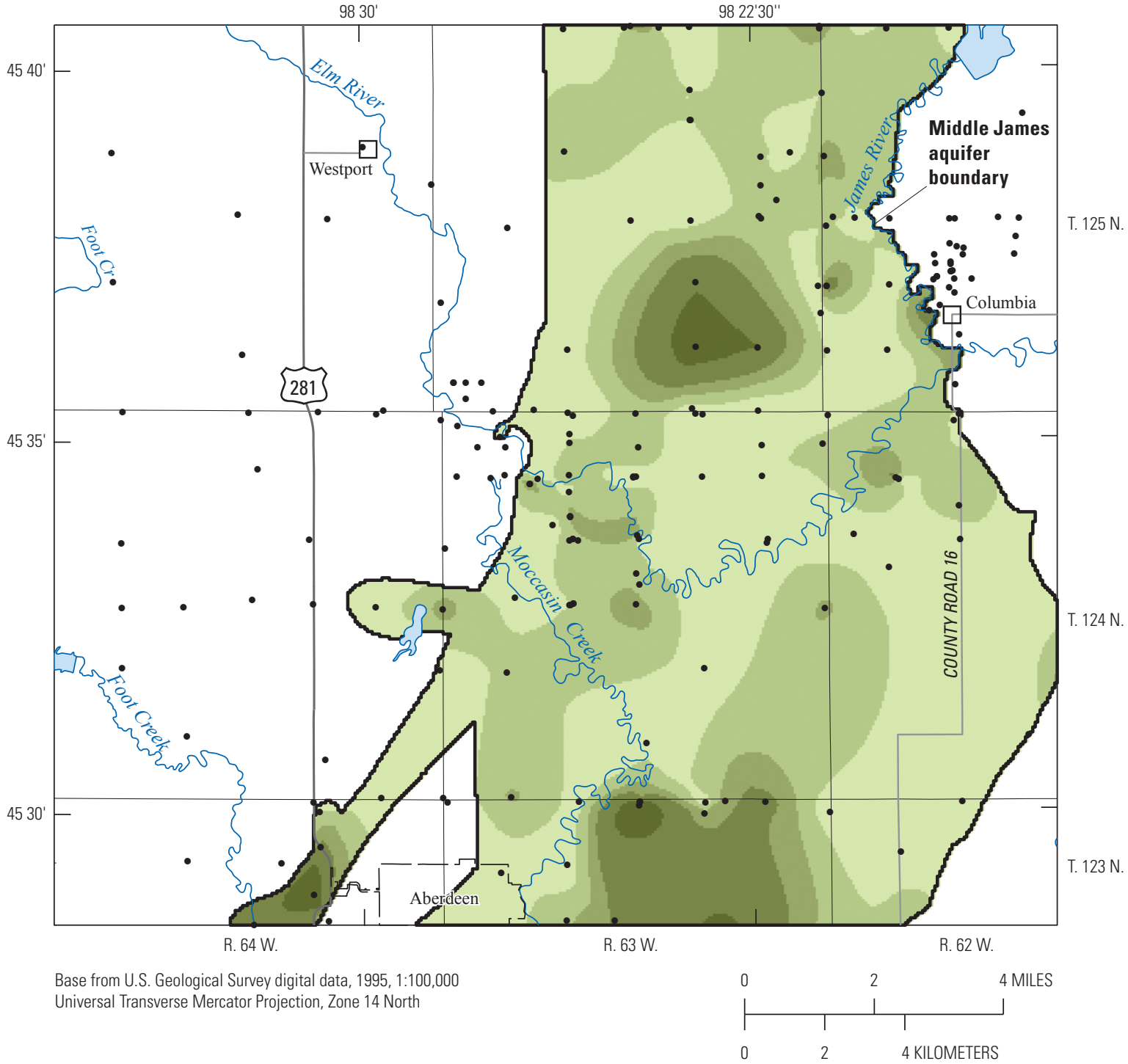

\section{EXPLANATION}

Thickness of the Middle James aquifer, in feet

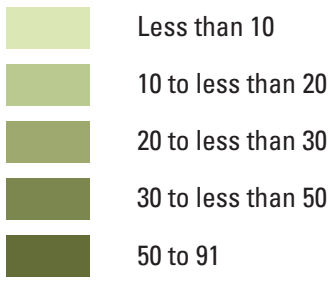

- $\quad$ Lithologic log where thickness of the Middle James aquifer is known

Figure 13. Thickness of the Middle James aquifer in model area. 


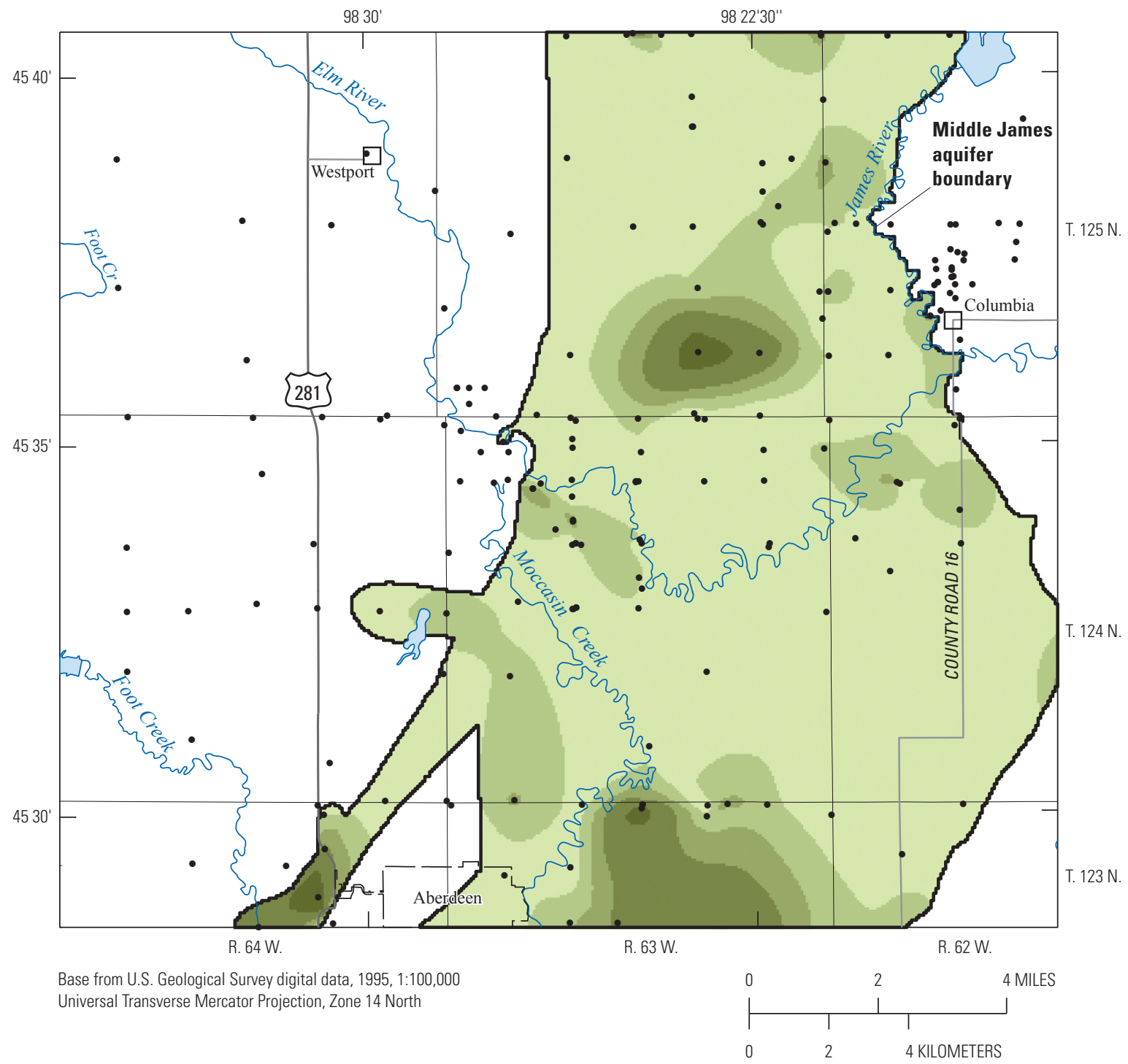

EXPLANATION

Thickness of sand and gravel deposits within the Middle James aquifer, in feet

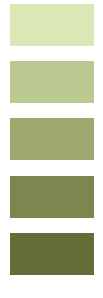

Less than 10

10 to less than 20

20 to less than 30

30 to less than 50

50 to 84

- Lithologic log where thickness of the Middle James aquifer is known

Figure 14. Combined thickness of sand and gravel deposits within the Middle James aquifer. 


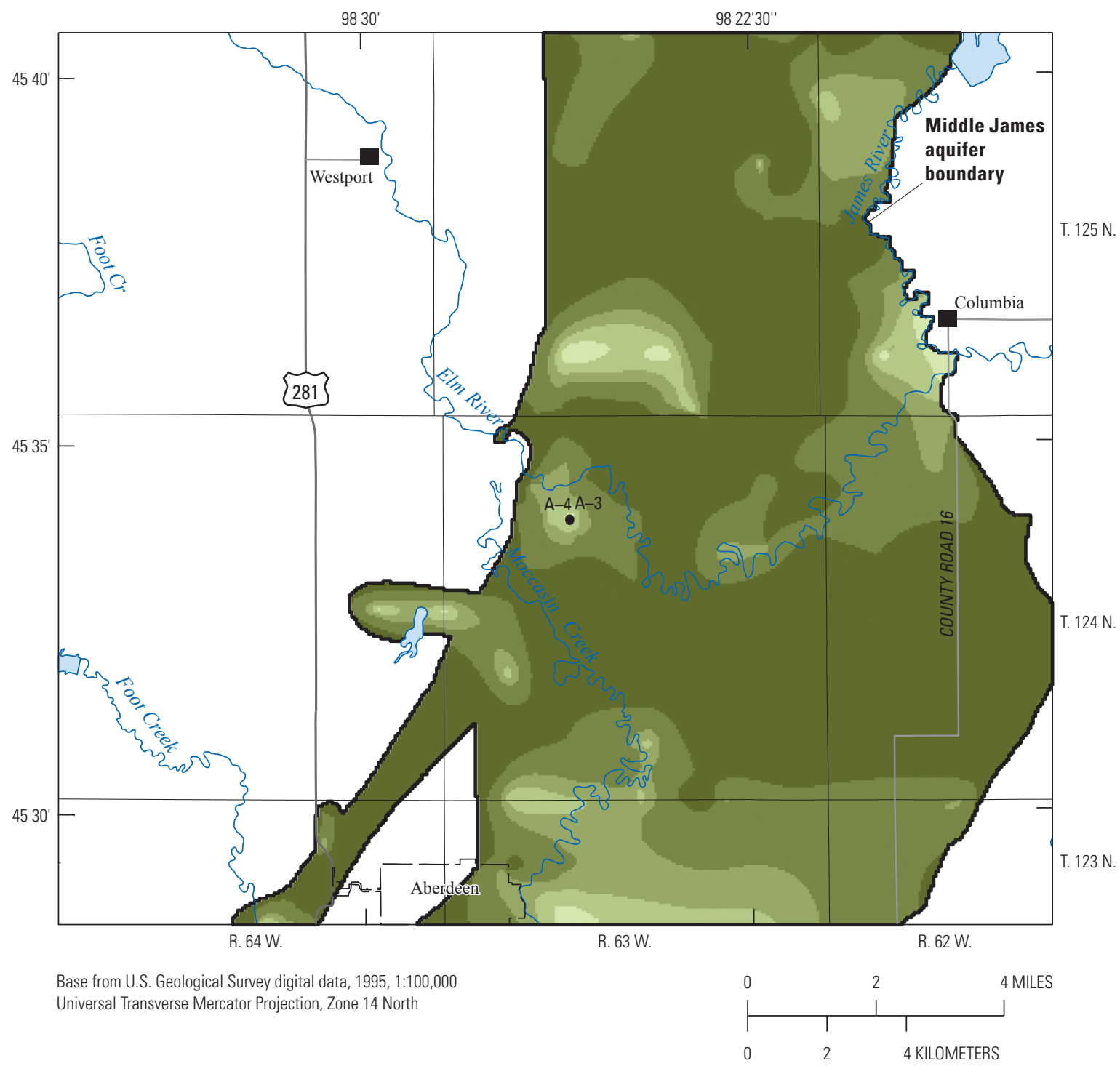

EXPLANATION

Thickness of confining layer 1 , in feet

Less than 10

10 to less than 20

20 to less than 30

30 to less than 50

50 to 125

A-4 Well site with site identifier

Figure 15. Thickness of confining layer 1 in model area. 


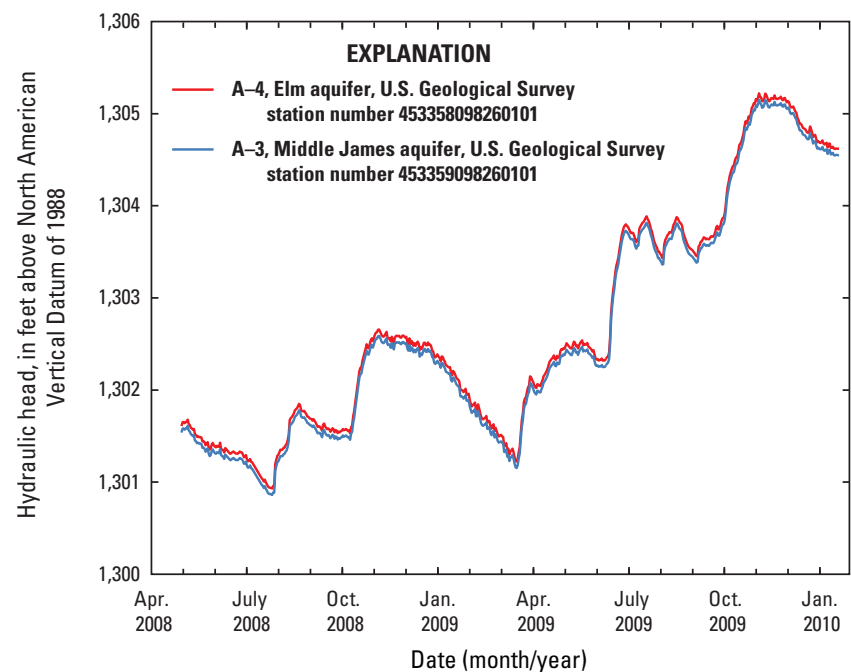

Figure 16. Hydraulic heads for nested wells $A-3$ and A-4. (Data from U.S. Geological Survey, 2010.)

\section{Deep James Aquifer}

The extent and thickness of the Deep James aquifer initially were determined by using the bedrock contour map produced by Leap (1986), which was modified by using the lithologic logs for 29 test holes (fig. 17). Using the representation shown in figure 17, the Deep James aquifer is less than 1 to $165 \mathrm{ft}$ thick in the model area and has an average thickness of $23 \mathrm{ft}$ based on the interpolation. The average percentage of sand and gravel deposits in the Deep James aquifer was estimated to be about 70 percent. The till between the Middle James and Deep James aquifers had a maximum thickness of $280 \mathrm{ft}$ and an average thickness of $150 \mathrm{ft}$. The lithologic logs with data describing the Deep James aquifer were typically a few thousand feet to several miles from the closest lithologic log in any given direction. The great distance between some wells, particularly in T. $124 \mathrm{~N}$ and R. $63 \mathrm{~W}$, prevented characterization of the aquifer with a high degree of certainty. The differences between lithologic logs at wells 124N63W03AAAB and 124N63W02BBBB demonstrate the variability in the presence and thickness of the Deep James aquifer (fig. 17). At well 124N63W03AAAB, the total thickness of sand and gravel deposits is $12 \mathrm{ft}$; however, the total thickness of sand and gravel at well 124N63W02BBBB, located $176 \mathrm{ft}$ away, is $82 \mathrm{ft}$ (fig. 17). The Deep James aquifer is confined by the overlying glacial till.

\section{Groundwater Flow}

Water-level data for 91 wells completed in the Elm aquifer were used to interpolate a generalized average potentiometric surface in the model area (fig. 18). Water-level data and associated land-surface altitudes were used to calculate hydraulic heads and generate a map of the estimated average potentiometric surface (1975-2009). The average hydraulic heads for sites with a single water-level measurement that was made within the 1975-2009 period, were estimated through comparison with nearby observation wells that had long-term records (fig. 18). The hydraulic head was adjusted up or down on the basis of the change in hydraulic head from average at the selected long-term wells. The measured water-level date, altitude, and estimated average water-level altitude are listed in table S7-1. The ranges in the measured water levels in feet for the seven observation wells with records for 1975-2009 were 8.3 (site 10), 10.3 (site 11), 15.8 (site 21), 20.6 (site 23), 15.1 (site 41), 8.2 (site 73), and 15.5 (site 86).

Single water-level measurements at 43 of 91 sites were made prior to 1975. Although these water-levels were made outside the period represented, they were used to estimate the generalized potentiometric surface in areas where no other data existed. The cumulative departure of monthly precipitation from average (1931-2009) (fig. 2) was used as a guide in estimating an average water level for these sites. For example, to estimate the average water level for 1975-2009, the water level for site 88 measured in 1949 was adjusted down $6 \mathrm{ft}$ on the basis of the above average precipitation in the 1940s and a comparison to relative water-level changes at nearby site 86 that had a long-term record (fig. 18; table S7-1). Changes made in the estimated average water levels for these sites in comparison to the measured water levels was limited to $6 \mathrm{ft}$ or less, which was about 50 percent of the average water-level fluctuation for the long-term observation wells. These small adjustments in the water levels with measurement dates prior to 1975 were made to produce a smoothed generalized average potentiometric surface (1975-2009).

Groundwater flow in the Elm aquifer generally is to the southeast, following the topography and toward the Lake Dakota Plain where evapotranspiration is a substantial sink (fig. 18). The Elm River, Foot Creek, and Moccasin Creek have gaining reaches, as evidenced by the localized flow directions toward these streams.

The confined and unconfined parts of the Elm aquifer are defined on the basis of hydraulic head in relation to the altitude of the bottom of the glacial till and clay overlying the aquifer. Comparison of the estimated average potentiometric surface in the Elm aquifer with the top (fig. 12) of the Elm aquifer indicates the approximate location of confined and unconfined areas (fig. 19). In a large part of the aquifer, the generalized potentiometric surface is within $10 \mathrm{ft}$ above or below the top of the aquifer where confined or unconfined conditions could prevail depending on the local hydraulic head.

The simulated steady-state potentiometric surface for the Middle James aquifer (Emmons, 1990) indicated that groundwater flows from the northwest to southeast (fig. 20). The hydraulic heads range from about $1,330 \mathrm{ft}$ in the northwest to $1,280 \mathrm{ft}$ in the southeast with the distribution of potentiometric contours similar to the Elm aquifer. The simulated steady-state potentiometric surface for the Deep James aquifer (Emmons, 1990) indicated a relatively flat potentiometric surface with hydraulic heads of about $1,320 \mathrm{ft}$ in the northwest to $1,290 \mathrm{ft}$ in the southeast (fig. 21). Available data were too few to characterize the potentiometric surface in the Middle James and the Deep James aquifers, so maps modified from Emmons (1990) are shown. 


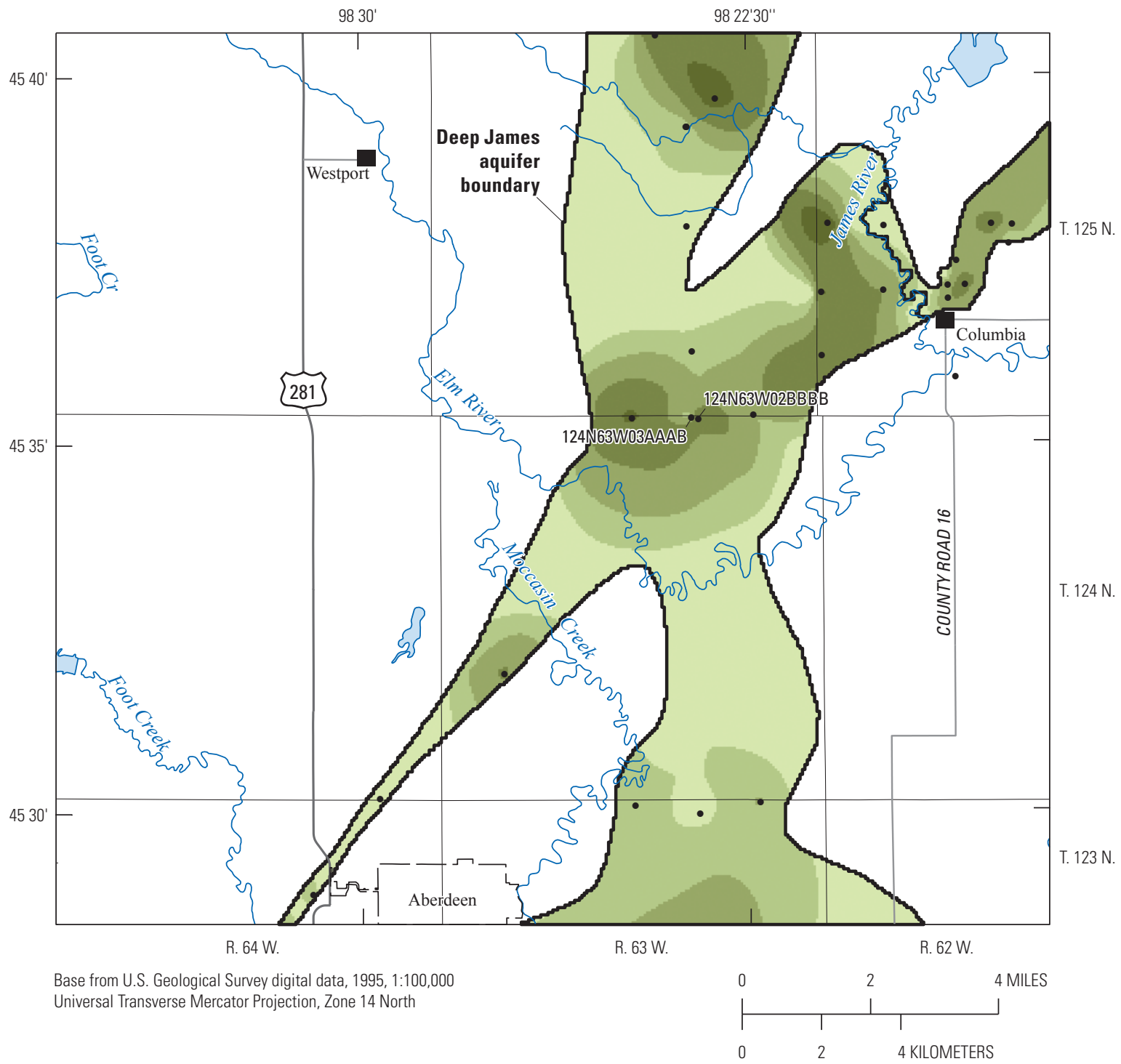

EXPLANATION

Thickness of the Deep James aquifer, in feet

Less than 10

10 to less than 25

25 to less than 50

50 to less than 100

100 to 165

- $\quad$ Test hole that penetrated the Deep James aquifer

Figure 17. Location of test holes in the Deep James aquifer and interpolated thickness in model area. 


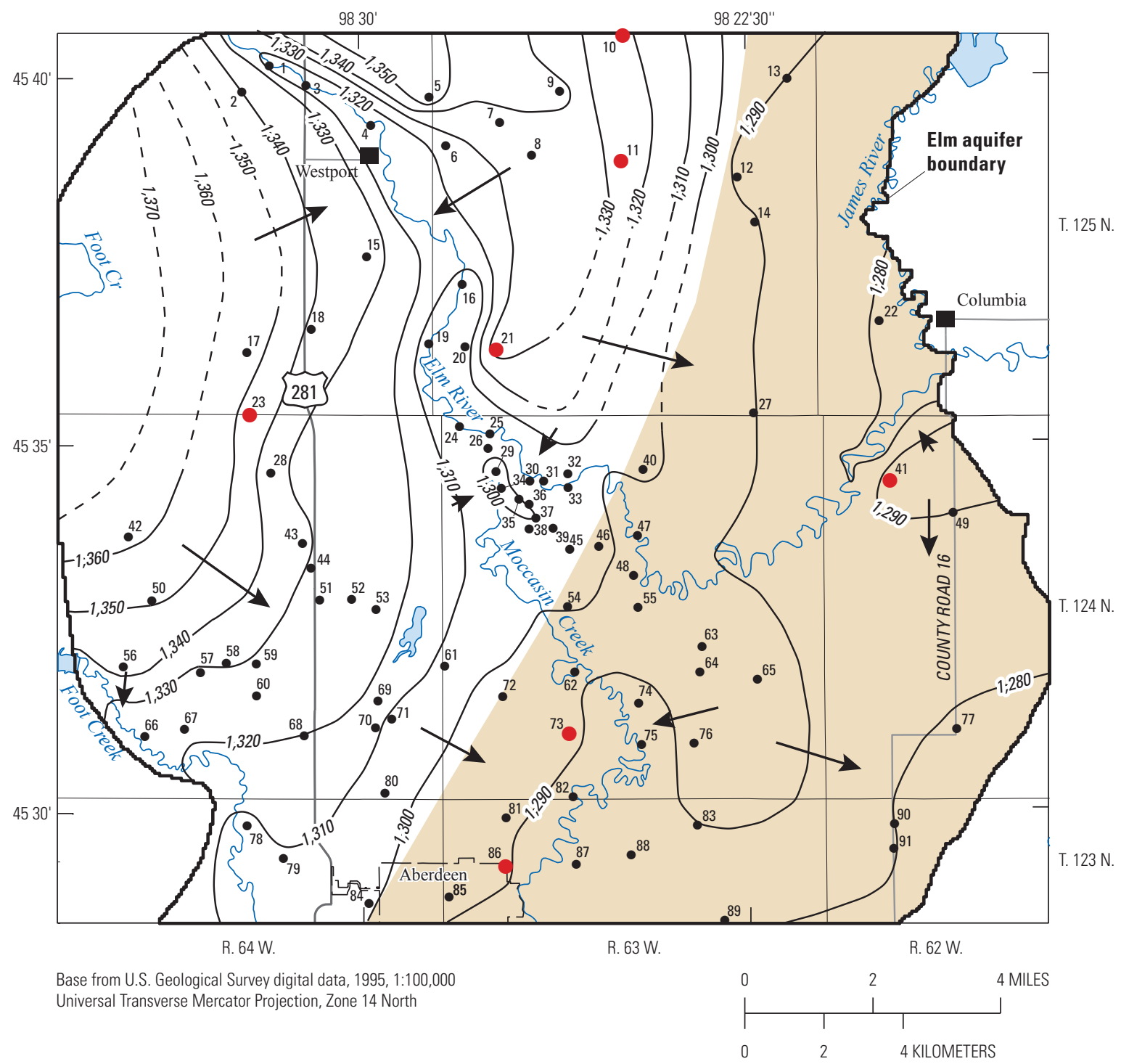

\section{EXPLANATION}

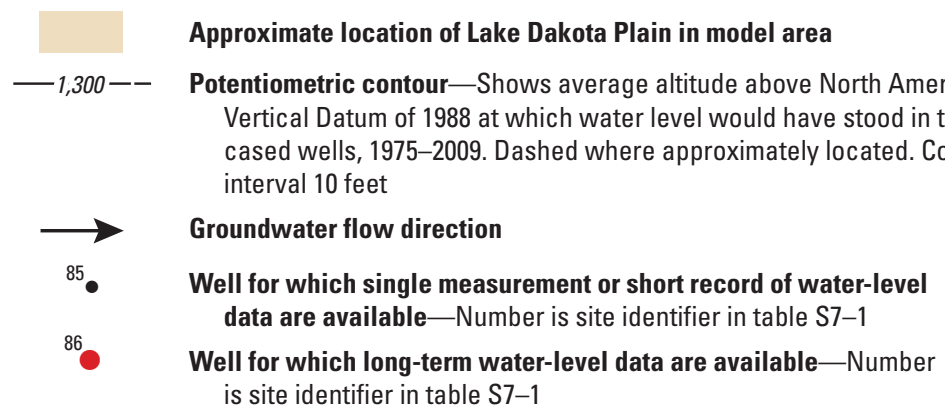

Figure 18. Generalized average potentiometric surface (1975-2009) for the Elm aquifer in model area. 


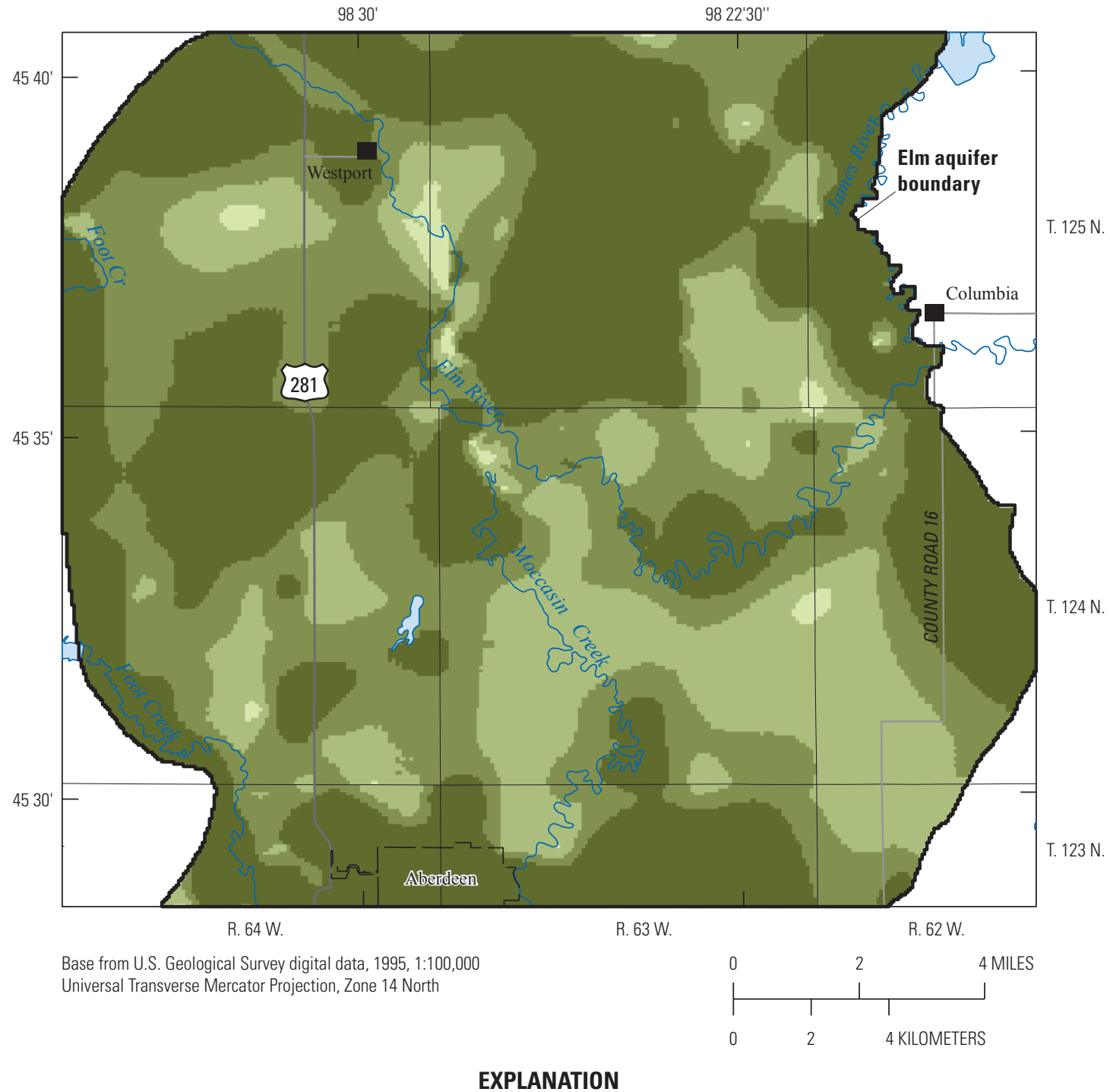

Confined-Generalized potentiometric surface greater than 10 feet above the top of the Elm aquifer

Transitional-Generalized potentiometric surface at the top of the Elm aquifer to 10 feet above

Transitional—Generalized potentiometric surface at the top of the Elm aquifer to 10 feet below

Unconfined-Generalized potentiometric surface greater than 10 feet below the top of the Elm aquifer

Figure 19. Distribution of confined and unconfined areas in the Elm aquifer in model area. 


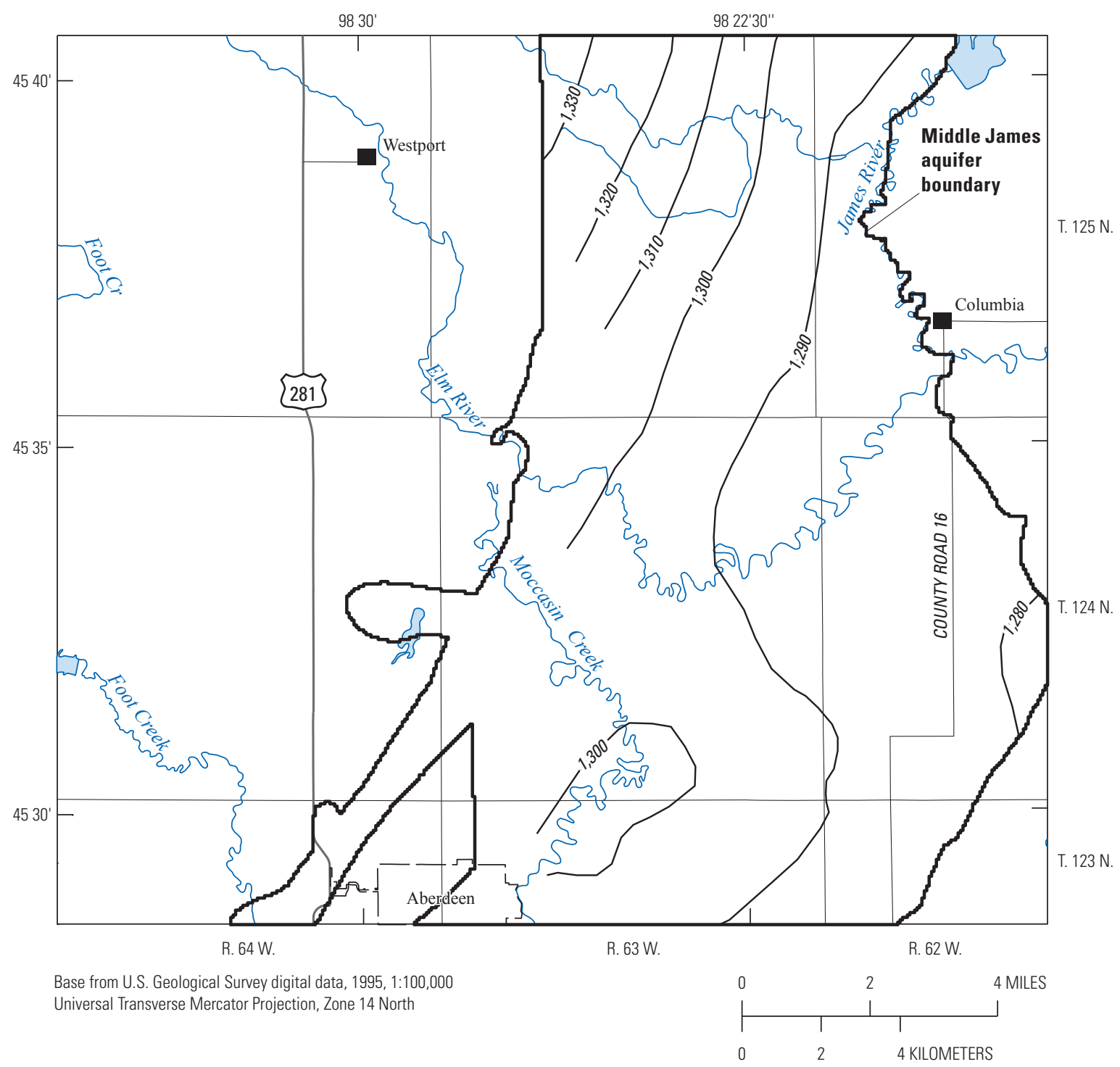

EXPLANATION

\section{- 1,300 - Potentiometric contour-Shows altitude above National Geodetic Vertical Datum of 1929 of simulated potentiometric surface on the basis of average hydrologic conditions, 1972-1982. Contour interval 10 feet. Extent of contours are within boundaries used by Emmons (1990)}

Figure 20. Simulated steady-state potentiometric surface of the Middle James aquifer (modified from Emmons, 1990). 


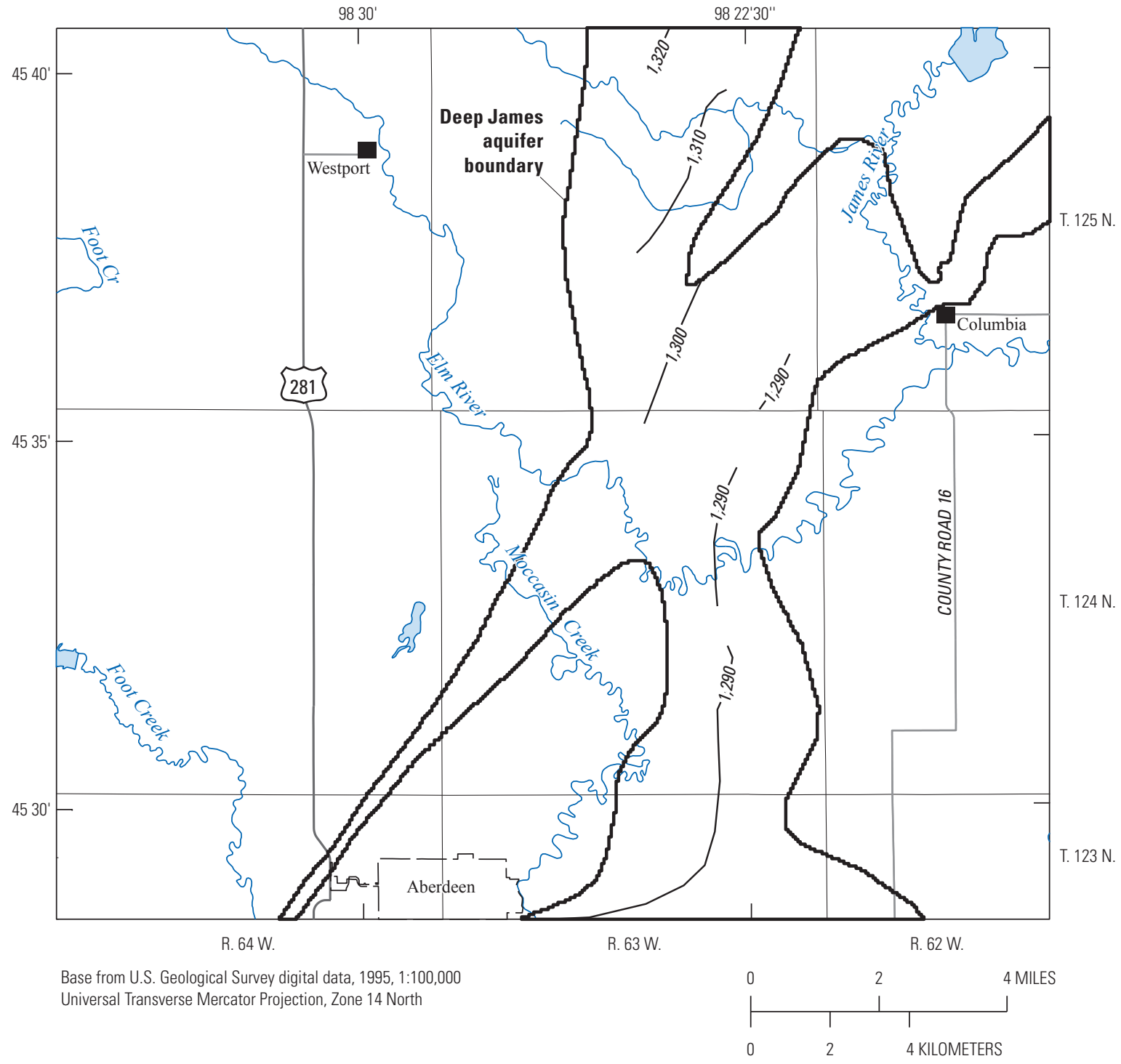

EXPLANATION

-1,300 - Potentiometric contour-Shows altitude above National Geodetic Vertical

Datum of 1929 of simulated potentiometric surface on the basis of average hydrologic conditions, 1972-1982. Contour interval 10 feet. Extent of contours are within boundaries used by Emmons (1990)

Figure 21. Simulated steady-state potentiometric surface of the Deep James aquifer (modified from Emmons, 1990). 


\section{Hydraulic Properties}

The hydraulic properties of the glacial sediments are heterogeneous and can vary over several orders of magnitude (Cowman, 1996; Davis and others, 1997; Emmons, 1990). Glacial outwash that consists of mostly sand and gravel may have horizontal hydraulic conductivity values of as much as several hundred feet per day, and glacial till may have horizontal hydraulic conductivity values several orders of magnitude less than $1 \mathrm{ft} / \mathrm{d}$. Vertical hydraulic conductivity of glacial outwash is typically much less than horizontal hydraulic conductivity because of interbedded layers of fine sediments.

\section{Horizontal Hydraulic Conductivity}

Horizontal hydraulic conductivity values used in a regional simulation of the glacial aquifers in northern Brown County (Emmons, 1988) ranged from 10-350 ft/d for the Elm aquifer, 59-350 ft/d for the Middle James aquifer, and 116-350 ft/d for the Deep James aquifer.

The horizontal hydraulic conductivity of the Elm aquifer was determined to be $418 \mathrm{ft} / \mathrm{d}$ by simulating aquifer tests, lasting 6.625 days (Supplement 3), of a sand pit that penetrated the Elm aquifer (fig. 22). Hydraulic conductivity for the Elm aquifer determined from analysis of data from seven single-well aquifer tests at production wells (fig. 22) for a 12-hour period averaged $143 \mathrm{ft} / \mathrm{d}$ with a range of $97-205 \mathrm{ft} / \mathrm{d}$ (Supplement 4).

\section{Storage Properties}

A storage coefficient of $3.0 \times 10^{-4}$ was used for all aquifers in the numerical model of the glacial aquifer system in the northern three-fourths of Brown County by Emmons (1988). The storage coefficient determined from the Eyestone Pit

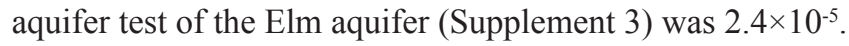
A specific yield value of 0.20 was used for the unconfined aquifer on the basis of the report by Emmons (1990).

\section{Vertical Hydraulic Conductivity}

The vertical hydraulic conductivities of the aquifer units are typically less than the horizontal hydraulic conductivities because of interbedded clay layers within the aquifer units; however, the discontinuous extent of clay units could result in a wide range of plausible values for this parameter. The interpolated confining layers from lithologic logs could represent a more continuous connection and omit unidentified windows in confining layers.

The hydraulic connection between the Elm River and Elm aquifer was investigated for the reach of the Elm River by monitoring hydraulic heads in the Elm aquifer and temperature changes in the sediments beneath the Elm River (fig. 23), which is described in Supplement 5. The estimated vertical hydraulic conductivity of the sediments ranged from 0.1 to $2.5 \mathrm{ft} / \mathrm{d}$ (table 2).

Table 2. Vertical hydraulic conductivity of sediments separating the Elm River and Elm aquifer.

\begin{tabular}{cccc}
\hline $\begin{array}{c}\text { Temperature } \\
\text { site identifier }\end{array}$ & $\begin{array}{c}\text { Adjacent } \\
\text { piezometer } \\
\text { identifier }\end{array}$ & $\begin{array}{c}\text { Thickness of } \\
\text { sediment separating } \\
\text { Elm River and } \\
\text { Elm aquifer } \\
\text { (feet) }\end{array}$ & $\begin{array}{c}\text { Vertical } \\
\text { hydraulic } \\
\text { conductivity } \\
\text { (feet per day) }\end{array}$ \\
\hline T2 & PZ8 & 17.8 & 1.0 \\
T5 & PZ1 & 9.9 & 2.5 \\
T6 & PZ3 & 6.8 & 0.1 \\
T7 & PZ6 & 6.1 & 1.3 \\
T8 & PZ7 & 11.2 & 0.3 \\
T9 & PZ9 & 16.1 & 1.6 \\
\hline
\end{tabular}

The vertical hydraulic conductivity of the glacial till is an important parameter in estimating the hydraulic connection between the glacial aquifers. Studies in counties near and surrounding Brown County demonstrate that both weathered and unweathered till have large ranges of measured vertical hydraulic conductivity, and that weathered till can have a vertical hydraulic conductivity several orders of magnitude larger than measured in unweathered till. Vertical hydraulic conductivity of glacial till measured in selected counties in eastern South Dakota (county locations shown in fig. 23) indicates a range of $1.4 \times 10^{-1}$ to $1.4 \times 10^{-5}(\mathrm{ft} / \mathrm{d})($ table 3$)$.

\section{Water Budget Components}

Given the climate and small human population in the study area, it is expected that the major water budget components are infiltration of precipitation and evapotranspiration. Discharge to streams and human water use are smaller budget components.

\section{Recharge}

The spatial and temporal distribution of recharge to the Elm aquifer was estimated using a soil-water-balance (SWB) method (Westenbroek and others, 2010) that is described in Supplement 6 . The annual recharge rate for the model area calculated using the SWB method for water year (WY) 19752009 ranged from 0.028 inch (in.) in WY 1980 to 4.52 in. in WY 1986 with an annual mean recharge rate of 1.56 in. Spatial variation in the mean annual recharge (1975-2009) ranged from 0 in clayey till areas to $23.7 \mathrm{in} / \mathrm{yr}$ in areas with coarse surficial soils (fig. 24). 


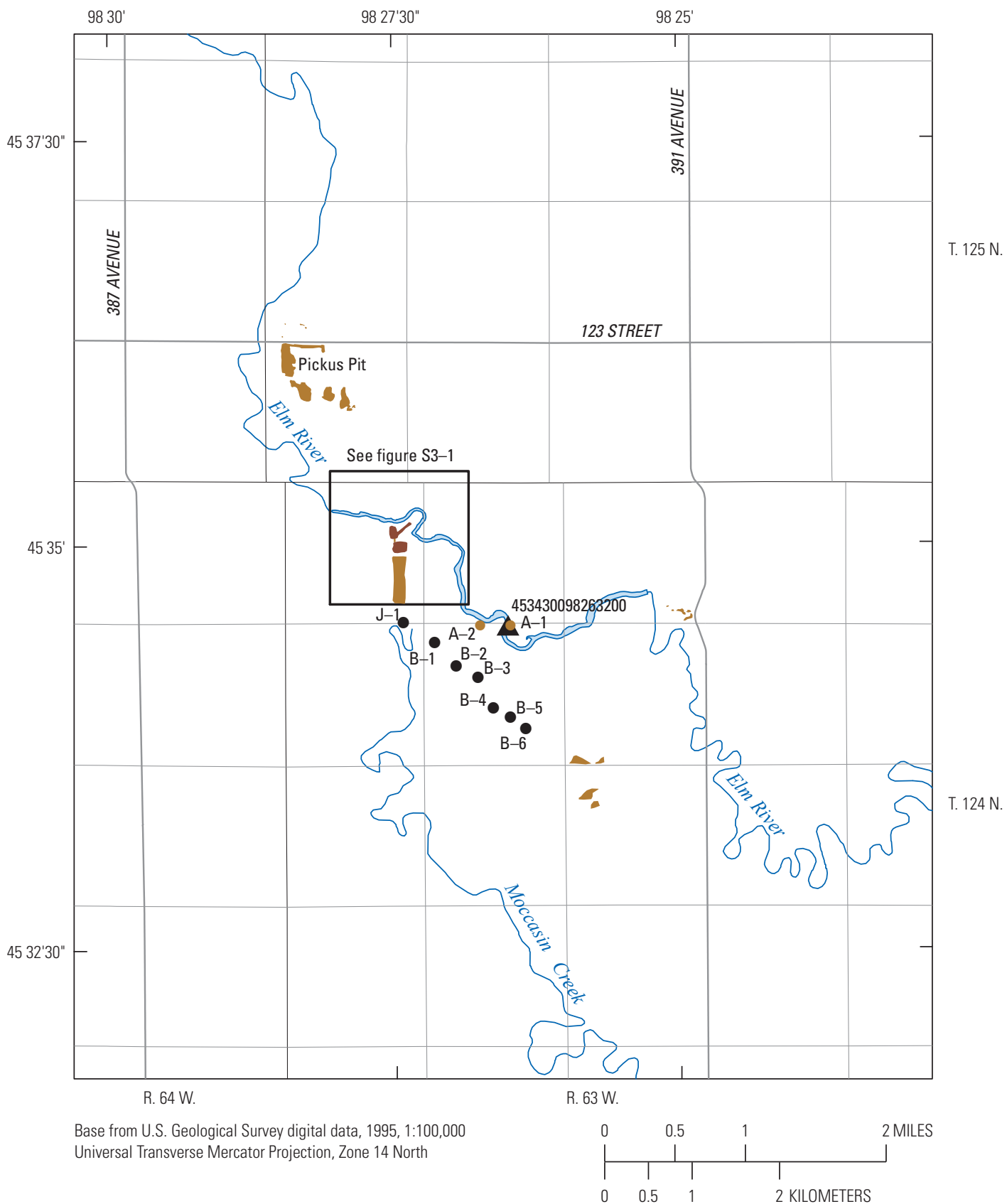

\section{EXPLANATION}

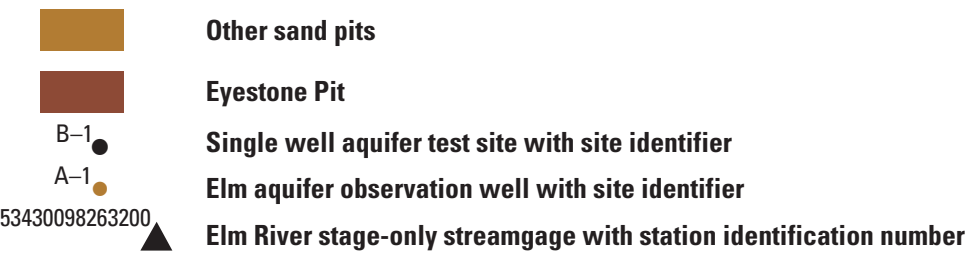

Figure 22. Location of aquifer test sites and selected hydrologic features. 


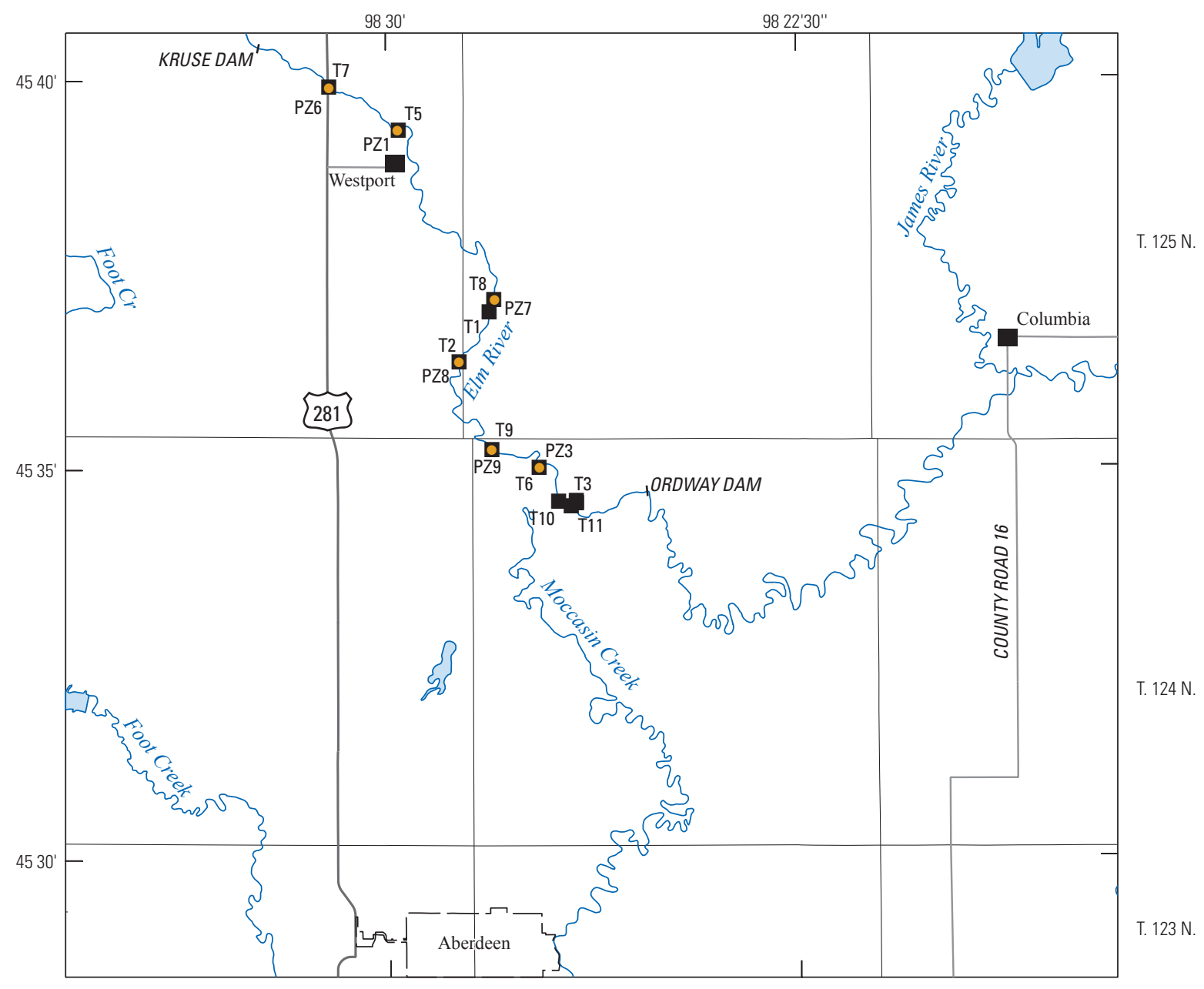

R. 64 W.

R. $63 \mathrm{~W}$.

R. 62 W.

Base from U.S. Geological Survey digital data, 1995, 1:100,000 Universal Transverse Mercator Projection, Zone 14 North
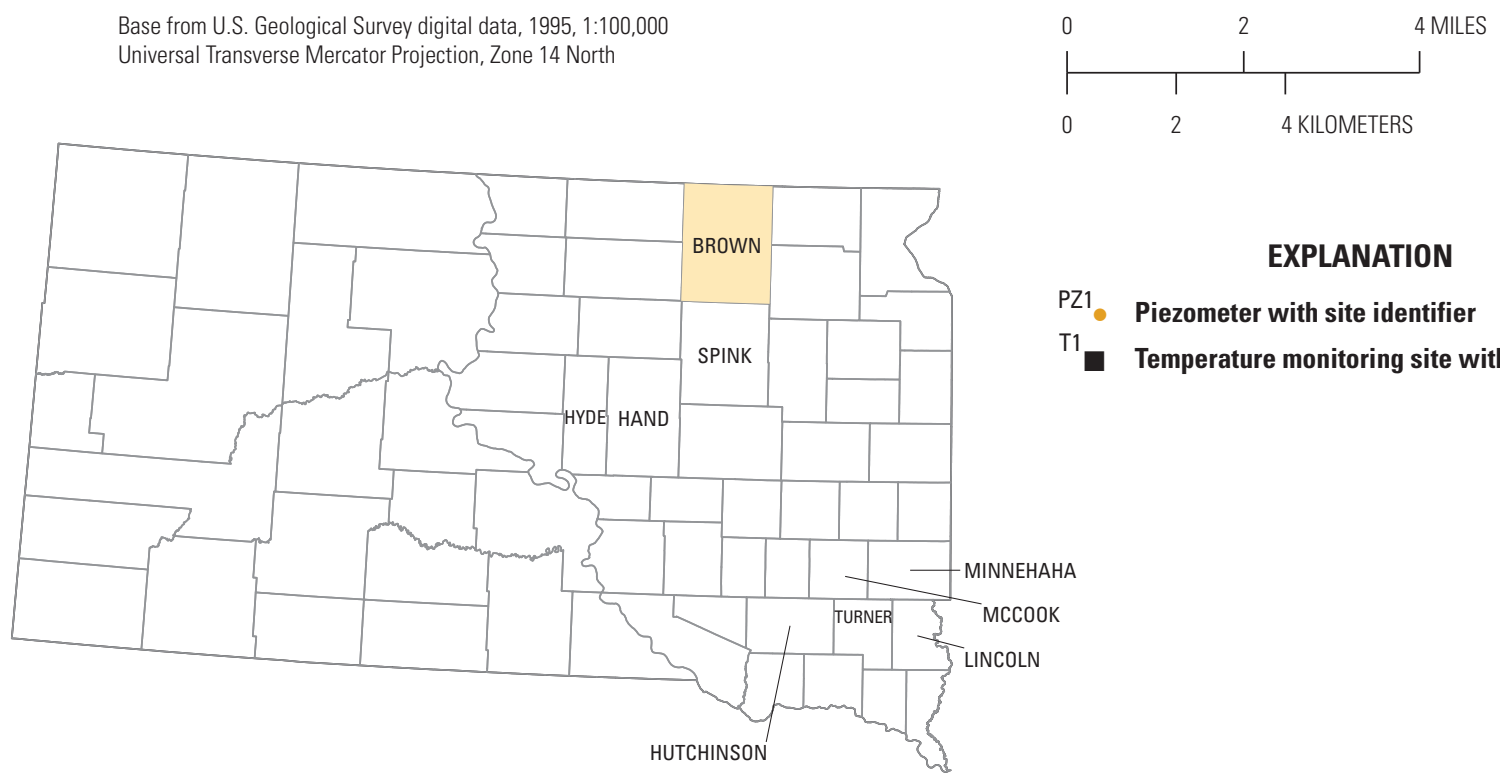

\section{EXPLANATION}

PZ1。 Piezometer with site identifier

${ }^{T 1}$ Temperature monitoring site with site identifier

Figure 23. Location of temperature monitoring sites and piezometers in model area. Location of counties in which vertical hydraulic conductivity studies have been conducted. 
Table 3. Vertical hydraulic conductivity of glacial till in eastern South Dakota.

\begin{tabular}{|c|c|c|c|c|c|}
\hline $\begin{array}{l}\text { Number } \\
\text { of wells }\end{array}$ & Till type & \multicolumn{2}{|c|}{$\begin{array}{l}\text { Vertical hydraulic conductivity, } \\
\text { in feet per day }\end{array}$} & Method & Original source \\
\hline \multicolumn{6}{|c|}{ Hyde, Hand, Spink, McCook, Hutchinson, Turner, and Lincoln Counties, South Dakota (fig. 23) } \\
\hline \multirow[t]{2}{*}{$\begin{array}{l}3 \text { screen-intake, } \\
27 \text { core-intake }\end{array}$} & Non-weathered & $\begin{array}{l}2.1 \times 10^{-5}-1.3 \times 10^{-4} \\
5.7 \times 10^{-5}\end{array}$ & $\begin{array}{l}\text { (range) } \\
\text { (mean) }\end{array}$ & $\begin{array}{l}\text { In situ permeability } \\
\text { tests analyzed by the } \\
\text { Hvorslev method }\end{array}$ & Cowman (1996) \\
\hline & Non-weathered & $\begin{array}{l}1.8 \times 10^{-5}-2.0 \times 10^{-4} \\
7.4 \times 10^{-5}\end{array}$ & $\begin{array}{l}\text { (range) } \\
\text { (mean) }\end{array}$ & $\begin{array}{l}\text { In situ permeability tests } \\
\text { analyzed by the Luthin } \\
\text { and Kirkham method }\end{array}$ & \\
\hline \multicolumn{6}{|c|}{ Hand and Hyde Counties, South Dakota (fig. 23) } \\
\hline 26 & Non-weathered & $2.1 \times 10^{-2}$ & $\begin{array}{l}\text { (median) } \\
\text { (median) }\end{array}$ & $\begin{array}{l}\text { In situ permeability } \\
\text { tests analyzed by the } \\
\text { Hvorslev method }\end{array}$ & $\begin{array}{l}\text { Cravens and Ruedisili } \\
\text { (1987) }\end{array}$ \\
\hline \multicolumn{6}{|c|}{ Minnehaha County, South Dakota (fig. 23) } \\
\hline \multirow[t]{2}{*}{$\begin{array}{l}14 \text { screen-intake, } \\
6 \text { core-intake }\end{array}$} & Transition zone & $\begin{array}{l}1.4 \times 10^{-4}-1.4 \times 10^{-1} \\
3.2 \times 10^{-3} \\
1.4 \times 10^{-5}-1.4 \times 10^{-2} \\
4.9 \times 10^{-4}\end{array}$ & $\begin{array}{l}\text { (range) } \\
\text { (mean) } \\
\text { (range) } \\
\text { (mean) }\end{array}$ & $\begin{array}{l}\text { In situ permeability } \\
\text { tests analyzed by the } \\
\text { Hvorslev and Bouwer- } \\
\text { Rice methods }\end{array}$ & $\begin{array}{l}\text { Davis and others } \\
\text { (1997) }\end{array}$ \\
\hline & Non-weathered & $\begin{array}{l}1.4 \times 10^{-5}-1.4 \times 10^{-4} \\
5.1 \times 10^{-5}\end{array}$ & $\begin{array}{l}\text { (range) } \\
\text { (mean) }\end{array}$ & & \\
\hline
\end{tabular}

\section{Evapotranspiration}

The potential evapotranspiration rate from the Elm aquifer also was estimated with the SWB analysis described in Supplement 6. In the SWB analysis used here, potential evapotranspiration was estimated using only temperature data; humidity and wind speed were not considered (Supplement 6). Potential evapotranspiration rates reflect the maximum rate that could be evapotranspired if the system is not waterlimited (for example, ponded water). Actual evapotranspiration is lower than potential evapotranspiration because the soil is usually water-limited during parts of the year. The annual potential evapotranspiration rate calculated by using the SWB analysis ranged from $21.8 \mathrm{in.}$ in WY 1983 to $27.0 \mathrm{in}$. in WY 1985, with an average of $24.6 \mathrm{in}$. The SWB analysis for this study used spatially uniform climate data because an averaged climate dataset was used for the model area.

Most evapotranspiration would happen where the overlying glacial till is absent or thin. To account for some upward movement of water in the glacial till where the hydraulic head was near the land surface, a multiplier array, developed from an equation used by Emmons (1990), was used to vary potential evapotranspiration spatially on the basis of glacial till thickness. Emmons (1990) decreased evapotranspiration linearly as till thickness, in feet, increased using equation 1 :

$$
\text { Evapotranspiration multiplier }=1-\frac{\text { till thickness }}{50}
$$

Where the till thickness was greater than $50 \mathrm{ft}$ in the model area, the cell in the multiplier array was set to zero. The modified average annual potential evapotranspiration during WY 1975-2009 was 11.0 in. over the model area. The distribution of modified average annual potential evaporation (fig. 25) shows the potential for larger evapotranspiration in the southeast part of the model area. The estimated minimum annual potential evapotranspiration of 9.8 in. averaged over the model area was in WY 1983, and the estimated maximum of $12.1 \mathrm{in.}$ was in WY 1985. 


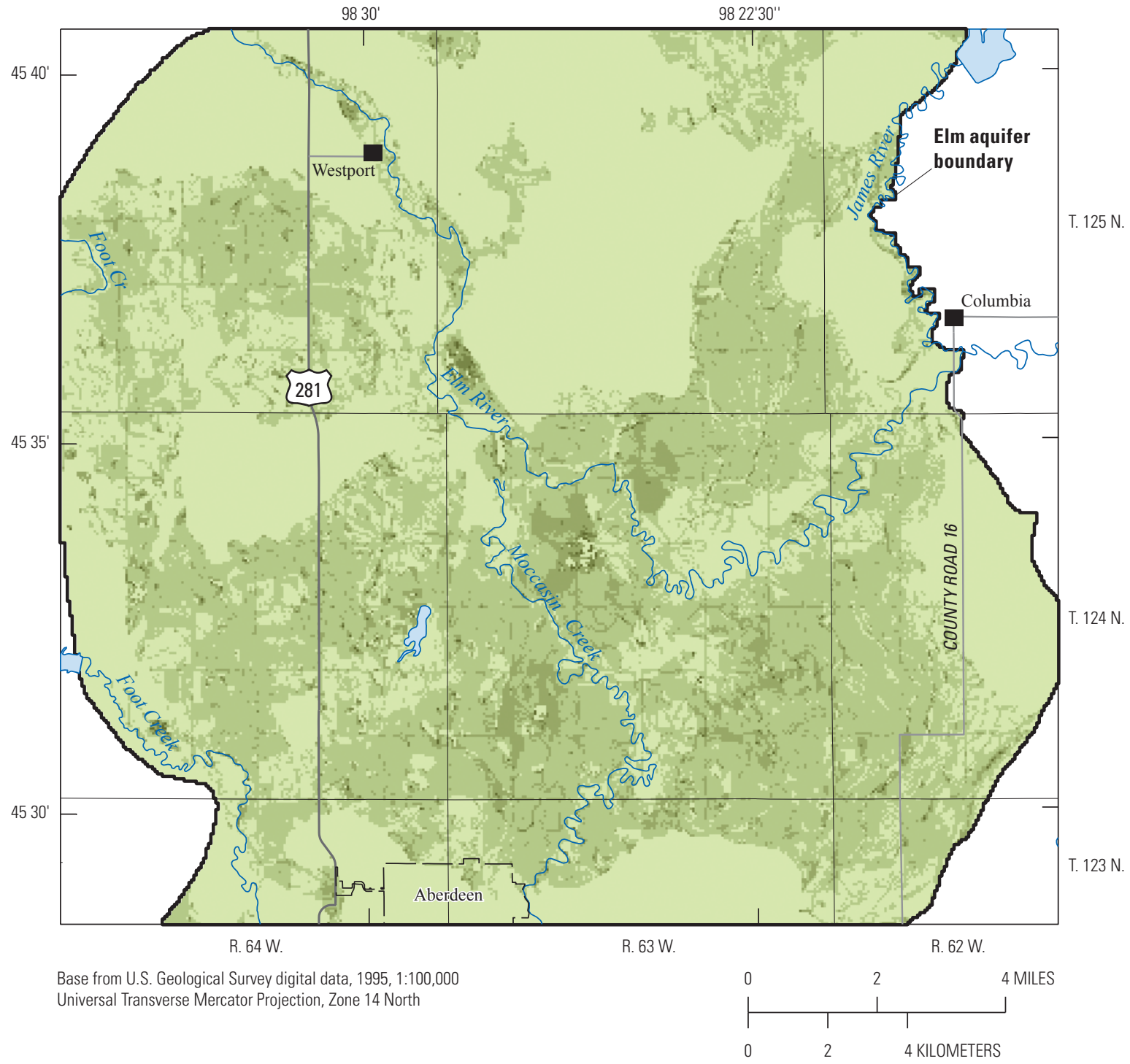

\section{EXPLANATION}

Mean recharge, in inches per year

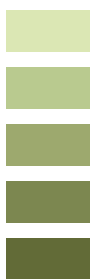

0 to less than 2

2 to less than 4

4 to less than 7

7 to less than 10

10 to less than 24

Figure 24. Spatial distribution of mean annual recharge to the Elm aquifer in water years 1975-2009, calculated with the soil-water-balance method, in model area. 


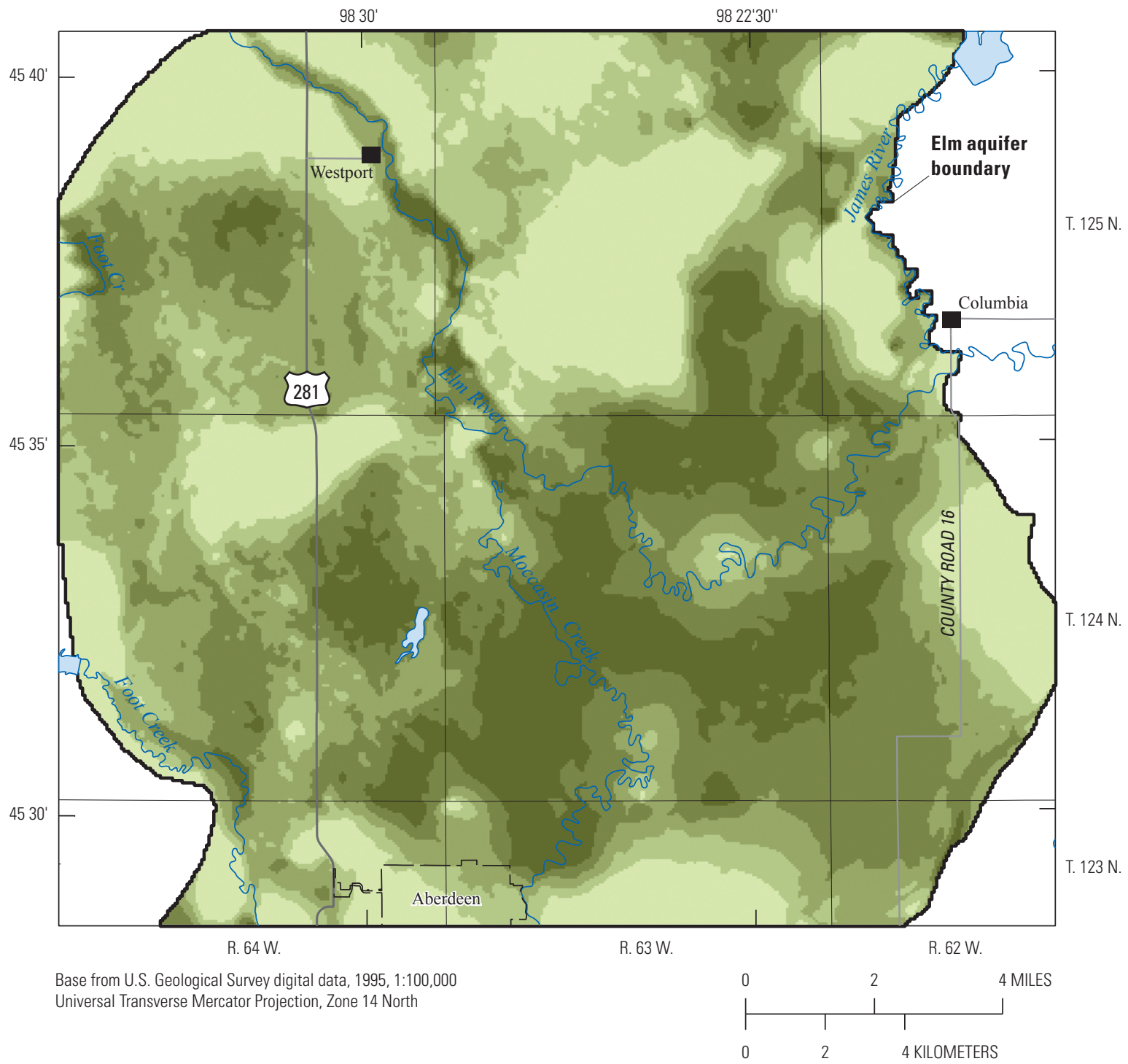

\section{EXPLANATION}

Potential evapotranspiration, in inches per year

0 to less than 5

5 to less than 10

10 to less than 15

15 to less than 20

20 to less than 25

Figure 25. Spatial distribution of average annual potential evapotranspiration in water years 19752009 in model area, calculated by using soil-water-balance derived potential evapotranspiration, which was modified with a till thickness multiplier array. 


\section{Interaction with Surface Water}

Interaction between the Elm aquifer and surface water exists primarily where the intervening glacial till is absent or thin. Foot Creek and the upper part of the Elm River are located in glacial meltwater channels incised into glacial recessional and ground moraine (fig. 5). The generalized average potentiometric surface (fig. 18) shows a hydraulic gradient toward these stream reaches, indicating that groundwater flows from the Elm aquifer to the stream. The range in vertical hydraulic conductivity at sites (fig. 23) along the Elm River (table 2) ranged from 0.1 to $2.5 \mathrm{ft} / \mathrm{d}$, and the thickness of the intervening sediments ranged from 6.1 to $17.8 \mathrm{ft}$.

Streamflow records for the USGS streamgage 06471500

(fig. 1) on the Elm River at Westport for the period 1946-2009 indicate that flow in Elm River is less than $3 \mathrm{ft}^{3} / \mathrm{s}$ about 30 percent of the time and less than $5 \mathrm{ft}^{3} / \mathrm{s}$ about 50 percent of the time (U.S. Geological Survey, 2011); therefore, fluctuations in streamflow gain from the Elm aquifer in this reach were estimated to be small, and streamflow gain from the Elm aquifer was assumed to be less than about $5 \mathrm{ft}^{3} / \mathrm{s}$.

The reach of the Elm River between the streamgage 06471500 and the seasonal water-stage gage on the Elm River near Ordway (streamgage 06471510) includes a small dam (Ordway Dam) and reservoir, which limit quantification of streamflow gain or loss; however, comparison of selected field measurements of streamflow at streamgage 06471510 (Rantz and others, 1982) and mean daily streamflow at streamgage 06471500 indicates a small streamflow loss to the aquifer (table 4). Two field measurements when flow was relatively steady indicate that the Elm River was losing streamflow to the Elm aquifer of about 1 to $5 \mathrm{ft}^{3} / \mathrm{s}$.

Interaction between the Elm River and the Elm aquifer was examined by comparison of Elm aquifer water levels and stage in the Elm River. Observation wells A-1 (table 5) and A-2 (table 6) completed in the Elm aquifer and the USGS stage-only streamgage 453430098263200 on the Elm River (fig. 22) were monitored with continuous recording equipment during 2008-09. Well A-1 is located about $100 \mathrm{ft}$ east of the streamgage, and well A-2 is about $1,000 \mathrm{ft}$ west of the streamgage. Comparison of hydraulic head in the Elm aquifer, stream stage in the Elm River, and daily precipitation shows the response of the Elm aquifer to precipitation (fig. 26). The daily precipitation is for precipitation station 399138 (fig. 1), located about 7 mi upstream on the Elm River. The rise in hydraulic head exists for a few days following a precipitation event. During flooding in the spring of 2009, recording equipment for well A-1 and the streamgage were inoperable. When the stream receded, the hydraulic head in well A-2 tracked closely with the decrease in stage. The altitude of the Elm River stage generally ranges between 1,306 and 1,307 ft except during flooding conditions. The altitude of the bottom of the Elm River at the streamgage was about $1,302 \mathrm{ft}$, indicating that the river bottom was at about the same altitude as the top of the Elm aquifer near the Elm River streamgage. The resistivity profile for survey 9 (fig. S2-10, Supplement 2), which is located adjacent to the Elm River upstream from well A-1, indicated a glacial till thickness of about 15-20 ft. Variability in till thickness near the Elm River could result in substantial heterogeneity in the hydraulic connection of the stream and the Elm aquifer.

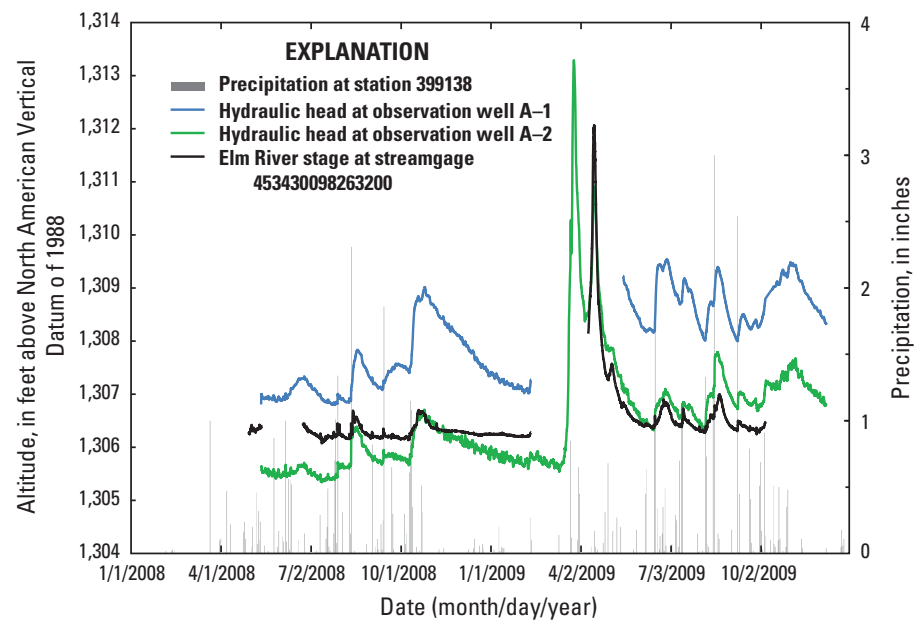

Figure 26. Comparison of precipitation, hydraulic head in Elm aquifer for wells $\mathrm{A}-1$ and $\mathrm{A}-2$, and stage in Elm River.

In general, the Elm River and Moccasin Creek were assumed to interact with the Elm aquifer as they cross the Lake Dakota Plain because the top of the Elm aquifer was at or near the land surface. A summary of the seasonal mean daily streamflow at USGS streamgage 06471770 (table 7) shows mean seasonal streamflow that ranged between 1.7 and $3.8 \mathrm{ft}^{3} / \mathrm{s}$.

Table 4. Comparison of selected streamflow measurements at U.S. Geological Survey streamgage 06471510 with mean daily streamflow at U.S. Geological Survey streamgage 06471500.

$\left[\mathrm{ft}^{3} / \mathrm{s}\right.$, cubic feet per second]

\begin{tabular}{|c|c|c|c|c|c|c|}
\hline \multicolumn{2}{|c|}{ Field measurement at station 06471510} & \multicolumn{5}{|c|}{ Mean daily streamflow at station 06471500 , in $\mathrm{ft}^{3} / \mathrm{s}$} \\
\hline Date and time & $\begin{array}{l}\text { Streamflow, } \\
\text { in } \mathrm{ft}^{3} / \mathrm{s}\end{array}$ & $\begin{array}{l}\text { Day prior to } \\
\text { measurement }\end{array}$ & $\begin{array}{c}\text { Day of } \\
\text { measurement }\end{array}$ & $\begin{array}{c}\text { Day } 1 \text { after } \\
\text { measurement }\end{array}$ & $\begin{array}{c}\text { Day } 2 \text { after } \\
\text { measurement }\end{array}$ & $\begin{array}{c}\text { Day } 3 \text { after } \\
\text { measurement }\end{array}$ \\
\hline $8 / 9 / 200510: 35$ & 42.3 & 45 & 42 & 38 & 37 & 36 \\
\hline $4 / 27 / 200011: 30$ & 77.3 & 84 & 82 & 83 & 87 & 89 \\
\hline
\end{tabular}


Table 5. Lithologic log for well A-1.

[Datum is North American Vertical Datum of 1988; screened interval is from 41 to 51 feet; U.S. Geological Survey station number 453430098262901]

\begin{tabular}{|c|c|c|}
\hline $\begin{array}{l}\text { Altitude } \\
\text { (feet) }\end{array}$ & $\begin{array}{l}\text { Depth below } \\
\text { land surface } \\
\text { (feet) }\end{array}$ & Description \\
\hline $1,312.8-1,309.8$ & $0-3$ & Topsoil, black \\
\hline $1,309.8-1,302.8$ & $3-10$ & Clay, dark-gray \\
\hline $1,302.8-1,297.8$ & $10-15$ & Sand, brown, olive, coarse \\
\hline $1,297.8-1,295.8$ & $15-17$ & Sand and gravel, gray \\
\hline $1,295.8-1,294.8$ & $17-18$ & Clay, gray \\
\hline $1,294.8-1,256.8$ & $18-56$ & $\begin{array}{l}\text { Sand, gray, medium to coarse, } \\
\text { subangular to subrounded; some } \\
\text { layers of clay and coal }\end{array}$ \\
\hline $1,256.8-1,250.8$ & $56-62$ & Clay, gray \\
\hline
\end{tabular}

Table 6. Lithologic log for well A-2.

[Datum is North American Vertical Datum of 1988; screened interval is from 31.5 to 41.5 feet; U.S. Geological Survey station number 453430098264501 ]

\begin{tabular}{ccl}
\hline $\begin{array}{c}\text { Altitude } \\
\text { (feet) }\end{array}$ & $\begin{array}{c}\text { Depth below } \\
\text { land surface } \\
\text { (feet) }\end{array}$ & \multicolumn{1}{c}{ Description } \\
\hline $1,312.8-1,309.8$ & $0-3$ & Topsoil, black \\
$1,309.8-1,303.8$ & $3-9$ & Clay, dark-gray to gray \\
$1,303.8-1,300.8$ & $9-12$ & Clay light-gray to gray \\
$1,300.8-1,298.8$ & $12-14$ & Sand, gray \\
$1,298.8-1,295.8$ & $14-17$ & Clay, yellowish brown \\
$1,295.8-1,287.8$ & $17-25$ & $\begin{array}{l}\text { Clay, yellowish brown, some sand } \\
\text { and gravel }\end{array}$ \\
$1,287.8-1,283.8$ & $25-29$ & Clay, gray, sandy \\
$1,283.8-1,275.8$ & $29-37$ & Sand, gray \\
$1,275.8-1,270.8$ & $37-42$ & Sand, gray, some clay \\
$1,270.8-1,266.8$ & $42-46$ & Sand \\
$1,266.8-1,260.8$ & $46-52$ & Clay, gray, sandy \\
\hline
\end{tabular}

\section{Water Use}

Water use from the glacial aquifer system mostly was from the Elm aquifer and included irrigation, municipal, and suburban water supplies. All of the production wells (fig. 27) were completed in the Elm aquifer, with the exception of a low-production well east of Columbia that was completed in the Middle James aquifer. Estimates of water use were determined on the basis of water rights permits from the South Dakota Department of Environment and Natural Resources Water Rights Program (SDDENR-WR) and pumping records when available. For the years when pumping records were not available, withdrawals were estimated on the basis of the well permit, correlations with existing pumping records, and examination of changes in well hydrographs. Some irrigation permits were for multiple well arrangements where the water was pumped to a central holding pond and then pumped to the irrigation system. Water use was distributed equally between these wells. The distribution of production wells (fig. 27) includes the general locations for multi-well irrigation systems.

Table 7. Summary of seasonal mean daily streamflow at U.S. Geological Survey streamgage 06471770.

\begin{tabular}{ccccc}
\hline \multicolumn{2}{c}{ Period of record } & \multicolumn{3}{c}{$\begin{array}{c}\text { Mean daily streamflow, in cubic feet } \\
\text { per second }\end{array}$} \\
\hline \multicolumn{1}{c}{ Begin } & End & $\begin{array}{c}\text { Seasonal } \\
\text { maximum }\end{array}$ & $\begin{array}{c}\text { Seasonal } \\
\text { minimum }\end{array}$ & $\begin{array}{c}\text { Seasonal } \\
\text { mean }\end{array}$ \\
\hline $3 / 1 / 2000$ & $9 / 30 / 2000$ & 3.6 & 1.6 & 2.0 \\
$3 / 14 / 2001$ & $9 / 4 / 2001$ & 4.8 & 1.6 & 2.5 \\
$3 / 22 / 2003$ & $9 / 30 / 2003$ & 3.1 & 1.4 & 2.2 \\
$3 / 5 / 2004$ & $9 / 30 / 2004$ & 2.9 & 1.5 & 1.9 \\
$3 / 6 / 2005$ & $9 / 30 / 2005$ & 2.7 & 1.5 & 1.8 \\
$3 / 26 / 2006$ & $7 / 14 / 2006$ & 2.4 & 1.3 & 1.7 \\
$3 / 11 / 2007$ & $9 / 30 / 2007$ & 7.8 & 1.6 & 2.9 \\
$3 / 23 / 2008$ & $9 / 30 / 2008$ & 3.3 & 1.3 & 1.7 \\
$3 / 19 / 2009$ & $9 / 30 / 2009$ & 6.3 & 1.8 & 3.1 \\
$3 / 1 / 2010$ & $9 / 30 / 2010$ & 7.1 & 1.7 & 3.6 \\
$3 / 16 / 2011$ & $8 / 2 / 2011$ & 7.2 & 2.0 & 3.8 \\
\hline
\end{tabular}

The estimated water-use rate by water year ranged from 1.0 to $2.4 \mathrm{ft}^{3} / \mathrm{s}$ (table 8). The irrigation rate was greatest from WY 1980-89, followed by a decrease with the cancellation of an irrigation permit. The increase in water use after WY 2005 was the result of increased municipal production.

\section{Numerical Model of Groundwater Flow}

The numerical model included three aquifer layers separated by confining layers. Layer 1 represented the Elm aquifer and saturated sandy units in the Lake Dakota Plain (grouped as Elm aquifer), layer 2 represented the Middle James aquifer, and layer 3 represented the Deep James aquifer, as described in the "Hydrogeologic Framework" section. The USGS finite-difference groundwater model, MODFLOW2005 (Harbaugh, 2005), was used to simulate groundwater flow in the glacial aquifer system. The Parameter ESTimation code (PEST) (Doherty, 2010) was used to calibrate the model. PEST is an open-source, public-domain software suite that allows model-independent parameter estimation. The software is accompanied by supplementary open-source and public-domain software suites for calibration of groundwater models (Doherty, 2008). This software, together with extensive documentation, can be downloaded from $h t t p: / / w w w$. pesthomepage.org/. 


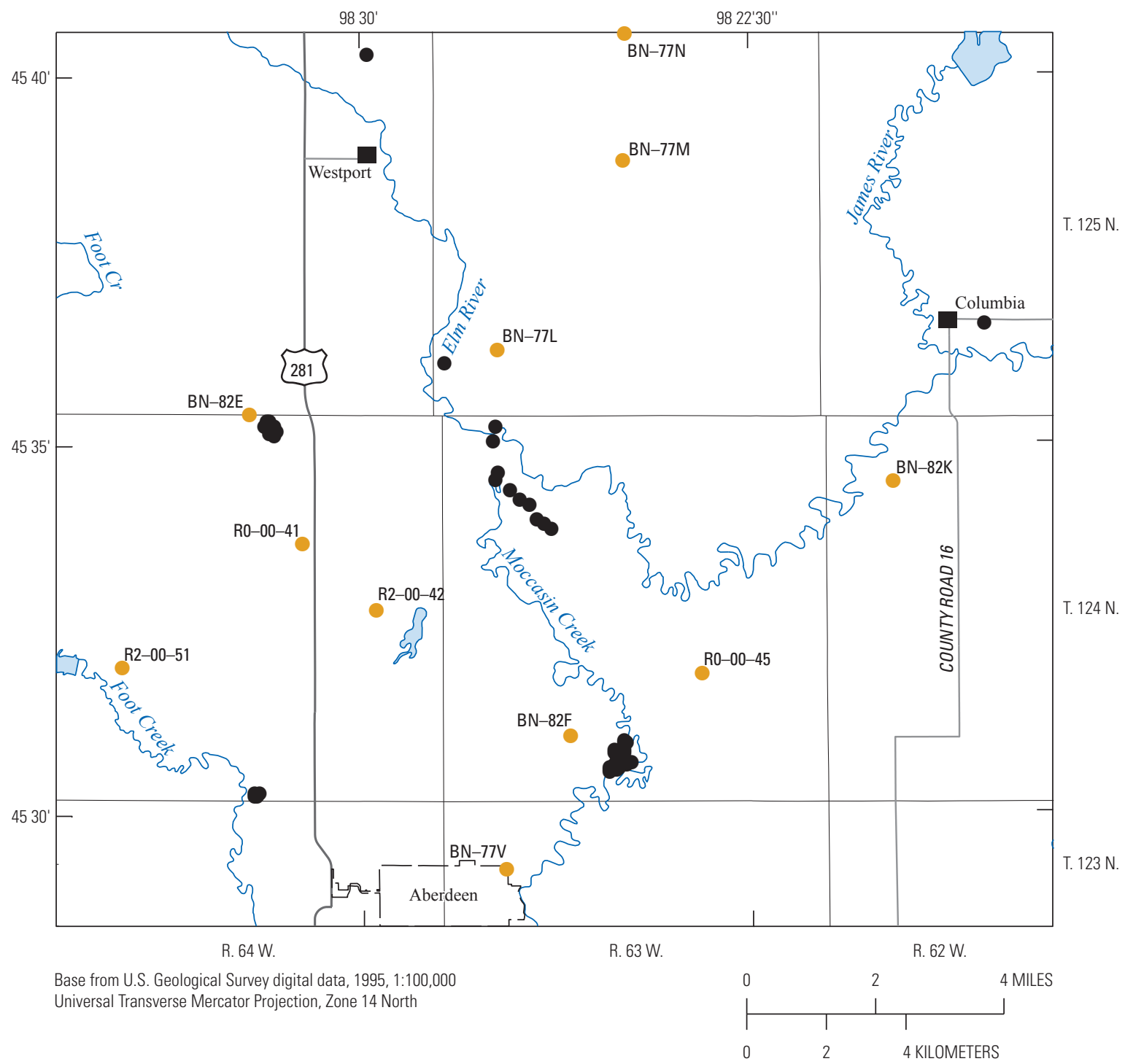

EXPLANATION

\section{$\begin{array}{cl}\bullet & \text { Production well } \\ \mathrm{BN}-77 \mathrm{~V} & \text { Observation well and identifier }\end{array}$}

Figure 27. Location of production wells and South Dakota Department of Environment and Natural Resources observation wells in model area. 
Table 8. Estimated water-use rates, for water years 1975-2009.

\begin{tabular}{|c|c|}
\hline $\begin{array}{l}\text { Water } \\
\text { year }\end{array}$ & $\begin{array}{c}\text { Water-use rate, } \\
\text { in cubic feet per second }\end{array}$ \\
\hline 1975 & 1.0 \\
\hline 1976 & 1.4 \\
\hline 1977 & 1.0 \\
\hline 1978 & 1.0 \\
\hline 1979 & 1.1 \\
\hline 1980 & 1.5 \\
\hline 1981 & 1.9 \\
\hline 1982 & 2.1 \\
\hline 1983 & 2.0 \\
\hline 1984 & 2.0 \\
\hline 1985 & 2.0 \\
\hline 1986 & 1.7 \\
\hline 1987 & 1.8 \\
\hline 1988 & 1.9 \\
\hline 1989 & 1.7 \\
\hline 1990 & 1.6 \\
\hline 1991 & 1.6 \\
\hline 1992 & 1.5 \\
\hline 1993 & 1.1 \\
\hline 1994 & 1.6 \\
\hline 1995 & 1.8 \\
\hline 1996 & 1.8 \\
\hline 1997 & 1.3 \\
\hline 1998 & 1.8 \\
\hline 1999 & 1.8 \\
\hline 2000 & 1.3 \\
\hline 2001 & 1.6 \\
\hline 2002 & 1.5 \\
\hline 2003 & 1.5 \\
\hline 2004 & 1.5 \\
\hline 2005 & 1.1 \\
\hline 2006 & 1.8 \\
\hline 2007 & 2.0 \\
\hline 2008 & 2.1 \\
\hline 2009 & 2.4 \\
\hline
\end{tabular}

\section{Calibration Stress Periods}

Groundwater flow was simulated with 75 variable-length stress periods for 35 years, beginning on October 1, 1974, and ending September 30, 2009 (WY 1975-2009; table 9), to calibrate the model. The first stress period simulated average input parameters for the 35 -year period as a means to provide initial conditions representative of the long-term climate. Subsequent stress periods included four stress periods for WY 1980-82 and WY 2000-2009: October-February, March-April, May-June, and July-September; all other water years were simulated using one stress period. Water years 1980-82 represented a dry period at the end of a 30-year trend of below average precipitation (fig. 2). Water years 2000-2009 included a dry and wet period following the wet period in the 1990s. These stress periods were selected for seasonal calibration of wet and dry conditions. The other periods were simulated with yearly stress periods to reduce model run times.

\section{Finite-Difference Grid and Boundary Conditions}

The finite-difference grid consisted of 368 rows and 410 columns with a cell size of $200 \mathrm{ft}$ on a side. Model boundaries were represented by specified-head boundaries and no-flow boundaries (figs. 28-30). The northern and southern boundaries of model layers 1 and 2 were represented by timevariant specified-head boundaries (figs. 31-32). Layer 3 was assigned time-variant specified-head boundaries where aquifer boundaries crossed the edges of the grid, namely on the northern, eastern, and southern boundaries (fig. 33).

The land surface, stream altitudes, regional hydraulic heads based on the potentiometric surface prepared from water levels collected at wells that had long-term records (fig. 18; table S7-1), and observed hydraulic heads near the boundaries (fig. 18) were used to estimate the hydraulic head distribution at the boundaries for each stress period for model layer 1. The minimum, mean, and maximum values for all stress periods for model layer 1 are shown in figure 31 .

Hydraulic heads near the boundaries (fig. 34) and a numerically simulated potentiometric surface from Emmons (1990) (fig. 20) were used to estimate the hydraulic head distribution at the boundaries for each stress period for model layer 2 . The minimum, mean, and maximum values for all stress periods for model layer 2 are shown in figure 32 .

Hydraulic heads near the boundaries (fig. 35) and the numerically simulated potentiometric surface from Emmons (1990) (fig. 21) were used to estimate the hydraulic head distribution at the boundaries for each stress period for model layer 3 . The minimum, mean, and maximum values for all stress periods for model layer 3 are shown in figure 33 .

The estimated potentiometric surface describing groundwater flow (fig. 18) was used to estimate the starting hydraulic heads for model layer 1 . The starting hydraulic heads for model layers 2 and 3 were estimated on the basis of mean hydraulic head values (figs. 34 and 35, respectively) and the simulated potentiometric surfaces from Emmons (1990) (figs. 20-21). Water-level data for wells completed in the Elm, Middle James, and Deep James aquifers can be accessed at http://nwis.waterdata.usgs.gov/sd/nwis/gwlevels. 
Table 9. Simulated stress periods, water years 1975-2009.

\begin{tabular}{|c|c|c|c|}
\hline $\begin{array}{l}\text { Stress period } \\
\text { (SP) }\end{array}$ & $\begin{array}{l}\text { Beginning } \\
\text { date }\end{array}$ & Ending date & $\begin{array}{l}\text { Stress length } \\
\text { (months) }\end{array}$ \\
\hline SP1 & $10 / 01 / 1974$ & 09/30/2009 & 420 \\
\hline SP2 & $10 / 01 / 1974$ & 09/30/1975 & 12 \\
\hline SP3 & $10 / 01 / 1975$ & 09/30/1976 & 12 \\
\hline SP4 & $10 / 01 / 1976$ & 09/30/1977 & 12 \\
\hline SP5 & 10/01/1977 & 09/30/1978 & 12 \\
\hline SP6 & $10 / 01 / 1978$ & 09/30/1979 & 12 \\
\hline SP7 & $10 / 01 / 1979$ & 02/29/1980 & 5 \\
\hline SP8 & 03/01/1980 & 04/30/1980 & 2 \\
\hline SP9 & 05/01/1980 & 06/30/1980 & 2 \\
\hline SP10 & 07/01/1980 & 09/30/1980 & 3 \\
\hline SP11 & $10 / 01 / 1980$ & $02 / 28 / 1981$ & 5 \\
\hline SP12 & 03/01/1981 & 04/30/1981 & 2 \\
\hline SP13 & 05/01/1981 & 06/30/1981 & 2 \\
\hline SP14 & 07/01/1981 & 09/30/1981 & 3 \\
\hline SP15 & $10 / 01 / 1981$ & $02 / 28 / 1982$ & 5 \\
\hline SP16 & 03/01/1982 & 04/30/1982 & 2 \\
\hline SP17 & 05/01/1982 & 06/30/1982 & 2 \\
\hline SP18 & 07/01/1982 & 09/30/1982 & 3 \\
\hline SP19 & $10 / 01 / 1982$ & 09/30/1983 & 12 \\
\hline SP20 & $10 / 01 / 1983$ & 09/30/1984 & 12 \\
\hline SP21 & $10 / 01 / 1984$ & 09/30/1985 & 12 \\
\hline SP22 & $10 / 01 / 1985$ & 09/30/1986 & 12 \\
\hline SP23 & $10 / 01 / 1986$ & 09/30/1987 & 12 \\
\hline $\mathrm{SP} 24$ & $10 / 01 / 1987$ & 09/30/1988 & 12 \\
\hline $\mathrm{SP} 25$ & $10 / 01 / 1988$ & 09/30/1989 & 12 \\
\hline SP26 & $10 / 01 / 1989$ & 09/30/1990 & 12 \\
\hline SP27 & 10/01/1990 & 09/30/1991 & 12 \\
\hline SP28 & $10 / 01 / 1991$ & 09/30/1992 & 12 \\
\hline SP29 & 10/01/1992 & 09/30/1993 & 12 \\
\hline SP30 & $10 / 01 / 1993$ & 09/30/1994 & 12 \\
\hline SP31 & 10/01/1994 & 09/30/1995 & 12 \\
\hline SP32 & $10 / 01 / 1995$ & 09/30/1996 & 12 \\
\hline SP33 & 10/01/1996 & 09/30/1997 & 12 \\
\hline SP34 & $10 / 01 / 1997$ & 09/30/1998 & 12 \\
\hline SP35 & $10 / 01 / 1998$ & 09/30/1999 & 12 \\
\hline SP36 & 10/01/1999 & $02 / 29 / 2000$ & 5 \\
\hline SP37 & 03/01/2000 & $04 / 30 / 2000$ & 2 \\
\hline SP38 & $05 / 01 / 2000$ & $06 / 30 / 2000$ & 2 \\
\hline SP39 & $07 / 01 / 2000$ & 09/30/2000 & 3 \\
\hline SP40 & $10 / 01 / 2000$ & $02 / 28 / 2001$ & 5 \\
\hline SP41 & 03/01/2001 & $04 / 30 / 2001$ & 2 \\
\hline SP42 & 05/01/2001 & $06 / 30 / 2001$ & 2 \\
\hline SP43 & $07 / 01 / 2001$ & 09/30/2001 & 3 \\
\hline SP44 & $10 / 01 / 2001$ & $02 / 28 / 2002$ & 5 \\
\hline
\end{tabular}

Table 9. Simulated stress periods, water years 1975-2009.Continued

\begin{tabular}{cccc}
\hline $\begin{array}{c}\text { Stress period } \\
\text { (SP) }\end{array}$ & $\begin{array}{c}\text { Beginning } \\
\text { date }\end{array}$ & Ending date & $\begin{array}{c}\text { Stress length } \\
\text { (months) }\end{array}$ \\
\hline SP45 & $03 / 01 / 2002$ & $04 / 30 / 2002$ & 2 \\
SP46 & $05 / 01 / 2002$ & $06 / 30 / 2002$ & 2 \\
SP47 & $07 / 01 / 2002$ & $09 / 30 / 2002$ & 3 \\
SP48 & $10 / 01 / 2002$ & $02 / 28 / 2003$ & 5 \\
SP49 & $03 / 01 / 2003$ & $04 / 30 / 2003$ & 2 \\
SP50 & $05 / 01 / 2003$ & $06 / 30 / 2003$ & 2 \\
SP51 & $07 / 01 / 2003$ & $09 / 30 / 2003$ & 3 \\
SP52 & $10 / 01 / 2003$ & $02 / 29 / 2004$ & 5 \\
SP53 & $03 / 01 / 2004$ & $04 / 30 / 2004$ & 2 \\
SP54 & $05 / 01 / 2004$ & $06 / 30 / 2004$ & 2 \\
SP55 & $07 / 01 / 2004$ & $09 / 30 / 2004$ & 3 \\
SP56 & $10 / 01 / 2004$ & $02 / 28 / 2005$ & 5 \\
SP57 & $03 / 01 / 2005$ & $04 / 30 / 2005$ & 2 \\
SP58 & $05 / 01 / 2005$ & $06 / 30 / 2005$ & 2 \\
SP59 & $07 / 01 / 2005$ & $09 / 30 / 2005$ & 3 \\
SP60 & $10 / 01 / 2005$ & $02 / 28 / 2006$ & 5 \\
SP61 & $03 / 01 / 2006$ & $04 / 30 / 2006$ & 2 \\
SP62 & $05 / 01 / 2006$ & $06 / 30 / 2006$ & 2 \\
SP63 & $07 / 01 / 2006$ & $09 / 30 / 2006$ & 3 \\
SP64 & $10 / 01 / 2006$ & $02 / 28 / 2007$ & 5 \\
SP65 & $03 / 01 / 2007$ & $04 / 30 / 2007$ & 2 \\
SP66 & $05 / 01 / 2007$ & $06 / 30 / 2007$ & 2 \\
SP67 & $07 / 01 / 2007$ & $09 / 30 / 2007$ & 3 \\
SP68 & $10 / 01 / 2007$ & $02 / 29 / 2008$ & 5 \\
SP69 & $03 / 01 / 2008$ & $04 / 30 / 2008$ & 2 \\
SP70 & $05 / 01 / 2008$ & $06 / 30 / 2008$ & 2 \\
SP71 & $07 / 01 / 2008$ & $09 / 30 / 2008$ & 3 \\
SP72 & $10 / 01 / 2008$ & $02 / 28 / 2009$ & 5 \\
SP73 & $03 / 01 / 2009$ & $04 / 30 / 2009$ & 2 \\
SP74 & $05 / 01 / 2009$ & $06 / 30 / 2009$ & 2 \\
SP75 & $07 / 01 / 2009$ & $09 / 30 / 2009$ & 3 \\
\hline & & & \\
\hline
\end{tabular}

\section{Representation of Hydraulic Properties}

Hydraulic properties of the glacial aquifer system were represented by parameters with values optimized by using parameter estimation through the PEST computer code.

Parameter estimation relates observed measurements, such as hydraulic head, to model input parameters that represent physical properties of the simulated groundwater system. Solution of the parameter estimation problem involves mathematically determining the best modeled fit to the observed data by varying the input parameters. An approach and guidelines for application of parameter estimation to the calibration groundwater models are described by Hill (1998). The guidelines to using PEST for groundwater-model calibration by 


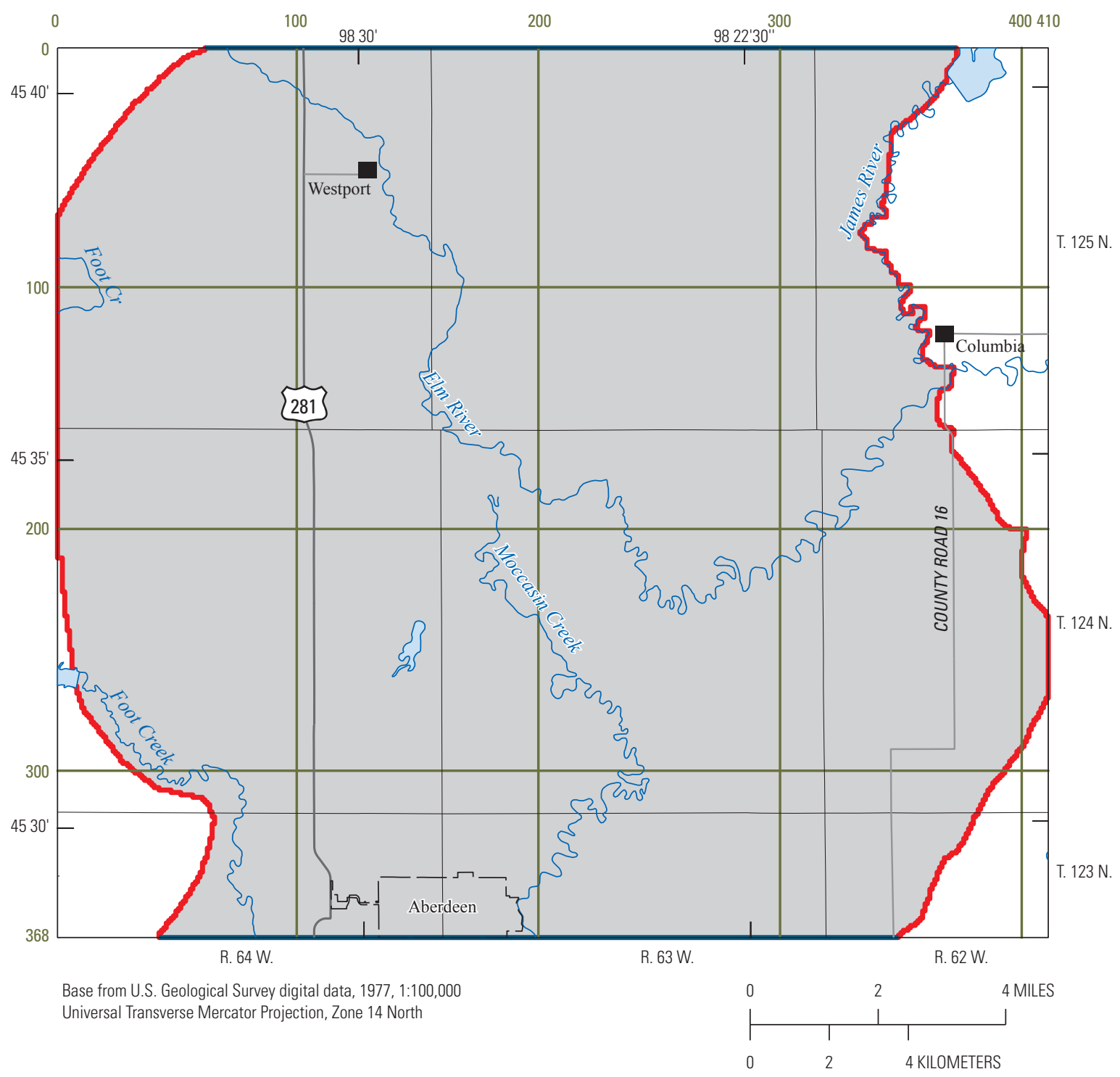

EXPLANATION

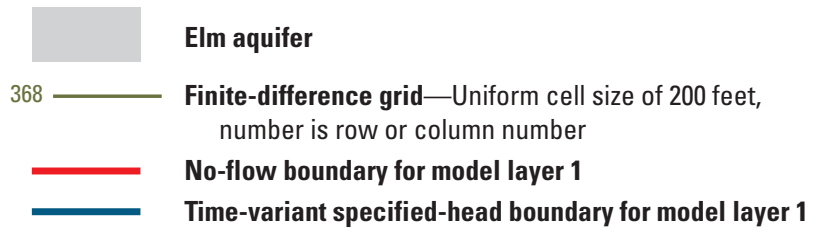

Figure 28. Boundary conditions for model layer 1. 


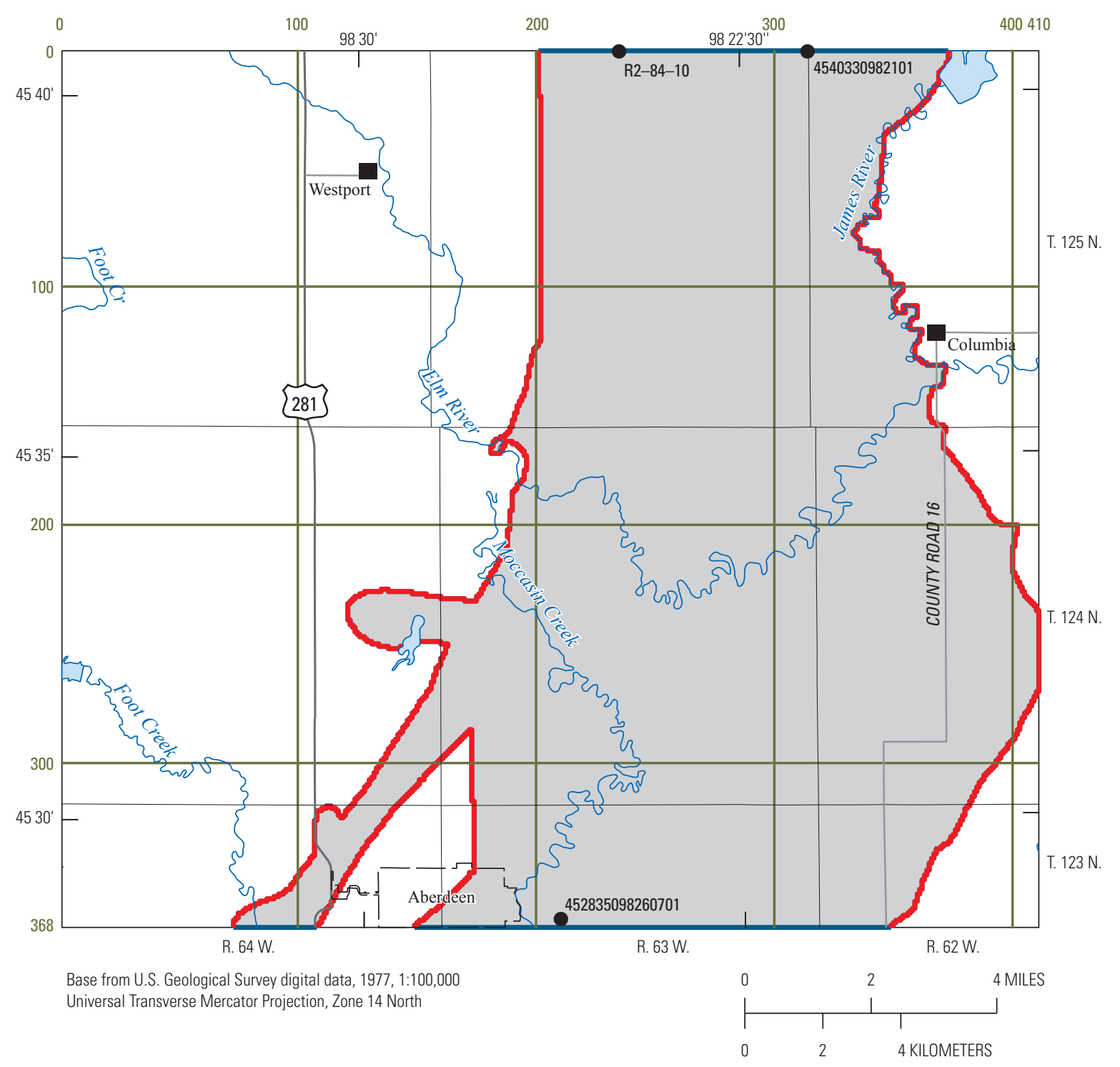

EXPLANATION

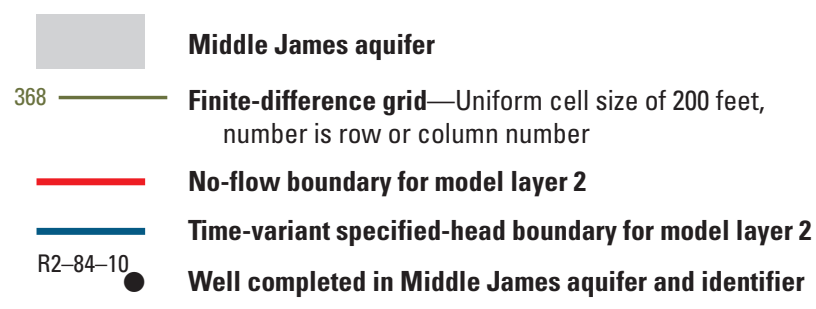

Figure 29. Boundary conditions for model layer 2. 


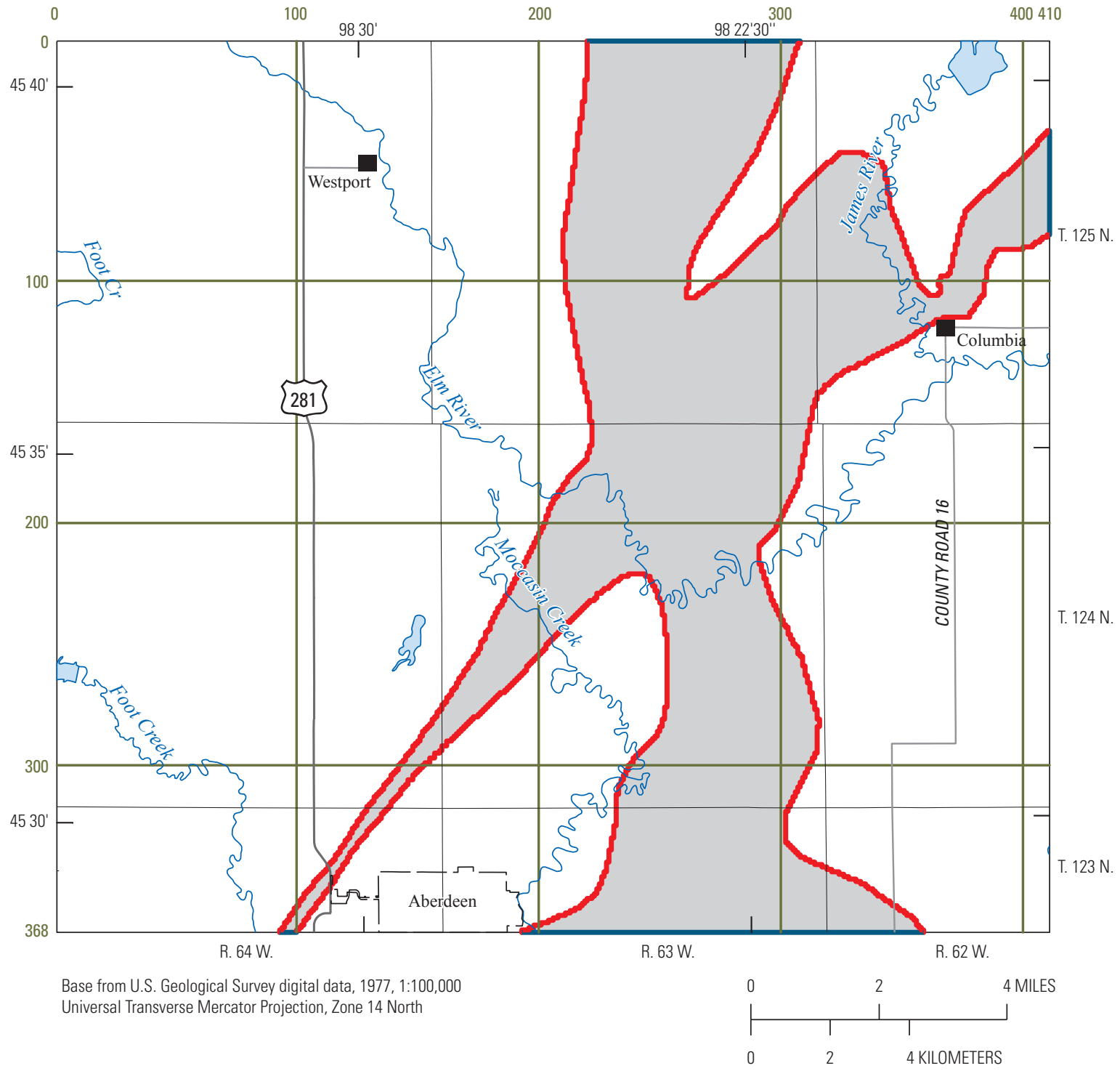

EXPLANATION

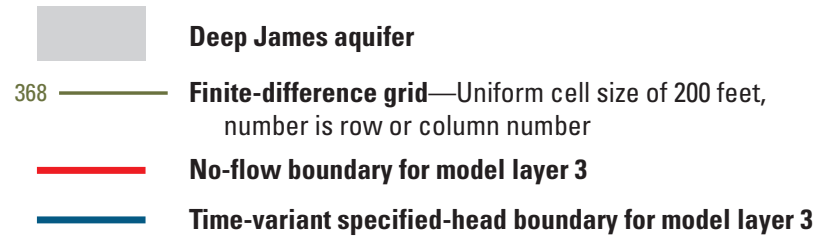

Figure 30. Boundary conditions for model layer 3. 

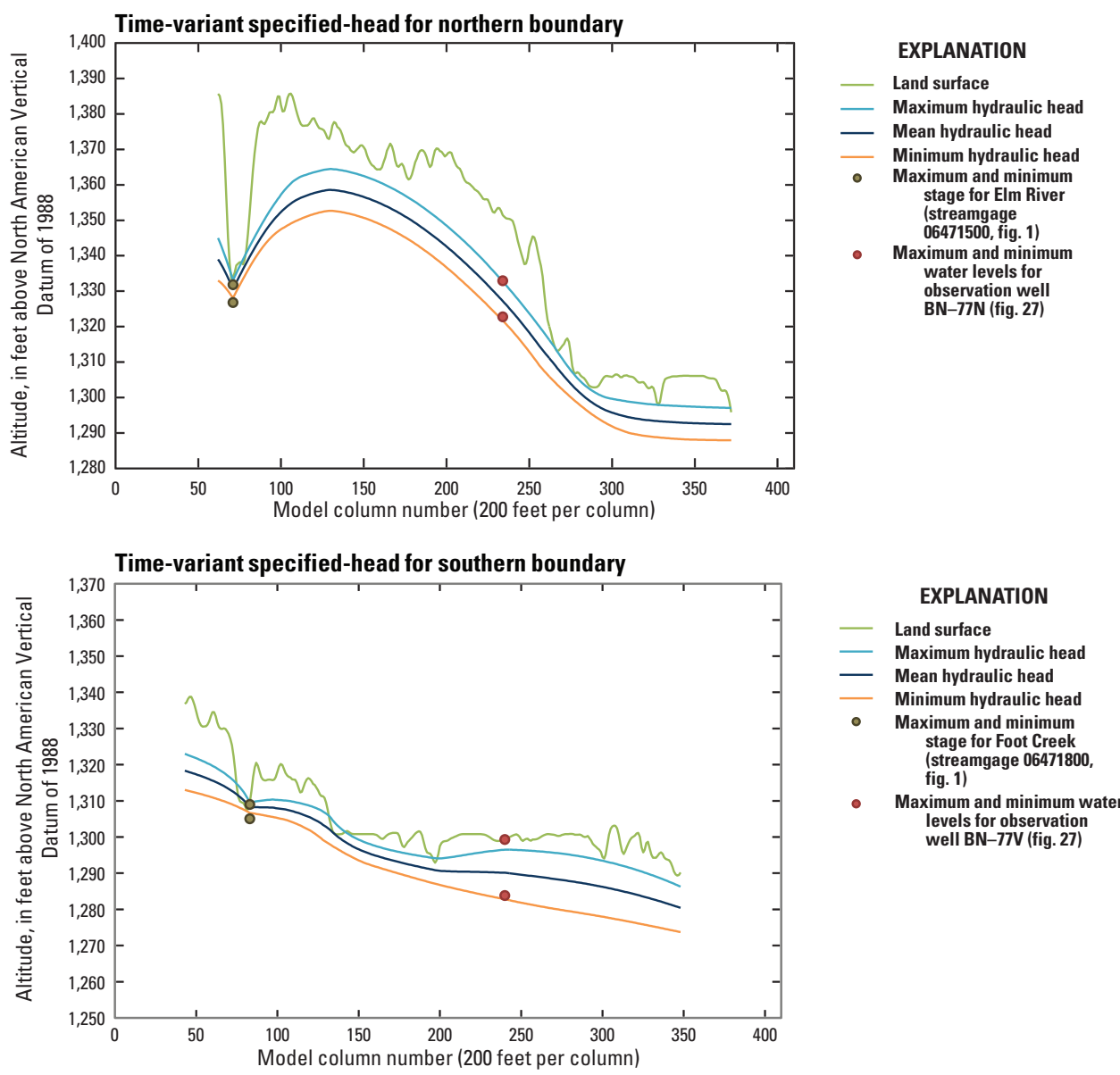

Figure 31. Range in time-variant specified-head boundaries assigned for model layer 1 for all stress periods.

Doherty and Hunt (2010) were used to develop the parameter estimation approach used in this study.

Commonly, a given number of parameters are used to represent zones of uniform hydraulic conductivity to minimize the number of parameters estimated with parameter estimation. A more flexible approach to model parameterization was used for representing horizontal hydraulic conductivity in model layer 1 because of the substantial number of observations (hydraulic head values) that could be used to constrain the parameter estimation.

Hydraulic conductivity for model layer 1 was simulated using pilot points (Doherty and others, 2010) and traditional piecewise-constant parameter zones. The hydraulic conductivity parameterization was grouped into nine zonations (fig. 36; table 10) delineated on the basis of the geology and landforms (fig. 5). This grouping of hydraulic conductivity is described here; the overall approach to the pilot-point parameterization is described below. Pilot points in zone HK1_1 represent sediments deposited by the Elm River entering ancient Lake Dakota, with more gravel having been deposited toward the west (Leap, 1986). Pilot points in zone HK1_7 represented the deltaic deposits from the Elm River meltwater channel that became finer to the east. Pilot points in zone
HK1_2 represented areas with buried channel deposits of sand and gravel in cut and fill sequences with highly variable hydraulic connection in recessional and ground moraine. Pilot points in Zone HK1_3 represented the area overlain by the fine-grained lacustrine deposits in the Lake Dakota Plain on the eastern side of the model. Pilot points in zone HK1_6 represented the moraine northwest of the Elm River that included northwest to southeast lineations. Pilot points in zone HK1_4 represented the meltwater channels along the Elm River and Foot Creek.

Zone HK1_5 is a traditional piecewise-constant zone that represented an area along the edges of glacial moraine that was assumed to contain less permeable sediments than adjacent sand and gravels in the meltwater channels, deltaic deposits, and lacustrine deposits. Zone HK1_9 is a traditional piecewise-constant zone that represented an area on the northwestern side of the Elm River from Westport to zone HK1_7 where the hydraulic gradient in the potentiometric surface was especially steep. Zone HK1_8 represented gravel pits.

Heterogeneity in zones HK1_1, HK1_2, HK1_3, HK1_6, and HK1_ 7 was represented with pilot points (fig. $\overline{36}$ ). Pilot points serve as surrogate parameters at which values are estimated in the parameter estimation process, and their 

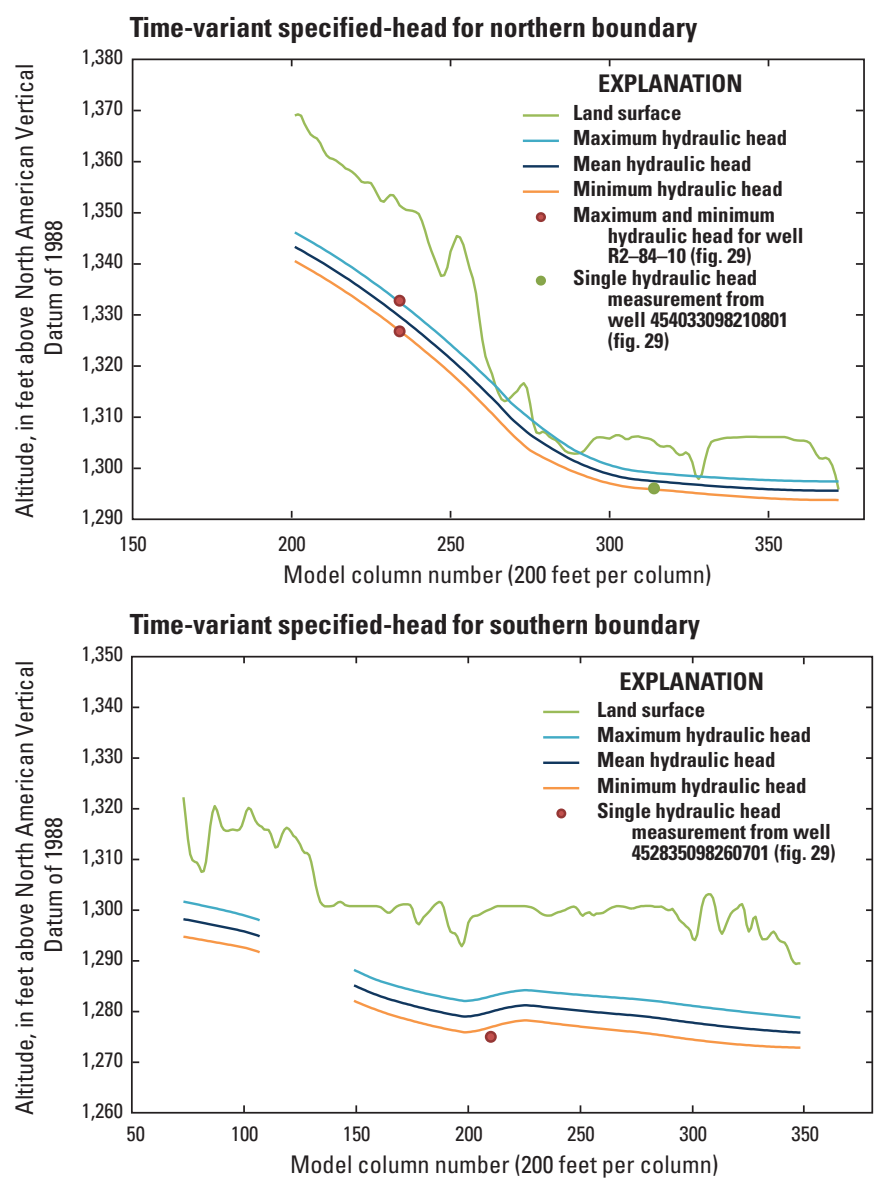

Figure 32. Range in time-variant specified-head boundaries assigned for model layer 2 for all stress periods.

values are interpolated onto the modeling domain (Doherty, 2003; Doherty and others, 2010). Kriging is the method used by PEST for extrapolating values of hydraulic conductivity estimated at the pilot points to the rest of the grid. Kriging assumes the parameters vary in a continuous manner from one pilot-point location to the next. Thus, points that are near each other have a certain degree of spatial correlation as would be expected given the proximity, but values kriged at points that are widely separated are more independent. PEST uses semivariograms to create relations between neighboring pilot points. A semivariogram was defined by Dunlap and Spinazola (1984) as a "graph of the variability of the difference of the regionalization data versus the distance between points." In other words, a semivariogram is a graph of the amount by which two points differ, plotted against the distance between those points. The kriging factors used in the parameter estimation were created on the basis of user-supplied variograms generated with the PEST groundwater utility programs PPK2FAC and FAC2REAL that are explained in the PEST documentation (Doherty, 2008).

An exponential variogram was defined for each of the hydraulic conductivity zones using pilot points. The variograms for zones HK1_1, HK1_2, and HK1_6 included a direction and magnitude of anisotropy. When anisotropy is included in the variogram, the change in hydraulic conductivity between pilot points in the direction of anisotropy is less than between pilot points perpendicular to the direction of anisotropy. Zone HK1_1 was assigned anisotropy with a bearing 32 degrees west of north and a magnitude of 2 on the basis of the outwash channel orientation. Zone HK1_2 was assigned anisotropy with a bearing 28 degrees east of north and a magnitude of 1.5 on the basis of the preferential orientation of sand and gravels deposits along the margins of the recessional moraine, which retreated to the northwest. Zone HK1_6 was assigned anisotropy with a bearing 32 degrees west of north and a magnitude of 2 on the basis of lineations (Leap, 1986) and the shape of the potentiometric surface.

Each of the 359 pilot points was represented as a parameter in the parameter estimation. Tikhonov regularized inversion is an approach in PEST that uses a modeler's softknowledge about the system to obtain a unique calibration from a fundamentally non-unique, highly parameterized model (Doherty and Hunt, 2010). The model-to-observed measurement objective function is augmented with an additional regularized objective function that includes prior information equations that quantifies the deviation of adjacent pilot point values from the modeler's preferred condition. A preferredhomogeneity condition was used for regularization, which gives preference to calibration solutions where the difference between adjacent pilot points is equal to zero (Doherty and Hunt, 2010). This approach establishes homogeneity within the aquifer zone as the preferred parameter condition. The weight for each prior information equation was calculated on the basis of the kriging variograms established for each zone. Groundwater utility programs supplied with PEST (Doherty, 2008) were used to develop the necessary control files for the parameter estimation process. In summary, this approach allowed heterogeneity to be in the hydraulic conductivity array to improve the fit between simulated and observed calibration targets; however, the variability added would only happen if a sufficient improvement in fit was obtained, and the variability could be constrained to hydrogeologically reasonable values by adjusting the tradeoff between the measurement and regularization objective function (Fienen and others, 2009).

Model layers 2 and 3 were assumed to have homogeneous horizontal hydraulic conductivity. The scant data available for these aquifers did not provide adequate information for zonation geometry or the use of pilot points.

The vertical hydraulic conductivity of confining layers was represented with one parameter representing an array multiplier for each entire layer, VKCB1_1 for the upper confining layer and VKCB2_1 for the lower confining layer. The confining layers were initially parameterized using the range in hydraulic conductivity determined for unweathered till from studies in counties near and surrounding Brown County in eastern South Dakota (table 3 ). Both parameters were assigned ranges of about $5 \times 10^{-5}$ to $0.1 \mathrm{ft} / \mathrm{d}$ and were optimized by parameter estimation. 

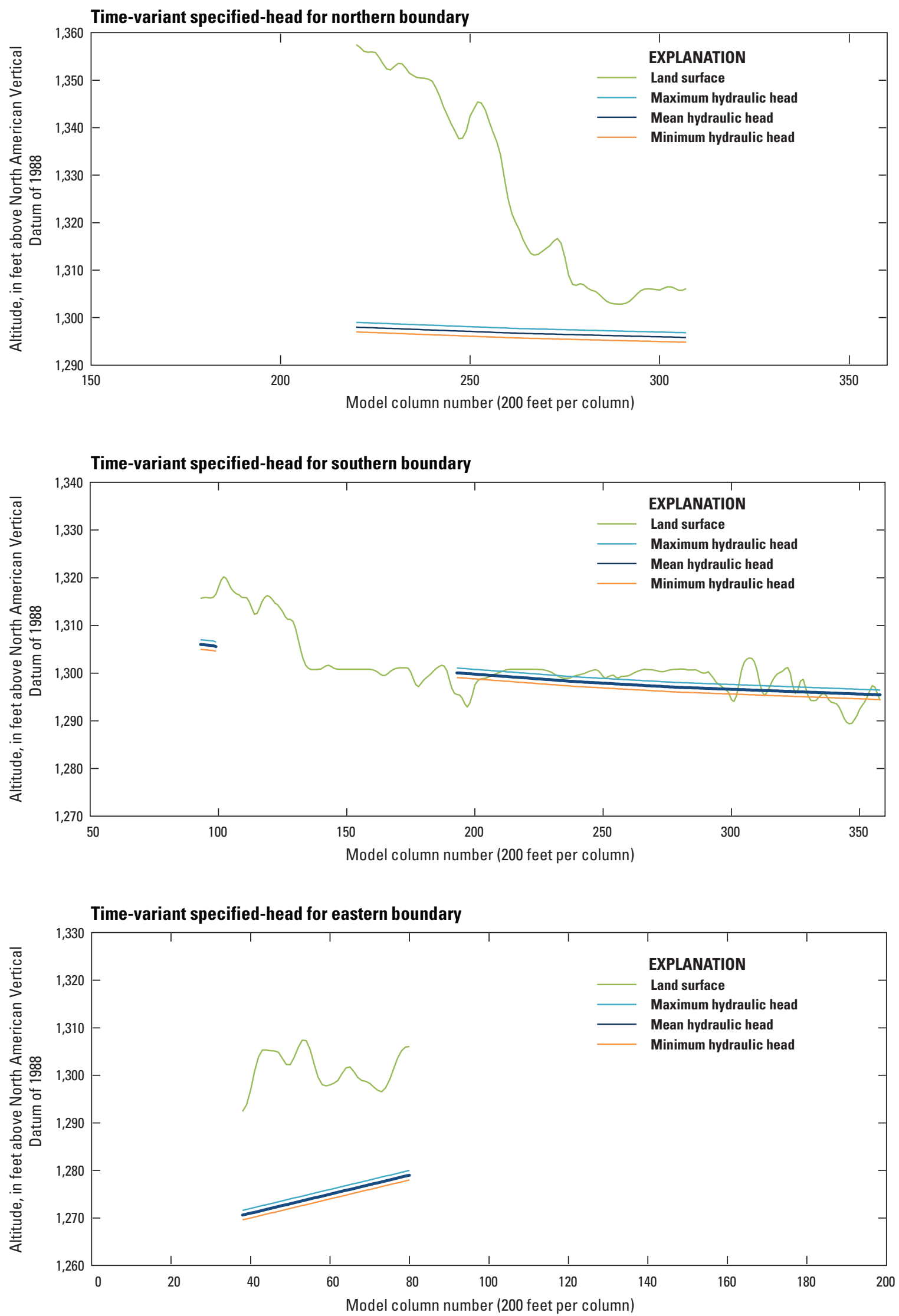

Figure 33. Range in time-variant specified-head boundaries assigned for model layer 3 for all stress periods. 


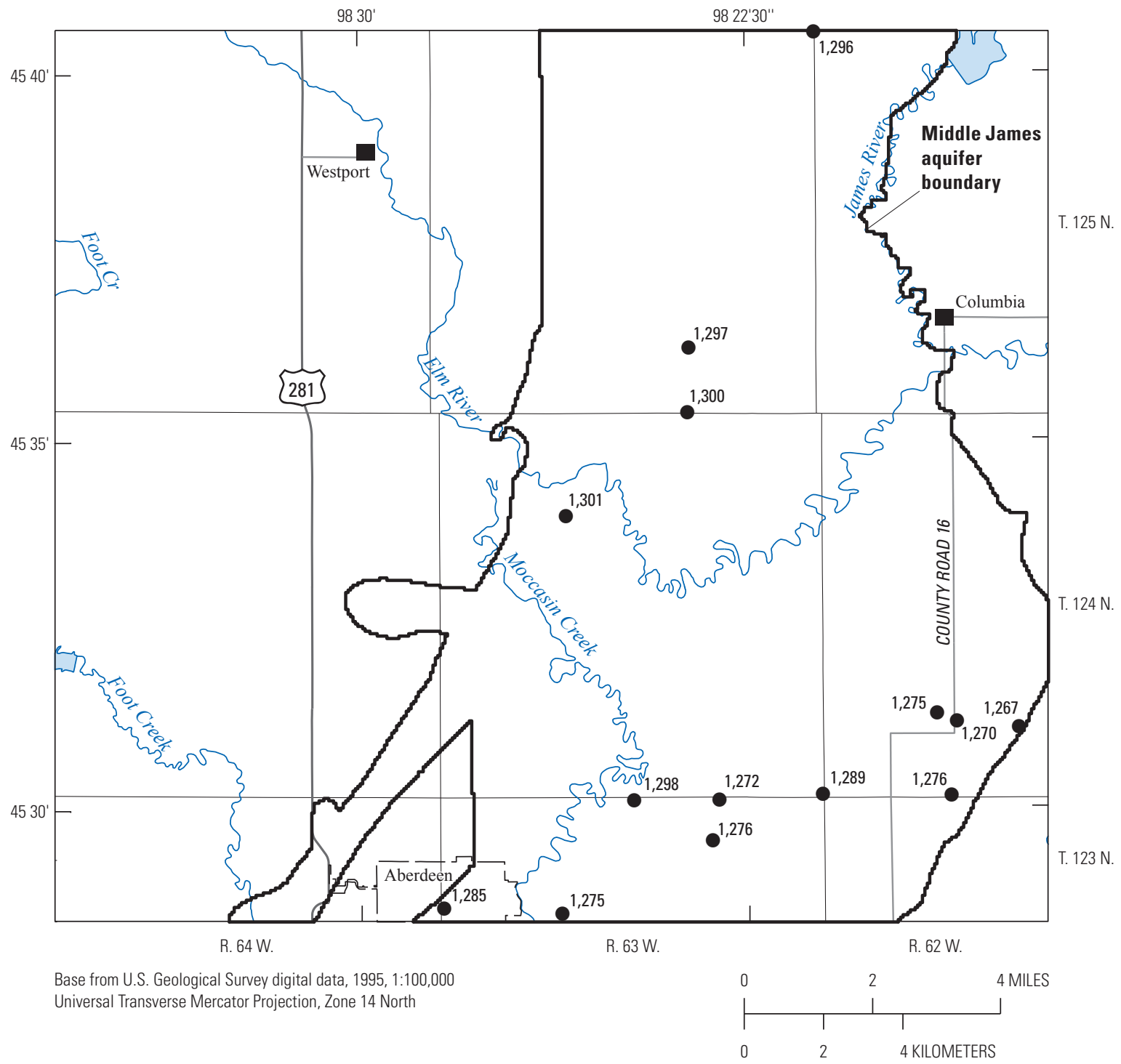

EXPLANATION

1,275-Well-Number is mean altitude of hydraulic head, in feet above North American Vertical Datum of 1988

Figure 34. Mean hydraulic head altitudes for wells completed in the Middle James aquifer (model layer 2). 


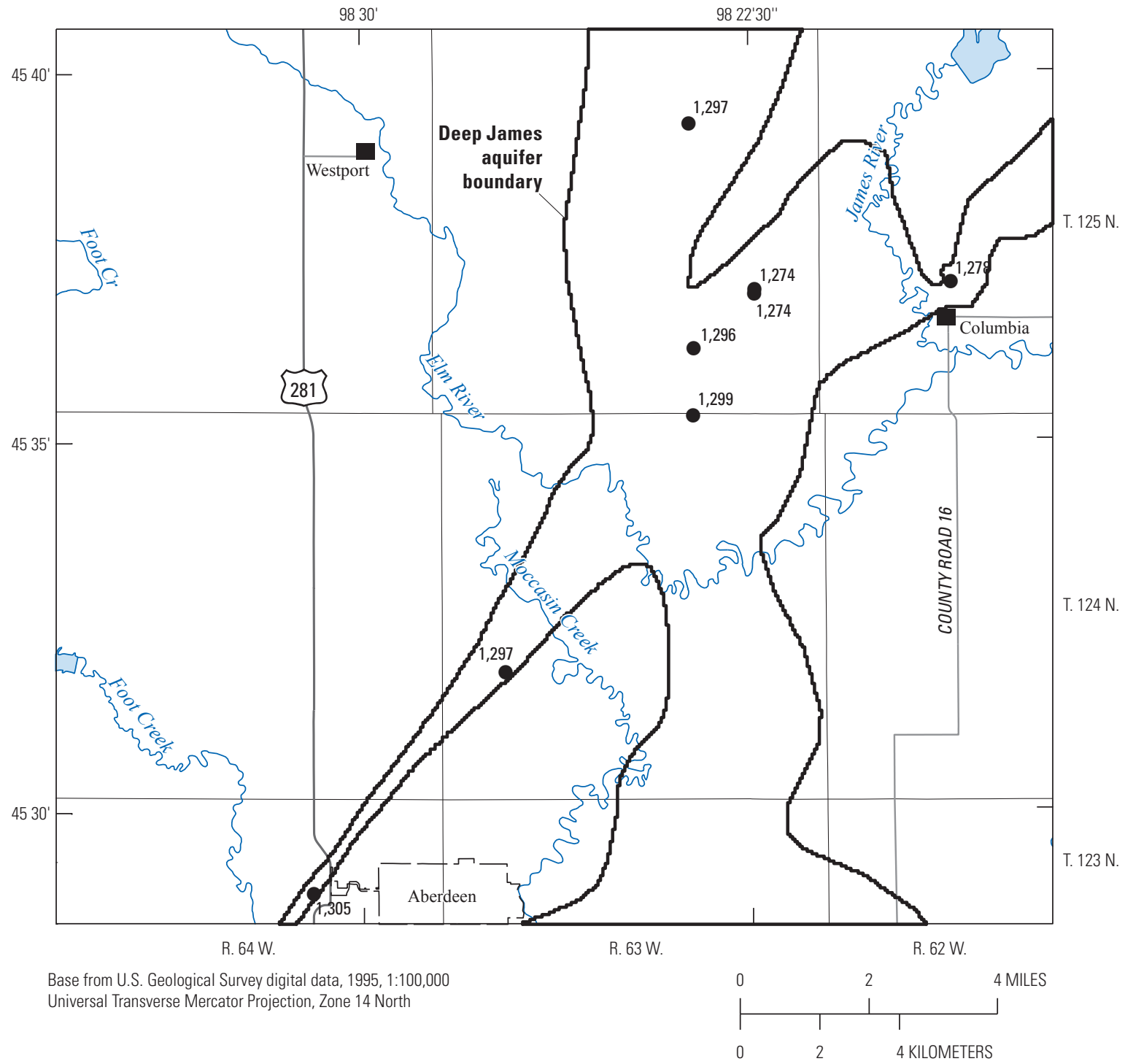

\section{EXPLANATION}

1,297 Well-Number is mean altitude of hydraulic head, in feet above North American Vertical Datum of 1988

Figure 35. Mean of hydraulic head altitudes for wells completed in the Deep James aquifer (model layer 3). 


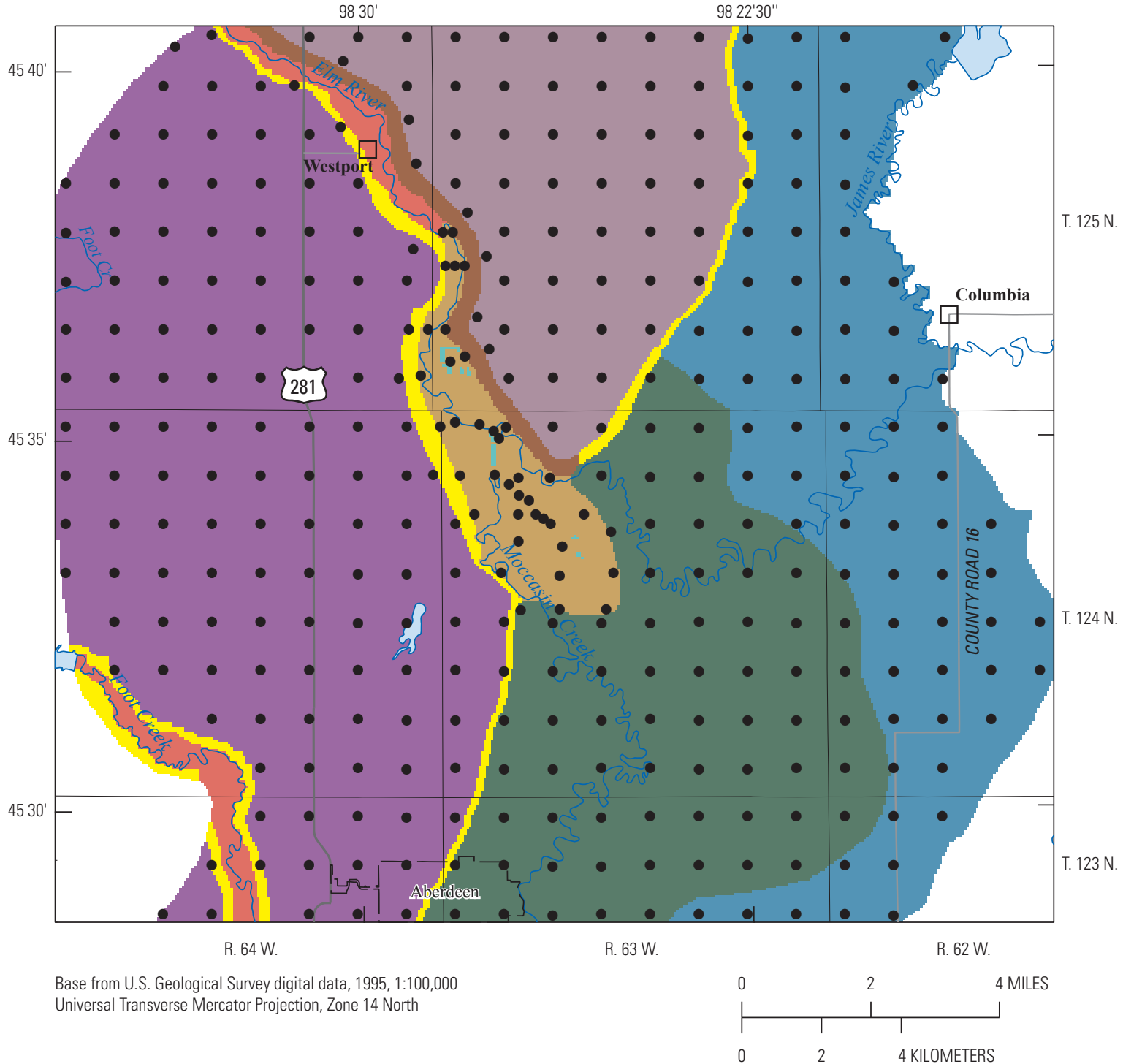

\section{EXPLANATION}

Hydraulic conductivity zones

\begin{tabular}{lll}
\hline HK1_1 & HK1_6 \\
\hline HK1_2 & HK1_7 \\
HK1_3 & HK1_8 \\
\hline HK1_4 & HK1_9 \\
HK1_5 & \\
\hline
\end{tabular}

\section{- Pilot points}

Figure 36. Horizontal hydraulic conductivity zones for model layer 1 and location of pilot points. 
Table 10. Hydraulic conductivity parameter zones representing model layer 1.

\begin{tabular}{|c|c|}
\hline $\begin{array}{c}\text { Parameter } \\
\text { name }\end{array}$ & Parameter description \\
\hline HK1_1 & $\begin{array}{l}\text { Outwash near mouth of Elm River at western edge of ancient Lake Dakota with heterogeneity } \\
\text { approximated with pilot points. }\end{array}$ \\
\hline HK1_2 & $\begin{array}{l}\text { Recessional and ground moraine southwest of Elm River with heterogeneity approximated with } \\
\text { pilot points. }\end{array}$ \\
\hline HK1_3 & Lake Dakota Plain lacustrine deposits with heterogeneity approximated with pilot points. \\
\hline HK1_4 & Outwash channel along Elm River and Foot Creek. \\
\hline HK1_5 & $\begin{array}{l}\text { Transition zone from glacial moraine to outwash channels, deltaic deposits, or lacustrine depos- } \\
\text { its to approximate limited connection between zones. }\end{array}$ \\
\hline HK1_6 & $\begin{array}{l}\text { Recessional and ground moraine northeast of Elm River with heterogeneity approximated with } \\
\text { pilot points. }\end{array}$ \\
\hline HK1_7 & Elm River outwash and delta deposits with heterogeneity approximated with pilot points. \\
\hline HK1_8 & Gravel pits that were assigned a high hydraulic conductivity to approximate the water bodies. \\
\hline HK1_9 & Transition zone on north side of Elm River where the hydraulic gradient is very steep. \\
\hline
\end{tabular}

\section{Representation of Water Budget Components}

Recharge to model layer 1 was estimated by using the SWB method described in Supplement 6. Four multiplier parameters based on the till thickness $(0-10,10-20,20-30$, and greater than $30 \mathrm{ft}$ ) were used to optimize the SWB estimates during the groundwater-model calibration process (fig. 37). The parameter zones were the same as the till thickness zones used in the SWB estimate of recharge (see Supplement 6). The bounds for recharge multiplier parameter $\mathrm{RCH}_{-} \mathrm{TS} 1$ were 0.8 and 1.2 , and the bounds for parameters RCH_TS2 and RCH_TS3 were 0.7 and 1.3 , respectively. Recharge estimates calculated by using the SWB method were most uncertain for parameter RCH_TS4, which represented the area with glacial till greater than $30 \mathrm{ft}$, because this zone represented a large range in till thickness and plausible vertical hydraulic conductivity values. Parameter RCH_TS4 was a multiplier of the SWB estimated recharge value of $0.01 \mathrm{in} / \mathrm{yr}$. The bounds on this parameter were set as 0.5 to 9 to permit larger adjustments in the recharge value for this parameter.

Simulated evapotranspiration from model layer 1 was linearly decreased to an extinction depth of $6 \mathrm{ft}$. The arrays of potential evapotranspiration determined by using the SWB method (Supplement 6) were multiplied by parameter EVT1_ TS, which was optimized by using PEST during the calibration process within a specified range of 0.8 to 1.2.

Elm River and Foot Creek were represented in the model by using the MODFLOW River Package. The river cells were grouped into seven parameter zones (fig. 38) with the vertical conductance of the river cells optimized by parameter estimation. Vertical conductance is the vertical hydraulic conductivity multiplied by the length of the model cell and the width of the river, and divided by the thickness of the sediments separating the river and aquifer. The bounds for the vertical conductance parameters ranged from 0.001 to 0.1 feet squared per second $\left(\mathrm{ft}^{2} / \mathrm{s}\right)$ and were estimated from the calculation of vertical conductance for the cells where temperature (Supplement 5) was used to estimate vertical conductance (table 11; fig. 38).

Moccasin Creek is an intermittent stream that was represented in the model by using the MODFLOW Drain Package (fig. 38). Generally, in the late fall, streamflow in the stream is less than $1 \mathrm{ft}^{3} / \mathrm{s}$ (table 12). The drain vertical conductance was assigned a value of $0.05 \mathrm{ft}^{2} / \mathrm{s}$.

Water use described previously was represented with the MODFLOW Well Package. Pumping withdrawals were averaged for each respective stress period.

\section{Model Calibration}

The numerical model was calibrated by using the PEST parameter estimation program to minimize the sum of the squared weighted residuals ("measurement objective function") for 954 observed (measured) and simulated hydraulic heads. Streamflow ranges described in the "Interaction with Surface Water" section were used to constrain the range in acceptable simulated flow to or from the aquifer to streams by a trial and error process.

Head targets included 135 sites: 113 sites in the Elm aquifer, 14 sites in the Middle James aquifer, and 8 sites in the Deep James aquifer (fig. 39). Hydraulic heads for six SDDENR-WR observation wells completed in the Elm aquifer (BN-77L, BN-77M, BN-77V, BN-82E, BN-82F, and BN-82K; fig. 27), which had synoptic water-level measurements that spanned most of the transient simulation period, were assigned a weight of 1 . Representative head targets were selected from the available data for each stress period for each of the six SDDENR-WR observation wells, resulting in 681 total calibration targets. Wells with a single water-level measurement or a small number of water-level measurements made during the transient simulation period totaled 273 calibration 


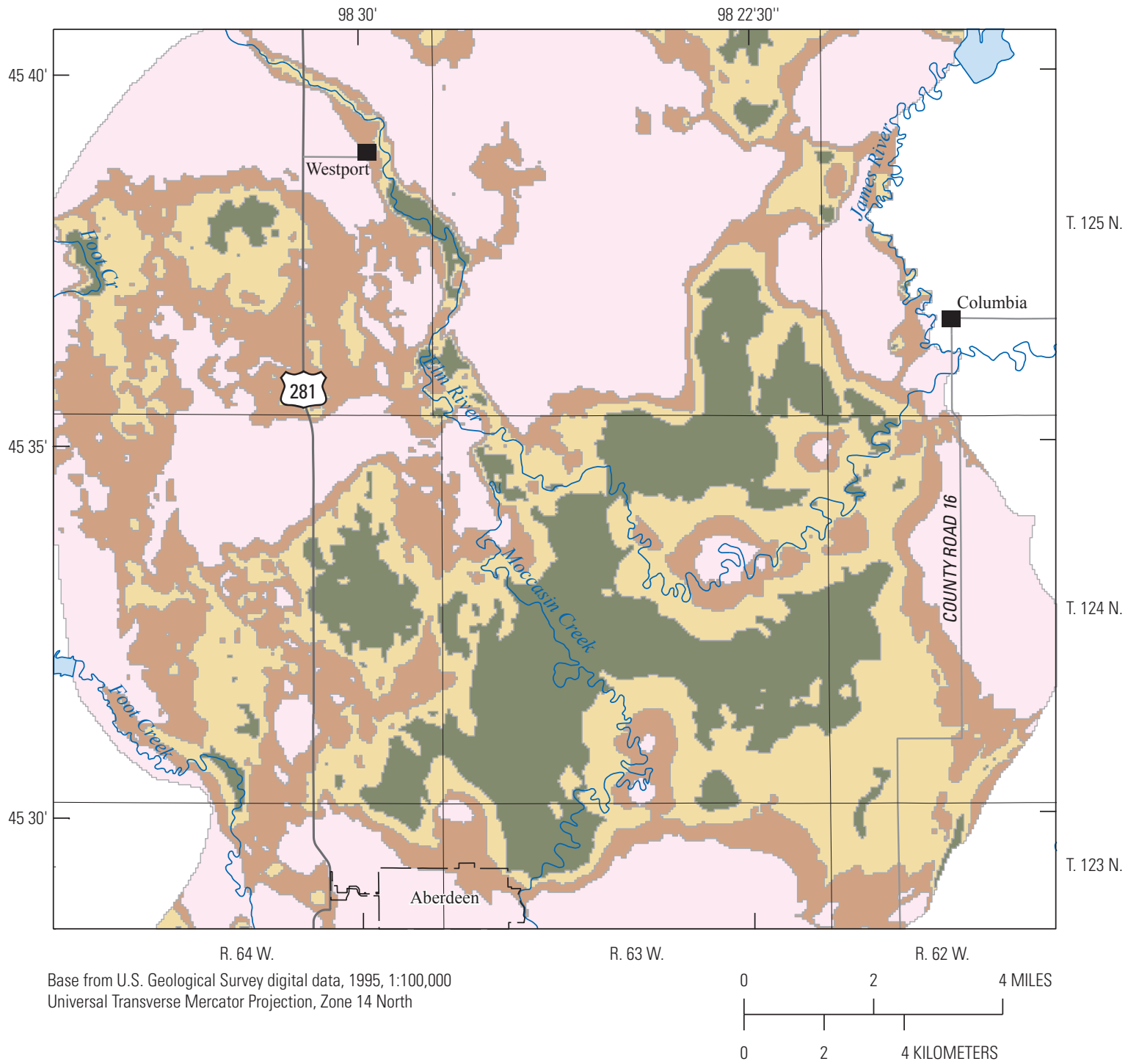

EXPLANATION

Parameter name; till thickness, in feet

RCH TS1; 0 to less than 10

RCH_TS2; 10 to less than 20

RCH_TS3; 20 to less than 30

RCH_TS4; 30 and greater

Figure 37. Distribution of recharge parameters in model area as defined by glacial till thickness. 


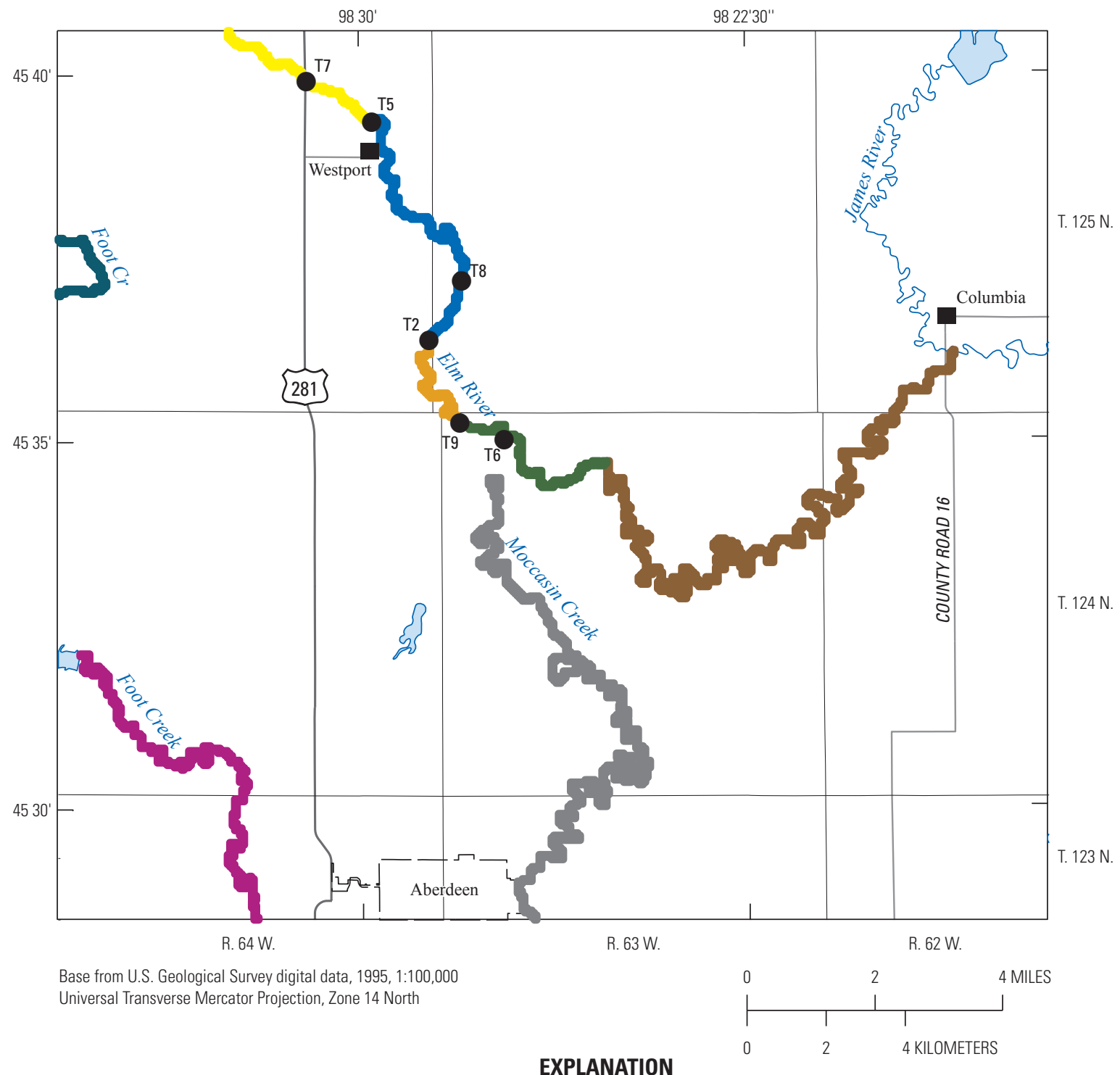

River parameter groups

\begin{tabular}{|c|c|c|}
\hline & RIV1_1 \\
\hline & RIV1_2 \\
& RIV1_3 \\
& RIV1_4 \\
& RIV1_5 \\
& RIV1_6 \\
& RIV1_7 \\
& Drain parameter group \\
& DRN1_1 \\
\hline & Site with vertical conductance estimate with \\
& temperature site identifier
\end{tabular}

Figure 38. Location of vertical conductance sites, river cell parameter groups for Elm River and Foot Creek, and drain cell parameter group for Moccasin Creek. 
Table 11. Vertical conductance at selected sites near Elm River.

\begin{tabular}{cccccccc}
\hline $\begin{array}{c}\text { Temperature } \\
\text { site identifier } \\
\text { (fig. 23) }\end{array}$ & $\begin{array}{c}\text { Adjacent } \\
\text { piezometer } \\
\text { identifier } \\
\text { (fig. 23) }\end{array}$ & $\begin{array}{c}\text { Vertical hydraulic } \\
\text { conductivity } \\
\text { (feet per day) }\end{array}$ & $\begin{array}{c}\text { Thickness of } \\
\text { sediment separating } \\
\text { Elm River and Elm } \\
\text { aquifer } \\
\text { (feet) }\end{array}$ & $\begin{array}{c}\text { River cell } \\
\text { length } \\
\text { (feet) }\end{array}$ & $\begin{array}{c}\text { River width } \\
\text { (feet) }\end{array}$ & $\begin{array}{c}\text { Vertical conductance } \\
\text { (feet squared per } \\
\text { day) }\end{array}$ & $\begin{array}{c}\text { Vertical conductance } \\
\text { (feet squared per } \\
\text { second) }\end{array}$ \\
\hline T2 & PZ8 & 1.00 & 17.8 & 200 & 90 & 1,010 & 0.012 \\
T5 & PZ1 & 2.48 & 9.9 & 200 & 70 & 3,510 & 0.041 \\
T6 & PZ3 & 0.14 & 6.8 & 200 & 120 & 494 & 0.006 \\
T7 & PZ6 & 1.34 & 6.1 & 200 & 50 & 2,200 & 0.025 \\
T8 & PZ7 & 0.28 & 11.2 & 200 & 80 & 400 & 0.005 \\
T9 & PZ9 & 1.62 & 16.1 & 200 & 100 & 2,010 & 0.023 \\
\hline
\end{tabular}

targets. These hydraulic heads were assigned a weight of 2 to increase the importance of these targets in the calibration and to provide spatial balance to the objective function. Estimated average hydraulic heads for 56 wells with water-level measurements made before 1974 were assigned a weight of 1 and used as a calibration target in the starting simulation of average conditions for WY 1975-2009.

Calibration to hydraulic head values alone often result in highly correlated parameters. Flow observations generally decrease the correlation between parameters (Poeter and Hill, 1997). The relatively small flow estimates of a few cubic feet per second of gain or loss described in the "Interaction with Surface Water" section were used to provide trial and error constraints on the calibration. The SWB estimates of the spatial and temporal distribution of fluxes for recharge and evapotranspiration were assumed to provide some constraint on these flows by maintaining the distribution and only optimizing the multiplier of these fluxes in model calibration.

The linear regression for the optimized fit (Helsel and Hirsch, 2002) between the simulated and observed hydraulic heads for all aquifers combined (fig. 40) had a coefficient of determination $\left(\mathrm{R}^{2}\right.$; fraction of the variance explained by

Table 12. Streamflow measurements in the fall at Moccasin Creek at Aberdeen, South Dakota.

[U.S. Geological Survey streamgage 06471770]

\begin{tabular}{cc}
\hline Date & $\begin{array}{c}\text { Streamflow measurement, } \\
\text { in cubic feet per second }\end{array}$ \\
\hline $11 / 15 / 1999$ & 0.30 \\
$11 / 28 / 2000$ & 0.45 \\
$11 / 13 / 2001$ & 0.06 \\
$11 / 14 / 2002$ & 0.05 \\
$12 / 02 / 2003$ & 0.01 \\
$11 / 23 / 2004$ & 0.23 \\
$11 / 10 / 2005$ & 0.04 \\
$10 / 03 / 2006$ & 0.20 \\
$10 / 08 / 2008$ & 0.27 \\
\hline
\end{tabular}

regression) of 0.94 . The mean of the difference between simulated and observed values was $-1.00 \mathrm{ft}$ for all three aquifers combined, with a mean difference of $-1.20 \mathrm{ft}$ for the Elm aquifer, $0.71 \mathrm{ft}$ for the Middle James aquifer, and $4.05 \mathrm{ft}$ for the Deep James aquifer. The mean of the absolute difference between simulated and observed values was $4.21 \mathrm{ft}$ for all three aquifers combined, with a mean of the absolute difference of $4.20 \mathrm{ft}$ for the Elm aquifer, $5.9 \mathrm{ft}$ for the Middle James aquifer, and $4.9 \mathrm{ft}$ for the Deep James aquifer.

For individual sites in model layer 1, the mean of the difference between simulated and observed values was less than plus or minus $10 \mathrm{ft}$ for 87 percent of the sites (fig. 41). The water-level trends for the simulated and observed hydraulic heads for the six SDDENR-WR observation wells (fig. 42) are similar with an average difference of less than $5 \mathrm{ft}$ for 5 of the 6 wells. For well BN-77L, the simulated hydraulic heads averaged about $13 \mathrm{ft}$ less than the observed hydraulic heads. The gradient between $\mathrm{BN}-77 \mathrm{~L}$ and a well completed in the flood plain of the Elm River about 2,500 ft west (fig. 41) was about $35 \mathrm{ft}$. This result may be an artifact of the hydraulic connection between the outwash along the Elm River and the sands and gravels in the glacial moraine being less in this area than is represented in the model. The simulated potentiometric surface for average conditions for WY 1975-2009 shows the general flow direction following the topography from northwest to the southeast with a steep hydraulic gradient towards the Elm River in the northwestern part of the model area. The potentiometric surface in the Lake Dakota Plain reflects the flat topography as indicated by the relatively flat hydraulic gradient.

For sites in model layer 2, the mean of the difference between simulated and observed hydraulic heads was less than plus or minus $10 \mathrm{ft}$ for 75 percent of the sites (fig. 43). The simulated hydraulic heads in the southeastern corner of the model were 10 to $23 \mathrm{ft}$ above observed hydraulic heads. The specification of a no-flow boundary condition in this area of the model likely is responsible for this difference.

For sites in model layer 3, the mean of the difference between simulated and observed values was less than plus or minus $10 \mathrm{ft}$ for 71 percent of the sites (fig. 44). The 


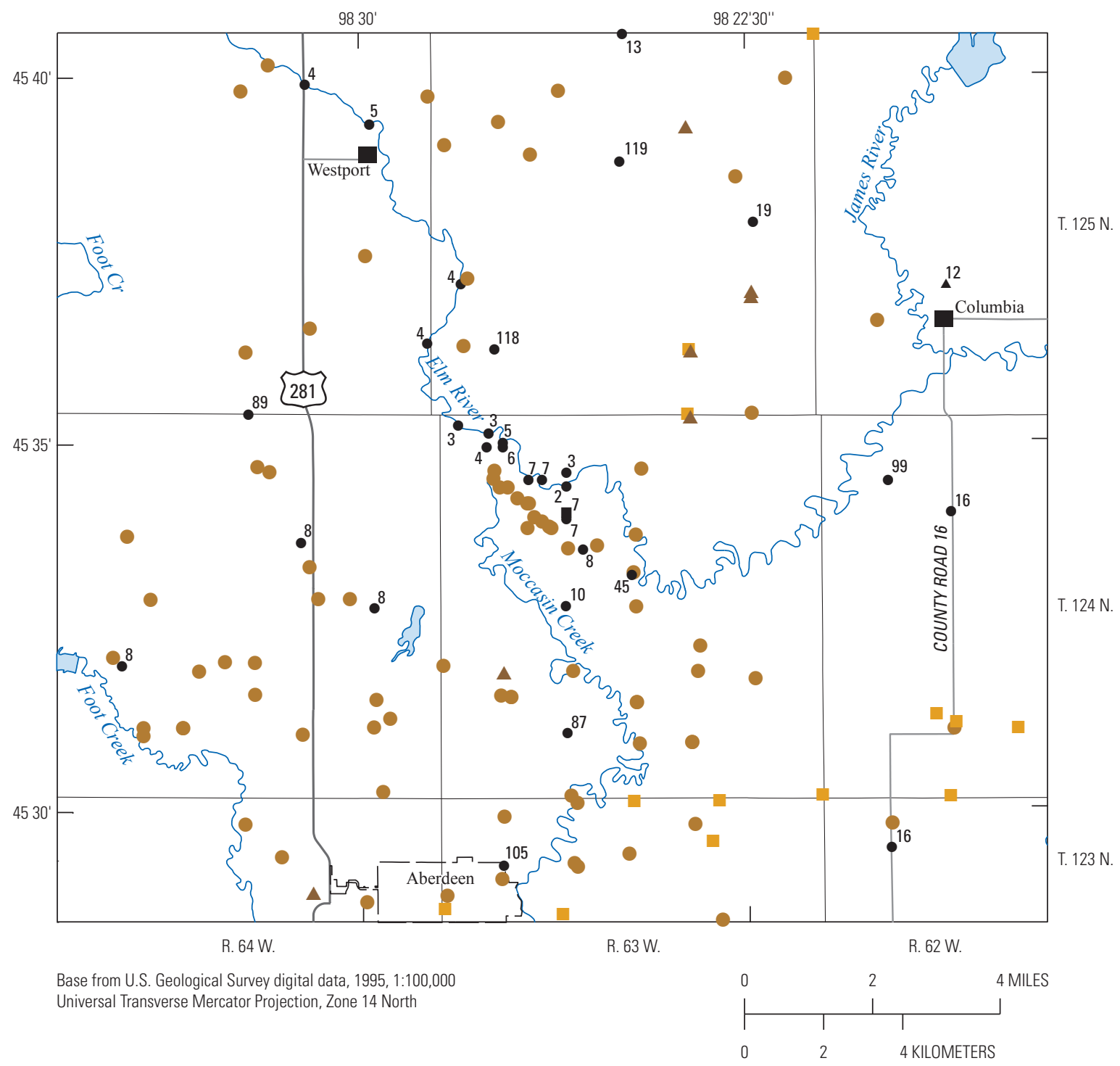

\section{EXPLANATION}

Well with water-level measurement

- Multiple measurements in Elm aquifer-Number is measurement count

- Multiple measurements in Middle James aquifer-Number is measurement count

- Multiple measurements in Deep James aquifer-Number is measurement count

- Single measurement in Elm aquifer

- Single measurement in Middle James aquifer

- Single measurement in Deep James aquifer

Figure 39. Location of wells with water-level data used for model calibration and number of waterlevel measurements per well. 


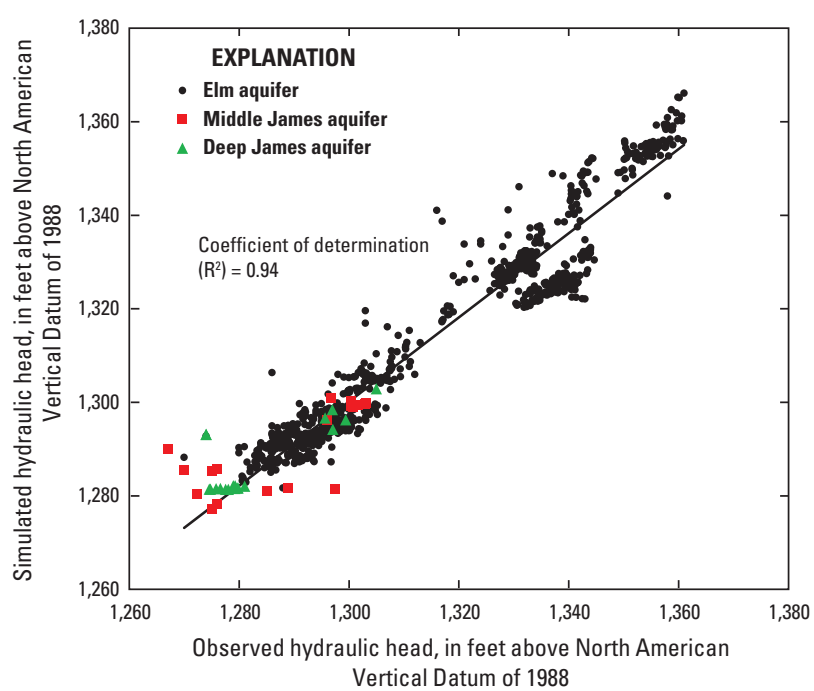

Figure 40. Linear regression between simulated and observed hydraulic heads for all aquifers.

simulated hydraulic heads at two sites were $19 \mathrm{ft}$ higher than observed hydraulic heads. Because of the lack of test holes that fully penetrate the Deep James aquifer, the boundaries are approximate, which in turn can affect the simulated hydraulic heads.

\section{Calibrated Parameters}

Calibrated values were determined for hydraulic conductivity, streambed conductance, recharge rates, and evapotranspiration rates (table 13). Because of the limited flow constraints used in model calibration, alternate combinations of calibrated values also could produce an acceptable fit to the measured data.

Horizontal hydraulic conductivity values for model layer 1 ranged from 2 to $500 \mathrm{ft} / \mathrm{d}$ with a mean of $94 \mathrm{ft} / \mathrm{d}$ (table 13; fig. 45). Zone HK1_8 represented sand pits that were assigned a high horizontal hydraulic conductivity value of $1,728 \mathrm{ft} / \mathrm{d}$. The areas with the highest hydraulic conductivity were outwash channels along the Elm River and Foot Creek. Zone HK1_6 included an area northeast of the Elm River with horizontal hydraulic conductivity values that ranged from 250 to $300 \mathrm{ft} / \mathrm{d}$. Horizontal hydraulic conductivity values for model layers 2 and 3 were 41 and $30 \mathrm{ft} / \mathrm{d}$, respectively.

Vertical hydraulic conductivity values were $0.0002 \mathrm{ft} / \mathrm{d}$ for confining layer 1 and $0.0003 \mathrm{ft} / \mathrm{d}$ for confining layer 2 . Specific yield for model layer 1 was 0.1 , and specific storage was 0.0005 per foot. Specific storage for model layers 2 and 3 were 0.0004 and 0.0003 per foot, respectively. Vertical conductance of the sediments separating the Elm River and Elm aquifer ranged from 87 to $4,320 \mathrm{ft}^{2} / \mathrm{d}$. Calibrated mean recharge rates ranged from $2.5 \mathrm{in} / \mathrm{yr}$ where the glacial till thickness was less than $10 \mathrm{ft}$ to $0.8 \mathrm{in} / \mathrm{yr}$ where glacial till thickness was greater than $30 \mathrm{ft}$. The calibrated mean annual evapotranspiration rate was $8.8 \mathrm{in} / \mathrm{yr}$ (table 13).
Table 13. Calibrated values for model parameters.

$[--$, not applicable $]$

\begin{tabular}{|c|c|c|c|}
\hline $\begin{array}{l}\text { Parameter } \\
\text { name }\end{array}$ & $\begin{array}{c}\text { Minimum } \\
\text { parameter } \\
\text { value }\end{array}$ & $\begin{array}{c}\text { Mean } \\
\text { parameter } \\
\text { value }\end{array}$ & $\begin{array}{c}\text { Maximum } \\
\text { parameter } \\
\text { value }\end{array}$ \\
\hline \multicolumn{4}{|c|}{$\begin{array}{l}\text { Horizontal hydraulic conductivity, in feet per day } \\
\text { (see fig. } 36 \text { for location of hydraulic conductivity zones) }\end{array}$} \\
\hline HK1_1 & 121 & 197 & 382 \\
\hline HK1_2 & 25 & 97 & 52 \\
\hline HK1_3 & 62 & 89 & 141 \\
\hline HK1_4 & -- & 500 & -- \\
\hline HK1_5 & -- & 9 & -- \\
\hline HK1_6 & 56 & 200 & 300 \\
\hline HK1_7 & 30 & 57 & 78 \\
\hline HK1_8 & -- & 1,728 & -- \\
\hline HK1_9 & -- & 2 & -- \\
\hline HK2_1 & -- & 41 & -- \\
\hline HK3_1 & -- & 30 & -- \\
\hline \multicolumn{4}{|c|}{ Vertical hydraulic conductivity, in feet per day } \\
\hline VKA1_1 & -- & 1.0 & -- \\
\hline VKA2_1 & -- & 1.0 & -- \\
\hline VKA3_1 & -- & 1.0 & -- \\
\hline VKCB1_1 & -- & 0.0002 & -- \\
\hline VKCB2_1 & -- & 0.0003 & -- \\
\hline \multicolumn{4}{|c|}{ Specific yield } \\
\hline SY1_1 & -- & 0.1 & -- \\
\hline \multicolumn{4}{|c|}{ Specific storage, in per foot } \\
\hline $\mathrm{SS} 1 \_1$ & -- & 0.0005 & -- \\
\hline $\mathrm{SS} 2 \_1$ & -- & 0.0004 & -- \\
\hline SS3_1 & -- & 0.0003 & -- \\
\hline
\end{tabular}

Vertical conductance of sediments separating streams and Elm aquifer, in feet squared per day (see fig. 38 for location of stream reach)

\begin{tabular}{cccc}
\hline RIV1_1 & -- & 1,378 & -- \\
RIV1_2 & -- & 229 & -- \\
RIV1_3 & -- & 845 & -- \\
RIV1_4 & -- & 1,260 & -- \\
RIV1_5 & -- & 91 & -- \\
RIV1_6 & -- & 87 & -- \\
RIV1_7 & -- & 740 & -- \\
DRN1_1 & -- & 4,320 & -- \\
\hline \multicolumn{4}{c}{ Recharge rate for average condition simulation for water } \\
\multicolumn{5}{r}{ years 1975-2009, in inches per water year } \\
\hline RCH_TS1 & -- & 2.5 & -- \\
RCH_TS2 & -- & 2.0 & -- \\
RCH_TS3 & -- & 1.7 & -- \\
RCH_TS4 & -- & 0.8 & -- \\
\hline Mean annual evapotranspiration rate, in inches per water year \\
\hline EVT1_TS
\end{tabular}




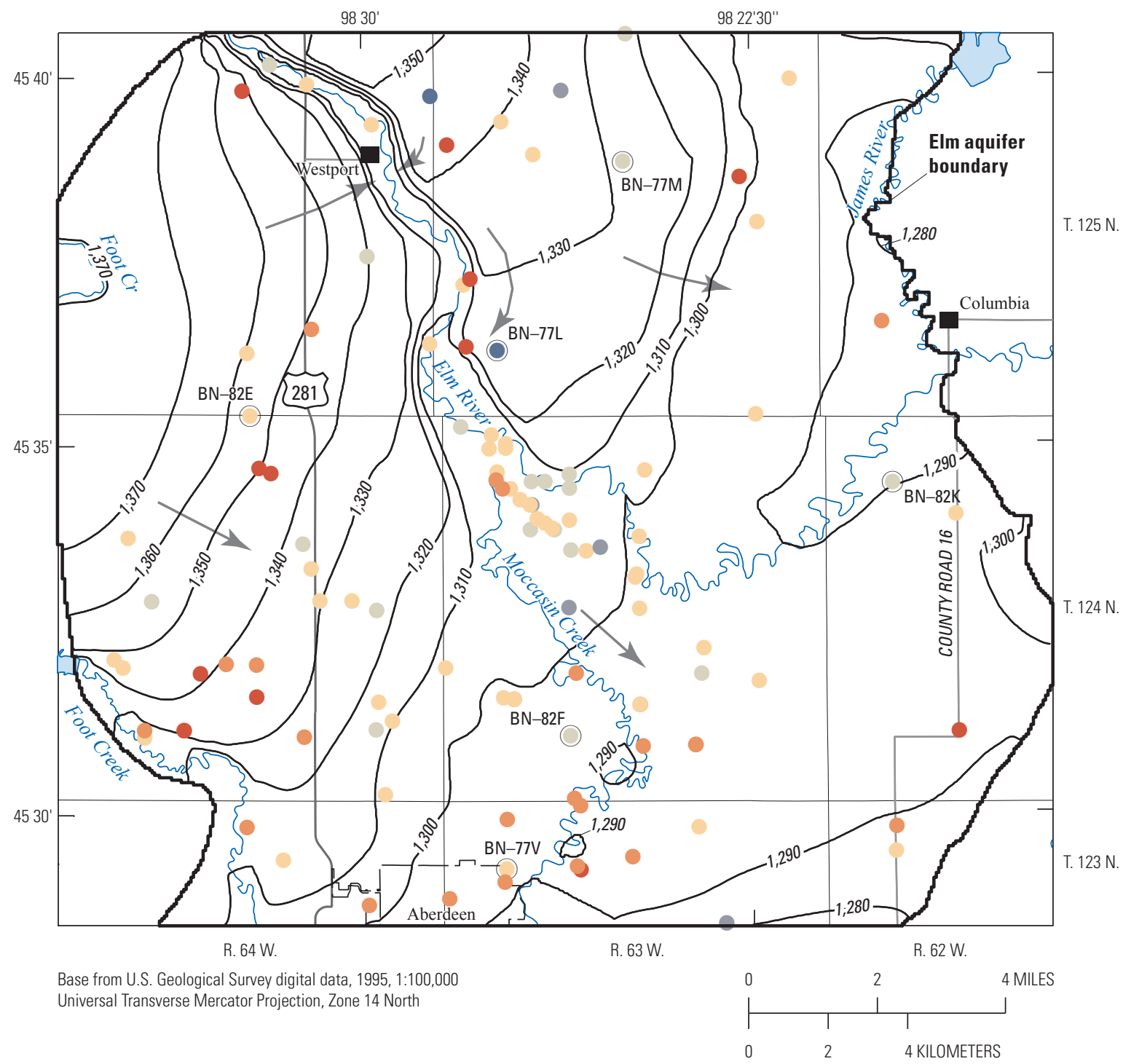

EXPLANATION

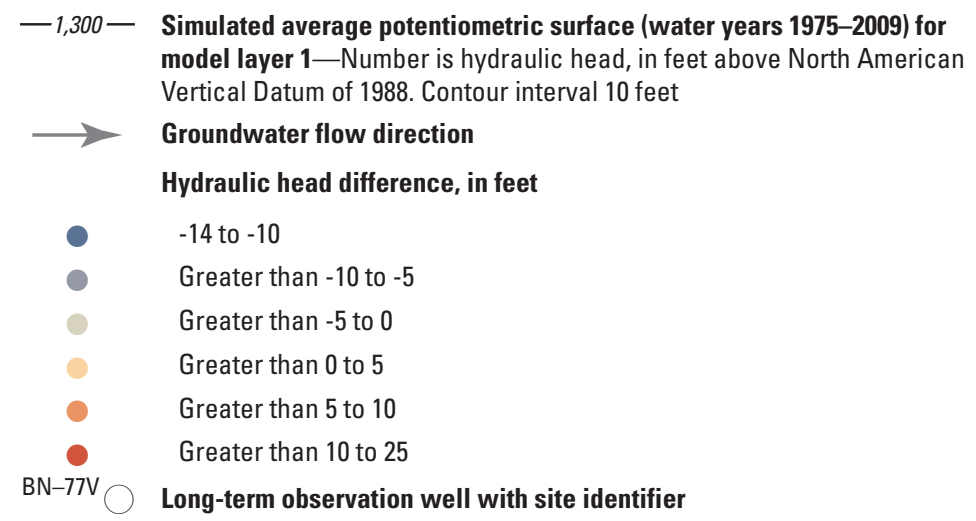

Figure 41. Simulated potentiometric surface for average conditions for water years 1975-2009 and mean difference between simulated and observed transient hydraulic heads for model layer 1 . 

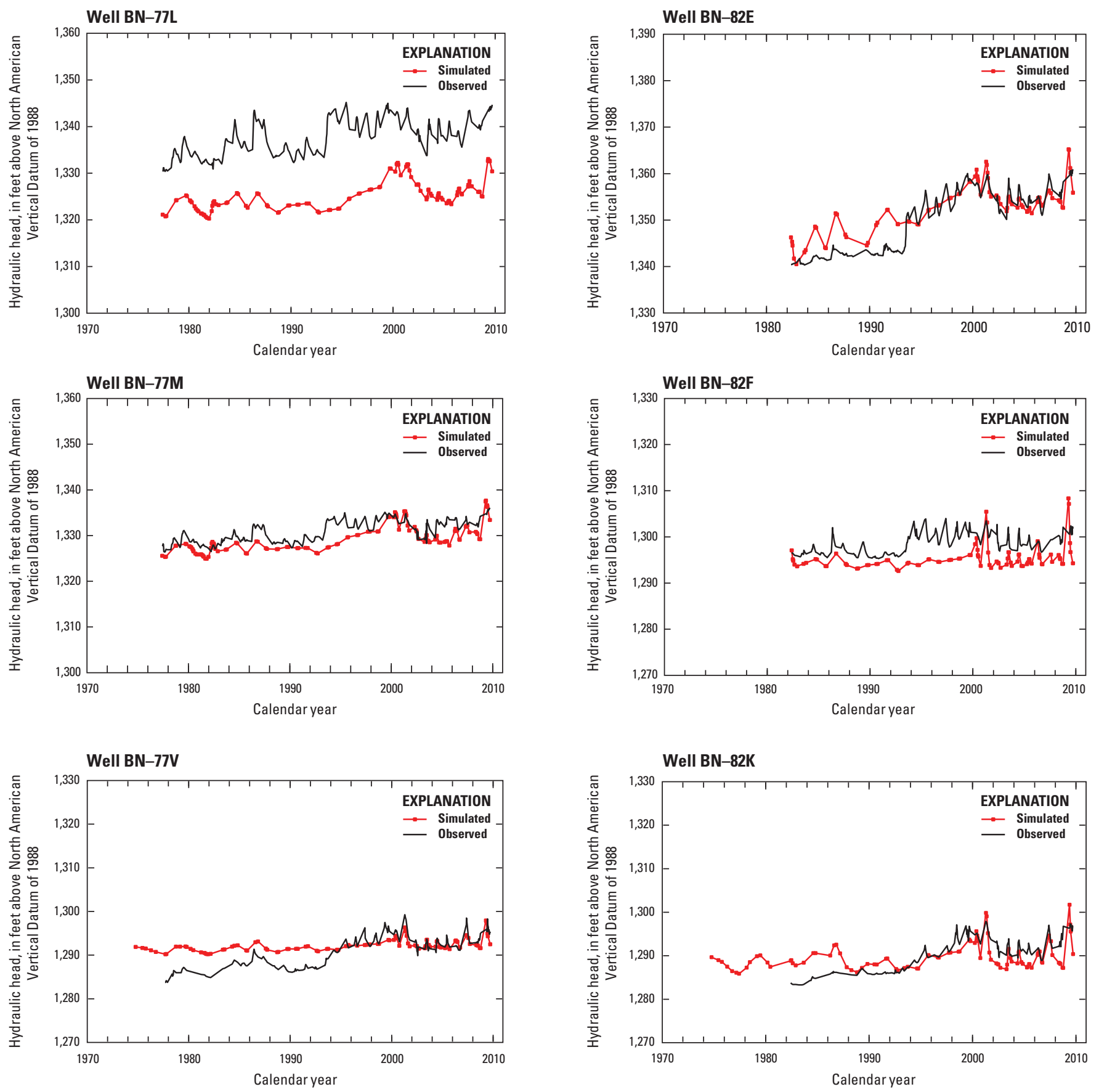

Figure 42. Simulated and observed hydraulic heads for model layer 1 for long-term observation wells. 


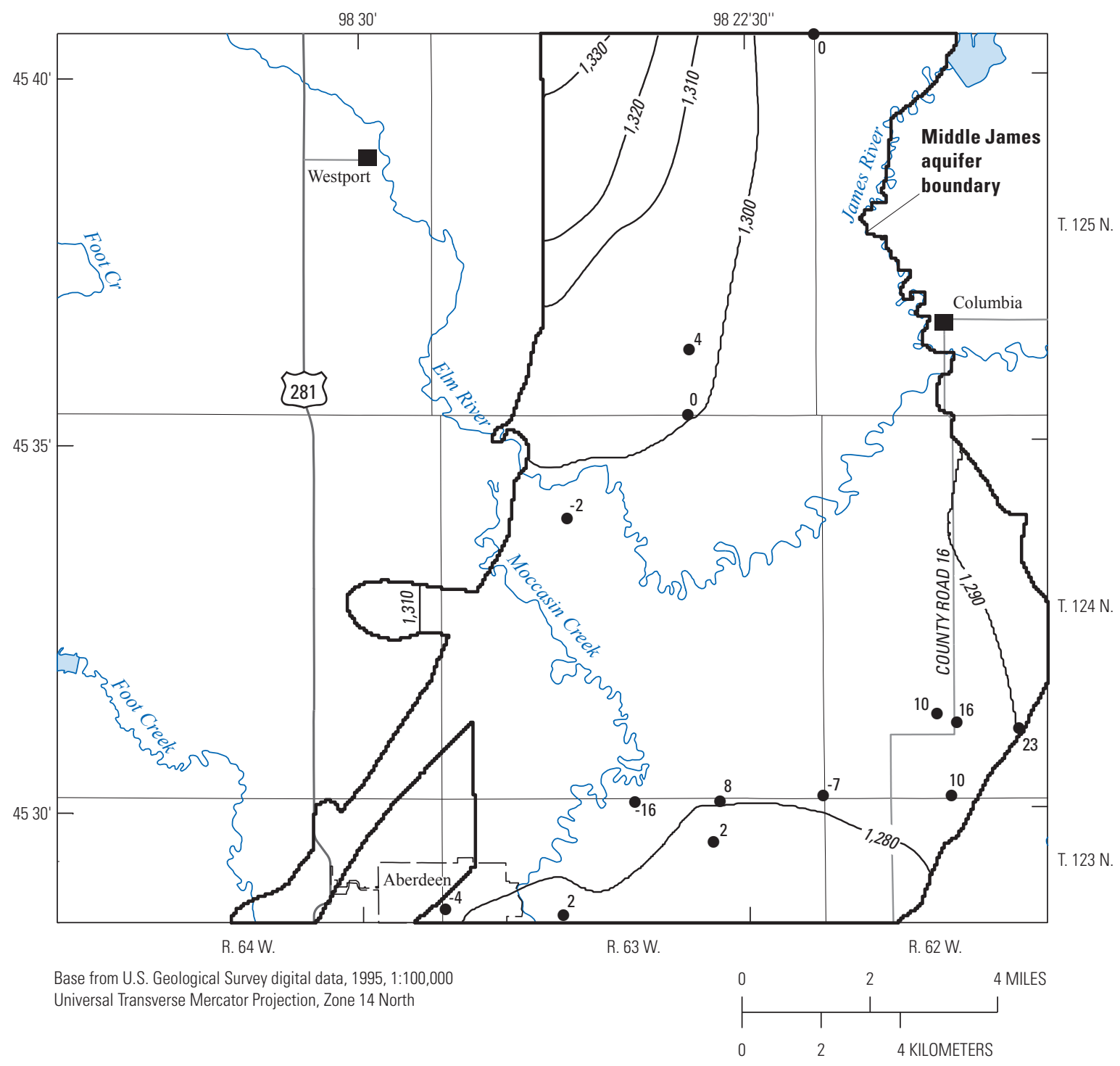

EXPLANATION

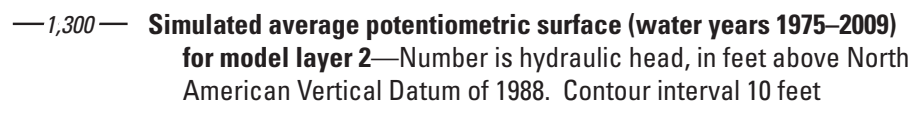

- Well—Number is hydraulic head difference, in feet

Figure 43. Simulated potentiometric surface of average conditions for water years 1975-2009 and mean difference between simulated and observed transient hydraulic heads for model layer 2. 


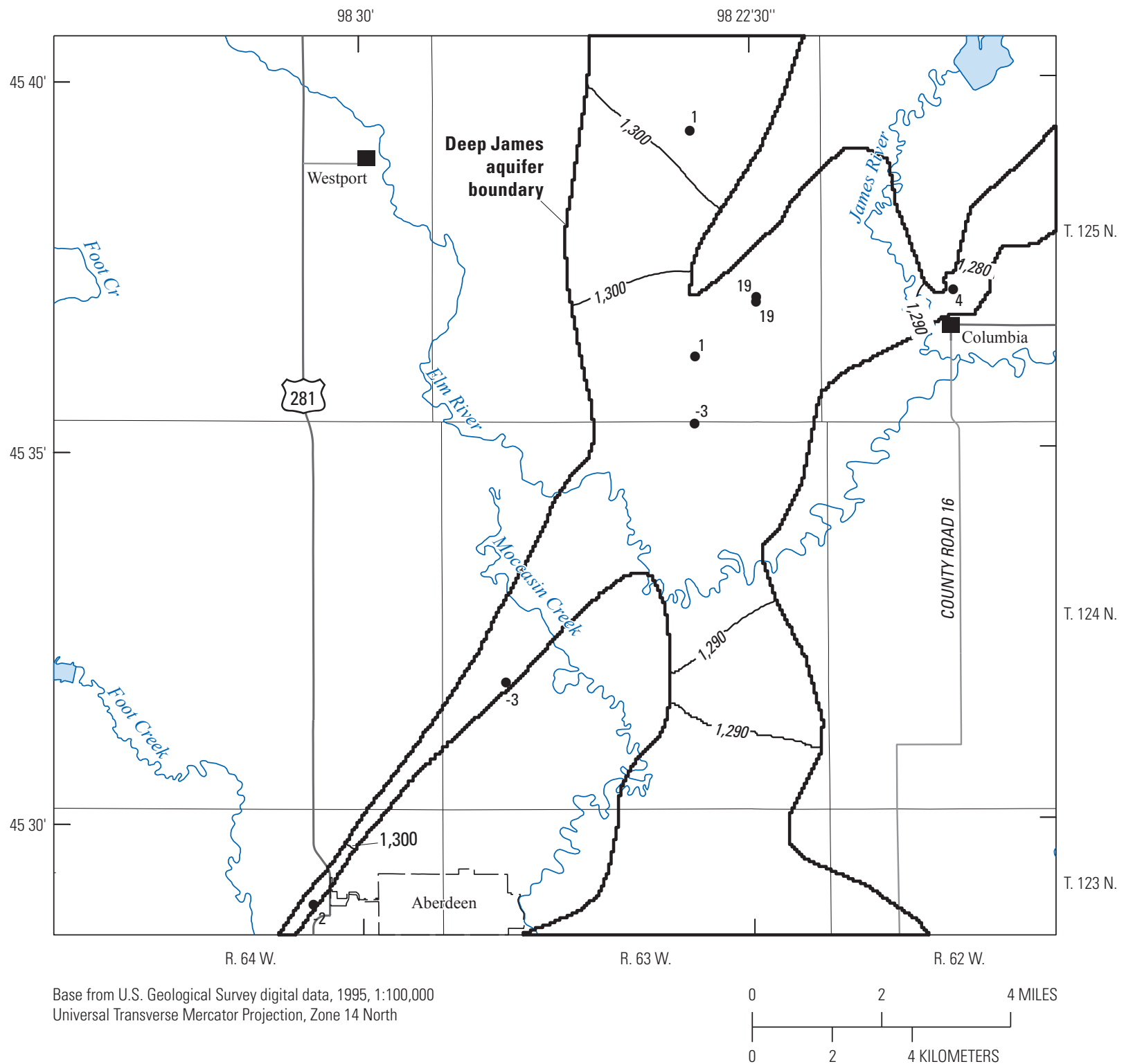

EXPLANATION

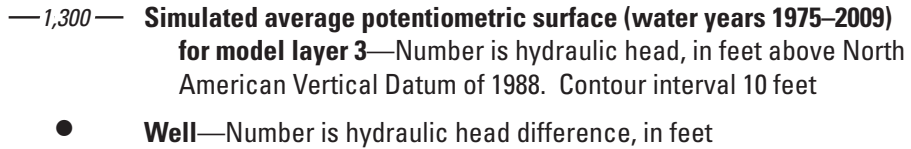

Figure 44. Simulated potentiometric surface of average conditions for water years 1975-2009 and mean difference between simulated and observed transient hydraulic heads for model layer 3. 


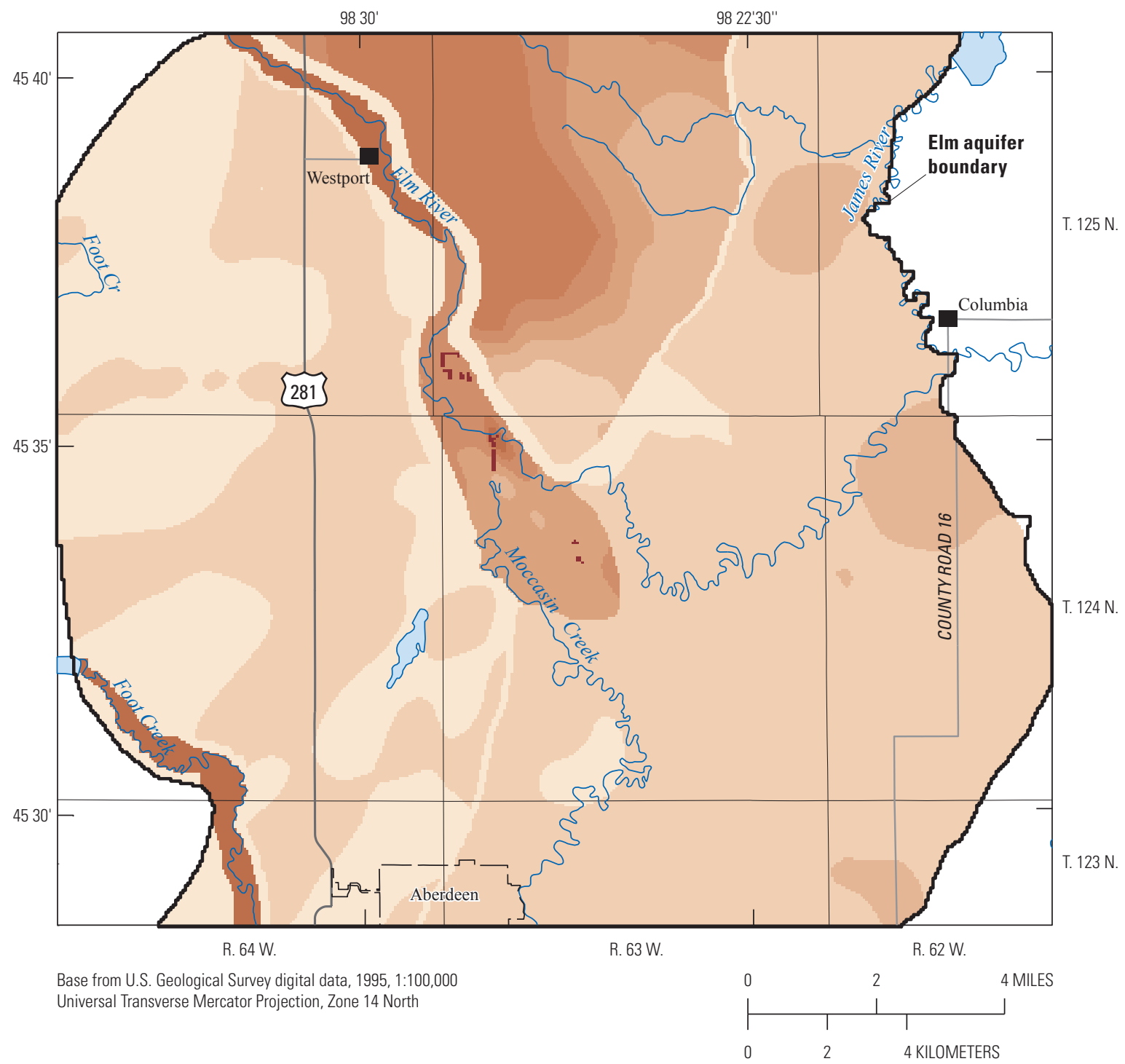

EXPLANATION

Horizontal hydraulic conductivity, in feet per day

2 to 50

Greater than 50 to 100

Greater than 100 to 150

Greater than 150 to 200

Greater than 200 to 250

Greater than 250 to 300

500

1,728

Figure 45. Calibrated horizontal hydraulic conductivity distribution for model layer 1. 


\section{Simulated Water Budget Components}

Recharge and evapotranspiration were the largest components in the simulated water budgets (table 14). Recharge rates by water year ranged from 0.2 to $54.6 \mathrm{ft}^{3} / \mathrm{s}$, and evapotranspiration rates ranged from 4.4 to $34.3 \mathrm{ft}^{3} / \mathrm{s}$ (fig. 46). Changes in evapotranspiration follow changes in recharge with a dampened response. The general direction of groundwater flow is toward the Lake Dakota Plain where the overlying impermeable sediments are relatively thin, and evapotranspiration increases substantially when the water level moves above the evapotranspiration extinction depth of $6 \mathrm{ft}$.

Recharge was optimized by using PEST during model calibration from the SWB estimates through multiplier parameters RCH_TS1, RCH_TS2, RCH_TS3, and RCH_TS4 (table 15), as described in the "Representation of Water Budget Components" section. On the basis of interpolated till thickness, parameters $\mathrm{RCH}_{-} \mathrm{TS} 2$ and $\mathrm{RCH}_{-} \mathrm{TS} 3$ were tied together during calibration with a potential factor range in multiplier of 0.7 to 1.3. A large increase in the recharge rate to zone RCH_TS4, as needed during model calibration, was considered reasonable because the rate estimated by using the SWB method of $0.01 \mathrm{in} / \mathrm{yr}$ was small.

The simulated net groundwater discharge to the Elm River from the Elm aquifer was $3.1 \mathrm{ft}^{3} / \mathrm{s}$. Elm River reaches RIV1_1-RIV1_3 (fig. 38), which are incised in the glacial moraine landform, received discharge from the Elm aquifer with a mean discharge of $2.4 \mathrm{ft}^{3} / \mathrm{s}$ that ranged from 1.7 to $3.7 \mathrm{ft}^{3} / \mathrm{s}$ by water year (fig. 47). The Elm River reach RIV1_4 (fig. 38), which includes the reservoir upstream from Ordway Dam, received discharge from the Elm aquifer with a mean discharge of $0.6 \mathrm{ft}^{3} / \mathrm{s}$ that ranged from 0.0 to $1.0 \mathrm{ft}^{3} / \mathrm{s}$ by water year (fig. 47). These estimates seem plausible on the basis of the streamflow records described in the "Interaction with Surface Water" section. Elm River reach RIV1_5 (fig. 38), which extends from Ordway Dam across the Lake Dakota Plain to the James River, generally lost streamflow to the Elm aquifer with a mean streamflow loss of $0.7 \mathrm{ft}^{3} / \mathrm{s}$ that ranged from 0.3 to $1.6 \mathrm{ft}^{3} / \mathrm{s}$ by water year (fig. 47 ).

The Elm aquifer had small discharges to and gains from Foot Creek that ranged from a loss of $0.6 \mathrm{ft}^{3} / \mathrm{s}$ to a gain of $0.4 \mathrm{ft}^{3} / \mathrm{s}$ by water year, with a mean value of about zero. The

Table 14. Simulated water budgets for water years 1975-2009 (average conditions), water year 1976, and water year 1998.

[Budget component rates in cubic feet per second]

\begin{tabular}{|c|c|c|c|c|c|}
\hline Model layer & Budg & omponent & $\begin{array}{l}\text { Average conditions } \\
\text { (water years } \\
\text { 1975-2009) }\end{array}$ & Water year 1976 & Water year 1998 \\
\hline \multirow[t]{10}{*}{1} & Inflow & Constant head & 2.9 & 3.5 & 2.9 \\
\hline & & Recharge & 21.5 & 2.6 & 28.4 \\
\hline & & From streams & 0.6 & 1.1 & 0.8 \\
\hline & & From layer 2 & 0.1 & 0.2 & 0.1 \\
\hline & Outflow & Constant head & 3.3 & 2.3 & 3.0 \\
\hline & & Evapotranspiration & 16.0 & 7.3 & 20.5 \\
\hline & & To streams & 3.7 & 2.4 & 4.5 \\
\hline & & Wells & 1.3 & 1.8 & 1.8 \\
\hline & & To layer 2 & 0.8 & 0.7 & 0.8 \\
\hline & Change in storage & & 0.0 & -7.1 & 1.6 \\
\hline \multirow[t]{7}{*}{2} & Inflow & Constant head & 0.4 & 0.4 & 0.4 \\
\hline & & From layer 1 & 0.8 & 0.7 & 0.8 \\
\hline & & From layer 3 & 0.1 & 0.1 & 0.1 \\
\hline & Outflow & Constant head & 1.0 & 0.7 & 0.9 \\
\hline & & To layer 1 & 0.1 & 0.2 & 0.1 \\
\hline & & To layer 3 & 0.2 & 0.1 & 0.2 \\
\hline & Change in storage & & 0.0 & -0.1 & 0.1 \\
\hline \multirow[t]{5}{*}{3} & Inflow & Constant head & 0.1 & 0.1 & 0.1 \\
\hline & & From layer 2 & 0.1 & 0.1 & 0.1 \\
\hline & Outflow & Constant head & 0.1 & 0.2 & 0.1 \\
\hline & & To layer 2 & 0.1 & 0.1 & 0.1 \\
\hline & Change in storage & & 0.0 & -0.1 & 0.0 \\
\hline
\end{tabular}




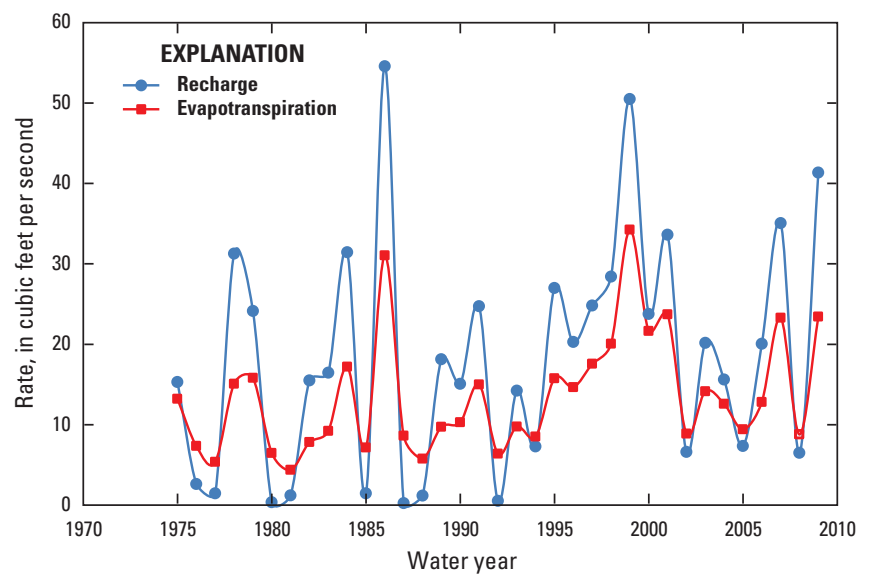

Figure 46. Simulated recharge and evapotranspiration rates by water year.

Elm aquifer discharged to Moccasin Creek with a mean value of $0.5 \mathrm{ft}^{3} / \mathrm{s}$ that ranged from 0.0 to $2.1 \mathrm{ft}^{3} / \mathrm{s}$ by water year. These values were within a plausible range on the basis of the seasonal streamflow records for U.S. Geological Survey streamgage 06471770 (table 7).

\section{Model Limitations}

The model is a mathematical approximation of the real system that is limited by several simplifying assumptions. In a glacial aquifer system, the deposition of sands and gravels within glacial sediments is heterogeneous, and the calibrated properties in the model represent a generalized bulk approximation. The cell size of $200 \mathrm{ft}$ and calibration techniques used in this model permit the representation of some heterogeneity; however, the regularization used in this parameter estimation only allows heterogeneity to be expressed when observed data support it. Given the large areas not characterized by field data, the real hydrologic properties at individual sites could vary widely from those represented in the model.

Some information was available to characterize the hydraulic conductivity distribution in the Elm aquifer; however, aquifer tests only represented a small part of model area. Each cell represented a bulk average hydraulic conductivity for an area of 4,000 square feet $\left(\mathrm{ft}^{2}\right)$. Lithologic information indicated that the hydraulic connection between sand and gravel deposits could be poor in many locations; therefore, the

Table 15. Recharge parameter boundaries and calibrated multiplier values.

\begin{tabular}{cccc}
\hline $\begin{array}{c}\text { Parameter } \\
\text { name } \\
\text { (fig. 35) }\end{array}$ & $\begin{array}{c}\text { Minimum } \\
\text { parameter } \\
\text { value }\end{array}$ & $\begin{array}{c}\text { Maximum } \\
\text { parameter } \\
\text { value }\end{array}$ & $\begin{array}{c}\text { Calibrated } \\
\text { parameter } \\
\text { value }\end{array}$ \\
\hline RCH_TS1 & 0.8 & 1.2 & 0.8 \\
RCH_TS2 & 0.7 & 1.3 & 0.742 \\
RCH_TS3 & 0.7 & 1.3 & 0.742 \\
RCH_TS4 & 0.5 & 9.0 & 8.19 \\
\hline
\end{tabular}

assumption that the aquifer was a continuous porous medium may limit the ability of the model to simulate local stresses. Information to characterize the Middle James and Deep James aquifers was sparse, and as a result the representation of hydraulic properties was generalized.

Vertical hydraulic conductivity estimates for glacial till can vary over several orders of magnitude; therefore, the representation of the vertical hydraulic properties of confining layers is consistent with a general approximation of the regional system. Similarly, the representation of the hydraulic connection between streams and the Elm aquifer was approximate and could vary more widely at a local level. Estimates of recharge and evapotranspiration also were dependent on estimates of the vertical hydraulic properties of the glacial till.

Application of the SWB method improved estimates of the spatial and temporal distribution of recharge and evapotranspiration; however, the representation of the input parameters for the analysis included bulk approximation of many of the input parameters. Numerous wetlands and depressions exist in the model area, and the potential for localized infiltration for some of these areas could be underestimated.

Calibrated values for recharge and hydraulic properties may be non-unique because the flow constraints on calibration were only represented by plausible ranges. Additional combinations of recharge and hydraulic properties also could produce a reasonable fit to measured hydraulic heads. Calibration of the model to hydraulic heads constrains the ratio between the two parameters better than the magnitude of the values.

Boundary conditions were estimated on the basis of sparse information. The time-variant specified-head boundaries on the northern and southern model boundaries were estimated on the basis of regional hydraulic heads with only a few actual measurements of hydraulic head at the boundaries. The

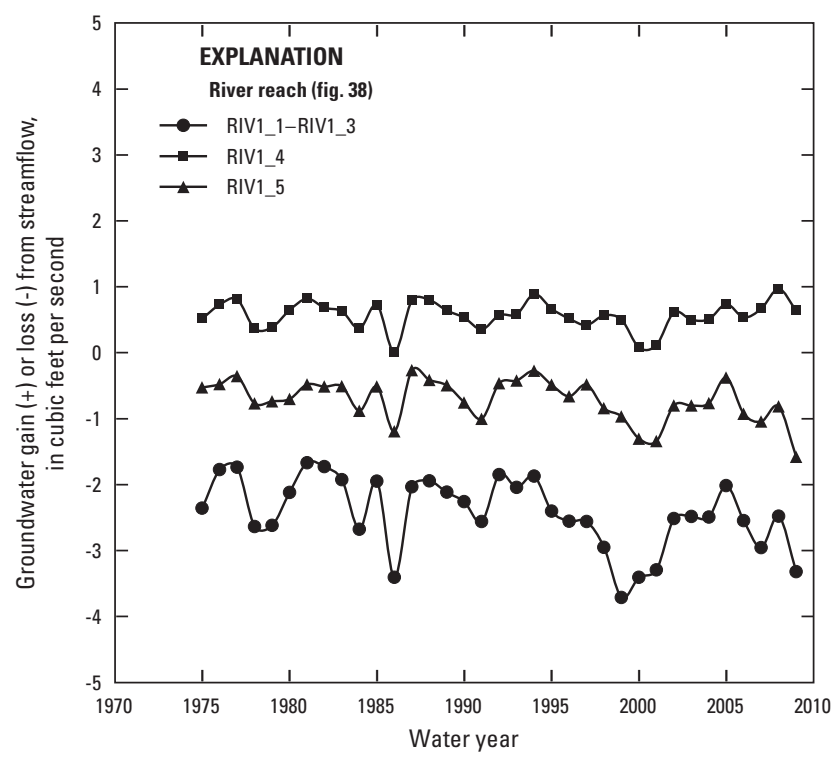

Figure 47. Simulated gain or loss of groundwater in the Elm aquifer along the Elm River. 
boundaries were selected to minimize effects of stresses on the simulation in the areas where future development is anticipated. The approximate boundaries could have more effects when simulating larger stresses and longer periods of time.

The model provides a useful tool to better understand the potential effects of stresses; however, the numerous simplifying assumptions warrant consideration when evaluating management alternatives by using the model. Additional data from the specific area of interest with associated analysis of the local properties will reduce uncertainty in predictions of system response to specific management alternatives.

\section{Summary}

The city of Aberdeen, South Dakota, is developing plans and strategies for a sustainable supply of municipal water with a long-term plan of utilizing a balance of groundwater and surface-water sources. A primary source of surface water for Aberdeen is the Elm River. Groundwater from the Elm aquifer, a shallow glacial aquifer, is used as a supplemental water source in the Aberdeen area. Periodic drought and potential future increases in water use have raised concerns about declining flows in the Elm River and about water-level declines in the small storage reservoirs and the Elm aquifer. To address these concerns, the U.S. Geological Survey, in cooperation with the city of Aberdeen, developed conceptual and numerical models of a glacial aquifer system north of Aberdeen to provide scientific information that will be useful in evaluating and managing the water resources near Aberdeen.

Average annual precipitation in the model area for water year (WY) 1931 to WY 2009 was 19.6 inches per year (in/yr). The major land use in the model area is for agriculture. The most permeable deposits in the 490-square-mile study area, located in the west-central part of Brown County north of Aberdeen, include glacial outwash consisting of sorted gravel, sand, and silt. The outwash deposits within glacial deposits ranged in altitude from 1,400 to 950 feet (ft) and were grouped as the Elm, Middle James, and Deep James aquifers. The Deep James aquifer is contained within a system of ancient river channels.

Recharge to the Elm aquifer is by infiltration of precipitation through overlying outwash, lake sediments, and glacial till. Recharge and discharge to the Middle James and Deep James aquifers primarily is from hydraulic connection to overlying aquifers. Discharge from the Elm aquifer primarily is evapotranspiration and discharge to streams.

The Elm aquifer ranged in thickness from less than 1 to about $95 \mathrm{ft}$, with an average thickness of about $24 \mathrm{ft}$; the Middle James aquifer ranged in thickness from less than 1 to $91 \mathrm{ft}$, with an average thickness of $13 \mathrm{ft}$; and the Deep James aquifer ranged in thickness from less than 1 to $165 \mathrm{ft}$, with an average thickness of $23 \mathrm{ft}$. The confining units between the aquifers consisting of glacial till ranged in thickness from 0 to $280 \mathrm{ft}$. The general direction of water movement in the model area in the Elm aquifer is from northwest to southeast and toward the Elm River and Foot Creek generally following the topography. Groundwater flow in the Middle James aquifer is to the southeast. Sparse data indicated a relatively flat potentiometric surface in the model area for the Deep James aquifer.

Glacial outwash that consists of mostly sand and gravel may have hydraulic conductivities of as much as several hundred feet per day (ft/d), and glacial till may have hydraulic conductivities several orders of magnitude less than $1 \mathrm{ft} / \mathrm{d}$. A horizontal hydraulic conductivity of $418 \mathrm{ft} / \mathrm{d}$ and a confined storage coefficient of $2.4 \times 10^{-5}$ were determined for a simulated 6.5-day aquifer test of a sand pit in the Elm aquifer. Horizontal hydraulic conductivity for the Elm aquifer, determined from analysis of data from seven single-well tests at production wells for a 12-hour period, averaged $143 \mathrm{ft} / \mathrm{d}$ with a range of 97-205 ft/d. Estimates of the vertical hydraulic conductivity of the sediments separating the Elm River from the Elm aquifer at six sites, determined from the analysis of temperature gradients, ranged from 0.14 to $2.48 \mathrm{ft} / \mathrm{d}$.

The annual recharge for the model area, calculated by using a soil-water-balance method for WY 1975-2009, ranged from 0.028 inch in WY 1980 to 4.52 inches in WY 1986, with a mean of 1.56 inches. The annual potential evapotranspiration, calculated by using the soil-water-balance method, ranged from 21.8 inches in WY 1983 to 27.0 inches in WY 1985, with a mean of 24.6 inches. Interaction between the Elm aquifer and surface water happens where intervening glacial till is absent or thin. Water use from the glacial aquifer system primarily is from the Elm aquifer for irrigation, municipal, and suburban water supplies, and the annual water use rate ranged from 1.0 to 2.4 cubic feet per second $\left(\mathrm{ft}^{3} / \mathrm{s}\right)$.

The MODFLOW-2005 numerical model represented the Elm aquifer and saturated sandy units within the Lake Dakota Plain physiographic division, the Middle James aquifer, and the Deep James aquifer as three model layers (layers 1-3, respectively) that were separated by confining layers. Groundwater flow was simulated with 75 stress periods of representative lengths for 35 years beginning October 1, 1974 (WY 1975), and ending September 30, 2009 (WY 2009), with the first stress period representing average conditions for WY 1975-2009. The finite-difference grid consisted of 368 rows and 410 columns, with a cell size of $200 \mathrm{ft}$ on a side. Model boundaries were represented by specified-head boundaries and no-flow boundaries. Properties of the glacial aquifer system were represented by parameters with values optimized by using the parameter estimation code (PEST). The model was calibrated by focusing on minimizing the difference between 954 simulated and observed hydraulic heads for 135 sites: 113 sites in the Elm aquifer, 14 sites in the Middle James aquifer, and 8 sites in the Deep James aquifer. The mean of the difference between observed and simulated hydraulic heads was $-1.00 \mathrm{ft}$ for all three aquifers combined, with means of $-1.20 \mathrm{ft}$ for the Elm aquifer, $0.71 \mathrm{ft}$ for the Middle James aquifer, and $4.05 \mathrm{ft}$ for the Deep James aquifer. The mean of the absolute difference between simulated and observed hydraulic heads was $4.21 \mathrm{ft}$ for all 
three aquifers combined, with a means of $4.20 \mathrm{ft}$ for the Elm aquifer, $5.9 \mathrm{ft}$ for the Middle James aquifer, and $4.9 \mathrm{ft}$ for the Deep James aquifer.

Calibrated horizontal hydraulic conductivity values for model layer 1 ranged from 2 to $500 \mathrm{ft} / \mathrm{d}$, with a mean of $94 \mathrm{ft} / \mathrm{d}$. Horizontal hydraulic conductivity for model layers 2 and 3 were 41 and $30 \mathrm{ft} / \mathrm{d}$, respectively. Vertical hydraulic conductivity was $0.0002 \mathrm{ft} / \mathrm{d}$ for confining layer 1 and $0.0003 \mathrm{ft} / \mathrm{d}$ for confining layer 2 . Specific yield for model layer 1 was 0.1 , and specific storage was 0.0005 per foot. Specific storage for model layers 2 and 3 was 0.0004 and 0.0003 per foot, respectively. Vertical conductance of the sediments separating the Elm River and Elm aquifer ranged from 87 to 4,320 feet squared per day. Calibrated mean recharge rates ranged from $2.5 \mathrm{in} / \mathrm{yr}$ where glacial till thickness was less than $10 \mathrm{ft}$ to $0.8 \mathrm{in} / \mathrm{yr}$ where glacial till thickness was greater than $30 \mathrm{ft}$. The calibrated mean annual evapotranspiration rate was $8.8 \mathrm{in} / \mathrm{yr}$. Recharge rates by water year ranged from 0.2 to $54.6 \mathrm{ft}^{3} / \mathrm{s}$, and evapotranspiration rates ranged from 4.4 to $34.3 \mathrm{ft}^{3} / \mathrm{s}$. The simulated net streamflow gain from model layer 1 was $3.1 \mathrm{ft}^{3} / \mathrm{s}$.

\section{References Cited}

Burger, H.R., Sheehan, A.F., and Jones, C.H., 2006, Introduction to applied geophysics: New York, W. W. Norton and Company, Inc., 554 p.

Canadell, J., Jackson, R.B., Ehleringer, J.R., Mooney, H.A., Sala, O.E., and Schulze, E.D., 1996, Maximum rooting depth of vegetation types at the global scale: Oecologia, v. 108, p. 583-595, accessed January 20, 2011, at http:// www.biology.duke.edu/jackson/oecol96d.pdf.

Constantz, J., and Stonestrom, D.A., 2003, Heat as a tracer of water movement near streams, chap. 1 of Constantz, J., and Stonestrom, D.A., eds., Heat as a tool for studying the movement of ground water near streams: U.S. Geological Survey Circular 1260, p. 2-6. (Also available at http://pubs. usgs.gov/circ/2003/circ1260/.)

Cowman, T.C., 1996, Methodology and results of in-situ permeability tests in unweathered glacial till of South Dakota: South Dakota Geological Survey Open-File Report 3-BAS, 20 p. (Also available at http://www.sdgs.usd.edu/pubs/pdf/ BAS-03.pdf.)

Cravens, S.J., and Ruedisili, L.C., 1987, Water movement in till of east-central South Dakota: Ground Water, v. 25, no. 5, p. 555-561.

Curve Number Work Group, 2004, Hydrologic soil-cover complexes, chap. 9 of National engineering handbook-Part 630 Hydrology: U.S. Department of Agriculture, Natural Resources Conservation Service/Agricultural Research Service (210-VI-NEH), $20 \mathrm{p}$.
Davis, R.K., Iles, D.L., Schaeffer, V.R., Kortran, J.M., Koch, Bill, and Peterson, E.W., 1997, Hydrogeology and hydrochemistry of clayey till at the Sioux Falls landfill, Sioux Falls, South Dakota: South Dakota Geological Survey Open-File Report 9-BAS, 193 p. (Also available at http:// www.sdgs.usd.edu/pubs/pdf/BAS-09.pdf)

Doherty, J., 2005, PEST-Model-independent parameter estimation user manual (5th ed.): Watermark Numerical Computing, variously paged, accessed June 28, 2011, at http://www.pesthomepage.org/files/pestman.pdf.

Doherty, J., 2008, Groundwater data utilities: Brisbane, Australia, Watermark Numerical Computing. (Also available at http://pesthomepage.org/Downloads.php.)

Doherty, J., 2010, PEST, Model-independent parameter estimation-User manual (5th ed., with slight additions): Brisbane, Australia, Watermark Numerical Computing.

Doherty, J.E., Fienen, M.N., and Hunt, R.J., 2010, Approaches to highly parameterized inversion-Pilot-point theory, guidelines, and research directions: U.S. Geological Survey Scientific Investigations Report 2010-5168, 36 p. (Also available at http://pubs.usgs.gov/sir/2010/5168/.)

Doherty, J.E., and Hunt, R.J., 2010, Approaches to highly parameterized inversion-A guide to using PEST for groundwater-model calibration: U.S. Geological Survey Scientific Investigations Report 2010-5169, 59 p. (Also available at http://pubs.usgs.gov/sir/2010/5169/.)

Dunlap, L.E., and Spinazola, J.M., 1984, Interpolating watertable altitudes in west-central Kansas using kriging techniques: U.S. Geological Survey Water-Supply Paper 2238, 19 p., accessed July 8, 2010, at http://pubs.usgs.gov/ wsp/2238/report.pdf.

Emmons, P.J., 1987, Preliminary assessment of potential well yields and the potential for artificial recharge of the Elm and Middle James aquifers in the Aberdeen area, South Dakota: U.S. Geological Survey Water-Resources Investigations Report 87-4017, 33 p. (Also available at http://pubs.usgs. gov/wri/1987/4017/report.pdf.)

Emmons, P.J., 1988, A digital simulation of the glacialaquifer system in Sanborn and parts of Beadle, Miner, Hanson, Davison, and Jerauld Counties, South Dakota: U.S. Geological Survey Water-Resources Investigations Report 87-4082, 59 p. (Also available at http://pubs.usgs. gov/wri/1987/4082/report.pdf.)

Emmons, P.J., 1990, A digital simulation of the glacial-aquifer system in the northern three-fourths of Brown County, South Dakota: U.S. Geological Survey Water-Resources Investigations Report 88-4198, 74 p. (Also available at http://pubs.usgs.gov/wri/1988/4198/report.pdf.) 
Fienen, M.N., Muffles, C.T., and Hunt, R.J., 2009, On constraining pilot point calibration with regularization in PEST: Ground Water, v. 47, no. 6, p. 835-844, doi: $10.1111 /$ j.17456584.2009.00579.x.

Flint, R.F., 1955, Pleistocene geology of eastern South Dakota: U.S. Geological Survey Professional Paper 262, 173 p., accessed November 12, 2009, at http://pubs.usgs. gov/pp/0262/report.pdf.

Freeze, R.A., and Cherry, J.A., 1979, Groundwater: Englewood Cliffs, N.J., Prentice-Hall, Inc., 604 p.

Geophex, Ltd., 2004, GEM-2 operation manual version 3.8: Raleigh, N.C., Geophex, Ltd., 22 p., accessed March 8, 2012, at http://www.geophex.com/Downloads. html.

Harbaugh, A.W., 2005, MODFLOW-2005, The U.S. Geological Survey modular ground-water model-The groundwater flow process: U.S. Geological Survey Techniques and Methods, book 6, chap. A16, variously paged. (Also available at http://pubs.usgs.gov/tm/2005/tm6A16/.)

Helsel, D.R., and Hirsch, R.M., 2002, Statistical methods in water resources: U.S. Geological Survey Techniques of Water-Resources Investigations, book 4, chap. A3, 522 p.

Hill, M.C., 1998, Methods and guidelines for effective model calibration: U.S Geological Survey Water-Resources Investigations Report 98-4005, 90 p.

Huang, H., and Won, I.J., 2003, Real-time resistivity sounding using a handheld broadband electromagnetic sensor: Geophysics, v. 68, no. 4, p. 1,224-1,231.

Kress, W.H., Ball, L.B., Teeple, A.P., and Turco, M.J., 2006, Two-dimensional direct-current resistivity survey to supplement borehole data in ground-water models of the former Blaine Naval Ammunition Depot, Hastings, Nebraska, September 2003: U.S. Geological Survey Data Series 172, 31 p. (Also available at http://pubs.usgs.gov/ds/ds172/.)

Koch, N.C., and Bradford, W., 1976, Geology and water resources of Brown County, South Dakota, Part 2-Water resources: South Dakota Geological Survey Bulletin 25, 53 p. (Also available at http://www.sdgs.usd.edu/pubs/ $p d f / B-25(2) \cdot p d f$.)

Lapham, W.W., 1989, Use of temperature profiles beneath streams to determine rates of vertical ground-water flow and vertical hydraulic conductivity: U.S. Geological Survey Water-Supply Paper 2337, 35 p. (Also available at $h t t p: / /$ pubs.usgs.gov/wsp/2337/report.pdf.)

Leap, D.L., 1986, Geology and water resources of Brown County, South Dakota, Part I-Geology: South Dakota Geological Survey Bulletin 25, 48 p. (Also available at http://www.sdgs.usd.edu/pubs/pdf/B-25(1).pdf.)
Levenberg, K., 1944, A method for the solution of certain non-linear problems in least squares: Quarterly of Applied Mathematics, v. 2, p. 164-168.

Loke, M.H., 1999, Electrical imaging surveys for environmental and engineering studies-A practical guide to 2-D and 3-D surveys: Geometrics, Inc., 57 p., accessed March 8, 2012, at ftp://geom.geometrics.com/pub/ GeoElectric/Literature/Lokenote.pdf.

Loke, M.H., 2010, RES2DINV version 3.59-Rapid 2-D resistivity and IP inversion using the least-squares method: Geoelectrical Imaging 2-D and 3-D, Geotomo Software, 148 p., accessed March 29, 2011, at http://www. geoelectrical.com.

Lucius, J.E., Langer, W.H., and Ellefsen, K.J., 2007, An introduction to using surface geophysics to characterize sand and gravel deposits: U.S. Geological Survey Circular 1310, 33 p., accessed November 13, 2008, at http://pubs.usgs.gov/ circ/2007/1310/.

Mace, R.E., 2001, Estimating transmissivity using specificcapacity data: Austin, Tex., University of Texas at Austin, Bureau of Economic Geology, Geological Circular 01-2, $44 \mathrm{p}$.

Marquardt, D.W., 1963, An algorithm for least-squares estimation of nonlinear parameters: Journal of the Society for Industrial and Applied Mathematics, v. 11, no. 2, p. 431441.

McNeill, J.D., 1980, Electrical conductivity of soils and rocks: Ontario, Canada, Geonics, Ltd., Technical Note TN-5, 22 p.

Multi-Resolution Land Characteristics Consortium, 2011, National land cover database - Conterminous United States NLCD 2006 land cover, 30-m data, accessed January 14, 2011, at http://www.mrlc.gov/nlcd2006_downloads. php.

National Climate Data Center, 2011, Record of climatological observations: National Climatic Data Center, accessed January 13, 2011, at http://www.ncdc.noaa.gov/oa/ncdc.html.

Natural Resources Conservation Service, 2009a, Physical soil properties - Brown County, South Dakota: U.S. Department of Agriculture, Natural Resources Conservation Service, tabular data version 13, 54 p., accessed January 13, 2011, at http://soildatamart.nrcs.usda.gov/State.aspx? State $=S D$.

Natural Resources Conservation Service, 2009b, Water features-Brown County, South Dakota: U.S. Department of Agriculture, Natural Resources Conservation Service, tabular data version 13, 53 p., accessed January 13, 2011, at http://soildatamart.nrcs.usda.gov/State.aspx? State $=S D$.

Poeter, E.P., and Hill, M.C., 1997, Inverse methods-A necessary next step in ground-water modeling: Ground Water, v. 35 , no. 2 , p. $250-260$. 
Reilly, T.E., Franke, O.L., and Bennett, G.D., 1987, The principle of superposition and its application in ground-water hydraulics: U.S. Geological Survey Techniques of WaterResources Investigations, book 3, chap. B6, 28 p. (Also available at $h t t p: / / p u b s . u s g s . g o v / t w r i / t w r i 3-b 6 /$.

Rothrock, E.P., 1955, Ground water reservoirs near Aberdeen, South Dakota: South Dakota Geological Survey Report of Investigations RI-078, 47 p., accessed March 10, 2010, at http://www.sdgs.usd.edu/pubs/pdf/RI-078.pdf.

Schaap, B.D., 2000, Aquifer test to determine hydraulic properties of the Elm aquifer near Aberdeen, South Dakota: U.S. Geological Survey Water-Resources Investigations Report 00-4264, 23 p. (Also available at http://pubs.usgs. gov/wri/wri004264/.)

South Dakota Geological Survey, 2008, Lithologic logs database, accessed November 13, 2008, at http://www.sddenr. net/lithdb/.

Stonestrom, D.A., and Blasch, K.W., 2003, Determining temperature and thermal properties for heat-based studies of surface-water ground-water interactions, in Constantz, J., and Stonestrom, D.A., eds., Heat as a tool for studying the movement of ground water near streams: U.S. Geological Survey Circular 1260, p. 74-80. (Also available at $h t t p: / /$ pubs.usgs.gov/circ/2003/circ1260/.)

Theis, C.V., Brown, R.H., and Meyers, R.R., 1963, Estimating the transmissibility of aquifers from the specific capacity of wells, in Bentall, R., ed., Methods of determining permeability, transmissivity, and drawdown: U.S. Geological Survey Water-Supply Paper 1536-I, p. 331-340. (Also available at $h t t p: / / p u b s . e r . u s g s . g o v / p u b l i c a t i o n / w s p 1536 I$.

Thornthwaite, C.W., and Mather, J.R., 1957, Instructions and tables for computing potential evapotranspiration and the water balance: Centerton, N.J., Laboratory of Climatology, Publications in Climatology, v. 10, no. 3, p. 185-311.
Tipton, M.J., 1977, Ground-water study for the city of Aberdeen: South Dakota Geological Survey Open-File Report 16-UR, 7 p., accessed March 10, 2010, at http://www.sdgs. usd.edu/pubs/pdf/UR-16.pdf.

U.S. Geological Survey, 2006, National Elevation DatasetThe seamless data distribution system (SDDS), accessed January 15, 2010, at http://ned.usgs.gov/.

U.S. Geological Survey, 2010, National Water Information System (NWISWeb) - Groundwater levels for South Dakota, accessed June 1, 2011, at http://nwis.waterdata. usgs.gov/sd/nwis/gwlevels.

U.S. Geological Survey, 2011, National Water Information System (NWISWeb) - USGS surface-water data for South Dakota, accessed March 1, 2011, at http://waterdata.usgs. $\mathrm{gov} / \mathrm{sd} / \mathrm{nwis} / \mathrm{sw}$.

Westenbroek, S.M., Kelson, V.A., Dripps, W.R., Hunt, R.J., and Bradbury, K.R., 2010, SWB-A modified Thornthwaite-Mather soil-water-balance code for estimating groundwater recharge: U.S. Geological Survey Techniques and Methods, book 6, chap. A31, 60 p. (Also available at http://pubs.usgs.gov/tm/tm6-a31/.)

Won, I.J., 1980, A wideband electromagnetic exploration method-Some theoretical and experimental results: Geophysics, v. 45, p. 928-940.

Zohdy, A.A.R., Eaton, G.P., and Mabey, D.R., 1974, Application of surface geophysics to groundwater investigations: U.S. Geological Survey Techniques of Water-Resources Investigations, book 2, chap. D1, 116 p. (Also available at http://pubs.usgs.gov/twri/twri2-d1/.) 
Supplements 1-7 


\section{Supplement 1. Electromagnetic Geophysical Surveys}

This supplemental section describes electromagnetic (EM) geophysical surveys that were conducted to determine the apparent electrical conductivity of the Earth at specific locations. Apparent conductivity (inverse of resistivity) can be used to describe the composition of the underlying materials down to a certain depth, depending on the frequency used. Changes in conductivity commonly are associated with differences between lithological sequences because different geologic materials have unique signatures of conductivity. EM surveys may be useful in the exploration stage for sand and gravel, but may be limited in the ability to produce a detailed characterization of a deposit (Lucius and others, 2007). Lucius and others (2007) provide typical ranges of conductivity for several geologic materials (table S1-1). McNeil (1980) also describes electrical conductivity values of soils and rocks.

Table S1-1. Approximate values and typical ranges of selected properties of some common geologic materials.

[Modified from Lucius and others, 2007. <, less than; >, greater than]

\begin{tabular}{lcc}
\hline \multicolumn{1}{c}{ Material } & $\begin{array}{c}\text { Conductivity, } \\
\text { in millisiemens per } \\
\text { meter }\end{array}$ & $\begin{array}{c}\text { Resistivity, } \\
\text { in ohm-meters }\end{array}$ \\
\hline Soil & $<10$ to $>50$ & $<20$ to $>100$ \\
Dry sand and gravel & $<5$ & $>200$ \\
Saturated sand and gravel & $>20$ & $<50$ \\
Clay & 10 to 200 & 5 to 100 \\
\hline
\end{tabular}

The equipment used for EM surveys was the GEM-2 sensor. The GEM-2 has a fixed coil separation of 5.45 feet ( $\mathrm{ft}$ ) and measures apparent conductivity at various frequencies that can range from 330 hertz $(\mathrm{Hz})$ to 48 kilohertz $(\mathrm{kHz})$ (Geophex, Ltd., 2004). The equipment is designed to be highly portable and easily operated by one person. A typical survey involves walking with the GEM-2 over a predefined grid or known path. Huang and Won (2003) describe several applications of the GEM-2, including mapping overburden overlying nonconductive bedrock, defining the extent of saline ground water, and locating buried objects.

Apparent conductivity can be used to describe the composition of the underlying materials down to a certain depth, depending on the frequency used. This depth of exploration, known as "skin depth," is inversely proportional to frequency (Geophex, Ltd., 2004). A low frequency can travel far through the earth and identify deep structures, whereas a high frequency will identify shallow structures. Geologic materials with higher conductivities "absorb" the EM signal and have smaller integrated depths than lower conductance materials. Thus, areas with thick units of sand and gravel will integrate a much deeper depth than an area that is predominantly clays. At a frequency of $14 \mathrm{kHz}$, the GEM-2 has a penetration depth of about $50-165 \mathrm{ft}$ for a conductivity range of 10-100 millisiemens per meter (mS/m) (Won, 1980).
The penetration depth for the frequency was determined using the following equation (Burger and others, 2006):

$$
\delta=\left(\frac{2}{\mu_{0} \sigma \omega}\right)^{1 / 2}
$$

where

$$
\begin{array}{cc}
\delta & \begin{array}{c}
\text { is skin depth, or depth of penetration, in } \\
\text { meters; }
\end{array} \\
\mu_{0} \quad=\text { magnetic permeability for nonmagnetic } \\
\quad \text { media }=4 \pi \times 10^{-7} \text { Henrys per meter; } \\
\sigma \quad=\text { material conductivity, in siemens per meter; } \\
\omega \quad=2 \pi f=\text { angular frequency of the } \\
\quad \text { electromagnetic field; and } \\
f \quad=\text { frequency, in hertz. }
\end{array}
$$

To develop a method to identify areas with high sand and gravel content, an EM survey was conducted with a GEM-2 sensor over an area with well and test hole logs describing the lithologic records. Data were collected along the survey lines (fig. S1-1) using a frequency of 13,590 Hz. A correlation between measured resistivity and the percentage of sand and gravel from lithologic logs was calculated to identify areas with potentially high sand and gravel composition.

Spatial referencing of data collected on land was accomplished by marking known global positioning system locations in the data file and performing an interpolation routine to create a complete georeferenced dataset. Conductivity readings are recorded 10 times per second and walking velocity was approximately $3-6$ feet per second $(\mathrm{ft} / \mathrm{s})$, yielding a raw data spatial resolution of about $0.3-0.6 \mathrm{ft}$ per reading. Raw data were smoothed using a 20-point running median, and the raw dataset was trimmed by using a 20-point centered average to create the final apparent conductivity values used in analysis. Using every 20th point, the spatial resolution of the processed conductivity data was about $10 \mathrm{ft}$.

The average conductivity was 0.053 siemens per meter $(\mathrm{S} / \mathrm{m})$. To determine an average depth of penetration, one standard deviation $(0.027 \mathrm{~S} / \mathrm{m})$ on either side of the mean conductivity (resulting in 0.026 and $0.080 \mathrm{~S} / \mathrm{m}$ ) was used to calculate a depth range of 50-88 ft. The GEM- 2 records data as conductivity in millisiemens per meter. One-thousand was divided by each conductivity value to obtain resistivity in ohm-meters (ohm-m). The average resistivity was about $19 \mathrm{ohm}-\mathrm{m}$.

Twenty-seven wells or test holes (table S1-2), with lithologic records about $50-88 \mathrm{ft}$ deep and within about 0.05 mile (mi) of a survey line, were selected to compare lithologic composition with resistivity (fig. S1-2). The percentage of sand and gravel in lithologic records was plotted against the interpolated resistivity value for each well location (fig. S1-2). The percentage of sand and gravel was determined by taking the cumulative thickness of all sand and gravel deposits, and dividing that number by the total analyzed depth of the lithologic log. The other primary constituents in the soil were clay and glacial till, but small amounts of topsoil and silt also were present. 


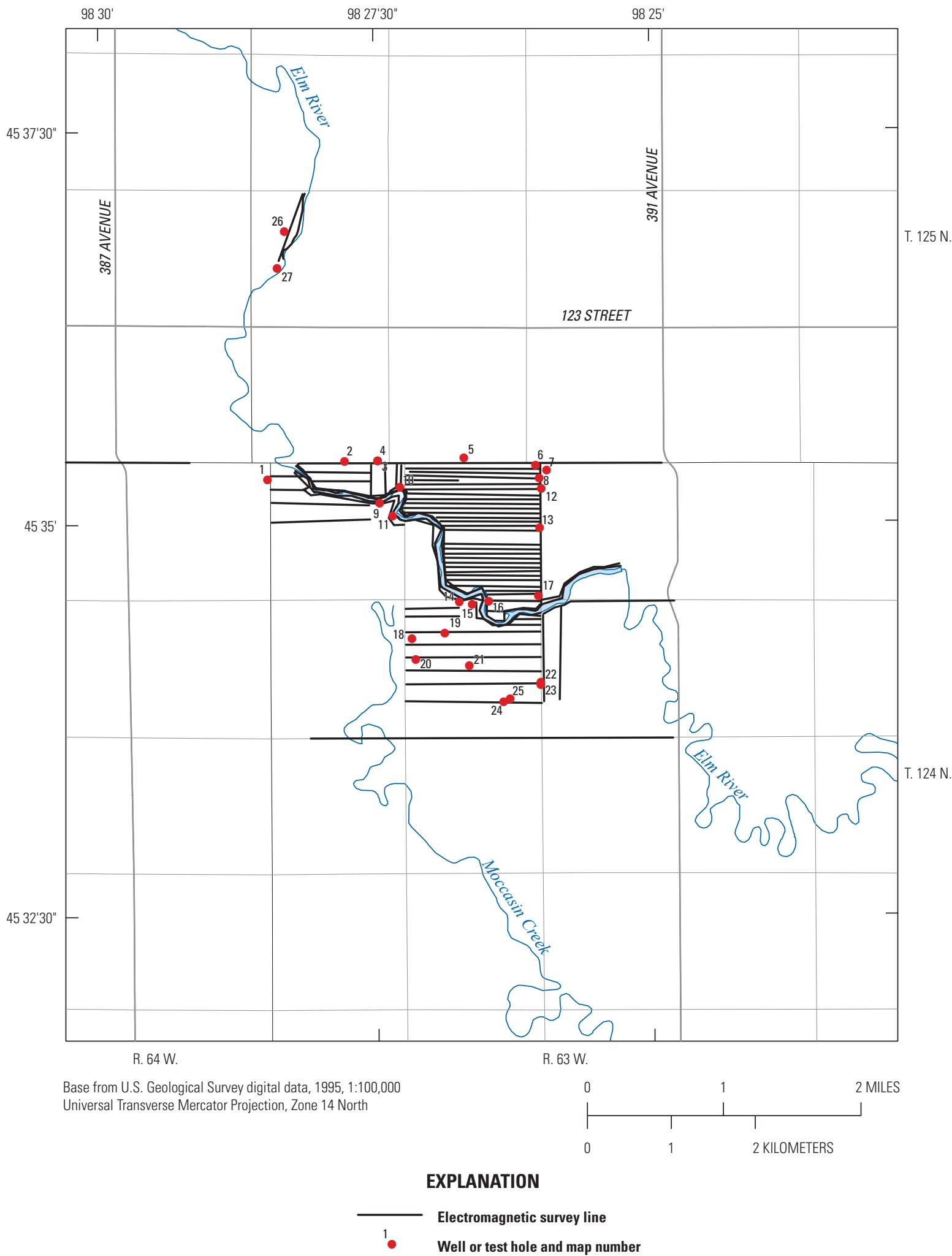

Figure S1-1. Location of electromagnetic survey lines and wells. 
Table S1-2. Station names and depths of lithologic logs that were compared with electromagnetic resistivity surveys.

\begin{tabular}{|c|c|c|}
\hline $\begin{array}{l}\text { Map number } \\
\text { (fig. S1-1) }\end{array}$ & $\begin{array}{l}\text { Lithologic log } \\
\text { station name }\end{array}$ & $\begin{array}{c}\text { Total depth } \\
\text { of lithologic log, in } \\
\text { feet }\end{array}$ \\
\hline 1 & 124N64W01AAAD & 111 \\
\hline 2 & 125N63W31DCDC & 64 \\
\hline 3 & 125N63W31DDDC 1 & 60 \\
\hline 4 & 125N63W31DDDC 2 & 110 \\
\hline 5 & 125N63W32DCCC & 122 \\
\hline 6 & 124N63W05AAAA & 50 \\
\hline 7 & 124N63W04BBBB & 155 \\
\hline 8 & 125N63W05AAAD & 182 \\
\hline 9 & 124N63W06ADBB & 54 \\
\hline 10 & 124N63W06AADA & 38 \\
\hline 11 & 124N63W06AD & 94 \\
\hline 12 & 124N63W04BBCB & 52 \\
\hline 13 & 124N63W05ADDD & 57 \\
\hline 14 & 124N63W08ABBB & 52 \\
\hline 15 & 124N63W08BAAA 1 & 121 \\
\hline 16 & 124N63W08ABBA & 62 \\
\hline 17 & 124N63W05DDDD & 50 \\
\hline 18 & 124N63W08BCBB & 50 \\
\hline 19 & 124N63W08BDBB & 52 \\
\hline 20 & 124N63W08BCC & 90 \\
\hline 21 & 124N63W08BDD & 46 \\
\hline 22 & 124N63W08DAAD 1 & 107 \\
\hline 23 & 124N63W08DAAD 2 & 47 \\
\hline 24 & 124N63W08DBC & 57 \\
\hline 25 & 124N63W08DBD & 47 \\
\hline 26 & 125N63W30BCAA & 59 \\
\hline 27 & $125 \mathrm{~N} 63 \mathrm{~W} 30 \mathrm{CBAB}$ & 77 \\
\hline
\end{tabular}

A logarithmic trend line was fitted to the dataset. The coefficient of determination $\left(\mathrm{R}^{2}\right)$ was determined to be 0.3565 , with the trend line equation of $y=17.993 \ln (x)-6.4899$, where $y$ is the percentage of sand and gravel and $x$ is the resistivity. The relation indicates that resistivity greater than $35 \mathrm{ohm}-\mathrm{m}$ at a frequency of $13,590 \mathrm{~Hz}$ results in a sand and gravel composition of at least 50 percent. The percentage of sand and gravel when the resistivity was less than $35 \mathrm{ohm}-\mathrm{m}$ included a large range, which probably was related to the relative location of clay layers and variability in skin depth.

Resistivity values were interpolated over the area. The natural neighbor spatial analyst tool in ESRI's ArcMap software (http://www.esri.com/ software/arcgis/index.html) was used to perform the interpolation at a 30 -meter (m) pixel size. The resistivity distribution was interpolated using bins of less than 35 ohm-m, 35-60 ohm-m, 60-100 ohm-m, and greater than 100 ohm-m (fig. S1-3).

High resistivity values denoting a high percentage of sand and gravel (fig. S1-3) in the south-central part of the area analyzed correspond to the location of several production wells and the glacial meltwater channel (Leap, 1986) associated with the Elm River (fig. 5). This high apparent resistivity area seems to extend northwest toward Eyestone Pit (fig. 22).

In the area analyzed, the clay commonly was interbedded with the sand and gravel layers at intervals ranging from $2 \mathrm{ft}$ to more than $50 \mathrm{ft}$. This layering in areas with more clay content also results in more variability in the skin depth. The higher resistivity values indicate fewer clay layers interbedded within the sand and gravel and generally greater thickness of sand and gravel. This is consistent with the examined lithologic records, which show predominantly sand and gravel with minute traces of thin clay beds in areas with higher resistivity values.

The two survey lines adjacent to the Elm River and about $2 \mathrm{mi}$ to the northeast of the primary EM survey area (fig. S1-1) indicate resistivity values of less than $35 \mathrm{ohm}-\mathrm{m}$ adjacent to resistivity values of $35-60 \mathrm{ohm}-\mathrm{m}$. This is consistent with the other resistivity data along Elm River, where resistivities of less than $35 \mathrm{ohm}-\mathrm{m}$ are intermingled with resistivities of 35-60 ohm-m, indicating substantial heterogeneity in the sand and gravels along the Elm River.

Because of the uncertainty in skin depth, the GEM-2 EM surveys were limited in characterizing areas of sand and gravel that had substantial interbedded clays; however, areas with apparent resistivity values greater than $35 \mathrm{ohm}-\mathrm{m}$ in the Elm aquifer indicate a high probability for the presence of substantial sand and gravel. The location and trend of the higher apparent resistivity values in the area surveyed is consistent with the meltwater channel described by Leap (1986). The apparent resistivity along the Elm River indicates that hydraulic connection of the river to the Elm aquifer may be limited by clay layers of variable thickness with interspersed areas that have a higher probability of hydraulic connection.

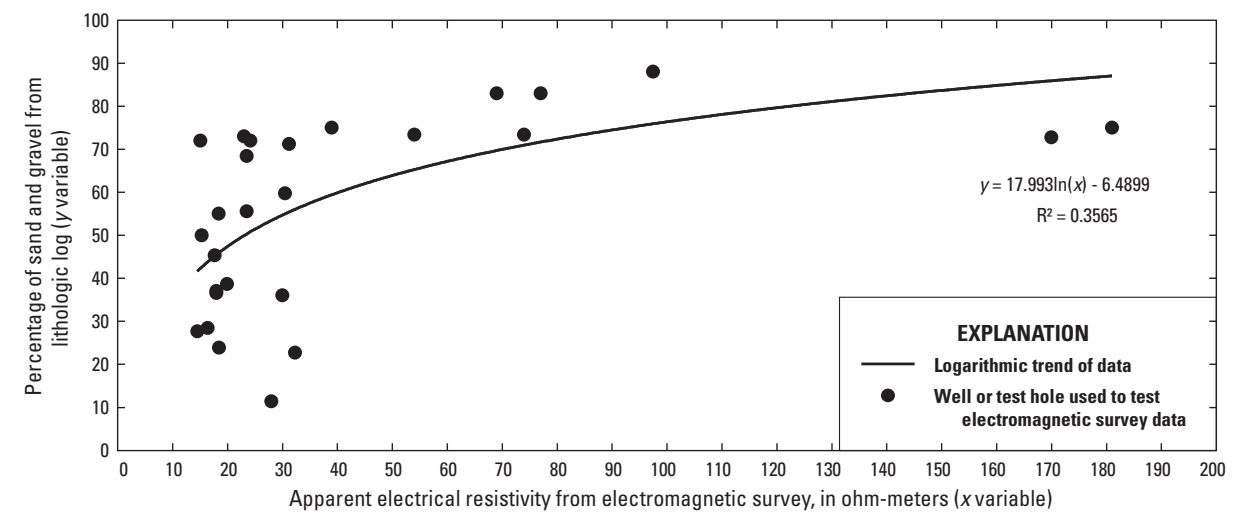

Figure S1-2. Relation between percentage of sand and gravel deposits and apparent electrical resistivity at a frequency of 13,590 hertz. 


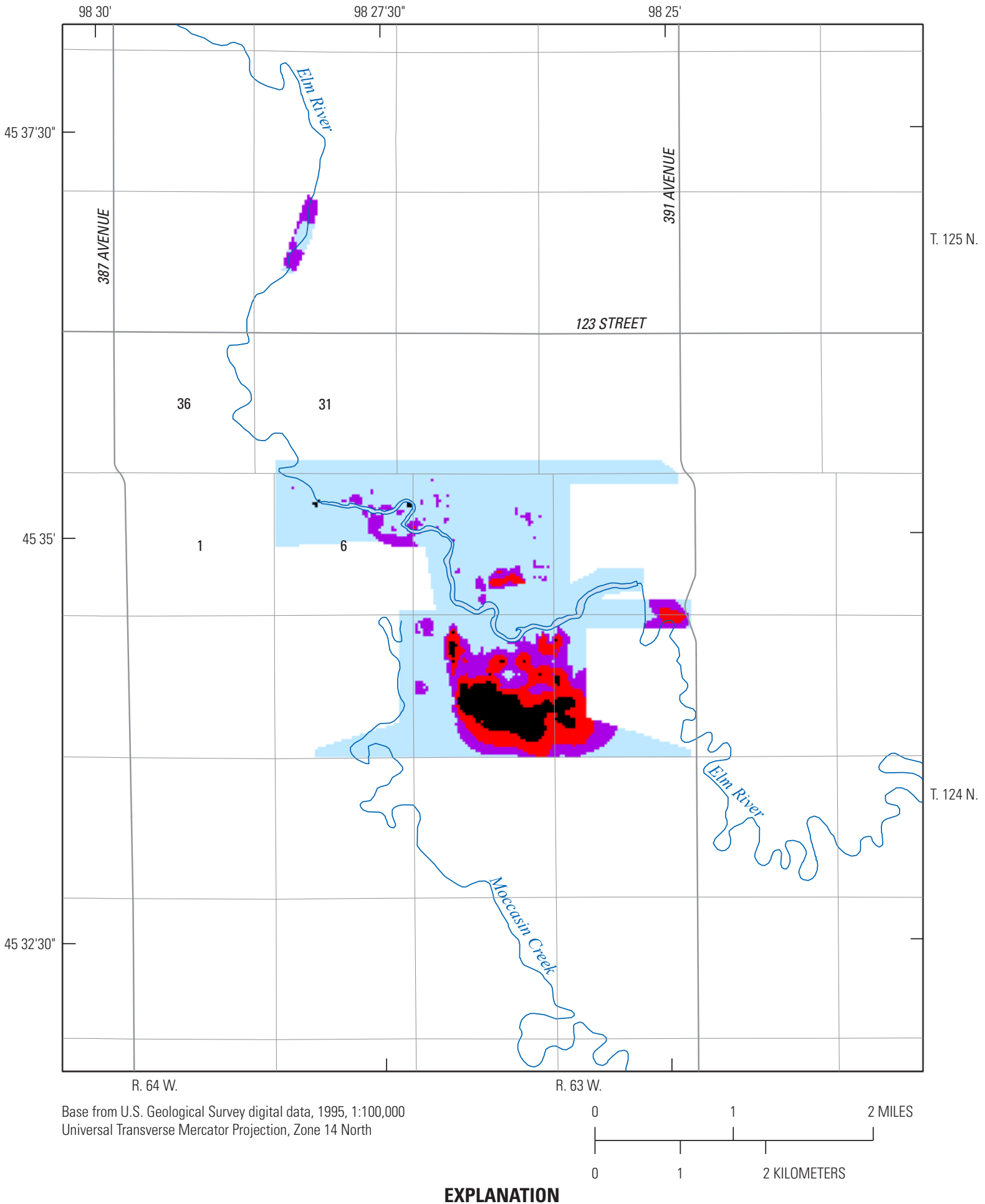

Resistivity, in ohm-meters

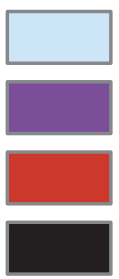

Less than 35

35 to less than 60

60 to less than 100

100 or greater

Figure S1-3. Apparent electrical resistivity distribution at a frequency of 13,590 hertz. 


\section{Supplement 2. Direct-Current Electrical Resistivity Geophysical Surveys}

Direct-current electrical resistivity surveys were conducted in the study area to determine the resistivity of the subsurface along the survey lines (fig. S2-1). The program RES2DINV was used to produce a two-dimensional model of the apparent resistivity of the subsurface through the inversion of the data points using the "smoothness-constrained leastsquares method" (Loke, 2010). Each profile was compared with the data from any lithologic logs (South Dakota Geological Survey, 2008) located near the profile (table S2-1) to correlate the apparent resistivity of the profile with the lithologic units likely to be present (technique described in Kress and others, 2006; Lucius and others, 2007).

Resistivity surveys are made by transmitting current into the subsurface through two current electrodes and measuring the resulting voltage between two potential electrodes. The resistance then is computed by dividing the measured voltage by the transmitted current. Resistivity is the resistance times the area divided by length. The equipment used to collect the resistivity data was a multi-channel earth resistivity meter with 56 electrode connections. A programmed series of resistivity measurements was made with a range in the combinations of current and potential electrode pairs and electrode spacing in specified arrangements (arrays). The dipole-dipole and inverse Schlumberger arrays used in the surveys are described in Loke (1999) and Zohdy and others (1974) along with the characteristics of the particular array and the theory for inverting the data to an apparent resistivity profile. The depth of the area represented by the resistivity measurement increases with increased electrode spacing. The dipole-dipole array has greater horizontal sensitivity than the inverse Schlumberger array and provided the best apparent resistivity profile when compared to nearby lithologic logs. The inverse Schlumberger array has more vertical sensitivity than the dipole-dipole array.

Survey 1 was conducted on November 17, 2008, from south to north just west of the boundary between sections 8 and 9 in T. 124 N., R. 63 W. (fig. S2-1). The electrode spacing was $26.25 \mathrm{ft}(8 \mathrm{~m})$ for a survey length of $1,076 \mathrm{ft}$, and the dipole-dipole array was used. Two wells, 124N63W08DAAD 1 and 124N63W08DAAD 2, are $150 \mathrm{ft}$ to the east of the profile and have lithologic logs available for comparison at $794 \mathrm{ft}$ and $692 \mathrm{ft}$, respectively, along the profile. These wells revealed interbedded sand, gravel, and clay with layer thicknesses between 1 and $13 \mathrm{ft}$, with a mean of $2 \mathrm{ft}$ and the thicker layers containing sand and gravel (South Dakota Geological Survey, 2008). The large electrode spacing prevented the detail of thin layers from appearing in the profile (fig. S2-2), but heterogeneity was identifiable throughout the profile. The top of the Elm aquifer was interpreted from the profile as at or near the land surface. The lower boundary of the sand and gravel layers appeared to be at a depth of about $70 \mathrm{ft}$ at the southern end of the profile and at a depth of about $100 \mathrm{ft}$ at the northern end. The apparent resistivity indicates the presence of the Middle James aquifer from $400 \mathrm{ft}$ along the profile to the end because the bottom of the sandy unit in the profile is at an altitude of about 1,210 ft. A confining clay layer between the Elm and Middle James aquifers might be present even though one is not indicated in the profile. High resistivity

Table S2-1. Station names and depths of lithologic logs that were compared with directcurrent electrical resistivity surveys.

[--, not applicable]

\begin{tabular}{clcc}
\hline $\begin{array}{c}\text { Survey identifier } \\
\text { (fig. S1-1) }\end{array}$ & Survey profile name(s) & Lithologic log station name & $\begin{array}{c}\text { Total depth of } \\
\text { lithologic log, } \\
\text { in feet }\end{array}$ \\
\hline 1 & ABER1DD & 124N63W08DAAD 1 & 107 \\
1 & ABER1DD & 124N63W08DAAD 2 & 47 \\
2 & ABER2DD, ABER2INS & 125N63W31CDAA & 56 \\
3 & ABER5DD, ABER5INS & 125N64W16DDDD & 116 \\
4 & ABER7DD, ABER7INS & -- & -- \\
5 & ABER8DD & -- & -- \\
6 & ABER9DD,ABER9INS & -- & -- \\
7 & A10DDTH3 & 124N63W04BBCB & 52 \\
8 & A10DD125_A_all & 124N63W08ABBA & 62 \\
8 & A10DD125_A_all & 124N63W05DDDD & 50 \\
9 & A10DDER1 & 124N63W08ABBA & 62 \\
9 & A10DDER1 & 124N63W08BAAA 1 & 121 \\
9 & A10DDER1 & 124N63W08ABBB & 52 \\
10 & A10DDER2 & 124N63W06ADBB & 54 \\
\hline
\end{tabular}




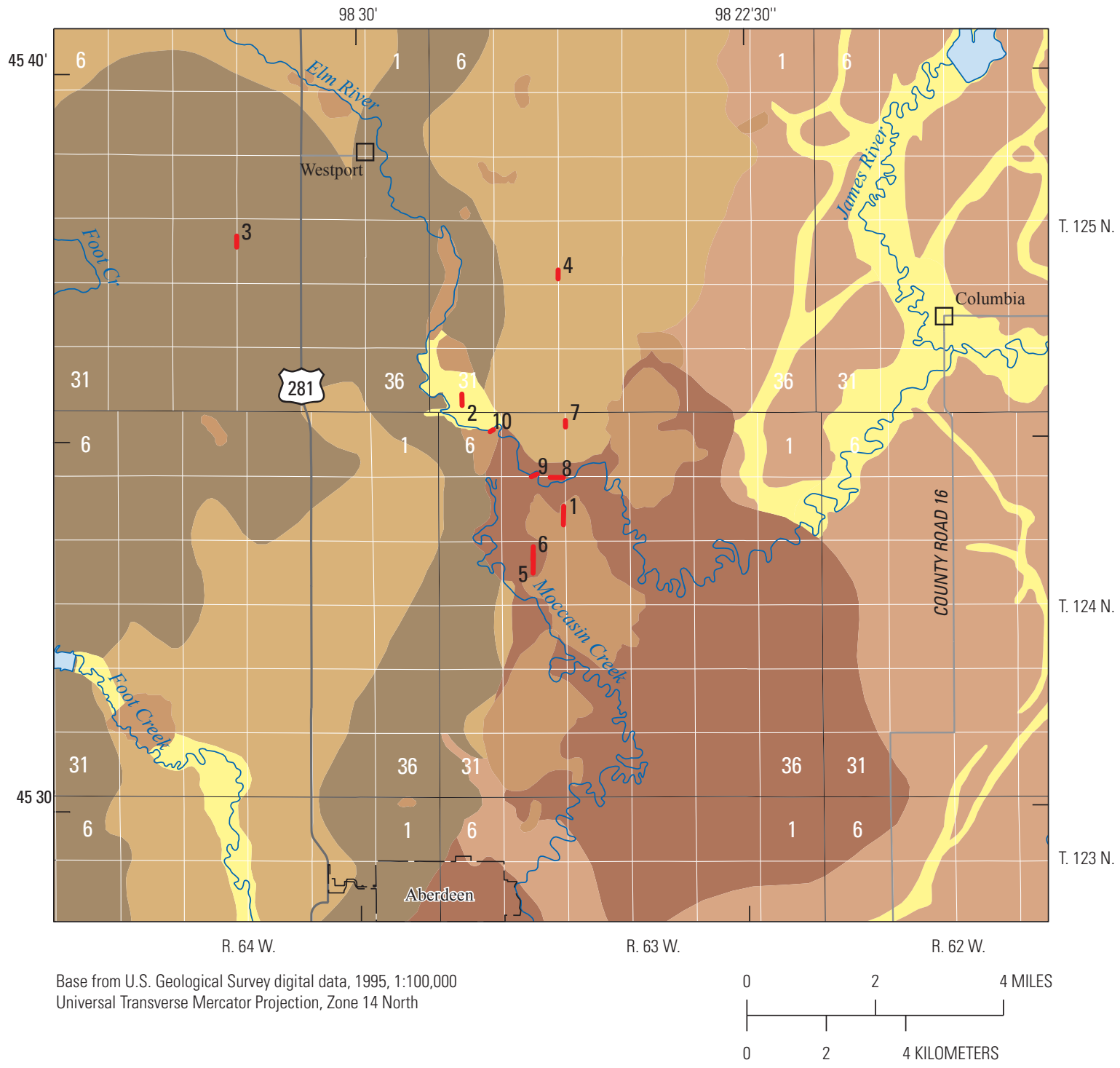

EXPLANATION

Glacial landforms (Leap, 1986)

Alluvium

Delta deposits

Ground moraine

Lacustrine silt and clay

Outwash sand and gravel

Recessional moraine

Direct-current geophysical surveys-Number is survey identifier

Figure S2-1. Location of direct-current electrical resistivity surveys and glacial landforms. 


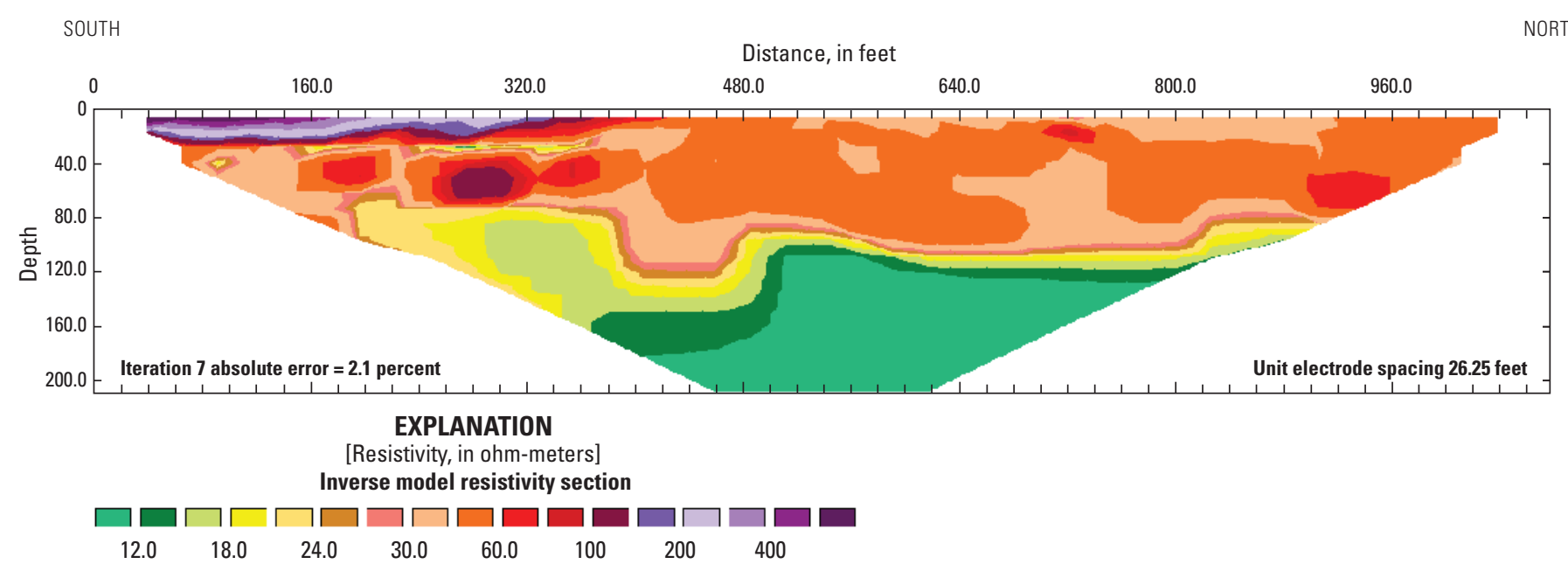

Figure S2-2. Resistivity profile for survey 1.

values at the surface from 0 to $300 \mathrm{ft}$ along the profile probably indicate unsaturated gravel because survey 1 overlies glacial outwash (fig. S2-1).

Surveys $2 \mathrm{a}$ and $2 \mathrm{~b}$ were conducted on November 18, 2008, one-quarter mile south of Pickus Pit (fig. 22) in section 31 of T. 125 N., R. 63 W. (fig. S2-1). The surveys were measured from south to north with an electrode spacing of $16.40 \mathrm{ft}$ (5 m) using the dipole-dipole (survey 2a; fig. S2-3A) and inverse Schlumberger (survey $2 \mathrm{~b}$; fig. S2-3B) arrays. Well $125 \mathrm{~N} 63 \mathrm{~W} 31 \mathrm{CDAA}$ lies on the survey line $515 \mathrm{ft}$ from the southern end, and the total survey length is $672 \mathrm{ft}$. The litho$\operatorname{logic} \log$ at this well indicates that the top and bottom of the Elm aquifer are at depths of 13 and $46 \mathrm{ft}$, respectively (South Dakota Geological Survey, 2008). The two data collection arrays produced slightly different profiles during inversion in RES2DINV. The inverse Schlumberger profile (fig. S2-3B) produced a consistent apparent resistivity value of about $40 \mathrm{ohm}-\mathrm{m}$ for the top and bottom of the Elm aquifer at depths that approximately matched the lithologic log. The dipoledipole profile must have an apparent resistivity of $24 \mathrm{ohm}-\mathrm{m}$ at the bottom of the aquifer and $40 \mathrm{ohm}-\mathrm{m}$ at the top if the profile is made to match the aquifer thickness as interpreted from the lithologic $\log$. Surveys $2 \mathrm{a}$ and $2 \mathrm{~b}$ were conducted in alluvium (fig. S2-1) where little overlying material exists, which agrees with the lithologic log and profiles.

Surveys $3 \mathrm{a}$ and $3 \mathrm{~b}$ were conducted on November 19, 2008, between sections 21 and 22 of T. 125 N., R. 64 W. (fig. S2-1). The electrode spacing was $16.40 \mathrm{ft}(5 \mathrm{~m})$, and the survey was done from south to north for $902 \mathrm{ft}$ with the dipole-dipole (survey 3a; fig. S2-4A) and inverse Schlumberger (survey $3 \mathrm{~b}$; fig. S2-4B) arrays. The northern end of the survey was about 0.3 mi south of well 125N64W16DDDD. The profile indicates that the top of the Elm aquifer is at or near the land surface because the highest resistivities (18-27 ohm-m) exist there. The underlying shale was estimated to be at a depth of about $80 \mathrm{ft}$, with an apparent resistivity of less than 8 plus or minus 2 ohm-m. At well 125N64W16DDDD, the top of the shale is $82 \mathrm{ft}$ below the land surface according to the lithologic log (South Dakota Geological Survey, 2008). The lithologic log indicated upper and lower sand units with thicknesses of 18 and $15 \mathrm{ft}$, respectively (South Dakota Geological Survey, 2008). The sand units were separated by $37 \mathrm{ft}$ of clay (South Dakota Geological Survey, 2008). The sand units appear to have merged in the area of the survey, but the profile is not sufficiently detailed to give certainty. The dipole-dipole profile (fig. S2-4A) indicates horizontal discontinuity within the Elm aquifer, particularly between about 220 and $300 \mathrm{ft}$ along the survey line. The inverse Schlumberger profile (fig. S2-4B) places the discontinuity between 160 and $280 \mathrm{ft}$ along the survey line. The degree of connection between the sandy units to the north and south of the discontinuity cannot be readily determined from the profile alone. The resistivity of the part of the profile interpreted as the Elm aquifer seems to be greater than about $18 \mathrm{ohm}-\mathrm{m}$. The relatively low value interpreted for the boundary of the Elm aquifer is caused by high clay content, which corresponds well with the landform that was mapped by Leap (1986) as a recessional moraine (fig. S2-1).

Surveys $4 \mathrm{a}$ and $4 \mathrm{~b}$ were conducted on November 19, 2008, about $30 \mathrm{ft}$ west of the boundary between section 20 and 21 of T. 125 N., R. 63 W. (fig. S2-1). The surveys were done from south to north with an electrode spacing of $13.12 \mathrm{ft}(4$ $\mathrm{m}$ ) for $722 \mathrm{ft}$ using the dipole-dipole (survey 4a; fig. S2-5A) and inverse Schlumberger (survey $4 \mathrm{~b}$; fig. S2-5B) arrays. The resistivity profiles indicate that the top of the Elm aquifer is at a depth of about $25 \mathrm{ft}$ and the bottom of the aquifer is at a depth of about 110 to $130 \mathrm{ft}$. The apparent resistivity of the top of the aquifer is about 16.5 to $21 \mathrm{ohm}-\mathrm{m}$, with differences in the dipole-dipole and inverse Schlumberger profiles increasing the uncertainty of the model interpretation. The maximum apparent resistivity within the profiles was about $25 \mathrm{ohm}-\mathrm{m}$, so the apparent uniformity of the aquifer in the inverse Schlumberger profile (fig. S2-5B) may be from the smoothing of interbedded sand and clay. The heterogeneous layer above the Elm aquifer is consistent with till because the survey location is within the ground moraine (fig. S2-1). 

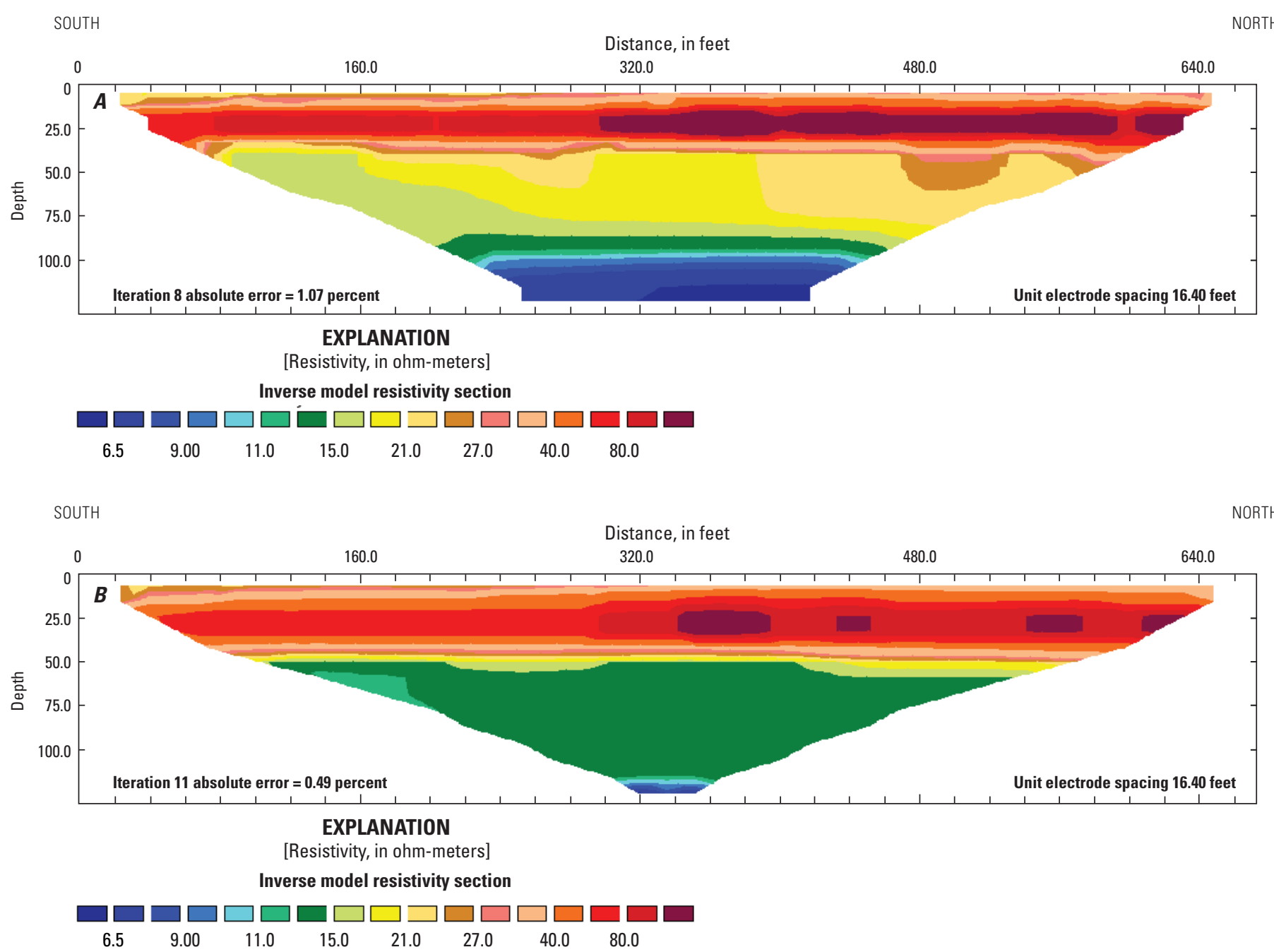

Figure S2-3. Resistivity profiles for survey 2. A, Dipole-dipole profile, and B, inverse Schlumberger profile.

Survey 5 was conducted on November 20, 2008, in the northwestern quarter of section 17 of T. 124 N., R. $63 \mathrm{~W}$. (fig. S2-1). The survey was conducted from south to north as a roll-along survey totaling $1,082 \mathrm{ft}$ with an electrode-spacing of $19.68 \mathrm{ft}(6 \mathrm{~m})$ and the dipole-dipole array. In a roll-along survey, the first 28 of the 56 electrodes are picked up and attached to the end the survey line, and the collection of the data continues to create a continuous profile of the desired length. The Elm aquifer top seems to be at the land surface near the middle of the profile (fig. S2-6) and at depths of about 20 to $30 \mathrm{ft}$ near the edges. The Elm aquifer probably includes clay in the area; however, the resistivity of the 60- to 80 - $\mathrm{ft}$ thick aquifer layer is greater than $24 \mathrm{ohm}-\mathrm{m}$, indicating more sand and gravel than in other surveyed areas. Some sand and gravel likely are present below a depth of about $120 \mathrm{ft}$ because the apparent resistivity is 15 to $21 \mathrm{ohm}-\mathrm{m}$. Survey 5 is within the delta deposits mapped by Leap (1986) (fig. S2-1).

Surveys $6 \mathrm{a}$ and $6 \mathrm{~b}$ were conducted on November 20, 2008, in the northwestern quarter of section 17, T. 124 N., R. $63 \mathrm{~W}$. and overlapped the northern end of survey 5 (fig. S2-1). The surveys were conducted from south to north with an electrode spacing of $19.68 \mathrm{ft}(6 \mathrm{~m})$ for 1,082 $\mathrm{ft}$ using the dipole-dipole (survey 6a; fig. S2-7A) and inverse Schlumberger (survey 6 b; fig. S2-7B) arrays. The top of the Elm aquifer seems to be at depths of less than $20 \mathrm{ft}$ and at the land surface in some places. The thickness of the Elm aquifer is about 45 to 90 $\mathrm{ft}$ with the variability caused, in part, by limited contrast in apparent resistivity. The apparent resistivity from about 90 to $120 \mathrm{ft}$ deep ranges from 8.5 to $21 \mathrm{ohm}-\mathrm{m}$. The slow transition from the Elm aquifer above a depth of $90 \mathrm{ft}$ to the clay below a depth of about $130 \mathrm{ft}$ might indicate that a small layer of the Middle James aquifer is present in the area. The resolution of the data lowers with depth, so the profile cannot provide definitive evidence of the presence of a thin sand unit. Similar to survey 5 , surveys $6 \mathrm{a}$ and $6 \mathrm{~b}$ are in the delta deposits (fig. S2-1).

Survey 7 was conducted on June 1, 2010, about $25 \mathrm{ft}$ east of the boundary between sections 4 and 5 of T. $124 \mathrm{~N}$., R. 63 W. (fig. S2-1). The survey was conducted from south to north with an electrode spacing of $9.84 \mathrm{ft}(3 \mathrm{~m})$, total length of $541.2 \mathrm{ft}$, and the dipole-dipole array. Well 124N63W04BBCB lies about $220 \mathrm{ft}$ from the southern end of the survey. The 

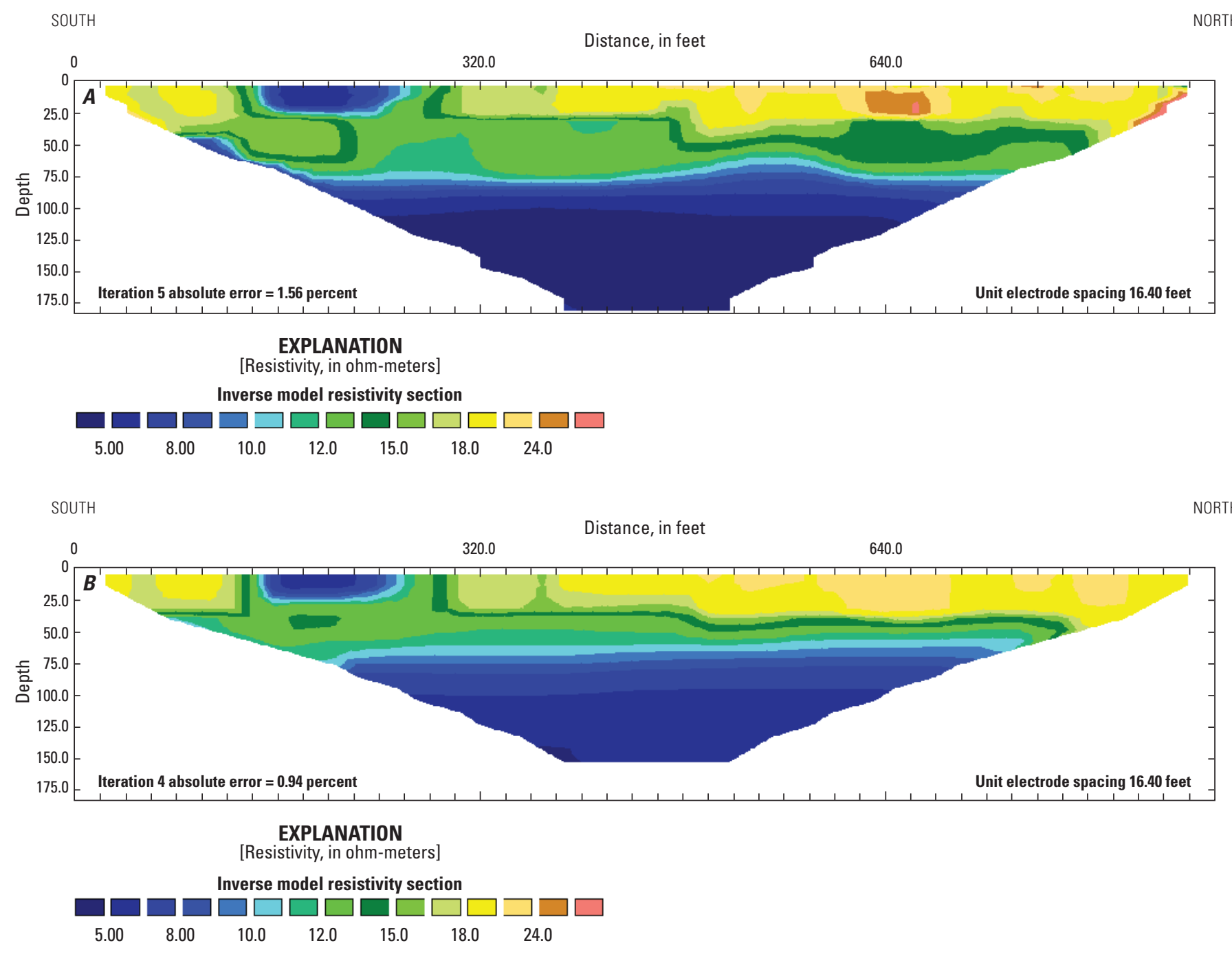

Figure S2-4. Resistivity profiles for survey 3. A, Dipole-dipole profile, and B, inverse Schlumberger profile.

lithologic log indicated interbedded sand and gravel with clay from 10 to $40 \mathrm{ft}$ deep and clay with gravel from 40 to $52 \mathrm{ft}$ deep (South Dakota Geological Survey, 2008). The well was drilled only to a depth of $52 \mathrm{ft}$ (South Dakota Geological Survey, 2008), whereas the profile (fig. S2-8) shows $120 \mathrm{ft}$; therefore, the comparison between the lithologic log and the resistivity profile is limited. The profile has an average apparent resistivity of $13.5-15 \mathrm{ohm}-\mathrm{m}$ from 0-30 ft deep and of 21-24 ohm-m from 30-75 ft deep. This profile demonstrates the limitation of apparent resistivity data in characterizing the heterogeneous layering that commonly exists in glacial deposits. The location of survey 7 was in ground moraine (fig. S2-1).

Surveys A10DD125 and A10DD125A were conducted on June 3,2010 , in section 8 of T. 124 N, R. $63 \mathrm{~W}$. The surveys were carried out from east to west, with an electrode spacing of $6.56 \mathrm{ft}(2 \mathrm{~m})$ with the dipole-dipole array. These were roll-along surveys and the first movement of the electrodes was incorrectly conducted in survey A10DD125. The survey was begun again at this point (A10DD125A) and the datasets were combined. The usable data from the two surveys were combined to form one profile, survey 8 (fig. S2-9), with a total length of 1,082 ft, by using the concatenation function in RES2DINV (Loke, 2010) because 28 of the electrodes from each survey were identical. Well 124N63W08ABBA is $752 \mathrm{ft}$ to the east of the western end of the concatenated profile. Well 124N63W05DDDD is located $245 \mathrm{ft}$ north-northeast of the eastern end of the profile. The lithologic data from both wells indicate that the top of the Elm aquifer is about $10 \mathrm{ft}$ below the land surface, and the bottom of the aquifer is at a depth of 44 to $56 \mathrm{ft}$ (South Dakota Geological Survey, 2008). To match these data exactly, the apparent resistivity values of the top and bottom of the Elm aquifer would be about 15 and $25 \mathrm{ohm}-\mathrm{m}$, respectively. Based on the profile, the top of the Elm aquifer seems to be at a depth of about $20 \mathrm{ft}$ and the thickness varies from potentially as little as $20 \mathrm{ft}$ to about $40 \mathrm{ft}$. The possible thinning of the aquifer near the center of the profile indicates the presence of more clay near the center than closer to the edges of the profile. The apparent resistivity range of 21 to $24 \mathrm{ohm}-\mathrm{m}$ where the aquifer might be thinner indicates that sand is still present. The entire length of survey 8 was located in delta deposits (fig. S2-1). 


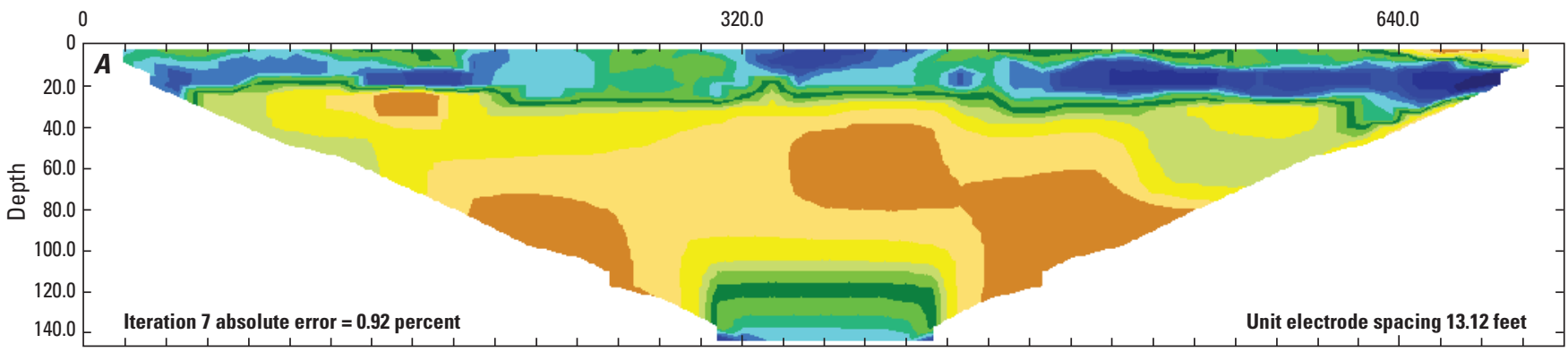

\section{EXPLANATION}

[Resistivity, in ohm-meters]

Inverse model resistivity section
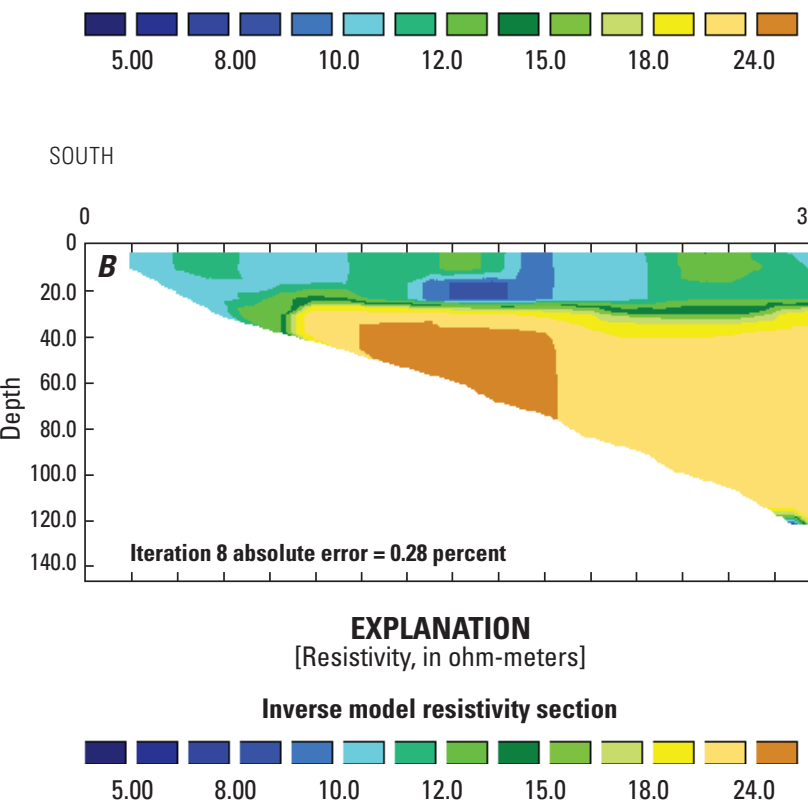

Figure S2-5. Resistivity profile for survey 4. A, Dipole-dipole profile, and $B$, inverse Schlumberger profile.

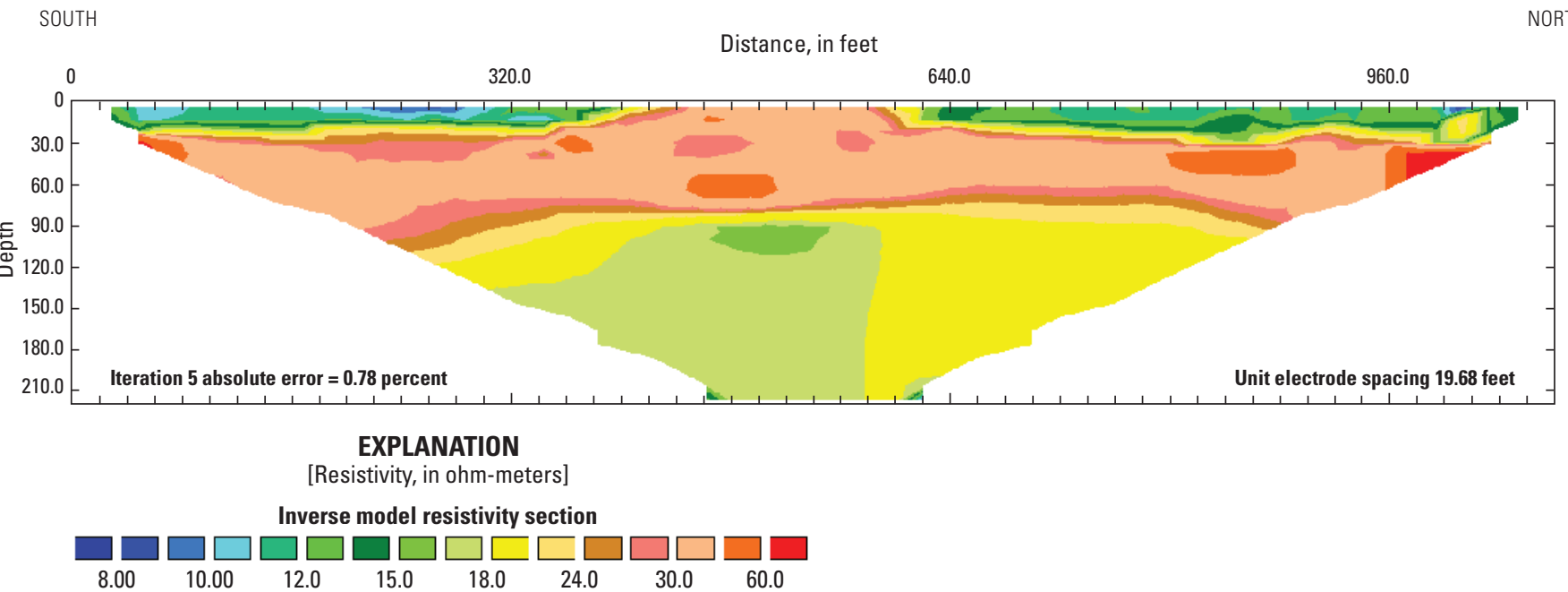

Figure S2-6. Resistivity profile for survey 5. 
SOUTH

Distance, in feet

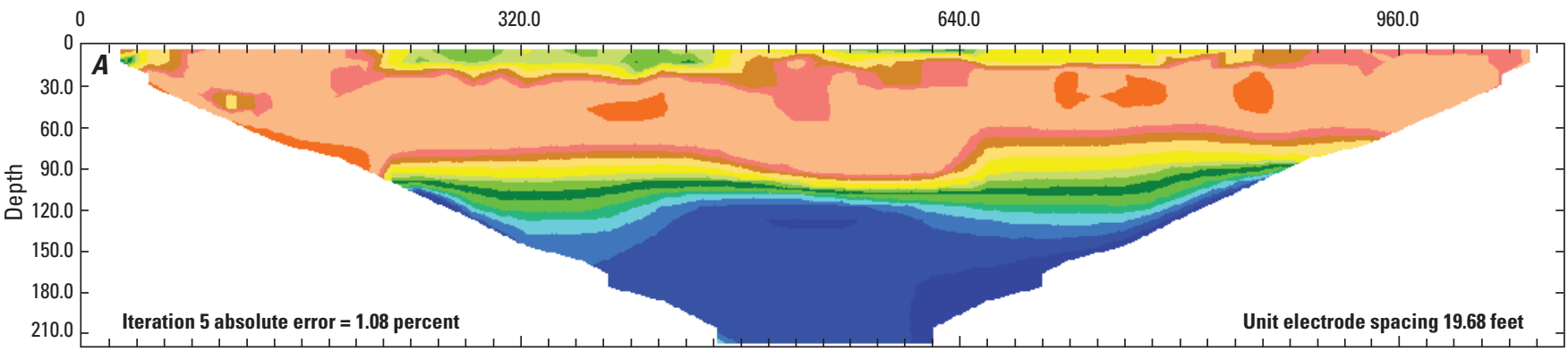

EXPLANATION

[Resistivity, in ohm-meters]

Inverse model resistivity section

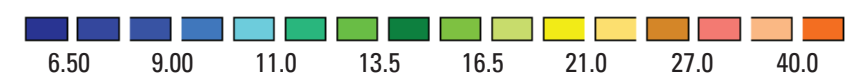

SOUTH

Distance, in feet

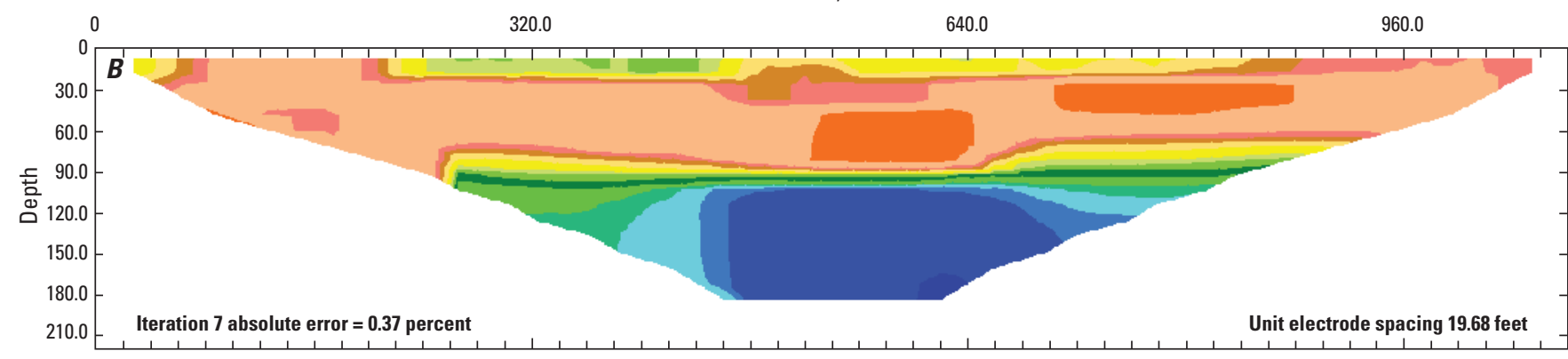

EXPLANATION

[Resistivity, in ohm-meters]

Inverse model resistivity section

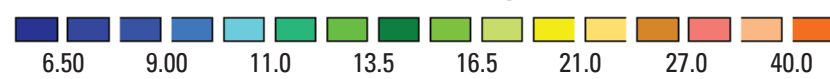

Figure S2-7. Resistivity profiles for survey 6. $A$, Dipole-dipole profile, and $B$, inverse Schlumberger profile.

SOUTH

Distance, in feet

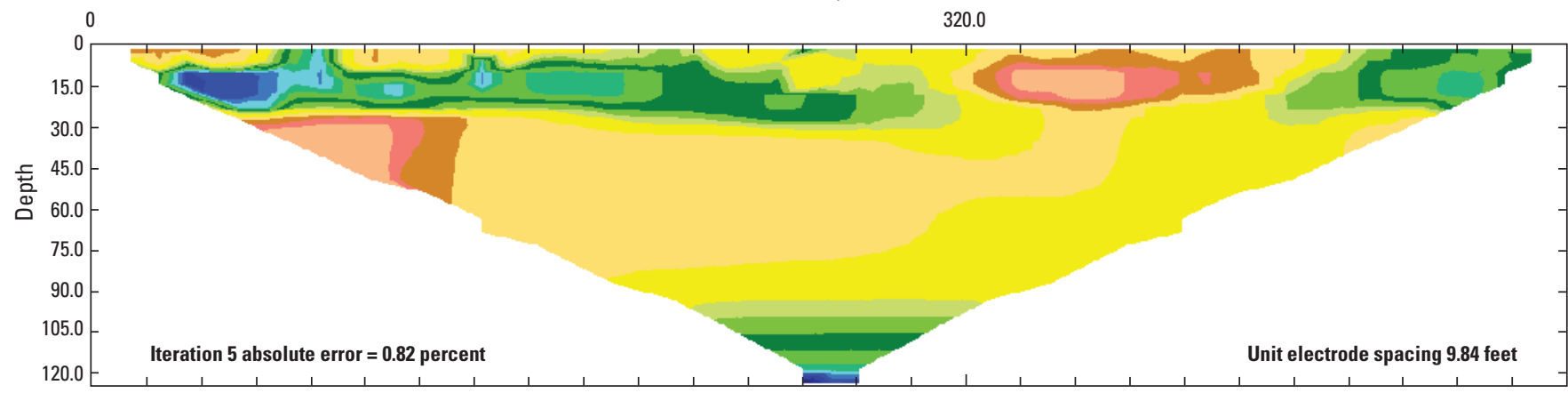

EXPLANATION

[Resistivity, in ohm-meters]

Inverse model resistivity section

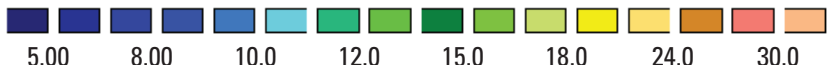

Figure S2-8. Resistivity profile for survey 7. 


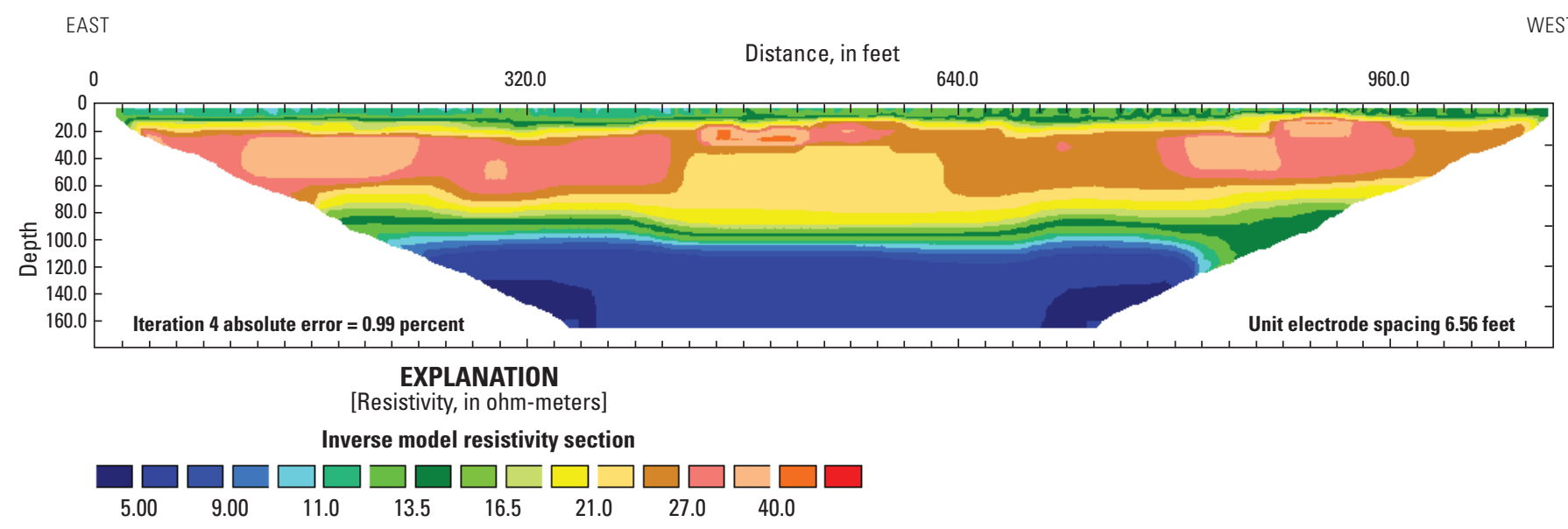

Figure S2-9. Resistivity profile for survey 8.

Survey 9 was completed on June 2, 2010, on the southern side of the Elm River in section 5 of T. 124 N., R. 63 W. (fig. S2-1). The survey was conducted from northeast to southwest. The survey used an electrode spacing of $9.84 \mathrm{ft}$ $(3 \mathrm{~m})$ over a length of $541 \mathrm{ft}$ and the dipole-dipole array. Well 124N63W08ABBA is $415 \mathrm{ft}$ to the southeast of the eastern end of the profile and across the Elm River. Well 124N63W08BAAA 1 is $226 \mathrm{ft}$ to the southeast of the western end of the profile (fig. S2-10). Well 124N63W08ABBB is $345 \mathrm{ft}$ to the west-southwest of the western end of the profile, but not quite on the same line as the survey. The primary difference between the three lithologic logs was that the top of the aquifer was closest to the surface at well 124N63W08ABBA at a depth of $10 \mathrm{ft}$ and the aquifer was $46 \mathrm{ft}$ thick (South Dakota Geological Survey, 2008). The other two lithologic logs indicated that the uppermost sand intervals were at depths of 23 $\mathrm{ft}$ and $29 \mathrm{ft}$, with the bottom of the aquifer at a depth of $45 \mathrm{ft}$ (South Dakota Geological Survey, 2008). All three lithologic logs indicated interbedded clay with the sand (South Dakota Geological Survey, 2008). The top of the Elm aquifer was interpreted to be about 15 to $20 \mathrm{ft}$ deep in the profile, with an apparent resistivity of 24 to $27 \mathrm{ohm}-\mathrm{m}$ at the top of the aquifer. The minimum aquifer thickness in the profile was about $20 \mathrm{ft}$. Survey 9 is in the delta deposits (fig. S2-1).

Survey 10 was completed on June 2, 2010, on the southern side of the Elm River in the northeast quarter of section 6 of T. 124 N., R. 63 W. (fig. S2-1). The survey was conducted from the northeast to the southwest, with an electrode spacing of $6.56 \mathrm{ft}(2 \mathrm{~m})$ and with only 42 electrodes. Survey 10 was $269 \mathrm{ft}$ long (fig. S2-11) and was truncated at the Eyestone Pit (fig. 22). Well 124N63W06ADBB was $58 \mathrm{ft}$ to the northnorthwest of the southwestern end of the survey. The profile indicated that the top of the Elm aquifer was at a depth of 20 to $35 \mathrm{ft}$. According to the lithologic log, the top of the Elm aquifer was at $19 \mathrm{ft}$ and the aquifer thickness was $30 \mathrm{ft}$ (South Dakota Geological Survey, 2008). The lithologic log indicated sand in the upper $15 \mathrm{ft}$ and gravel in the lower $15 \mathrm{ft}$ of the Elm aquifer (South Dakota Geological Survey, 2008). The apparent resistivity at the top of the Elm aquifer was about 24 to $30 \mathrm{ohm}-\mathrm{m}$ for a depth of about $20 \mathrm{ft}$. The profile indicated that the bottom of the Elm aquifer was lower than indicated by the lithologic $\log$. Based on the resistivity profile, the bottom of the Elm aquifer seems to be at about $55 \mathrm{ft}$ to $60 \mathrm{ft}$ below the land surface. Survey 10 was in glacial outwash (fig. S2-1), which is reasonable for the thickness of the sand and gravel layers and the presence of the Eyestone Pit.

From the comparison to lithologic logs, the direct-current resistivity profiles gave approximate depths and thicknesses for the Elm aquifer, but did not provide sufficient detail to identify clay interbeds or an exact depth for the top and bottom of the aquifer. The Elm aquifer seems to have resistivity values greater than $30 \mathrm{ohm}-\mathrm{m}$ when sand and gravel are the predominant sediments. When sand is interbedded with layers of clay, the resistivity values in the Elm aquifer are lowered to values greater than $18 \mathrm{ohm}-\mathrm{m}$ and possibly as low as $15 \mathrm{ohm}-\mathrm{m}$. The resistivity of the interbeds was collected as an average, partly because the electrode spacing used was $6.56 \mathrm{ft}(2 \mathrm{~m})$ or larger, whereas the interbeds commonly were 1 to $6 \mathrm{ft}$ thick. The Middle James aquifer might have been present at some of the survey locations; however, the thickness of the unit was difficult to determine because the resolution of the profiles decreased with depth. The resistivity values within any profile are quite variable and the different profiles demonstrate the spatial variability of the glacial aquifer thickness. 
NORTHEAST

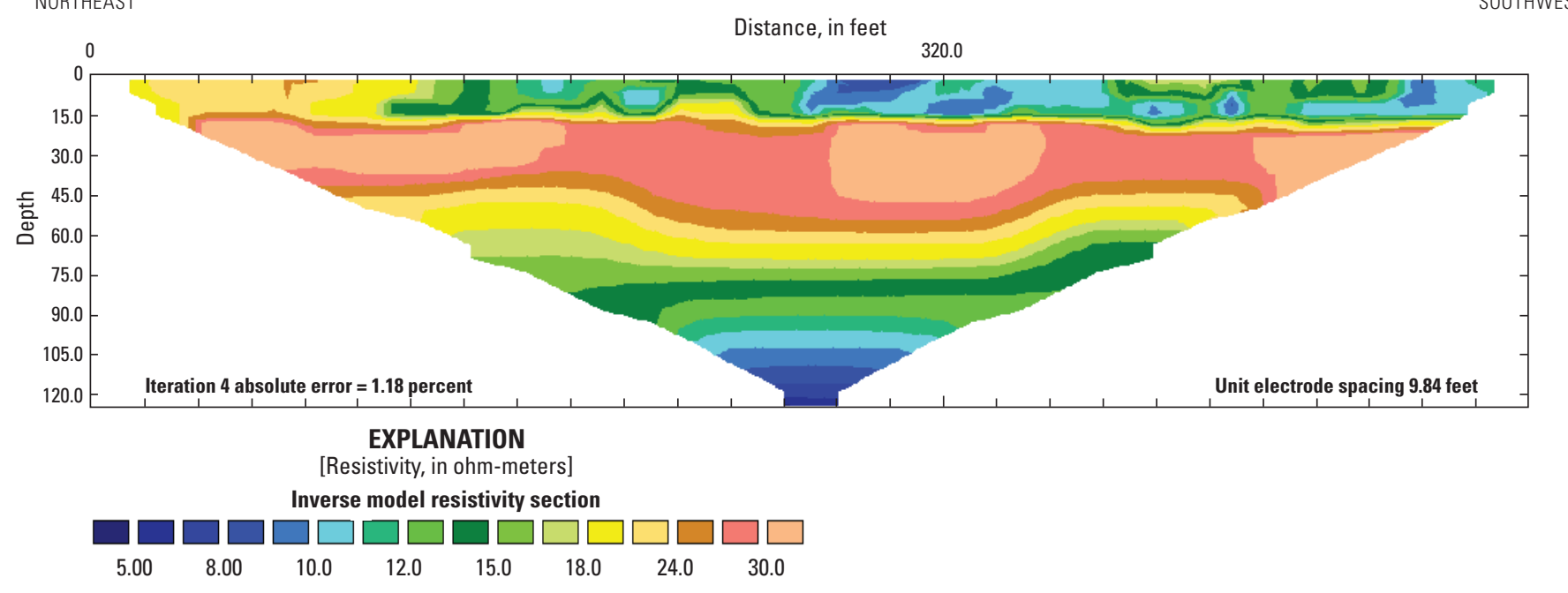

Figure S2-10. Resistivity profile for survey 9.

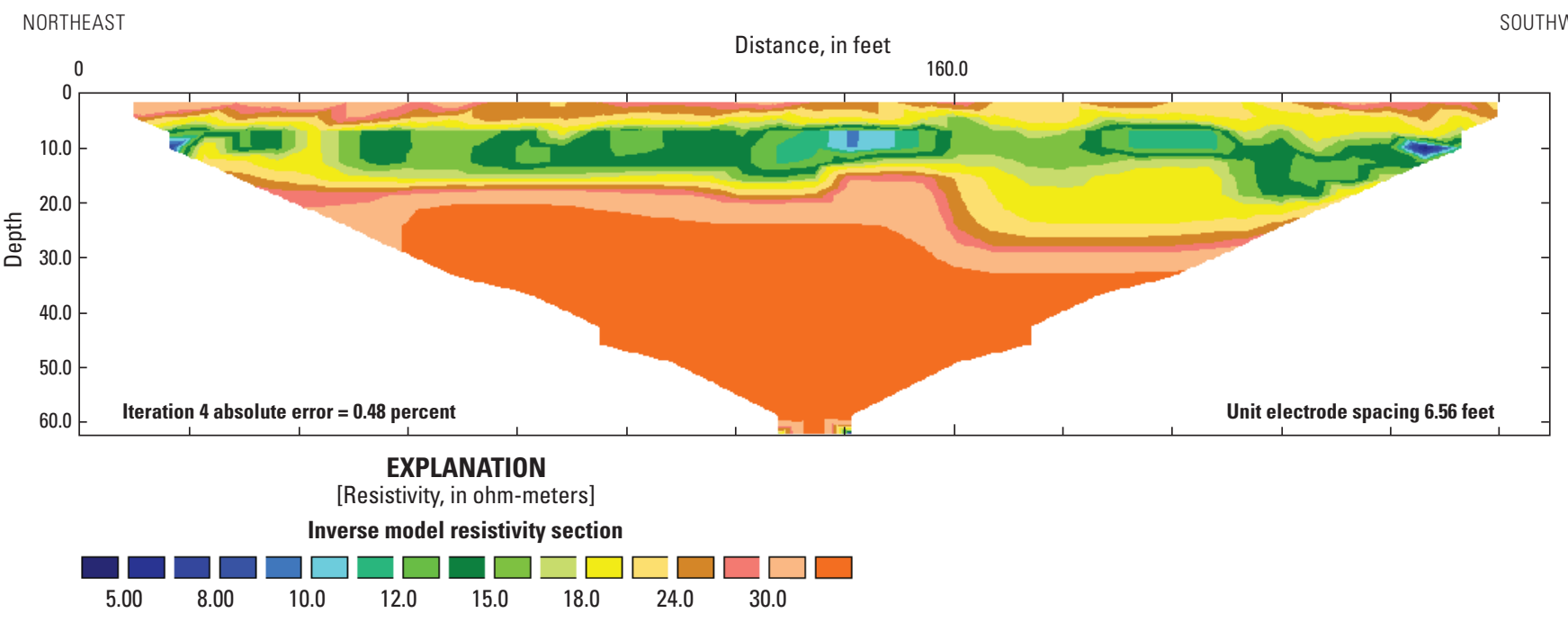

Figure S2-11. Resistivity profile for survey 10. 


\section{Supplement 3. Aquifer Test of Elm Aquifer at Eyestone Pit}

An aquifer test of the Elm aquifer was conducted from September 14 to 21, 2009, by pumping a well at Eyestone Pit for 6.625 days and measuring drawdown in observation wells PZ2, PZ3, and PZ5, and the water level of Eyestone Pit at observation well Pit1 (fig. S3-1). The pumping well discharged water at a rate of 1.547 cubic feet per second $\left(\mathrm{ft}^{3} / \mathrm{s}\right)$ for the first 3.625 days, and then the pumping rate was increased to $3.095 \mathrm{ft}^{3} / \mathrm{s}$ for the remainder of the aquifer test. Discharged water was removed from the site and not allowed to spill onto the land surface.

A numerical model was constructed to simulate the aquifer test and calculate hydraulic properties by using MODFLOW-2005 (Harbaugh, 2005) and the principle of superposition. The principle of superposition states that solutions to individual components of a linear problem can be added to solve composite problems (Reilly and others, 1987); therefore, the aquifer test could be simulated in terms of hydraulic head change rather than the actual values. Initial conditions were simulated as zero change, representing no drawdown and a uniform starting hydraulic head. The static water level in the three observation wells ranged from 7 to $9 \mathrm{ft}$ above the top of the aquifer. The aquifer was assumed to be confined throughout the aquifer test analysis area; therefore, the assumption of linearity was valid.

The model was composed of one layer, the Elm aquifer, which was assumed to be underlain by impermeable sediments in the aquifer test analysis area. The aquifer test analysis area (fig. S3-1, fig. 22) consisted of 150 rows and 150 columns, all of which were $33.33 \mathrm{ft}(10.16 \mathrm{~m})$ wide. The grid was extended to a total of 395 rows oriented east to west and 356 columns oriented north to south, with cell sizes increasing at a ratio of 1.3 or less toward the boundary of the model area from the central aquifer test analysis area. This extended the boundaries of the model area 134 miles from the $5,000 \mathrm{ft}$ by $5,000 \mathrm{ft}$ aquifer test analysis area to minimize the effects of the boundaries on analysis of hydraulic properties. The cells bounding the grid were simulated as constant head cells. The inflow from the constant head cells in the simulation was small, less than $5.0 \times 10^{-6} \mathrm{ft}^{3} / \mathrm{s}$.

A uniform thickness of $30 \mathrm{ft}$ for the Elm aquifer was assumed on the basis of the average thickness of the aquifer determined from lithologic logs in the aquifer test analysis area. The starting hydraulic head was assumed to be $6 \mathrm{ft}$ above the top of the aquifer on the basis of the average of hydraulic head values throughout the aquifer test analysis area. The hydraulically connected Elm River was assumed to have a head equal to the starting hydraulic head of the aquifer and a bottom altitude $7 \mathrm{ft}$ below the head on the basis of the average depth of the Elm River in the aquifer test analysis area.

The cells representing the Eyestone and Jacob Pits were assigned a high hydraulic conductivity of $8.78 \times 10^{6} \mathrm{ft} / \mathrm{d}$ and a storage coefficient of 0.99 to approximate the hydraulic properties of the pit area. The horizontal hydraulic conductivity of the Elm aquifer, the confined storage coefficient of the Elm aquifer, and the riverbed conductance were the independent variable parameters estimated by the numerical modeling process.

The model simulated pumping from the well at Eyestone Pit in transient state with 14 stress periods each about 0.5 day in length (table S3-1). The pumping well discharged at $1.547 \mathrm{ft}^{3} / \mathrm{s}$ for the first 3.625 days (stress periods $1-7$ ), and then the pumping rate was increased to $3.095 \mathrm{ft}^{3} / \mathrm{s}$ for the next 3 days of the aquifer test (stress periods 8-13). Stress period 14 in the 7-day simulation represented 0.375 days after pumping was ended. The purpose of this stress period was to allow calibration to some measurements that were made shortly after the pumping ceased.

Table S3-1. Pumping rate and time for each stress period.

[ft $\mathrm{ft}^{3} / \mathrm{s}$, cubic feet per second]

\begin{tabular}{ccc}
\hline Stress period & $\begin{array}{c}\text { Stress period length } \\
\text { (days) }\end{array}$ & $\begin{array}{c}\text { Pumping rate } \\
\text { (ft } \mathbf{3} \text { ) }\end{array}$ \\
\hline 1 & 0.500 & 1.547 \\
2 & 0.500 & 1.547 \\
3 & 0.500 & 1.547 \\
4 & 0.500 & 1.547 \\
5 & 0.500 & 1.547 \\
6 & 0.500 & 1.547 \\
7 & 0.625 & 1.547 \\
8 & 0.375 & 3.095 \\
9 & 0.500 & 3.095 \\
10 & 0.500 & 3.095 \\
11 & 0.500 & 3.095 \\
12 & 0.500 & 3.095 \\
13 & 0.625 & 3.095 \\
14 & 0.375 & 0.00 \\
\hline
\end{tabular}




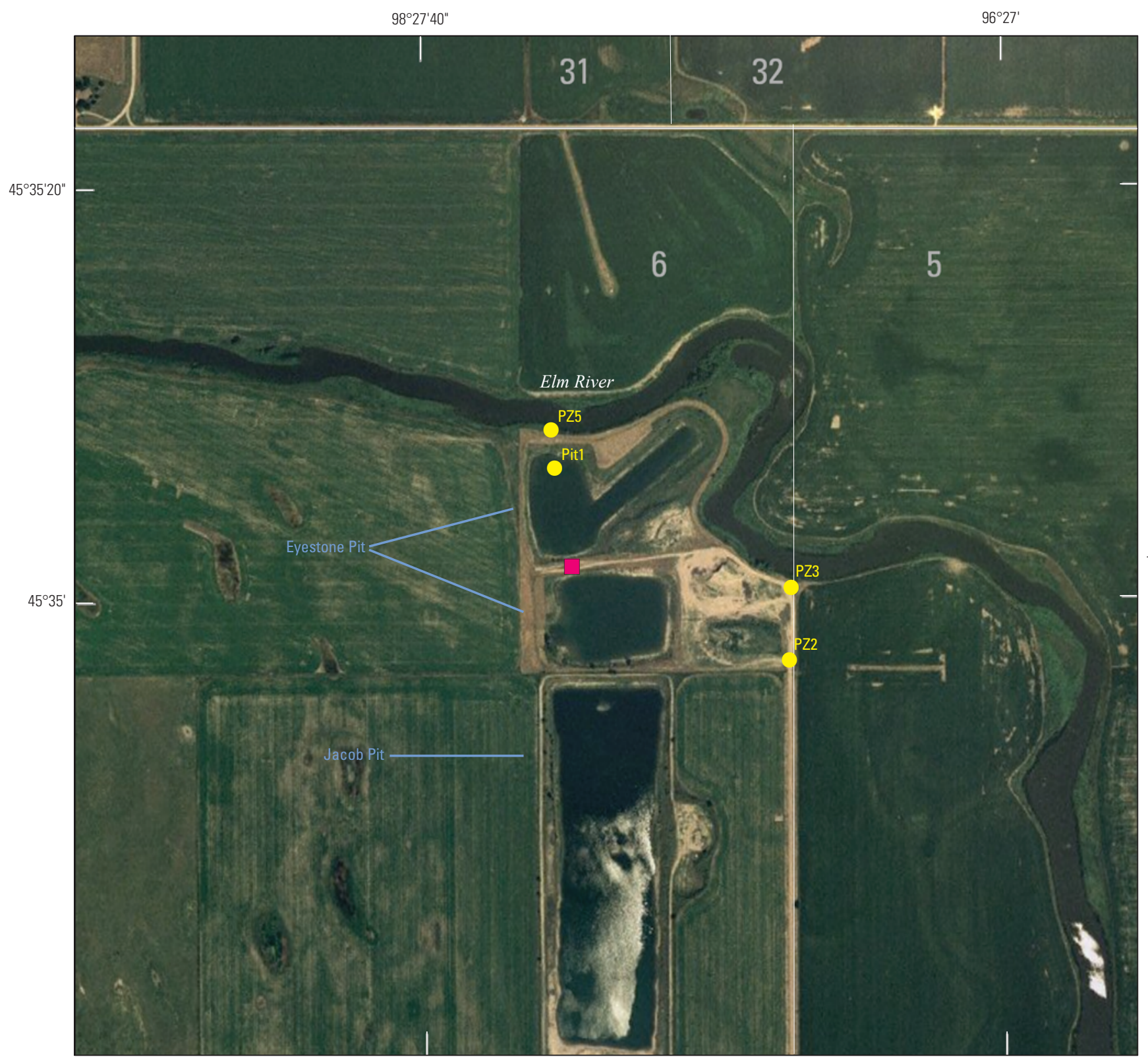

Base from U.S. Geological Survey digital data, 1995, 1:100,000 Universal Transverse Mercator Projection, Zone 14 North

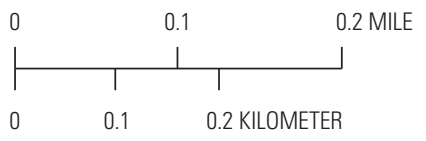

\section{EXPLANATION}

Observation wells with site identifier

Pumping well

Figure S3-1. Location of Eyestone Pit, pumping well, and observation wells for Eyestone Pit aquifer test. 


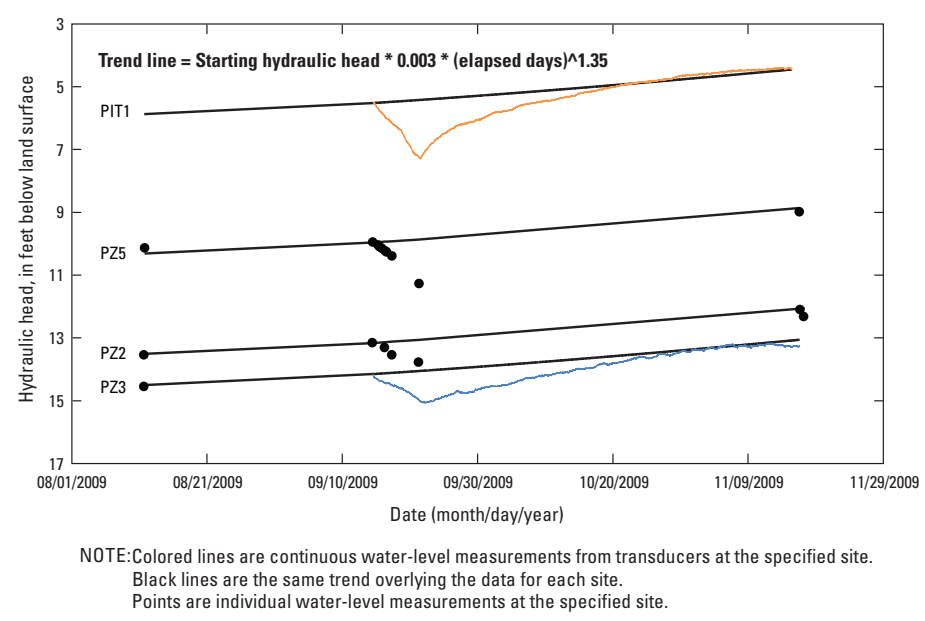

Figure S3-2. Comparing hydraulic head for observation wells Pit1, $\mathrm{PZ2}, \mathrm{PZ3}$, and PZ5, and trends in hydraulic head.

The hydraulic head at the observation wells was monitored before and after the tests to estimate trends in hydraulic heads that existed during the aquifer test (fig. S3-2). The same trend in hydraulic head was evident at all four observation wells. The hydraulic head estimated from the trend line rose about 0.1 foot during the aquifer test. The observed drawdown was calculated by subtracting the measured hydraulic head from the trend line values (table S3-2).

The simulated drawdown for the four observation wells was then optimized to determine the best fit to the observed drawdown by using the parameter estimation software Parameter ESTimation code (PEST) (Doherty, 2005). PEST uses nonlinear estimation techniques as described by Levenberg (1944), Marquardt (1963), and Doherty (2005) to iteratively estimate parameters. New parameter values were calculated until the residuals, or differences between the observed and simulated drawdown, were minimized.

The parameter estimation process resulted in small residuals between the observed and simulated drawdown values (table S3-2). Linear regression between the 36 observed and simulated drawdown values had a coefficient of determination $\left(\mathrm{R}^{2}\right.$ value) of 0.98 with an average arithmetic difference of $-0.02 \mathrm{ft}$ and an average absolute difference of $0.05 \mathrm{ft}$. The calculated hydraulic properties were $418 \mathrm{ft} / \mathrm{d}$ for hydraulic conductivity, $2.4 \times 10^{-5}$ for confined storage coefficient, and $46 \mathrm{ft}^{2} / \mathrm{d}$ for riverbed conductance. The rate of induced flow from the Elm River during the last pumping stress period was $0.46 \mathrm{ft}^{3} / \mathrm{s}$.
Table S3-2. Observed and simulated drawdown for the Eyestone Pit aquifer test.

\begin{tabular}{|c|c|c|}
\hline \multirow{2}{*}{$\begin{array}{l}\text { Elapsed time since } \\
\text { start of pumping } \\
\text { (days) }\end{array}$} & \multicolumn{2}{|c|}{ Drawdown (feet) } \\
\hline & Observed & Simulated \\
\hline \multicolumn{3}{|c|}{ Observation well Pit1 } \\
\hline 0.50 & 0.14 & 0.14 \\
\hline 1.00 & 0.28 & 0.26 \\
\hline 1.50 & 0.39 & 0.37 \\
\hline 2.00 & 0.51 & 0.47 \\
\hline 2.50 & 0.59 & 0.56 \\
\hline 3.00 & 0.71 & 0.64 \\
\hline 3.50 & 0.79 & 0.72 \\
\hline 4.00 & 0.87 & 0.89 \\
\hline 4.50 & 1.07 & 1.08 \\
\hline 5.00 & 1.27 & 1.26 \\
\hline 5.50 & 1.42 & 1.42 \\
\hline 6.00 & 1.61 & 1.56 \\
\hline 6.50 & 1.66 & 1.70 \\
\hline \multicolumn{3}{|c|}{ Observation well PZ3 } \\
\hline 0.50 & 0.16 & 0.07 \\
\hline 1.00 & 0.23 & 0.13 \\
\hline 1.50 & 0.29 & 0.18 \\
\hline 2.00 & 0.34 & 0.23 \\
\hline 2.50 & 0.37 & 0.28 \\
\hline 3.00 & 0.42 & 0.33 \\
\hline 3.50 & 0.45 & 0.37 \\
\hline 4.00 & 0.52 & 0.46 \\
\hline 4.50 & 0.56 & 0.56 \\
\hline 5.00 & 0.64 & 0.65 \\
\hline 5.50 & 0.71 & 0.74 \\
\hline 6.00 & 0.81 & 0.82 \\
\hline 6.50 & 0.88 & 0.89 \\
\hline \multicolumn{3}{|c|}{ Observation well PZ5 } \\
\hline 0.66 & 0.10 & 0.15 \\
\hline 0.85 & 0.15 & 0.19 \\
\hline 1.16 & 0.21 & 0.25 \\
\hline 1.67 & 0.29 & 0.34 \\
\hline 1.95 & 0.34 & 0.39 \\
\hline 2.69 & 0.47 & 0.51 \\
\hline 6.73 & 1.41 & 1.46 \\
\hline \multicolumn{3}{|c|}{ Observation well PZ2 } \\
\hline 1.69 & 0.15 & 0.16 \\
\hline 2.64 & 0.37 & 0.24 \\
\hline 6.68 & 0.67 & 0.79 \\
\hline
\end{tabular}




\section{Supplement 4. Estimates of Hydraulic Conductivity from Specific Capacity Tests}

Data from seven production wells (center of fig. 22; table S4-1) were analyzed to determine transmissivity values for the Elm aquifer. Specific capacity tests, where the well was pumped at a constant rate and the drawdown was measured after 12 hours, were conducted on the seven wells when they were constructed in 2005. The static water levels indicated that this part of the aquifer was unconfined. The Theis and others (1963) method used in this analysis probably is the most common way to analytically estimate transmissivity from specific capacity (Mace, 2001). Well construction data included saturated thickness, well radius, pumping rate, drawdown, and pumping period. The specific yield, which is the storage term for unconfined aquifers, was assumed to be 0.10 because typical values range from $0.01-0.30$ for unconfined aquifers (Freeze and Cherry, 1979).

Transmissivity for the unconfined glacial till aquifer was calculated using a form of the Theis and others (1963) nonequilibrium equation:

$$
S_{c}=\frac{4 \pi T}{\left[\ln \left(\frac{2.25 T t_{p}}{r_{w}^{2} S}\right)\right]}
$$

where

$S_{c} \quad$ is specific capacity, in gallons per day per foot;

$\stackrel{c}{T} \quad=$ transmissivity, in gallons per day per foot;

$r_{w} \quad=$ radius of the well, in feet;

$S \quad=$ storativity, unitless; and

$t_{p} \quad=$ pumping time, in days.
The assumptions behind this equation are that the well is fully penetrating, the porous media is homogeneous and isotropic, the well loss is negligible, and the effective radius is equal to the radius of the production well (Mace, 2001). The equation was solved iteratively by rearranging equation S4A to solve for transmissivity $(T)$ in the numerator (equation S4B) according to Mace (2001):

$$
T=\frac{S_{c}}{4 \pi} \ln \left(\frac{2.25 T t_{p}}{r_{w}^{2} S}\right)
$$

Values for specific capacity $\left(S_{c}\right)$, pumping time $\left(t_{p}\right)$, and well radius $\left(r_{w}\right)$ were available from the well completion report, and an initial guess for the $T$ in the numerator was used to calculate the $T$ on the left side of the equation. The calculated $T$ was then substituted back into the equation, and this process was repeated using an iterative function until the $T$ on the left side was almost the same as the $T$ in the right side of the equation.

Based on this method, the average transmissivity for the Elm aquifer was determined to be $5,300 \mathrm{ft}^{2} / \mathrm{d}$, with a range of 2,550 to $8,180 \mathrm{ft}^{2} / \mathrm{d}$. Horizontal hydraulic conductivity for the Elm aquifer was calculated by dividing transmissivity by the saturated thickness of the aquifer. The average hydraulic conductivity was determined to be $143 \mathrm{ft} / \mathrm{d}$, with a range of 97 to $205 \mathrm{ft} / \mathrm{d}$ (table S4-1).

Table S4-1. Specific capacity data and estimated hydraulic conductivity for seven production wells in Aberdeen area.

[ft, feet; gal/min/ft, gallons per minute per foot; $\mathrm{ft} / \mathrm{d}$, feet per day]

\begin{tabular}{ccccccc}
\hline $\begin{array}{c}\text { Well identifier } \\
\text { (fig. 22) }\end{array}$ & $\begin{array}{c}\text { Saturated aquifer } \\
\text { thickness } \\
\text { (ft) }\end{array}$ & $\begin{array}{c}\text { Well radius } \\
\text { (ft) }\end{array}$ & $\begin{array}{c}\text { Pumping rate } \\
\text { (gal/min) }\end{array}$ & $\begin{array}{c}\text { Drawdown } \\
\text { (ft) }\end{array}$ & $\begin{array}{c}\text { Specific } \\
\text { capacity } \\
\text { (gal/min/ft) }\end{array}$ & $\begin{array}{c}\text { Estimated horizontal } \\
\text { hydraulic conductivity } \\
\text { (ft/d) }\end{array}$ \\
\hline J-1 & 35.1 & 0.5 & 390 & 17.7 & 22.0 & 117 \\
B-1 & 26.3 & 0.5 & 150 & 10.5 & 14.3 & 97 \\
B-2 & 35.1 & 0.5 & 400 & 13.4 & 29.9 & 162 \\
B-3 & 40.0 & 0.5 & 400 & 9.6 & 41.7 & 205 \\
B-4 & 29.5 & 0.5 & 200 & 11.4 & 17.5 & 108 \\
B-5 & 50 & 0.5 & 400 & 12.8 & 31.3 & 120 \\
B-6 & 38.8 & 0.5 & 400 & 10.5 & 38.1 & 191 \\
\hline
\end{tabular}




\section{Supplement 5. Estimating Vertical Hydraulic Conductivity of Sediments Separating the Elm River and Elm Aquifer using Temperature}

To examine the interaction of the Elm River and the Elm aquifer, a method that tracks energy exchange was used, primarily by using temperature measurements to estimate the hydraulic transport properties of the stream/groundwater system at a specific location. This section describes the temperature monitoring (figs. S5-1 and S5-2; tables S5-1 and S5-2), modeling method used in estimating vertical hydraulic conductivity from temperature gradients (table S5-3), and the temperature modeling results (figs. S5-3 through S5-14).

\section{Temperature Monitoring}

Temperature monitoring was conducted in 2008-09 at 11 sites along the Elm River (fig. 23) to estimate the Darcy velocities and the flow direction as described in the "Temperature Modeling" section. The equipment used to monitor the temperature gradient included stainless steel casing and programmed temperature loggers (fig. S5-1). A 3-ft screened steel well point was connected to steel casing that extended above the Elm River water surface. Solid pipe was used above the screened well point at four sites in 2008, and pipe with small (1/8-inch) holes was installed at seven sites in 2009. Two temperature loggers were placed within the casing, one near the bottom point and the other approximately 3-6 ft above the bottom logger. The casing was driven into the streambed at a slight angle towards the bank down to a depth so the bottom point was about 4-6 ft below the streambed surface at the edge of the stream. A third logger was placed directly in the stream near the casing to measure stream temperature. Water temperatures were recorded every 5 minutes.

Eleven driven piezometers were installed adjacent to the Elm River to determine the hydraulic gradient between the Elm River and Elm aquifer (table S5-1; fig. 23), with 6 of the 11 piezometers in the direct vicinity of temperature monitoring sites. The hydraulic gradient, in combination with the Darcy velocity, determined from analysis of the temperature data (see "Temperature Modeling" section) was used to calculate vertical hydraulic conductivity at six of the temperature monitoring sites (table S5-2). Water levels were measured periodically at the piezometer sites during May-September 2009. The stage of the Elm River near each

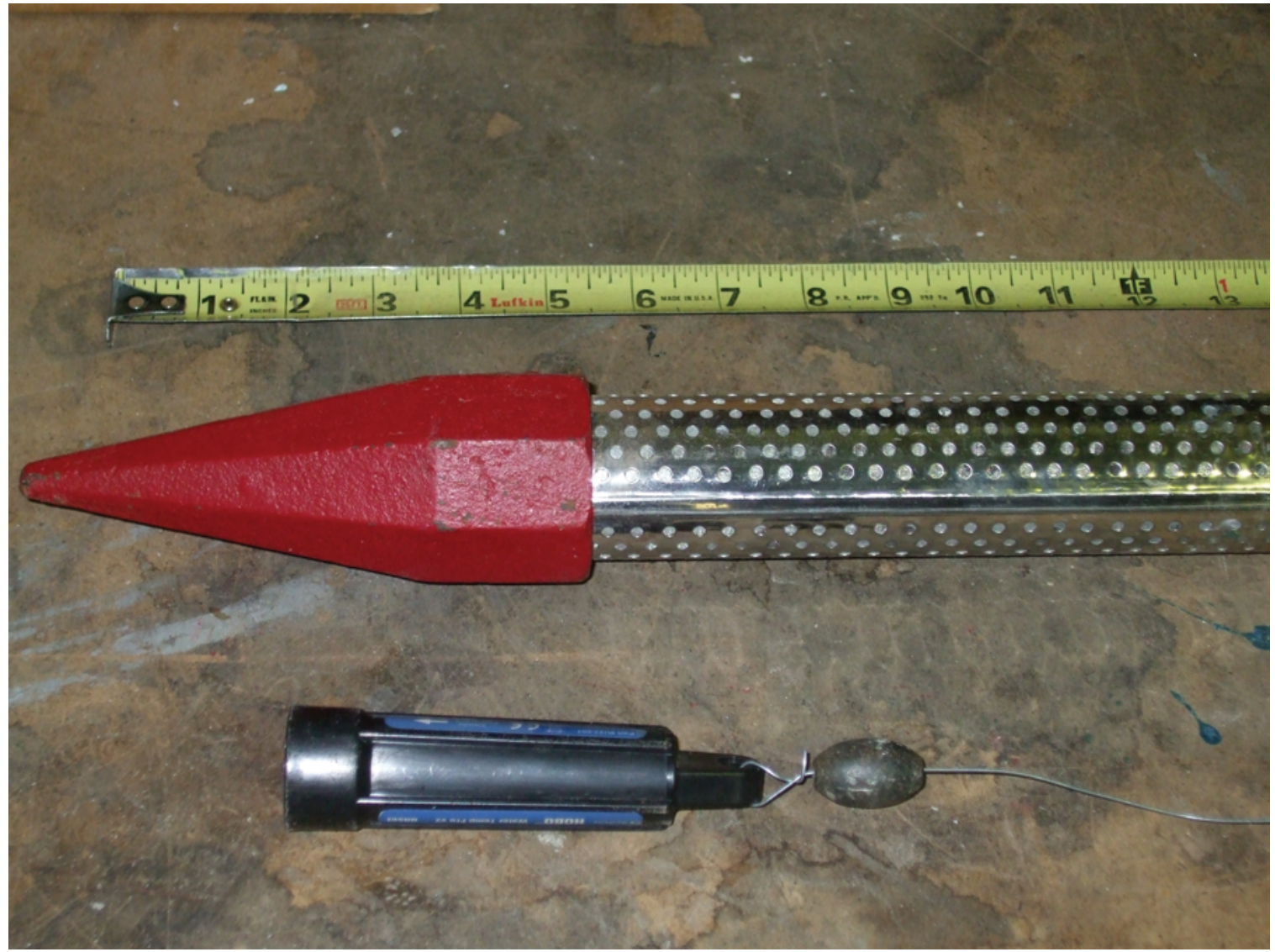

Figure S5-1. Stainless steel casing and temperature logger. 
A
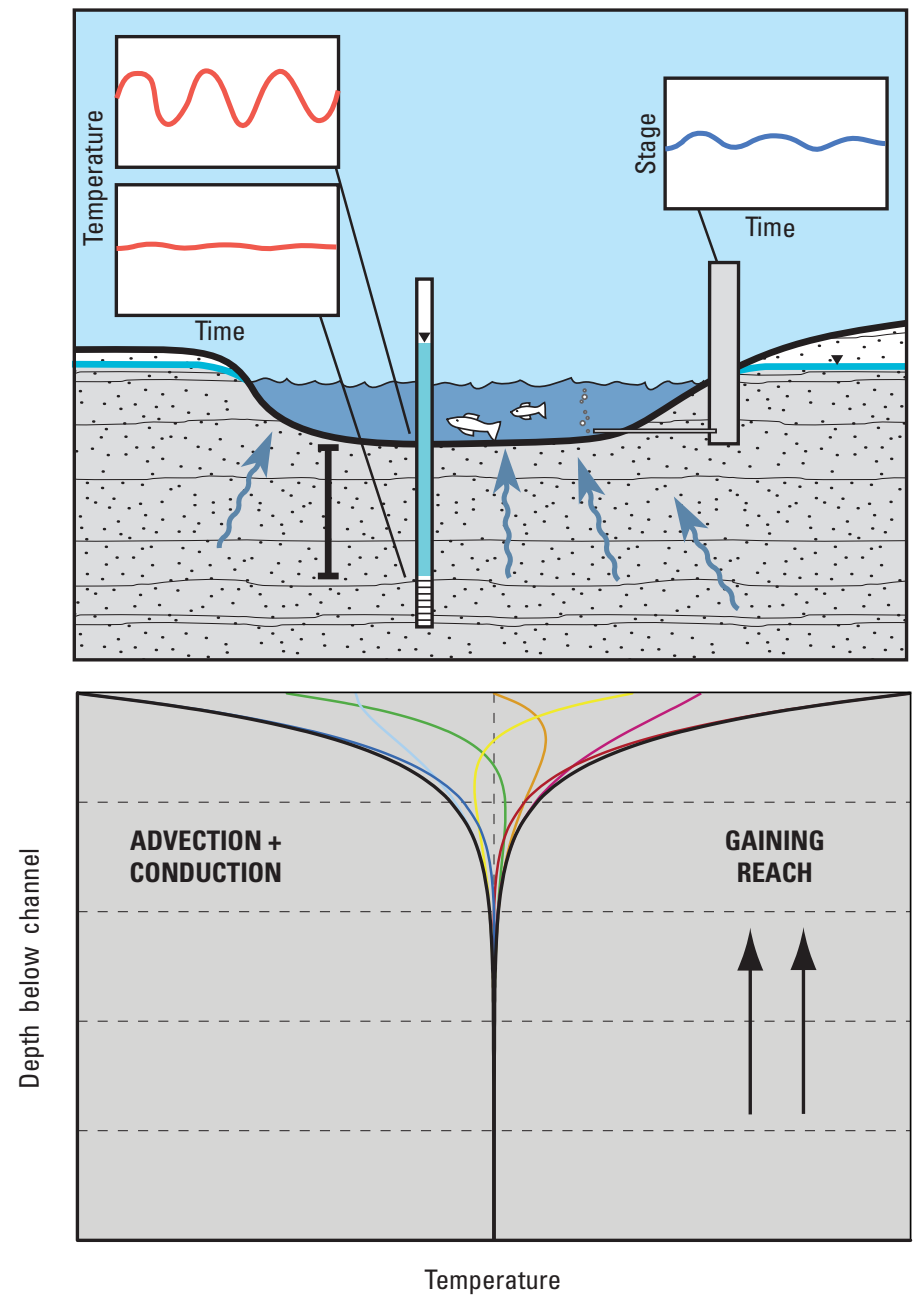

$B$
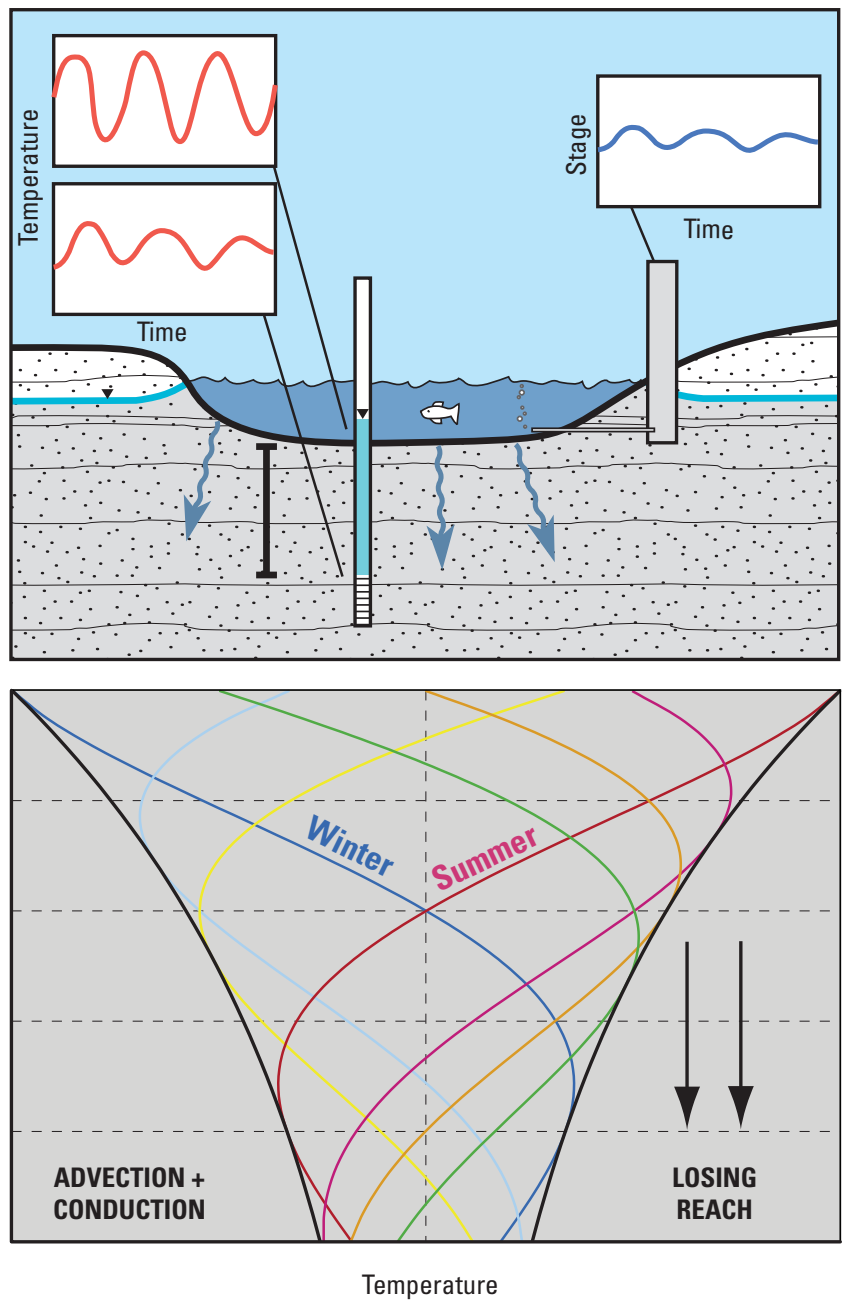

Figure S5-2. Cross-section representation of relative temperature variation in $A$, gaining and $B$, losing stream reaches (modified from Constantz and Stonestrom, 2003).

piezometer was estimated for each day that the water levels in the piezometers were measured. The Elm River stage was estimated using the stage record from streamgage 06471500 near Westport (fig. 1) and the surveyed altitude difference between the streamgage and the Elm River near the piezometer. Hydraulic gradients used in calculating hydraulic conductivity were based on average conditions of the Elm River stage and piezometer water-level measurements for May-September 2009.

\section{Temperature Modeling Method}

Natural variations in temperature can be used to track the heat carried by flowing water. Tracing the transport of heat leads to a better understanding of the magnitudes and mechanisms of stream/groundwater exchanges (Constantz and Stonestrom, 2003).
A simple evaluation of the diurnal variation of water temperature recorded at different depths may provide insight into whether the stream is gaining or losing streamflow at a specific location. The differences in diurnal temperature variation for streams gaining and losing streamflow is illustrated in figure S5-2. Streams gaining flow from groundwater will show a damped diurnal temperature pattern near the streambed; however, in a losing stream the water temperature at and below the streambed will vary similar to the stream surface temperature pattern. The difference in altitude between the water table and stream stage determines whether the stream is gaining or losing flow. Sediments and aquifer materials provide resistance to this flow, governing the rate at which water travels between ground and surface environments (Constantz and Stonestrom, 2003). As the resistance decreases (for example, coarser-grained sediments with more void space), the rate at which equilibrium is attained (water table and stream stage altitudes are equal) increases. This 
Table S5-1. Piezometers completed in the Elm aquifer near the Elm River.

[NAVD88, North American Vertical Datum of 1988; --, not determined]

\begin{tabular}{|c|c|c|c|c|c|c|c|c|c|c|c|}
\hline $\begin{array}{c}\text { Station } \\
\text { identification } \\
\text { number }\end{array}$ & $\begin{array}{c}\text { Site } \\
\text { identifier } \\
\text { in } \\
\text { downstream } \\
\text { order }\end{array}$ & $\begin{array}{l}\text { Land surface } \\
\text { altitude } \\
\text { (feet above } \\
\text { NAVD 88) }\end{array}$ & $\begin{array}{l}\text { Depth of } \\
\text { piezometer } \\
\text { below land } \\
\text { surface } \\
\text { (feet) }\end{array}$ & $\begin{array}{l}\text { Altitude of } \\
\text { top of Elm } \\
\text { aquifer } \\
\text { (feet above } \\
\text { NAVD 88) }\end{array}$ & $\begin{array}{l}\text { Maximum water- } \\
\text { level altitude, } \\
\text { May-September, } \\
2009 \\
\text { (feet above } \\
\text { NAVD 88) }\end{array}$ & $\begin{array}{c}\text { Minimum water- } \\
\text { level altitude, } \\
\text { May-September, } \\
2009 \\
\text { (feet above } \\
\text { NAVD 88) }\end{array}$ & $\begin{array}{l}\text { Mean water- } \\
\text { level altitude, } \\
\text { May-September, } \\
2009 \text { (feet above } \\
\text { NAVD 88) }\end{array}$ & $\begin{array}{l}\text { Mean Elm } \\
\text { River stage }^{1} \\
\text { (feet above } \\
\text { NAVD 88) }\end{array}$ & $\begin{array}{c}\text { Difference } \\
\text { between mean } \\
\text { Elm River stage } \\
\text { and Elm aquifer } \\
\text { water level } \\
\text { (feet) }\end{array}$ & $\begin{array}{l}\text { Approximate } \\
\text { altitude of } \\
\text { Elm River } \\
\text { bottom } \\
\text { (feet above } \\
\text { NAVD 88) }\end{array}$ & $\begin{array}{l}\text { Approximate thick- } \\
\text { ness of riverbed and } \\
\text { glacial till between } \\
\text { the aquifer top and } \\
\text { Elm River stage } \\
\text { (feet) }\end{array}$ \\
\hline 453954098310301 & PZ6 & $1,323.2$ & 11.0 & $1,313.7$ & $1,318.7$ & $1,318.0$ & $1,318.3$ & $1,317.4$ & 0.9 & 1,316 & 2 \\
\hline 453921098294801 & $\mathrm{PZ1}$ & $1,318.9$ & 14.5 & $1,305.9$ & $1,318.8$ & $1,317.0$ & $1,317.5$ & $1,314.7$ & 2.8 & 1,311 & 5 \\
\hline 453711098280201 & PZ7 & $1,313.3$ & 19.0 & $1,295.8$ & $1,310.9$ & $1,310.3$ & $1,310.5$ & $1,306.7$ & 3.8 & 1,303 & 7 \\
\hline 453622098284201 & PZ8 & $1,311.7$ & 24.0 & $1,289.2$ & $1,307.9$ & $1,307.4$ & $1,307.6$ & $1,306.7$ & 0.9 & 1,302 & 13 \\
\hline 453515098280601 & PZ9 & $1,313.4$ & 24.0 & $1,290.8$ & $1,307.6$ & $1,307.5$ & $1,307.5$ & $1,306.6$ & 0.9 & 1,301 & 10 \\
\hline 453508098273101 & PZ5 & $1,313.9$ & 18.0 & $1,297.4$ & $1,305.4$ & $1,303.2$ & $1,304.3$ & $1,306.6$ & -2.3 & 1,300 & 3 \\
\hline 453457098273301 & $\mathrm{PZ4}$ & $1,314.0$ & 20.0 & $1,295.5$ & $1,304.5$ & $1,303.0$ & $1,303.8$ & $\left({ }^{2}\right)$ & -- & $\left({ }^{2}\right)$ & $\left({ }^{2}\right)$ \\
\hline 453501098271401 & PZ3 & $1,318.3$ & 19.6 & $1,300.2$ & $1,305.1$ & $1,302.4$ & $1,303.6$ & $1,306.5$ & -2.9 & 1,299 & $\left({ }^{3}\right)$ \\
\hline 453457098271401 & PZ2 & $1,315.9$ & 22.0 & $1,295.4$ & $1,304.9$ & $1,301.7$ & $1,303.7$ & $\left({ }^{2}\right)$ & -- & $\left({ }^{2}\right)$ & $\left({ }^{3}\right)$ \\
\hline 453436098260101 & PZ10 & $1,310.9$ & 19.0 & $1,293.4$ & $1,311.2$ & $1,310.2$ & $1,310.8$ & $\left({ }^{2}\right)$ & -- & $\left({ }^{2}\right)$ & $\left({ }^{2}\right)$ \\
\hline 453424098260101 & PZ11 & $1,312.7$ & 19.0 & $1,295.2$ & $1,308.2$ & $1,305.1$ & $1,306.8$ & $1,306.4$ & 0.4 & 1,297 & 2 \\
\hline
\end{tabular}

${ }^{1}$ Estimated from relation between stage height at U.S. Geological Survey streamgage 06471500 and surveyed river stage near the piezometer site.

${ }^{2}$ Piezometer set back from Elm River.

${ }^{3}$ Elm River incised into Elm aquifer with hydraulic connection limited by fine sediments deposited on river bottom. 
Table S5-2. Darcy velocity, hydraulic gradient, and vertical hydraulic conductivity at temperature monitoring sites.

$[--$, not applicable $]$

\begin{tabular}{ccccccc}
\hline $\begin{array}{c}\text { Temperature } \\
\text { logger site }\end{array}$ & $\begin{array}{c}\text { Year } \\
\text { monitored }\end{array}$ & $\begin{array}{c}\text { Nearest } \\
\text { piezometer } \\
\text { site }\end{array}$ & $\begin{array}{c}\text { Gaining } \\
\text { or losing } \\
\text { streamflow }\end{array}$ & $\begin{array}{c}\text { Darcy velocity } \\
\text { (feet per day) }\end{array}$ & $\begin{array}{c}\text { Hydraulic } \\
\text { gradient } \\
\text { (feet per foot) }\end{array}$ & $\begin{array}{c}\text { Effective vertical } \\
\text { hydraulic } \\
\text { conductivity } \\
\text { (feet per day) }\end{array}$ \\
\hline T1 & 2008 & -- & Gaining & 0.30 & -- & -- \\
T2 & 2008 & -- & Neutral & 0.00 & -- & -- \\
T2 & 2009 & PZ8 & Gaining & 0.07 & 0.07 & 1.00 \\
T3 & 2008 & -- & Gaining & 0.50 & -- & -- \\
T4 & 2008 & -- & Neutral & 0.00 & -- & -- \\
T5 & 2009 & PZ1 & Gaining & 0.50 & 0.202 & 2.48 \\
T6 & 2009 & PZ3 & Losing & 0.06 & 0.433 & 0.14 \\
T7 & 2009 & PZ6 & Gaining & 0.25 & 0.187 & 1.34 \\
T8 & 2009 & PZ7 & Gaining & 0.10 & 0.352 & 0.28 \\
T9 & 2009 & PZ9 & Gaining & 0.10 & 0.062 & 1.62 \\
T10 & 2009 & -- & Gaining & 0.05 & -- & -- \\
T11 & 2009 & -- & Gaining & 0.06 & -- & -- \\
\hline
\end{tabular}

equilibrium condition is referred to as a neutral reach, where no net gain or loss in either the surface-water or groundwater system happens.

Numerical modeling of energy (temperature) may be used to determine specific hydraulic properties of the stream/groundwater system, such as hydraulic conductivity. Lapham (1989) summarized the method to develop a model that describes vertical groundwater flow for a gaining, neutral, or losing stream location. In this model, heat carried by advection (bulk fluid movement of groundwater) and conduction (spontaneous transfer by direct contact) is represented by changes in temperature over time at different depth locations below the streambed. Using known temperature measurements at specific depths below the stream, Darcy velocity (flow through a unit area, also called specific discharge) can be calculated from the advective transport portion of the model.

For one-dimensional, vertical isothermal flow of an incompressible fluid through homogenous, porous media, the general equation describing the simultaneous flow of fluid and heat in the earth is (Lapham, 1989)

$$
k \frac{\partial^{2} T}{\partial z^{2}}-v_{z} c_{w} \rho_{w} \frac{\partial T}{\partial z}=c \rho \frac{\partial T}{\partial t}
$$

where

$k=$ thermal conductivity of the sediment-fluid matrix, in watts per meter per degree Celsius;

$T=$ temperature at any point $z$ at any time $t$, in degrees Celsius;

$c_{w} \quad=$ volumetric heat capacity of the fluid, in joules per cubic meter per degree Celsius;

$\rho_{w} \quad=$ specific density of the fluid, unitless;

$v_{z} \quad=$ Darcian fluid velocity in the $z$ direction, in meters per second;

$c=$ volumetric heat capacity of the sediment-fluid matrix, in joules per cubic meter per degree Celsius; and

$\rho \quad=$ wet-bulk specific gravity (density of the sediment-fluid matrix), unitless.

An explicit finite-difference approximation to equation S5A is (Lapham, 1989)

$$
T_{i}^{n+1}=\frac{k \Delta t}{\rho c \Delta z^{2}}\left(1+\frac{\rho_{w} c_{w} v_{z} \Delta z}{2 k}\right) T_{i-1}^{n}+\frac{k \Delta t}{\rho c \Delta z^{2}}\left(1-\frac{\rho_{w} c_{w} v_{z} \Delta z}{2 k}\right) T_{i+1}^{n}+\left(1-\frac{2 k \Delta t}{\rho c \Delta z^{2}}\right) T_{i}^{n}
$$


where

$$
\begin{array}{cc}
T_{i}^{n+1} & \text { temperature at node } i, \text { in degrees Celsius at } \\
& \text { time step } n+1, \text { in seconds; } \\
T_{i-1}{ }^{n} & =\text { temperature at node } i-1, \text { in degrees Celsius } \\
& \quad \text { at time step } n, \text { in seconds; } \\
T_{i+1}{ }^{n} & =\text { temperature at node } i+1, \text { in degrees Celsius } \\
& \quad \text { at time step } n, \text { in seconds; } \\
\Delta t \quad= & \text { time increment between time steps, in } \\
\quad & \text { seconds; and } \\
\Delta z \quad= & \text { spacing between nodes, in meters. }
\end{array}
$$

\section{Temperature Modeling}

One-dimensional temperature profiles were simulated using the numerical solution presented in equation S5B (Lapham, 1989). Using the observed Elm River time-series data with a constant time step and known spacing between observation nodes, the model was set up in a spreadsheet and initialized with typical physical and thermal properties from literature (Stonestrom and Blasch, 2003). These properties represent characteristics of the groundwater system in the immediate vicinity of the temperature loggers and are assumed constant over the simulation period. These parameters were varied simultaneously to minimize the sum of the absolute error between the temperature at locations with simulated and observed temperatures below the streambed. After estimation of the physical properties of the subsurface sediments (table S5-3), the Darcy velocity of the groundwater/surfacewater system was used as a final calibration parameter of the model for all sites (table S5-2). The observed and simulated temperatures at the 11 sites along the Elm River are shown in figures S5-3 through S5-14. Simulated temperature agreed relatively well with observed temperature at known spatial and temporal positions. The average absolute error in the temperature models ranged from 0.35 to 3.09 degrees Celsius.
Estimates of vertical seepage (Darcy velocity) from simulation of temporal temperature gradients (table S5-2) and hydraulic gradients (table S5-1) were used to estimate the vertical hydraulic conductivity of the sediments separating the Elm aquifer and the Elm River.

Hydraulic conductivity through sediments was estimated using Darcy's Law (Freeze and Cherry, 1979):

$$
\frac{Q}{A}=v=k * \frac{\Delta h}{L}
$$

where

$$
\begin{aligned}
Q \quad= & \text { groundwater discharge, in cubic feet per } \\
& \text { day; } \\
A \quad= & \text { unit area, in square feet; } \\
v= & \text { Darcy velocity, in feet per day; } \\
k \quad= & \text { hydraulic conductivity, in feet per day; } \\
\Delta h / L \quad= & \text { hydraulic gradient or change in hydraulic } \\
& \text { head through the length of the flow path, in } \\
& \text { feet per foot. }
\end{aligned}
$$

The hydraulic gradient, which is the change in hydraulic head through the length of the flow path, was the difference between the Elm River stage and the hydraulic head in the Elm aquifer.

Darcy velocities estimated from temperature modeling (table S5-2) show that the Elm River experiences spatial variation in the groundwater/surface-water interactions throughout the study area. The Elm River is gaining streamflow at a rate of about $0.30 \mathrm{ft} / \mathrm{d}$ (through the streambed area) near site T1, about neutral near site $\mathrm{T} 2$, and gaining streamflow at a rate of about $0.50 \mathrm{ft} / \mathrm{d}$ near sites T3 and T5. The Elm River likely is losing streamflow near site T6 at a rate of about $0.06 \mathrm{ft} / \mathrm{d}$, possibly explained by the proximity to the Eyestone Pit and production wells. Vertical hydraulic conductivities ranged from 0.14 to $2.48 \mathrm{ft} / \mathrm{d}$ (table S5-2).

Table S5-3. Thermal and physical properties used in the finite-difference approximation of energy transport.

$\left[\mathrm{W} / \mathrm{m}-{ }^{\circ} \mathrm{C}\right.$, watts per meter per degree Celsius; $\mathrm{J} / \mathrm{m}^{3}-{ }^{\circ} \mathrm{C}$, joules per cubic meter per degree Celsius]

\begin{tabular}{ccc}
\hline $\begin{array}{c}\text { Property } \\
\text { (equation S5A) }\end{array}$ & Value & Units \\
\hline$k$ & 3.06 & $\mathrm{~W} / \mathrm{m}-{ }^{\circ} \mathrm{C}$ \\
$c_{w}$ & $4,200,000$ & $\mathrm{~J} / \mathrm{m}^{3}-{ }^{\circ} \mathrm{C}$ \\
$\rho_{w}$ & 1.0 & Unitless \\
$c$ & $2,300,000$ & $\mathrm{~J} / \mathrm{m}^{3}-{ }^{\circ} \mathrm{C}$ \\
$\rho$ & 2.2 & Unitless \\
\hline
\end{tabular}




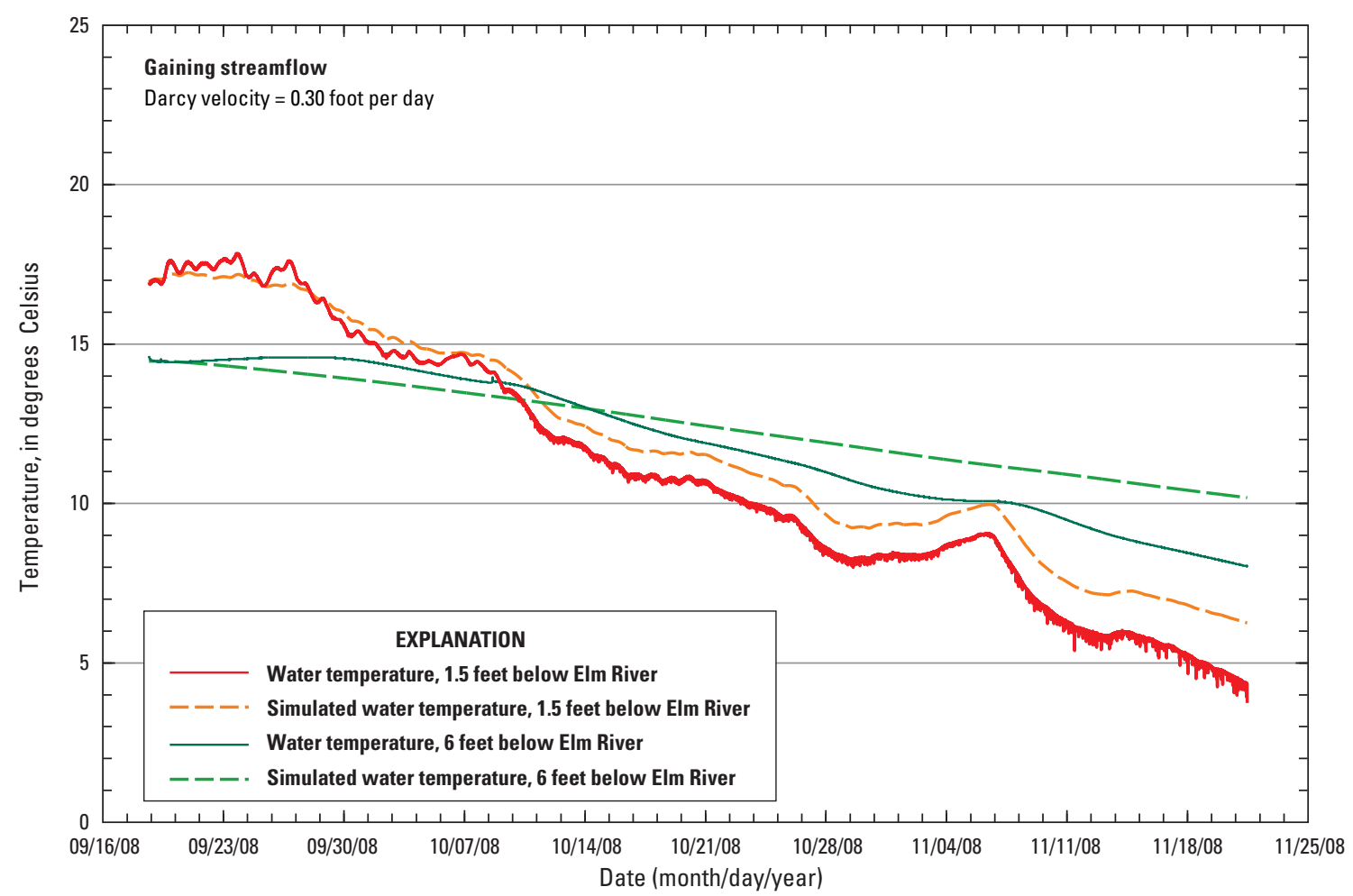

Figure S5-3. Observed and simulated temperature for site T1.

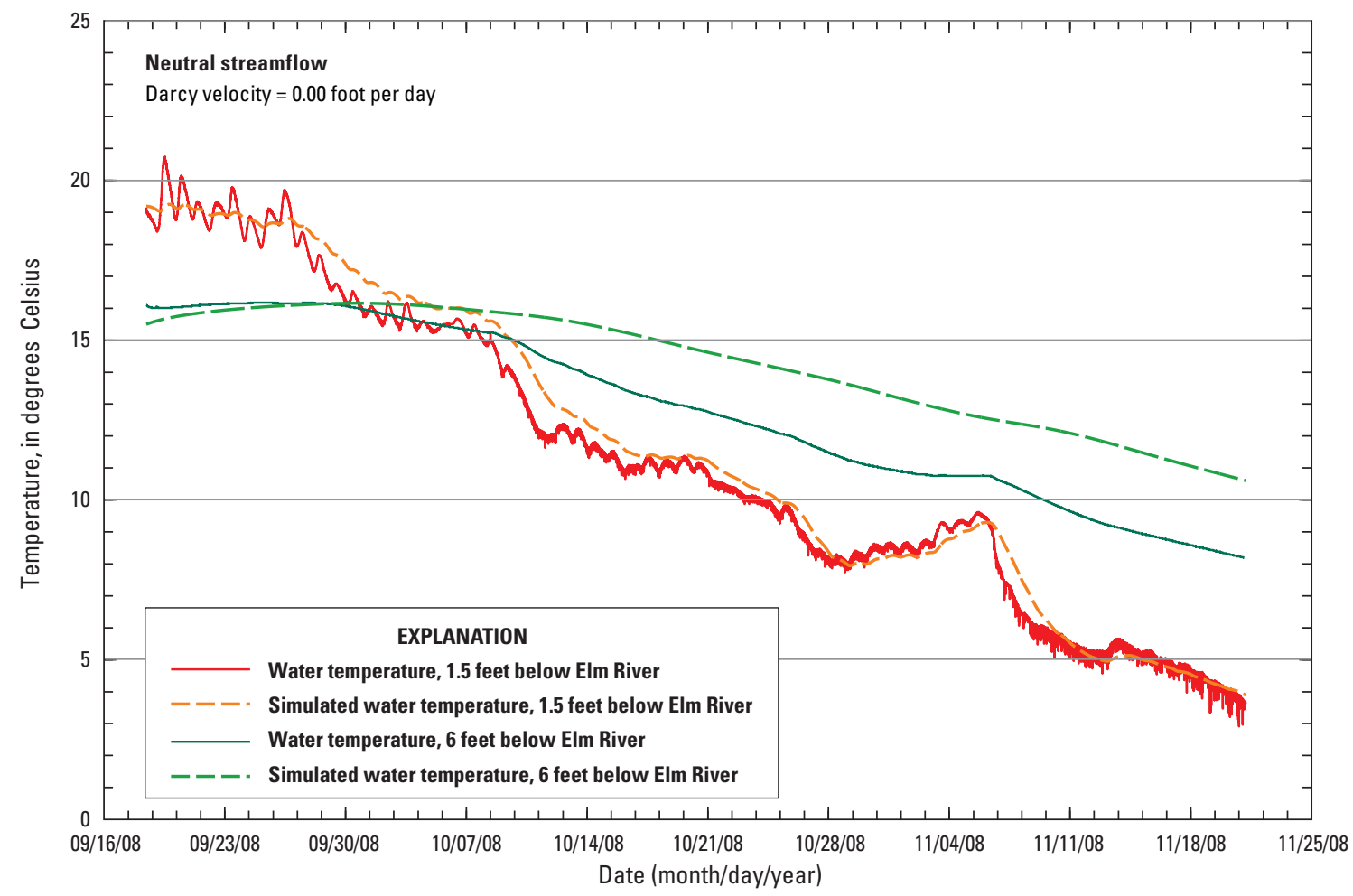

Figure S5-4. Observed and simulated temperature for site T2, 2008. 


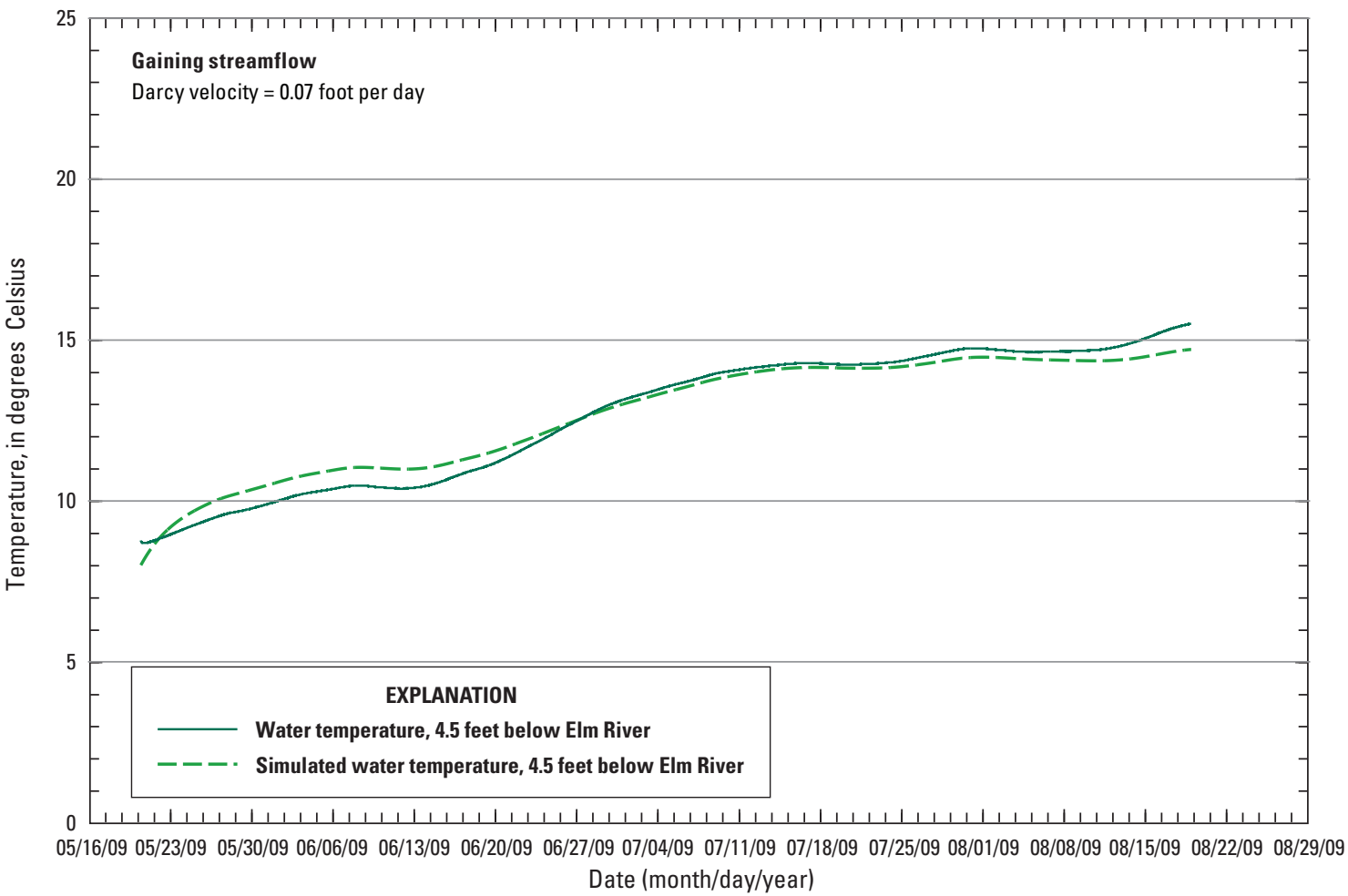

Figure S5-5. Observed and simulated temperature for site T2, 2009.

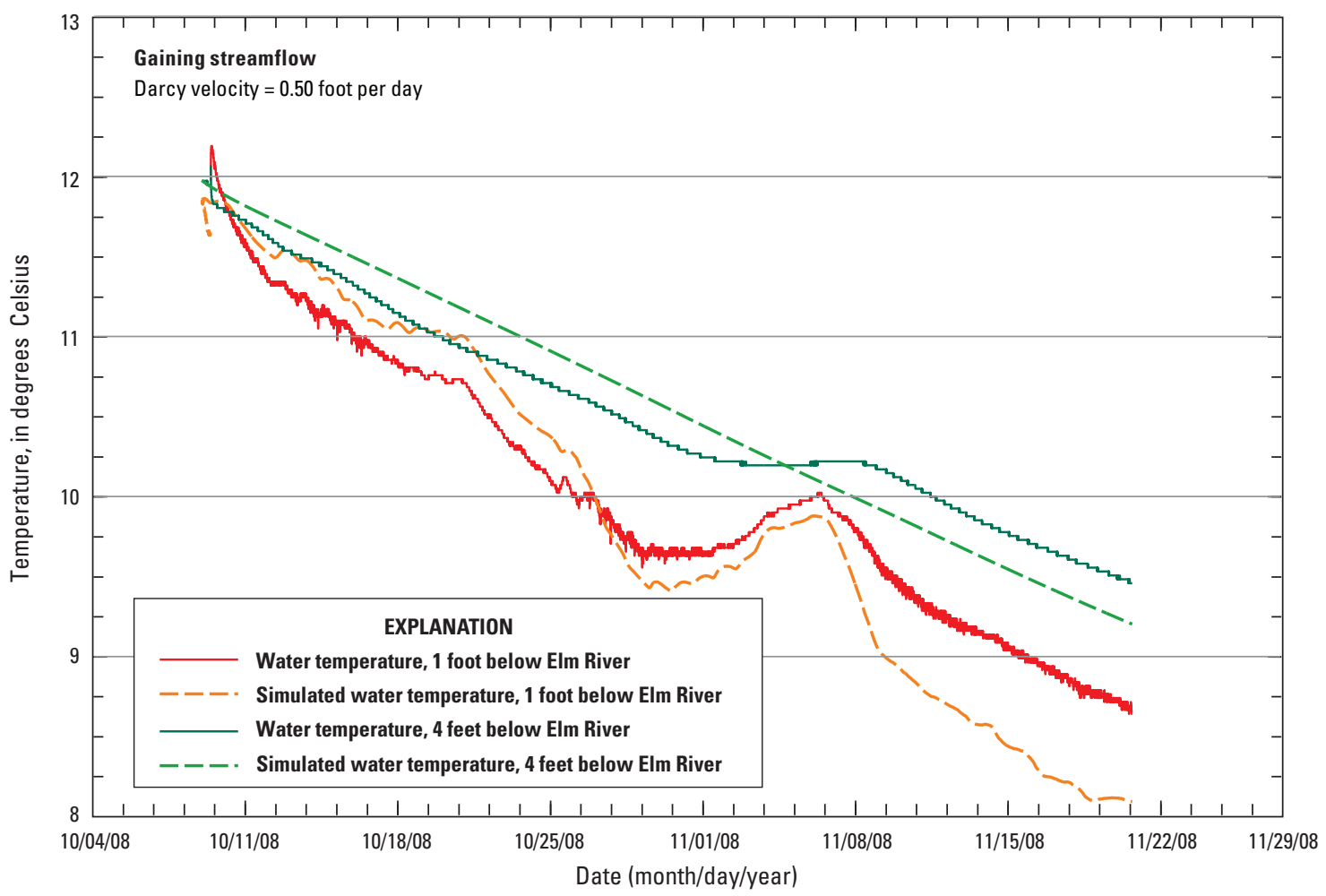

Figure S5-6. Observed and simulated temperature for site T3. 


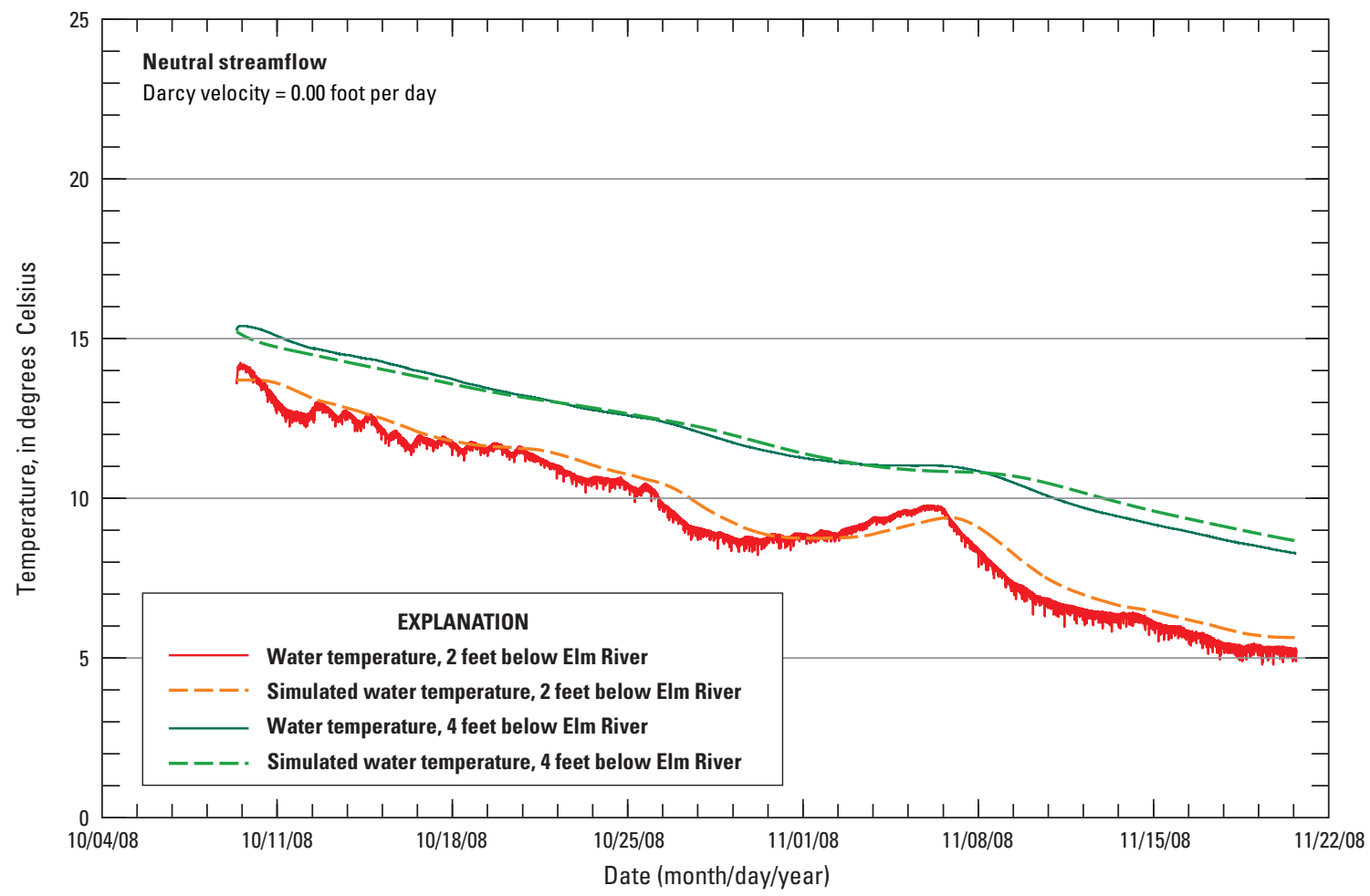

Figure S5-7. Observed and simulated temperature for site T4.

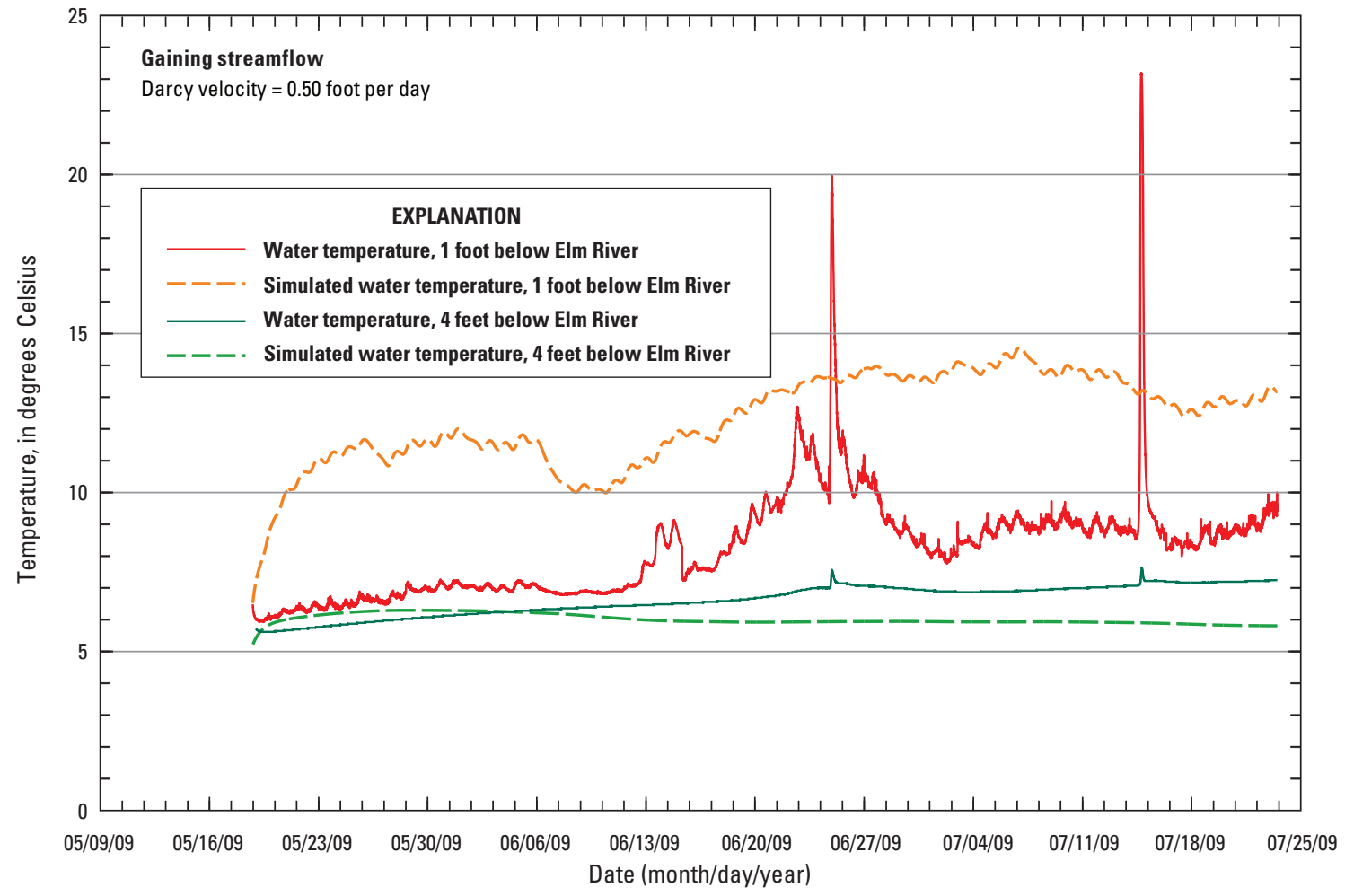

Figure S5-8. Observed and simulated temperature for site T5. 


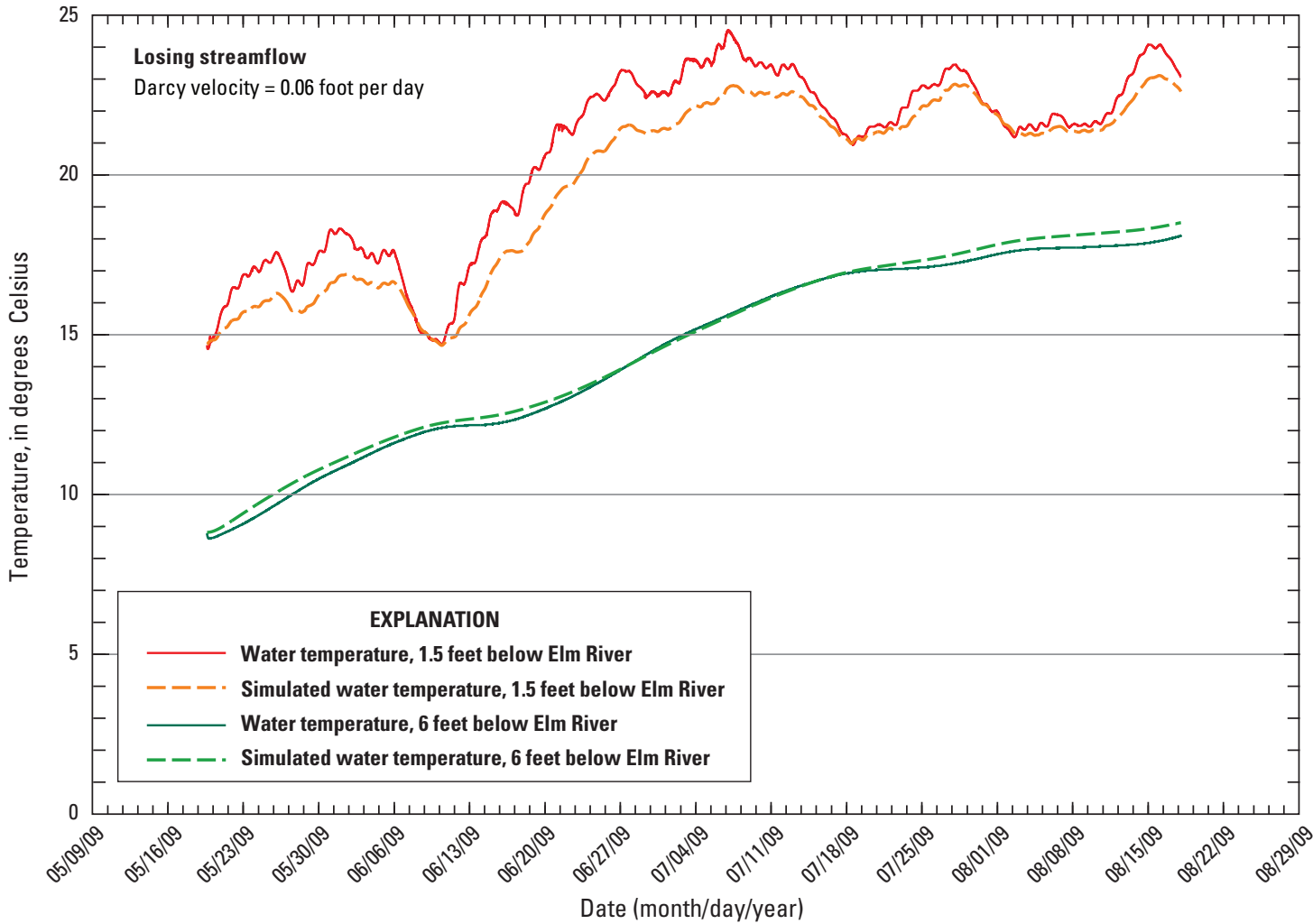

Figure S5-9. Observed and simulated temperature for site T6.

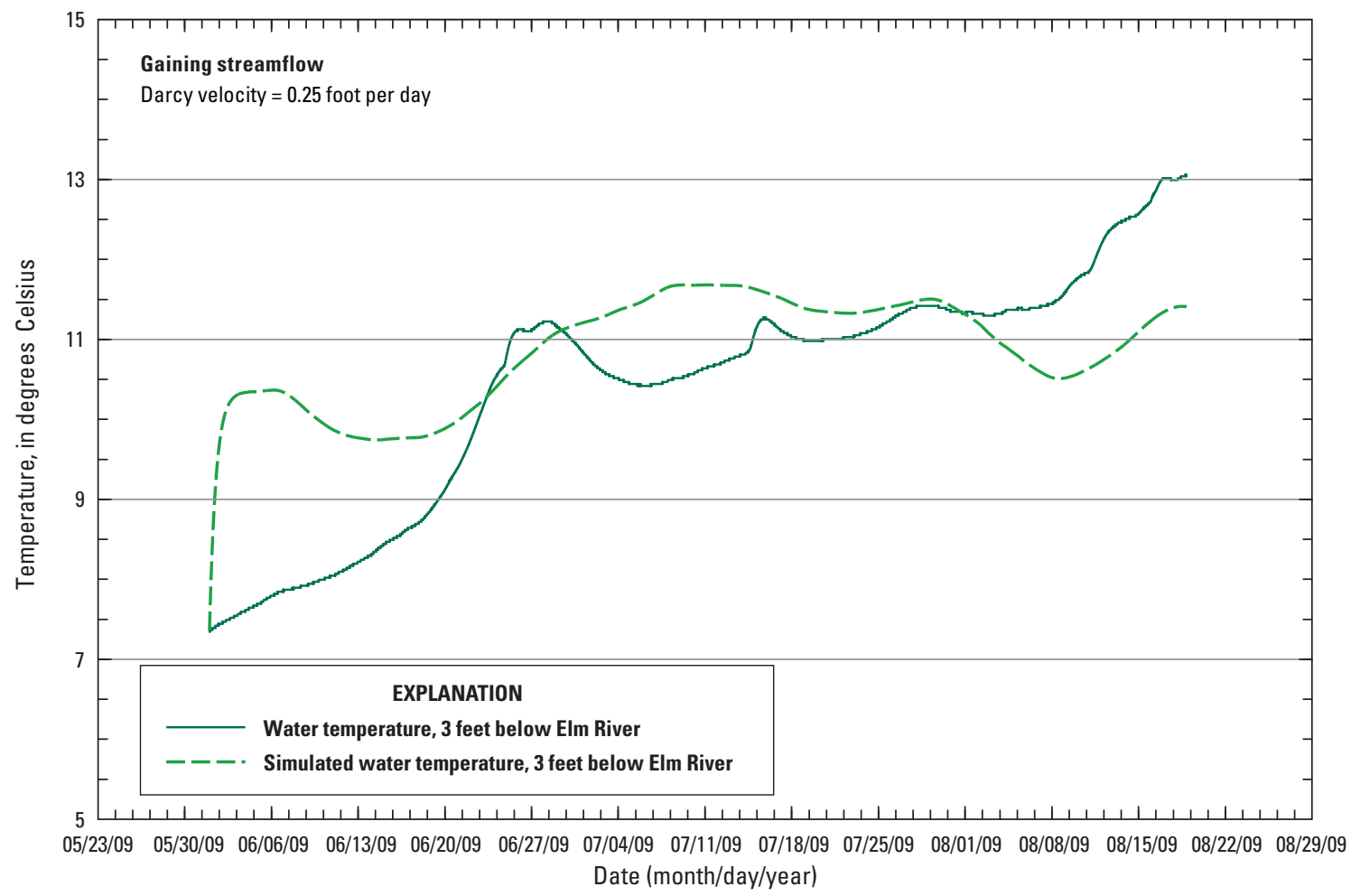

Figure S5-10. Observed and simulated temperature for site T7. 


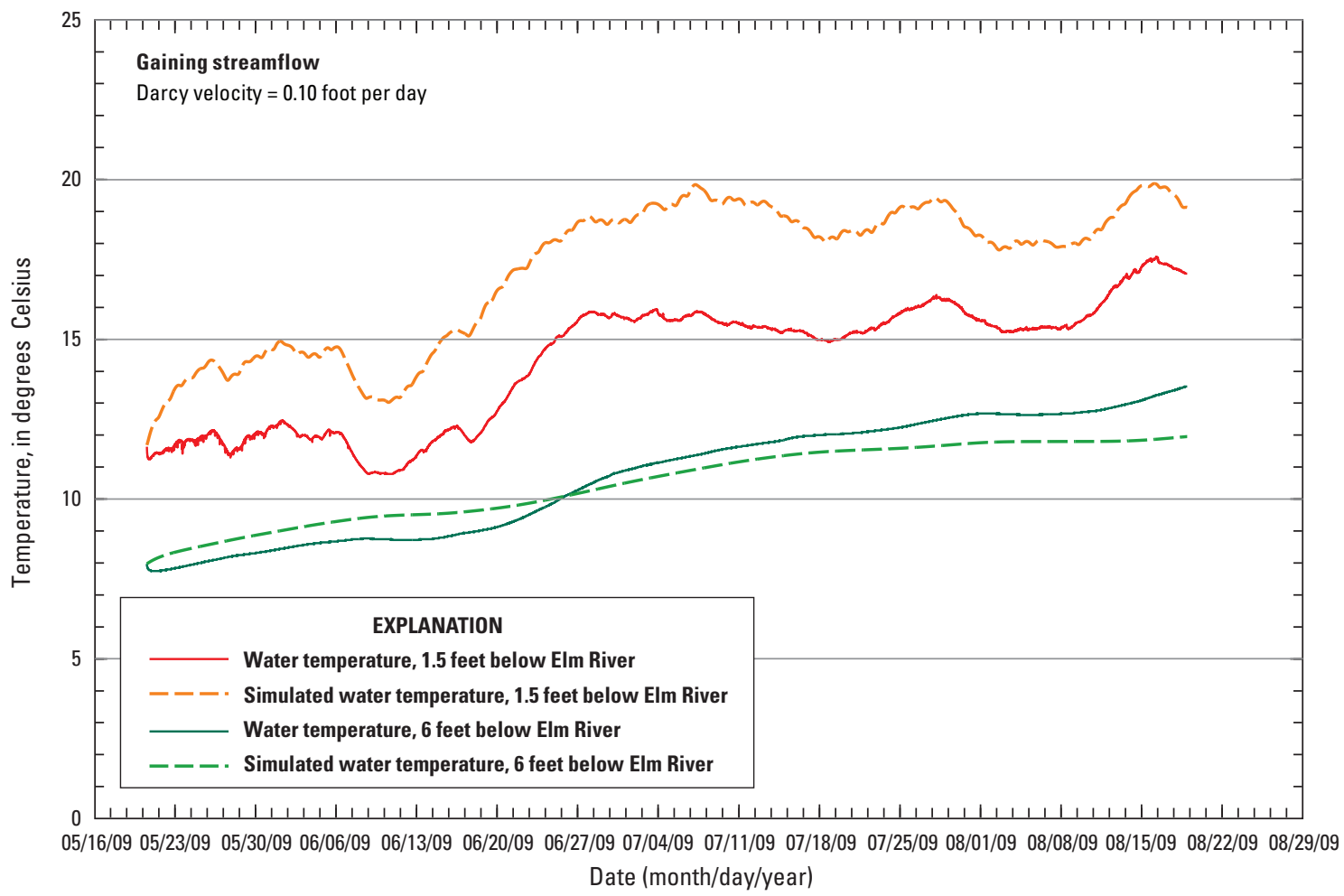

Figure S5-11. Observed and simulated temperature for site T8.

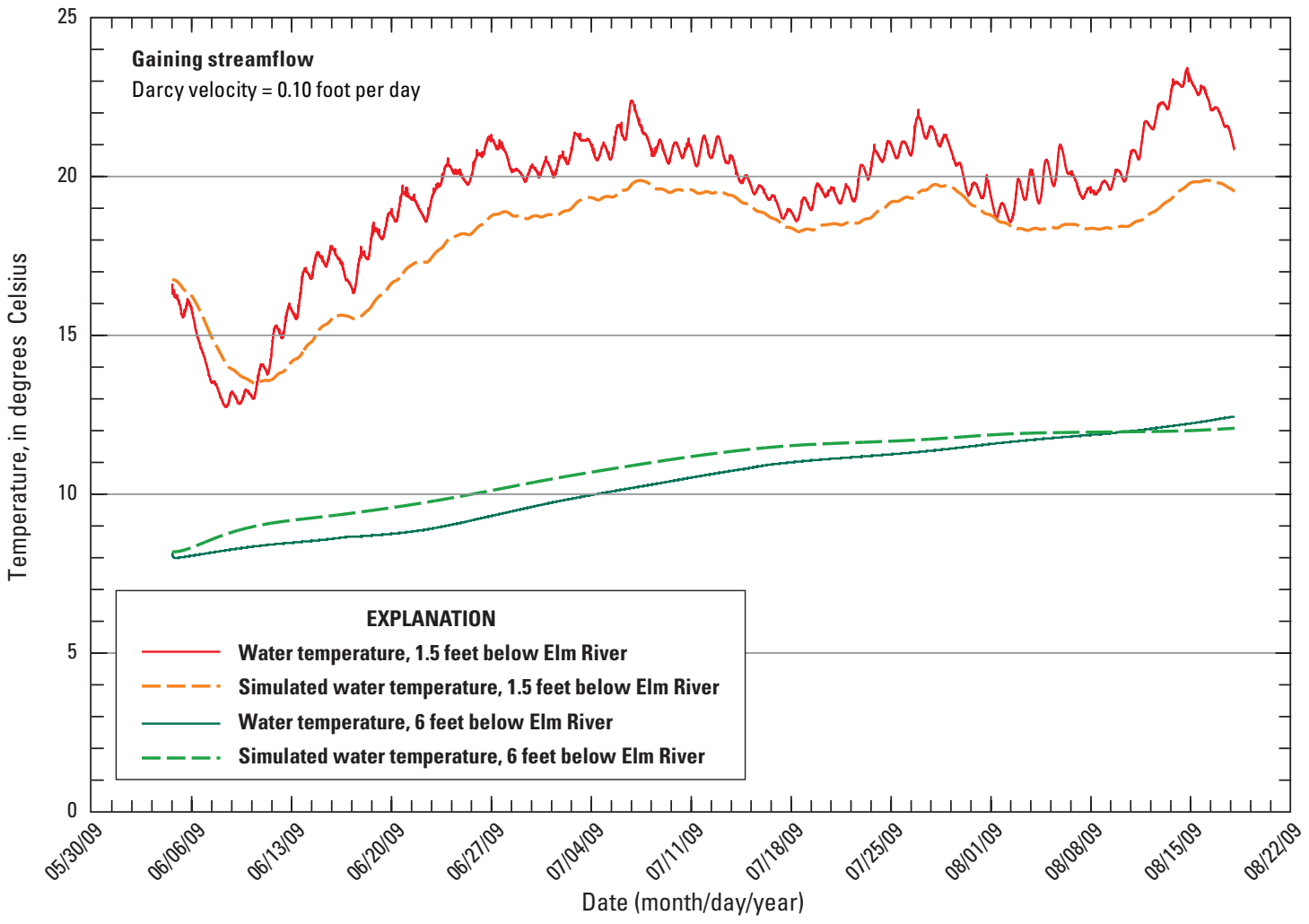

Figure S5-12. Observed and simulated temperature for site T9. 


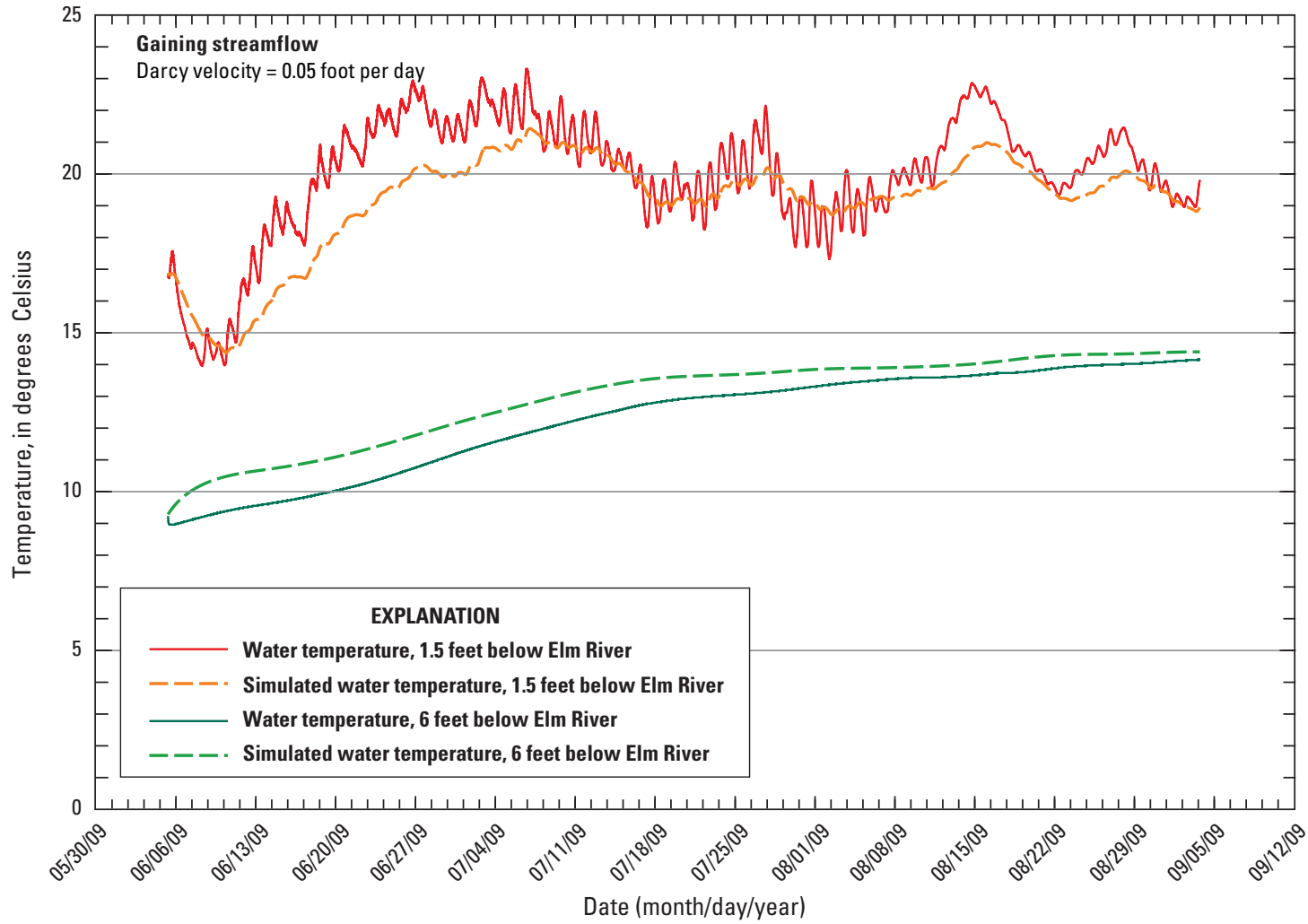

Figure S5-13. Observed and simulated temperature for site T10.

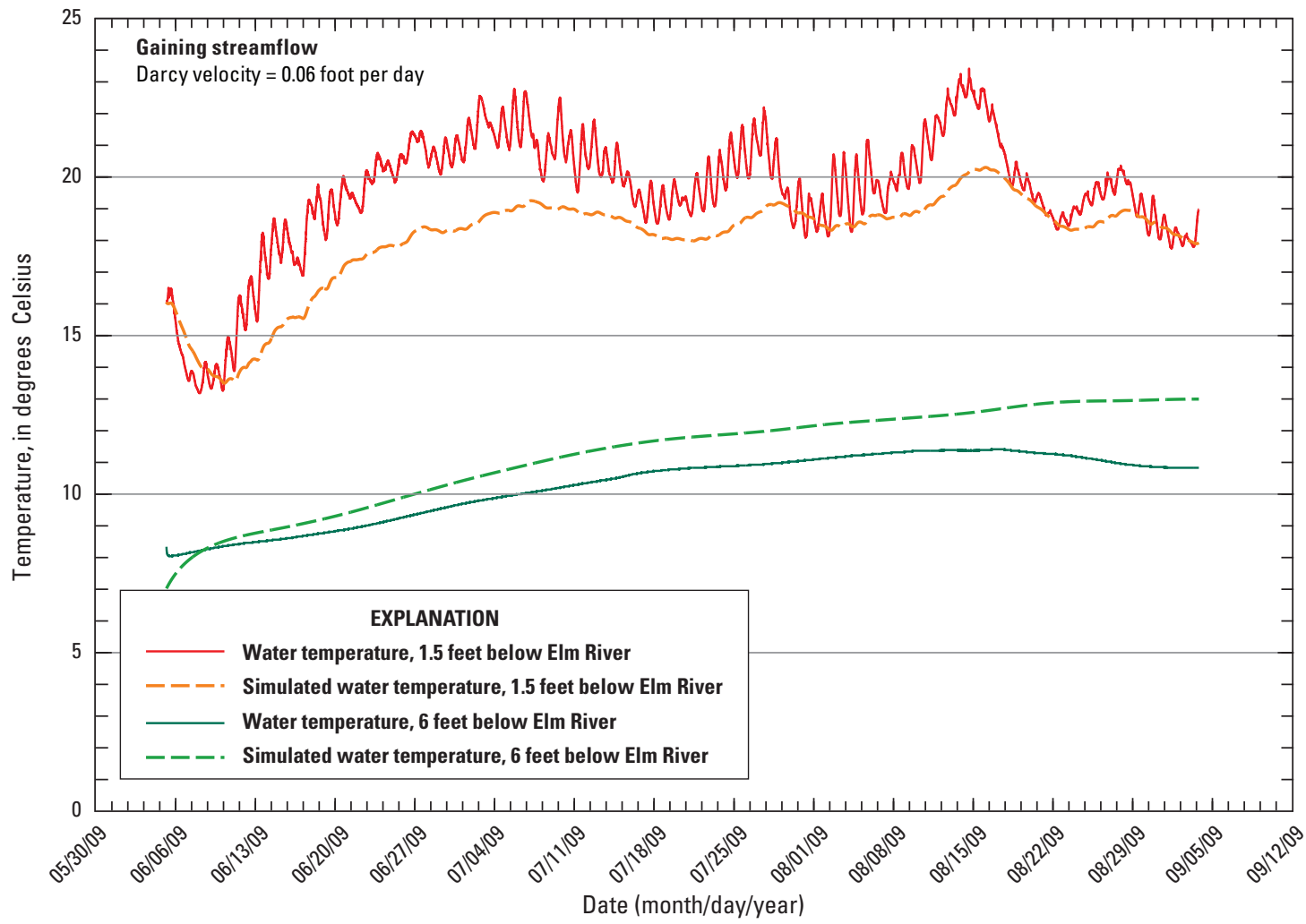

Figure S5-14. Observed and simulated temperature for site T11. 


\section{Supplement 6. Analysis of Recharge with a Soil-Water- Balance Method}

This section describes the use of a soil-water-balance (SWB) method, using the SWB program by Westenbroek and others (2010), to determine the amount of recharge available to the Elm aquifer. The infiltration rate used in recharge calculations is presented in table S6-1 according to soil type and till thickness overlying the Elm aquifer. The distribution of soil types is presented in figure $\mathrm{S} 6-1$.

Table S6-1. Infiltration rates assigned by soil type and till thickness.

[>, greater than; --, not applicable]

\begin{tabular}{ccccccc}
\hline Till thickness, & \multicolumn{6}{c}{ Infiltration rate for soil type, in inches per day } \\
\cline { 2 - 7 } in feet & A & B & BC & C & CD & D \\
\hline $0-10$ & 7.20 & 3.60 & 2.40 & 1.20 & 0.72 & 0.24 \\
$>10-20$ & 2.00 & 1.00 & 1.00 & 1.00 & 0.72 & 0.24 \\
$>20-30$ & -- & 0.50 & 0.50 & 0.50 & 0.50 & 0.24 \\
$>30$ & -- & 0.01 & 0.01 & 0.01 & 0.01 & 0.01 \\
\hline
\end{tabular}

The SWB program makes use of daily precipitation and temperature data with land use, soil type, root depth, and runoff flow direction to calculate runoff, evapotranspiration, and recharge. The SWB program can account for frozen ground, snowfall, snowmelt, and the dependency of recharge on the timing and spatial distribution of precipitation. The modified Thornthwaite-Mather soil-water accounting is used to calculate recharge by using equation S6A:

recharge $=($ precipitation + snowmelt + inflow $)-($ interception + outflow + ET $)-\Delta$ soil moisture

where

precipitation, snowmelt, and inflow are sources; interception, outflow, and evapotranspiration (ET) are sinks; and

$\Delta$ soil moisture is the change in soil moisture as the amount of water added to or lost from the soil, with the maximum set by the holding capacity of the soil and the minimum set by the wilting point.

Runoff is calculated through the following equation (Westenbroek and others, 2010):

$$
R=\frac{\left(P-I_{a}\right)^{2}}{\left(P+\left[S_{\max }-I_{a}\right]\right)}
$$

where

$$
\begin{aligned}
P & \text { is greater than } I_{a}, \text { in inches; } \\
R & =\text { runoff, in inches; } \\
P & =\text { daily precipitation, in inches; } \\
I_{a} & =\text { initial abstraction, the amount of precipitation that must fall before any } \\
& \text { runoff is generated, in inches; and } \\
S_{\max } & =\text { maximum soil-moisture holding capacity, in inches. }
\end{aligned}
$$


Initial abstraction $\left(I_{a}\right)$ is related to maximum soil-moisture holding capacity $\left(S_{\max }\right)$ through the following equation (Westenbroek and others, 2010):

$$
I_{a}=0.2 S_{\max }
$$

The maximum soil-moisture holding capacity $\left(S_{\max }\right)$ is based on the Natural Resources Conservation Service curve number ( $C N$; Curve Number Work Group, 2004) for a soil by using the following equation (Westenbroek and others, 2010):

$$
S_{\max }=\left(\frac{1000}{C N}\right)-10
$$

Data from seven National Oceanic and Atmospheric Administration precipitation stations (Aberdeen Regional Airport, 390020; Aberdeen 2E, 390020; Bath 1NE, 390553; Columbia 1S, 391884; Columbia 8N, 391873; Westport, 399138; and Westport 1N, 399136) were used for the climate inputs to the SWB program (National Climate Data Center, 2011; fig. 1). The Aberdeen Regional Airport and Columbia 8N stations had temperature data for 1975-2009, and the temperatures were averaged for each day unless one station did not have data for that particular day (National Climate Data Center, 2011). When the temperature was only recorded at one station, that value was used in place of a temperature averaged between the two stations. A third station, Aberdeen $2 \mathrm{E}$, had been assigned the same station number as the airport and produced duplicate data over part of the period of record (National Climate Data Center, 2011). Temperature and precipitation data were only used from this station when no data were available from the airport. Precipitation data were averaged from all stations with a record of the given day to provide one value that could be entered into the SWB program. The precipitation data were in water equivalent inches when the precipitation came in the form of snow (National Climate Data Center, 2011), and the SWB program used temperature data to determine when precipitation was snow (Westenbroek, 2010). The Hargreaves-Samani method of evapotranspiration calculation was chosen for use in the SWB program because only minimum, maximum, and average temperature and precipitation data were required on a daily time step (Westenbroek and others, 2010).

The flow direction grid was created from the 10-m (33-ft) digital elevation model of the study area (U.S. Geological Survey, 2006). The SWB program only allows runoff to flow in one direction from a cell (Westenbroek and others, 2010), so cells that could have multiple runoff directions from the digital elevation model were examined and modified. If the cell allowed runoff into multiple cells along one direction, the flow direction was set to the central or most representative cell. If the runoff could flow in opposite directions, the cell was assigned an arbitrary number that was used for all "depression" cells. All depressions were allowed to infiltrate water from runoff the day the runoff was generated, but any ponding was removed at the start of the next day (Westenbroek and others, 2010). The continuous frozen ground index (in degrees Celsius-days) was used to increase the runoff resulting from precipitation or snowmelt that happens while the ground is frozen (Westenbroek and others, 2010). Antecedent moisture conditions are considered from the previous 5 days (Westenbroek and others, 2010).

The hydrologic soil groups were assigned as A, B, $\mathrm{BC}, \mathrm{C}, \mathrm{CD}$, and D on the basis of soil survey data (Natural Resources Conservation Service, 2009a) with similar additional soil groups in the SWB program used to account for the thickness of till above the aquifer. Soil group A has the highest infiltration rate, and soil group D has the lowest infiltration rate (Natural Resources Conservation Service, 2009a). The infiltration rate of combination soil groups was calculated from the average of the two soil groups that were mixed (table S6-1).

Till thicknesses were calculated as the difference between land surface and the top of the Elm aquifer. The modified infiltration rates were selected to decrease with greater till thickness, which better accounted for the impermeable character of glacial till. The till thickness intervals used in creating the modified soil groups were set as 0 to $10 \mathrm{ft}$, greater than 10 to $20 \mathrm{ft}$, greater than 20 to $30 \mathrm{ft}$, and greater than $30 \mathrm{ft}$ (table S6-1). A maximum infiltration rate was estimated on the basis of glacial till thickness overlying the Elm aquifer and the range of vertical hydraulic conductivity for glacial till (table 3). Emmons (1990) used a linear decrease in recharge from 7.0 to $0 \mathrm{in} / \mathrm{yr}$ as till thickness increased from 0 to $50 \mathrm{ft}$. The low recharge values coincide with areas where glacial till was thickest. The SWB program also uses a flow-direction algorithm that accumulates recharge that moves towards topographically low areas, resulting in the higher values of recharge.

Land-cover data for 2006 were obtained from the Multi-Resolution Land Characteristics Consortium (2011) as 30-m (98-ft) raster data (fig. 3). The most prevalent land cover was selected for each model cell because about four land-cover raster cells were in each model cell. Most of the model grid had one or two land-cover types as designated by the land-cover raster (Multi-Resolution Land Characteristics Consortium, 2011). Each land cover was assigned values for interception storage in the growing and dormant seasons. The growing season was set as the period from May 1 to September 30. Interception storage values of zero were assigned for the dormant season, and values for the growing season ranged from 0 to 0.11 inch (table S6-2). Land cover and soil group were assigned to every cell in the model, and each combination of land cover and soil group was assigned a curve number and depth of root zone.

The curve number was identical for every soil within the same hydrologic soil group because till thickness has no effect on the curve number. Curve numbers were assigned based on classifications in the National Engineering Handbook (Curve 


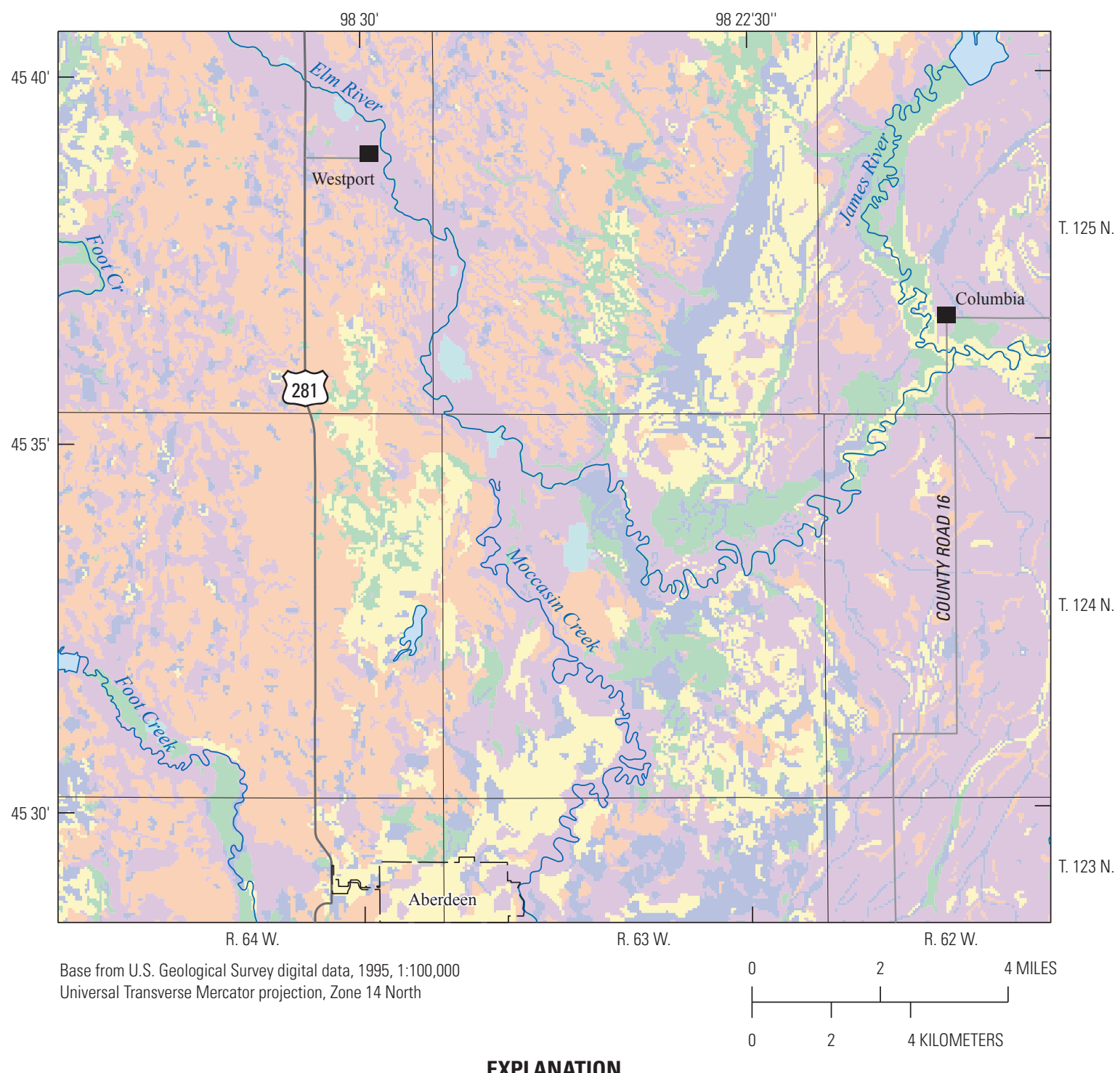

EXPLANATION

\section{Soil type}

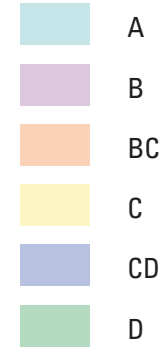

Figure S6-1. Soil type as defined for recharge calculations in soil-water-balance method (based on soil survey data from Natural Resources Conservation Service, 2009a). 
Table S6-2. Interception storage values and depth of root zone assigned by land-cover category.

\begin{tabular}{lcc}
\hline \multicolumn{1}{c}{ Land-cover category } & $\begin{array}{c}\text { Interception } \\
\text { storage, } \\
\text { in inches }\end{array}$ & $\begin{array}{c}\text { Depth of } \\
\text { root zone, } \\
\text { in feet }\end{array}$ \\
\hline Open water & 0.00 & 0.0 \\
Developed, open space & 0.08 & 2.0 \\
Developed, low intensity & 0.08 & 2.0 \\
Developed, medium intensity & 0.06 & 2.0 \\
Developed, high intensity & 0.06 & 2.0 \\
Barren land & 0.00 & 2.0 \\
Deciduous forest & 0.09 & 4.5 \\
Evergreen forest & 0.11 & 5.5 \\
Shrub or scrub & 0.06 & 3.5 \\
Herbaceous grassland & 0.09 & 4.0 \\
Pasture/hay & 0.09 & 4.0 \\
Cultivated crops & 0.09 & 3.5 \\
Woody wetlands & 0.05 & 4.5 \\
Emergent herbaceous wetlands & 0.00 & 2.0 \\
\hline
\end{tabular}

Number Work Group, 2004). Developed land covers were given curve numbers calculated as the average of relevant classifications to the known land covers (for example, gravel roads, paved roads with open ditches, and $1 / 4$-acre residential) (Curve Number Work Group, 2004). Wetland land covers were assigned curve numbers from Westenbroek and others (2010) because the National Engineering Handbook did not include wetlands in the types of land covers discussed.

The root zone depths were assigned as identical for every soil (table S6-2), but varied by land cover using data compiled by Canadell and others (1996) and Westenbroek and others (2010) because data were not sufficient to further constrain the inputs; however, Thornthwaite and Mather (1957) determined that plants typically have deeper roots in sandy soils than in clayey soils (Westenbroek and others, 2010). The SWB program uses available water capacity for each root zone category to calculate the maximum amount of water that the soil can hold in storage (Westenbroek and others, 2010). The Natural Resources Conservation Service soil survey for Brown County contained available water capacity ranges for each horizon in every soil (Natural Resources Conservation Service, 2009b). The soils were lumped according to hydrologic group, so the available water capacity data were averaged to generate one value per hydrologic group. 


\section{Supplement 7. Water-Level Data for Generalized Potentiometric Surface of Elm Aquifer}

Table S7-1. Water-level data for generalized average potentiometric surface of Elm Aquifer (1975-2009).

$[--$, not applicable $]$

\begin{tabular}{|c|c|c|c|c|c|c|c|}
\hline $\begin{array}{c}\text { Site } \\
\text { identifier } \\
\text { (fig. 18) }\end{array}$ & $\begin{array}{c}\text { Station } \\
\text { identification } \\
\text { number }\end{array}$ & Local number & $\begin{array}{c}\text { Earliest } \\
\text { or single } \\
\text { water-level } \\
\text { date }\end{array}$ & $\begin{array}{c}\text { Earliest } \\
\text { or single } \\
\text { water-level }^{\text {altitude }}{ }^{1}\end{array}$ & $\begin{array}{c}\text { Other } \\
\text { identifier }\end{array}$ & $\begin{array}{l}\text { Period of record } \\
\text { for wells with } \\
\text { synoptic } \\
\text { water-level } \\
\text { measurements }\end{array}$ & $\begin{array}{l}\text { Estimated } \\
\text { average } \\
\text { water-level } \\
\text { altitude } \\
(1975-2009)^{1}\end{array}$ \\
\hline 1 & 454010098314402 & 125N64W 3CAA2 & 08/01/1970 & 1,319 & -- & -- & 1,319 \\
\hline 2 & 453949098321601 & 125N64W10BBBB & 06/01/1984 & 1,337 & -- & -- & 1,340 \\
\hline 3 & 453954098310301 & 125N64W02CCBB & 06/05/2009 & 1,318 & PZ6 & 2009 & 1,317 \\
\hline 4 & 453921098294801 & 125N64W12BCCA & $05 / 21 / 2009$ & 1,318 & $\mathrm{PZ1}$ & 2009 & 1,316 \\
\hline 5 & 453944098283801 & 125N64W12AAA & 08/19/1981 & 1,358 & -- & -- & 1,358 \\
\hline 6 & 453904098281901 & 125N63W 7CCA & 08/20/1981 & 1,317 & -- & -- & 1,321 \\
\hline 7 & 453923098271601 & $125 \mathrm{~N} 63 \mathrm{~W} 8 \mathrm{BCB}$ & 06/03/1983 & 1,338 & -- & -- & 1,339 \\
\hline 8 & 453856098263901 & $125 \mathrm{~N} 63 \mathrm{~W} 8 \mathrm{DCCC}$ & 08/01/1955 & 1,334 & -- & -- & 1,333 \\
\hline 9 & 453948098260601 & 125N63W 5DDDD & 08/01/1955 & 1,344 & -- & -- & 1,343 \\
\hline 10 & 454037098245201 & 125N63W04AAAA & 06/07/1977 & 1,323 & $\mathrm{BN}-77 \mathrm{~N}$ & $1977-2009$ & 1,324 \\
\hline 11 & 453853098245201 & 125N63W16AAAA & 06/07/1977 & 1,328 & $\mathrm{BN}-77 \mathrm{M}$ & 1977-2009 & 1,327 \\
\hline 12 & 453837098224001 & 125N64W14ADB & 04/11/1983 & 1,286 & -- & -- & 1,287 \\
\hline 13 & 453957098214101 & 125N63W 1DCC & $10 / 31 / 1983$ & 1,290 & -- & -- & 1,290 \\
\hline 14 & 453800098222002 & 125N63W13CCCC2 & $10 / 11 / 1974$ & 1,291 & MM1 & $1974-85$ & 1,292 \\
\hline 15 & 453734098295201 & 125N64W23DAA & 08/01/1970 & 1,340 & -- & -- & 1,340 \\
\hline 16 & 453911098280201 & 125N63W19CDDD & 06/05/2009 & 1,311 & PZ7 & 2009 & 1,308 \\
\hline 17 & 453616098321201 & 125N64W34BBB & 08/01/1970 & 1,356 & -- & -- & 1,356 \\
\hline 18 & 453635098305701 & $125 \mathrm{~N} 64 \mathrm{~W} 26 \mathrm{CBC}$ & 08/01/1970 & 1,339 & -- & -- & 1,339 \\
\hline 19 & 453622098284201 & 125N64W25DDAD & 06/05/2009 & 1,308 & PZ8 & 2009 & 1,307 \\
\hline 20 & 453620098275801 & 125N63W30CDDD & 09/01/1968 & 1,303 & -- & -- & 1,303 \\
\hline 21 & 453623098271601 & 125N63W29CCCC & 06/07/1977 & 1,330 & $\mathrm{BN}-77 \mathrm{~L}$ & 1977-2009 & 1,336 \\
\hline 22 & 453639098195601 & 125N62W30DAA & 07/01/1951 & 1,282 & -- & -- & 1,276 \\
\hline 23 & 453520098320501 & 124N64W04AAAA1 & $05 / 20 / 1982$ & 1,340 & $\mathrm{BN}-82 \mathrm{E}$ & $1982-2009$ & 1,348 \\
\hline 24 & 453515098280601 & 124N63W06BACA & 07/07/2009 & 1,308 & PZ9 & 2009 & 1,307 \\
\hline 25 & 453508098273101 & 124N63W06ADBB & 06/05/2009 & 1,303 & PZ5 & 2009 & 1,302 \\
\hline 26 & 453457098273301 & 124N63W06DABB & 06/05/2009 & 1,303 & $\mathrm{PZ4}$ & 2009 & 1,302 \\
\hline 27 & 453524098222301 & 125N63W35DDDD & 08/01/1968 & 1,293 & -- & -- & 1,290 \\
\hline 28 & 453438098314501 & 124N64W 3CDC & 08/01/1970 & 1,331 & -- & -- & 1,331 \\
\hline 29 & 453437098272401 & 124N63W06DDBD & 09/19/2005 & 1,300 & -- & -- & 1,297 \\
\hline 30 & 453430098264501 & 124N63W08ABBA & 05/12/2008 & 1,306 & $A-2$ & 2008-09 & 1,301 \\
\hline 31 & 453430098262901 & 124N63W08ABBA & $05 / 12 / 2008$ & 1,307 & $\mathrm{~A}-1$ & 2008-09 & 1,303 \\
\hline 32 & 453436098260101 & 124N63W05DDAD & 07/06/2009 & 1,310 & PZ10 & 2009 & 1,306 \\
\hline 33 & 453424098260101 & 124N63W08AADA & 08/01/2009 & 1,305 & PZ11 & 2009 & 1,304 \\
\hline 34 & 453424098271701 & 124N63W 7AAD & 09/01/1967 & 1,299 & -- & -- & 1,298 \\
\hline
\end{tabular}


Table S7-1. Water-level data for generalized average potentiometric surface of Elm Aquifer (1975-2009).—Continued [--, not applicable]

\begin{tabular}{|c|c|c|c|c|c|c|c|}
\hline $\begin{array}{c}\text { Site } \\
\text { identifier } \\
\text { (fig. 18) }\end{array}$ & $\begin{array}{c}\text { Station } \\
\text { identification } \\
\text { number }\end{array}$ & Local number & $\begin{array}{c}\text { Earliest } \\
\text { or single } \\
\text { water-level } \\
\text { date }\end{array}$ & $\begin{array}{c}\text { Earliest } \\
\text { or single } \\
\text { water-level } \\
\text { altitude }^{1}\end{array}$ & $\begin{array}{c}\text { Other } \\
\text { identifier }\end{array}$ & $\begin{array}{l}\text { Period of record } \\
\text { for wells with } \\
\text { synoptic } \\
\text { water-level } \\
\text { measurements }\end{array}$ & $\begin{array}{c}\text { Estimated } \\
\text { average } \\
\text { water-level } \\
\text { altitude } \\
(1975-2009)^{1}\end{array}$ \\
\hline 35 & 453414098265701 & 124N63W08BCAA & $12 / 03 / 2004$ & 1,303 & -- & -- & 1,300 \\
\hline 36 & 453410098264601 & 124N63W08BDAC & $12 / 02 / 2004$ & 1,304 & -- & -- & 1,301 \\
\hline 37 & 453359098263801 & 124N63W08AADD & $12 / 02 / 2004$ & 1,304 & -- & -- & 1,300 \\
\hline 38 & 453351098264501 & $124 \mathrm{~N} 63 \mathrm{~W} 8 \mathrm{DAC}$ & $10 / 30 / 1998$ & 1,307 & -- & -- & 1,306 \\
\hline 39 & 453351098261701 & 124N63W 8DACC & $10 / 30 / 1998$ & 1,306 & -- & -- & 1,305 \\
\hline 40 & 453439098243201 & 124N63W 3CCAB & $09 / 01 / 1967$ & 1,300 & -- & -- & 1,299 \\
\hline 41 & 453428098194202 & 124N62W08BBBB2 & $06 / 09 / 1982$ & 1,283 & $\mathrm{BN}-82 \mathrm{~K}$ & 1982-2009 & 1,293 \\
\hline 42 & 453346098343101 & $124 \mathrm{~N} 64 \mathrm{~W} 8 \mathrm{CCC}$ & 08/01/1970 & 1,361 & -- & -- & 1,361 \\
\hline 43 & 453340098311001 & 124N64W10DDD & $08 / 01 / 2007$ & 1,338 & R0-00-41 & -- & 1,337 \\
\hline 44 & 453320098305902 & 124N64W15ADD2 & $08 / 01 / 1970$ & 1,328 & -- & -- & 1,328 \\
\hline 45 & 453341098255801 & 124N63W16BBCB & $10 / 30 / 1998$ & 1,306 & -- & -- & 1,305 \\
\hline 46 & 453336098252401 & 124N63W16BAAC & $10 / 30 / 1998$ & 1,308 & -- & -- & 1,307 \\
\hline 47 & 453345098243901 & 124N63W10CCC & $02 / 01 / 1967$ & 1,296 & -- & -- & 1,295 \\
\hline 48 & 453312098244401 & $124 \mathrm{~N} 63 \mathrm{~W} 15 \mathrm{CBBB}$ & $10 / 05 / 1974$ & 1,296 & MM3 & $1974-85$ & 1,296 \\
\hline 49 & 453402098183201 & 124N62W08ADDD & $10 / 09 / 1974$ & 1,287 & MM2 & $1974-85$ & 1,290 \\
\hline 50 & 453254098340401 & 124N64W17CDD & $07 / 27 / 1982$ & 1,349 & -- & -- & 1,354 \\
\hline 51 & 453254098304901 & 124N64W14CCC & $08 / 01 / 1970$ & 1,326 & -- & -- & 1,326 \\
\hline 52 & 453254098301201 & 124N64W14DCC & $08 / 01 / 1970$ & 1,323 & -- & -- & 1,323 \\
\hline 53 & 453246098294501 & 124N64W23AAAA & $07 / 30 / 2007$ & 1,326 & $\mathrm{R} 2-00-42$ & 2007-2009 & 1,326 \\
\hline 54 & 453247098260103 & 124N63W17DDDD3 & 08/23/1999 & 1,305 & MM5 & 1999-2009 & 1,307 \\
\hline 55 & 453246098243901 & 124N63W22BBB & $07 / 01 / 1955$ & 1,294 & -- & -- & 1,294 \\
\hline 56 & 453200098343901 & 124N64W20CCCB & $08 / 01 / 2007$ & 1,350 & $\mathrm{R} 2-00-51$ & 2007-2009 & 1,347 \\
\hline 57 & 453155098330801 & 124N64W28BBA & $08 / 01 / 1970$ & 1,329 & -- & -- & 1,329 \\
\hline 58 & 453203098323801 & 124N64W21DCCD & 09/30/1987 & 1,329 & -- & -- & 1,332 \\
\hline 59 & 453202098320301 & 124N64W22CCC & $11 / 16 / 1982$ & 1,322 & -- & -- & 1,328 \\
\hline 60 & 453136098320302 & 124N64W27BCC2 & 08/01/1970 & 1,324 & -- & -- & 1,324 \\
\hline 61 & 453159098282401 & 124N63W19CCCC & $09 / 01 / 1967$ & 1,305 & -- & -- & 1,304 \\
\hline 62 & 453154098255301 & 124N63W28BBB & $07 / 01 / 1955$ & 1,296 & -- & -- & 1,292 \\
\hline 63 & 453214098232501 & 124N63W23CBC & 07/01/1955 & 1,292 & -- & -- & 1,292 \\
\hline 64 & 453153098232901 & 124N63W23CCCD & $07 / 31 / 2007$ & 1,301 & -- & -- & 1,299 \\
\hline 65 & 453147098222101 & 124N63W26AAD & $09 / 01 / 1967$ & 1,294 & -- & -- & 1,295 \\
\hline 66 & 453103098341301 & 124N64W32BAB & 08/01/1970 & 1,321 & -- & -- & 1,321 \\
\hline 67 & 453109098332702 & 124N64W29DDD2 & $08 / 01 / 1970$ & 1,324 & -- & -- & 1,324 \\
\hline 68 & 453103098310801 & 124N64W34AAB & $08 / 01 / 1970$ & 1,320 & -- & -- & 1,320 \\
\hline 69 & 453131098294203 & 124N64W26DAAA3 & $08 / 01 / 1970$ & 1,312 & -- & -- & 1,311 \\
\hline 70 & 453109098294501 & 124N64W26DDD & $08 / 01 / 1970$ & 1,311 & -- & -- & 1,313 \\
\hline 71 & 453116098292601 & 124N64W25CCA & $08 / 01 / 1970$ & 1,306 & -- & -- & 1,305 \\
\hline 72 & 453134098271701 & 124N63W30ADD & $07 / 01 / 1955$ & 1,298 & -- & -- & 1,294 \\
\hline
\end{tabular}


Table S7-1. Water-level data for generalized average potentiometric surface of Elm Aquifer (1975-2009)._Continued $[--$, not applicable $]$

\begin{tabular}{|c|c|c|c|c|c|c|c|}
\hline $\begin{array}{c}\text { Site } \\
\text { identifier } \\
\text { (fig. 18) }\end{array}$ & $\begin{array}{c}\text { Station } \\
\text { identification } \\
\text { number }\end{array}$ & Local number & $\begin{array}{c}\text { Earliest } \\
\text { or single } \\
\text { water-level } \\
\text { date }\end{array}$ & $\begin{array}{c}\text { Earliest } \\
\text { or single } \\
\text { water-level } \\
\text { altitude }^{1}\end{array}$ & $\begin{array}{c}\text { Other } \\
\text { identifier }\end{array}$ & $\begin{array}{l}\text { Period of record } \\
\text { for wells with } \\
\text { synoptic } \\
\text { water-level } \\
\text { measurements }\end{array}$ & $\begin{array}{c}\text { Estimated } \\
\text { average } \\
\text { water-level } \\
\text { altitude } \\
(1975-2009)^{1}\end{array}$ \\
\hline 73 & 453103098255701 & 124N63W28CCCC & 05/20/1982 & 1,297 & $\mathrm{BN}-82 \mathrm{~F}$ & 1982-2009 & 1,295 \\
\hline 74 & 453128098243901 & 124N63W27CBB & 07/01/1955 & 1,290 & -- & -- & 1,286 \\
\hline 75 & 453054098243601 & 124N63W34BB & 06/02/1983 & 1,281 & -- & -- & 1,283 \\
\hline 76 & 453055098233501 & 124N63W34AAD & 07/01/1955 & 1,291 & -- & -- & 1,291 \\
\hline 77 & 453105098183002 & $124 \mathrm{~N} 62 \mathrm{~W} 28 \mathrm{CCCC} 2$ & 08/01/1967 & 1,279 & -- & -- & 1,274 \\
\hline 78 & 452950098321502 & 123N64W 4ADDC2 & 03/01/1969 & 1,307 & -- & -- & 1,307 \\
\hline 79 & 452923098313301 & 123N64W 3CDDD & 03/01/1926 & 1,313 & -- & -- & 1,309 \\
\hline 80 & 453016098293601 & 124N64W36CCDB & $07 / 31 / 2007$ & 1,309 & -- & -- & 1,305 \\
\hline 81 & 452955098271401 & 123N63W 6ADAD & 06/01/1949 & 1,292 & -- & -- & 1,291 \\
\hline 82 & 453012098255602 & 124N63W33CCCC2 & 05/01/1956 & 1,288 & -- & -- & 1,284 \\
\hline 83 & 452948098233201 & 123N63W 3ADDD & 06/01/1949 & 1,294 & -- & -- & 1,290 \\
\hline 84 & 452846098295401 & 123N64W11DAC & 06/01/1949 & 1,303 & -- & -- & 1,301 \\
\hline 85 & 452851098282101 & $123 \mathrm{~N} 63 \mathrm{~W} 7 \mathrm{CBB}$ & 07/01/1949 & 1,292 & -- & -- & 1,291 \\
\hline 86 & 452915098271501 & 123N63W08BBBB & 09/06/1977 & 1,284 & $\mathrm{BN}-77 \mathrm{~V}$ & 1977-2009 & 1,293 \\
\hline 87 & 452917098255301 & $123 \mathrm{~N} 63 \mathrm{~W} 9 \mathrm{BBB}$ & 06/01/1949 & 1,286 & -- & -- & 1,284 \\
\hline 88 & 452924098244902 & 123N63W 4DDD2 & 06/01/1949 & 1,293 & -- & -- & 1,287 \\
\hline 89 & 452830098230101 & 123N63W11CDDC & 07/01/1968 & 1,291 & -- & -- & 1,288 \\
\hline 90 & 452948098194301 & $123 \mathrm{~N} 62 \mathrm{~W} 5 \mathrm{BCC}$ & 06/01/1949 & 1,284 & -- & -- & 1,280 \\
\hline 91 & 452928098194401 & $123 \mathrm{~N} 62 \mathrm{~W} 05 \mathrm{CBCC}$ & 10/09/1974 & 1,281 & MM4 & $1974-85$ & 1,283 \\
\hline
\end{tabular}

${ }^{1}$ Datum is North American Vertical Datum of 1988.

Publishing support provided by:

Rolla Publishing Service Center

For more information concerning this publication, contact:

Director, USGS South Dakota Water Science Center 1608 Mt. View Road

Rapid City, SD 57702

(605) 394-3200

Or visit the South Dakota Water Science Center Web site at: http://sd.water.usgs.gov 


\section{Back cover.}

Top left: Installing temperature probe along the Elm River.

Top right: Surveying altitude of a piezometer completed in the Elm aquifer. Lower bottom: Collecting direct-current electrical resistivity data. 
